FACULDADE DE FILOSOFIA, LETRAS E CIÊNCIAS HUMANAS

DEPARTAMENTO DE LETRAS CLÁSSICAS E VERNÁCULAS

PROGRAMA DE PÓS-GRADUAÇÃO EM LETRAS CLÁSSICAS

\title{
Écfrase e Evidência nas Letras Latinas: Doutrina e Práxis
}

\author{
Melina Rodolpho
}

Dissertação apresentada ao Programa de PósGraduação em Letras Clássicas do Departamento de Letras Clássicas e Vernáculas da Faculdade de Filosofia, Letras e Ciências Humanas da Universidade de São Paulo, para obtenção do título de mestre.

Orientador: Prof. Dr. Paulo Martins

Exemplar revisado - "de acordo com o Prof.

Orientador Dr. Paulo Martins" 
Nome: RodolPHO, Melina

Título: Écfrase e Evidência nas Letras Latinas: Doutrina e Práxis

Dissertação apresentada ao Programa de PósGraduação em Letras Clássicas do Departamento de Letras Clássicas e Vernáculas da Faculdade de Filosofia, Letras e Ciências Humanas da Universidade de São Paulo, para obtenção do título de mestre.

Aprovado em:

Banca Examinadora 


\title{
RESUMO
}

A finalidade da pesquisa é estudar a écfrase, identificada como descrição na retórica latina, e a evidência, com a qual geralmente é confundida A écfrase contribui para provocar o efeito de visualização do discurso verbal, portanto, o estudo das teorias antigas que aproximam o meio verbal do visual serve como base para sua compreensão. Há certa profusão de nomes para o processo ecfrástico, gerando confusão ao se tentar estabelecer os limites e diferenças de cada procedimento. O processo imaginativo, teorizado por Aristóteles como fantasia, é parte fundamental para compreender como se manifesta a evidência (ou ainda "enargia"). Além da teoria, analisamos a aplicação dos conceitos estudados a partir de alguns exemplos do gênero épico e historiográfico, realizando também a tradução de tais textos.

PALAVRAS-CHAVE: Écfrase; Descrição; Evidência; Enargia; Fantasia.

\begin{abstract}
The purpose of this paper is to study ekphrasis, known as description in Latin Rhetoric, which is normally confused with euidentia. The ekphrasis contributes to cause a visualization's effect of the verbal speech. Therefore, the study of ancient theories, which approach the verbal language to the visual, works as basis for its comprehension. There is some profusion of names for the ekphrastic process, leading to confusion when we try to establish the limits and differences of each procedure. The imaginative process, theorized by Aristotle as phantasia, is a fundamental part to understand how the euidentia (or enargeia) works. Beyond the theory, we analyze the application of the concepts from some examples of the epic and historiographical genres, also translating these texts.
\end{abstract}

KEYWORDS: Ekphrasis; Description; Euidentia; Enargeia; Phantasia. 


\section{Agradecimentos}

Agradeço ao Professor Dr. Paulo Martins, meu orientador, pela colaboração, paciência e incentivo e também por me direcionar ao estudo de um tema primoroso.

Devo sinceros agradecimentos aos Professores Doutores João Angelo Oliva Neto e Roberto Bolzani Filho pelas importantes indicações e correções oferecidas no exame de qualificação e a todos os professores de minha graduação e pós-graduação que contribuíram para minha formação acadêmica.

Ao Conselho Nacional de Desenvolvimento Científico e Tecnológico (CNPq) que concedeu a bolsa de mestrado, fundamental para a realização da pesquisa.

A todos os amigos que pacientemente me ouviram falar (muito) da écfrase.

Por fim, especial agradecimento às pessoas mais queridas: minha mãe, Lindinalva, a quem devo minha alfabetização, e meus irmãos Anderson, Osmar e Renato, que ofereceram apoio em todos os sentidos enquanto cursava a faculdade e o mestrado. 
SUMÁRIO

$\begin{array}{ll}\text { RESUMO } & 3\end{array}$

$\begin{array}{ll}\text { Abstract } & 3\end{array}$

AGRADECIMENTOS

SUMÁRIO

$\begin{array}{lr}\text { INTRODUÇÃOO } & 8\end{array}$

I. TEORIZAÇÃo E HISTÓRICO DOS CONCEITOS

I.1. Amplificação $\quad 21$

$\begin{array}{ll}\text { Aristóteles } & 21 \\ \text { Cícero } & 21\end{array}$

Cícero 22

$\begin{array}{ll}\text { Quintiliano } & 28 \\ & 28\end{array}$

Anônimo - Do Sublime 31

I.2. Metáfora

Aristóteles $\quad 32$

Cícero $\quad 37$

$\begin{array}{ll}\text { Quintiliano } & 38\end{array}$

I.3. Fantasia

Platão $\quad 45$

Aristóteles $\quad 49$

Os Estóicos $\quad 54$

Sexto Empírico $\quad 58$

$\begin{array}{ll}\text { Cícero } & 73\end{array}$

Anônimo - Do Sublime $\quad 82$

I.4. Enargia/ Evidência $\quad 86$

Cícero $\quad 86$

$\begin{array}{lr}\text { Quintiliano } & 86\end{array}$

Outros Retores Latinos $\quad 93$

I.5. Hipotipose

Quintiliano $\quad 95$

Progymnásmata $\quad 97$

Outros Retores Latinos $\quad 98$

I.6. Écfrase/ Descrição $\quad 98$

$\begin{array}{lr}\text { Progymnásmata } & 98\end{array}$

$\begin{array}{lr}\text { Outros Retores Latinos } & 104\end{array}$ 
$\begin{array}{ll}\text { II. SiSTEMATIZAÇÃO DOS CONCEITOS } & 107\end{array}$

$\begin{array}{ll}\text { II.1. Écfrase/ Descrição } & 108\end{array}$

$\begin{array}{ll}\text { II.2. Enargia/ Evidência } & 114\end{array}$

$\begin{array}{lr}\text { II.3. Fantasia } & 120\end{array}$

$\begin{array}{lr}\text { III. APLICAÇÃO DOS PROCEDIMENTOS } & 125\end{array}$

$\begin{array}{lr}\text { III.1. Eneida } & 125\end{array}$

$\begin{array}{lr}\text { As pinturas do templo } & 125\end{array}$

$\begin{array}{ll}\text { Laocoonte } & 131\end{array}$

$\begin{array}{ll}\text { Clâmide } & 137\end{array}$

As portas do templo de Apolo $\quad 138$

$\begin{array}{ll}\text { Escudo de Turno } & 140\end{array}$

O escudo de Eneias $\quad 142$

O cinto de Palante 159

III.2. Poema 64 de Catulo 161

$\begin{array}{lr}\text { III.3. Salústio } & 173\end{array}$

III.3.1. Guerra de Jugurta 173

III.3.2. Conjuração de Catilina 179

III.4. Suetônio $\quad \mathbf{1 9 0}$

O Divino Júlio - Livro I do De Vita Caesarum 190

$\begin{array}{lr}\text { CONSIDERAÇÕES FINAIS } & 205\end{array}$

$\begin{array}{lr}\text { BIBLIOGRAFIA } & 207\end{array}$

$\begin{array}{lr}\text { REFERENCIAS ANTIGAS } & \mathbf{2 0 7}\end{array}$

REFERÊNCIAS MODERNAS 


\section{Introdução}

A poesia antiga seguia não apenas os critérios da teoria poética, como também utilizava recursos retóricos na sua composição. É possível estabelecer certa relação entre os discursos retórico e poético a partir, por exemplo, do tom adotado (elevado/ baixo), bem como a adoção de ornamentos (tropos e figuras), gêneros e funções retóricas também aplicadas à poesia. Todo texto tem um objetivo e, não raro, encontrase inserido na poesia uma das três funções retóricas, a saber: docere, mouere e delectare. Portanto, se os fins são os mesmos, há lógica que os meios também o sejam.

Os procedimentos estudados na presente pesquisa inserem-se dentre os recursos que servem tanto à retórica como à poética, mas o que nos interessa é estudá-los sob o prisma dos recursos que permitem produzir imagens verbais; entramos, portanto, em outra questão muito difundida na Antiguidade: trata-se da relação entre as artes verbais e as visuais.

Adotaremos inicialmente a terminologia écfrase, cujo termo grego é ékphrasis, equivalendo à descrição latina, descriptio, e da mesma maneira, adotamos enargia para enárgeia e evidência para euidentia como correspondentes; no entanto, no decorrer desse estudo, verificaremos que as definições e nomeação dos conceitos não são tão exatas.

A écfrase/ descrição consiste no processo descritivo detalhado por meio do qual se pode produzir um "quadro" do objeto da descrição; temos então a enargia/ evidência, que pode ser considerada figura de pensamento cuja finalidade é conferir vivacidade à imagem verbal. A écfrase não é o único procedimento capaz de gerar essa enargia, conforme se verá; contudo, nos desperta o interesse em razão de sua história, pois é frequentemente associada à construção de imagens que, por sua vez, representam objetos inexistentes de maneira absolutamente crível.

A enargia/ evidência como figura de pensamento está estruturada retoricamente na elocução. Sabe-se que a elocução é uma etapa importante da composição, pois nela se modela o texto de acordo com o público a que se pretende atingir e está, portanto, relacionada à persuasão desse público. Logo, a elocução serve a outras etapas da composição retórica - a invenção e a disposição -, da mesma maneira que a poesia deve estruturar suas partes para resultar num todo coerente, o discurso retórico também deve fazê-lo; assim, as diferentes fases do discurso não são estanques. 
Compreende-se que a écfrase e a enargia, ainda que ornatos da elocução, sirvam também aos propósitos da invenção e da disposição - etapas que, logicamente, faziam parte do trabalho da composição poética. Portanto, supõe-se que a evidência não esteja inserida como mero ornamento, mas tenha uma finalidade própria dentro do conjunto.

Ao iniciar a pesquisa, tínhamos em vista diferenciar a écfrase da evidência, já que são geralmente confundidas; justifica-se desse modo a aparente incoerência do título desse trabalho que traz a terminologia grega e latina para conceitos que, na realidade, são distintos. Seria lógico colocar os pares "écfrase e enargia" ou "descrição e evidência", no entanto, preferi manter o título inicial em razão justamente da dificuldade que se apresenta ao determinar a nomenclatura e traçar os limites de tais procedimentos - fato que, como discutiremos durante todo esse estudo, é bastante recorrente. 


\section{Teorização e histórico dos conceitos}

De acordo com a doutrina aristotélica, no livro I de sua Retórica, há três tipos de gêneros retóricos: o deliberativo, o epidítico, o judiciário. Em linhas gerais, o deliberativo constitui-se do conselho ou da dissuasão, cujos temas principais são basicamente: finanças, guerra e paz, defesa nacional, importações e exportações e legislação. O tempo que lhe é apropriado, portanto, é o futuro, pois se discute acerca das decisões; sua finalidade é aconselhar o conveniente e desaconselhar o prejudicial, para que se alcancem os objetivos por meio de ações convenientes e boas. Ao tratar dos graus de conveniência, Aristóteles faz uma afirmação acerca da visão que nos interessa, em 1364a": "Coisas cuja superioridade é mais desejável a mais bela são também preferíveis; por exemplo: é preferível ter acuidade visual a ter a olfativa, pois a visão é melhor do que o olfato."

O epidítico trata do elogio ou da censura que incite na virtude ou no vício. Há dois tipos: o elogio, que discorre acerca das virtudes de um indivíduo, e o encômio, que se refere as suas obras. O presente é o tempo correspondente, pois tais discursos são feitos a respeito de pessoas ou acontecimentos atuais; ainda que se utilizem argumentos do passado e conjecturas sobre o futuro, sua finalidade é tratar do belo e do feio. Devem-se utilizar muitos meios de amplificação (auxésis) neste gênero, procedimento do qual trataremos adiante, para que o elogiado pareça melhor do que os virtuosos. A censura constitui-se dos contrários do elogio.

O judiciário diz respeito ao julgamento, onde estão presentes a acusação e a defesa, o tempo deste gênero é o passado, pois o julgamento se refere aos fatos já ocorridos; seu objetivo é tratar do justo e do injusto. Ainda no primeiro livro, no capítulo 11 da Retórica, Aristóteles elenca uma série de fatos que agradam às pessoas, estabelecendo uma relação temática entre temas aprazíveis e a retórica judicial. A vingança e a vitória, por exemplo, são agradáveis, e, embora uma causa judicial seja penosa, pois é imposta por necessidade, é igualmente aprazível visto que por meio dela a vitória é possível.

Nesse contexto que Aristóteles apresenta um conceito que nos interessa bastante: a fantasia. O prazer é certo movimento da alma, como a fantasia (da qual trataremos em

\footnotetext{
${ }^{1}$ Para todas as citações da Retórica adotamos a tradução de Manuel Alexandre Júnior; Paulo Farmhouse Alberto \& Abel do Nascimento Pena. Lisboa: Casa da Moeda. 1998.
} 
breve), que produz o agradável; resulta disso certo prazer na sensação de lembrar o passado, sentir o presente e esperar o futuro.

A classificação dos gêneros retóricos proposta por Aristóteles perdura na tradição latina conforme observamos na Retórica a Herênio, I, 2, onde temos a mesma classificação para os gêneros de causas ${ }^{2}$ :

Tria genera sunt causarum, quae recipere debet orator: demonstratiuum, deliberatiuum, iudiciale. Demonstratiuum est, quod tribuitur in alicuius certae personae laudem uel uitoperationem. Deliberatiuum est in consulatione, quod habet in se suasionem et dissuasionem. Iudiciale est, quod positum est in controuersia et quod habet accusationem aut petitionem cum defensione.

Três são os gêneros de causas de que o orador deve incumbir-se: o demonstrativo, o deliberativo e o judiciário. $\mathrm{O}$ demonstrativo destinase ao elogio ou vitupério de determinada pessoa. O deliberativo efetiva-se na discussão, que inclui aconselhar e desaconselhar. $\mathrm{O}$ judiciário contempla a controvérsia legal e comporta acusação pública ou reclamação em juízo com defesa.

A respeito do gênero demonstrativo, equivalente ao epidítico, o tratado retoma sua explicação no livro III, 10, o elogio ou vitupério pode ser de três tipos: coisas externas, corpo e ânimo. As coisas externas são aquelas que advêm da fortuna como a ascendência, educação, riqueza, poder, glória, cidadania, amizades, etc, e seus contrários. O corpo refere-se ao que a natureza atribuiu como a rapidez, a força, a beleza, a saúde e seus contrários. O ânimo inclui aspectos da deliberação e reflexão como prudência, justiça, coragem, modéstia e seus contrários. No §15, não é necessário adotar sempre os três tipos de elogio/ vitupério no discurso, pois devem ser escolhidas as partes que sejam mais consistentes. Recomenda-se concluir com enumeração e amplificações frequentes e breves junto aos lugares-comuns.

A exemplo do que ocorre nos gêneros poéticos, os discursos retóricos possuem elementos em comum e, segundo a necessidade, um discurso pode estar inserido no outro. Inicialmente, acreditamos que a écfrase ou a evidência são tipicamente utilizadas no discurso epidítico, fato que discutiremos no estudo de exemplos de tais procedimentos.

\footnotetext{
${ }^{2}$ Para todas as citações da Retórica a Herênio adotamos a tradução de Adriana Seabra \& A. P. Celestino Faria. São Paulo: Hedra. 2005.
} 
O gênero epidítico adota como meio para louvar ou vituperar um indivíduo ou um grupo de pessoas (como uma nação) a descrição do aspecto físico e moral; assim, cria-se um retrato de sua imagem juntamente com a construção de um éthos. Podemos lembrar aqui um tipo de figura proposta por Quintiliano, a etopeia, em IX, II,58:

Imitatio morum alienorum, quae ethopoiía uel, ut alii malunt, mimesis dicitur, iam inter leniores adfectus numerari potest [...].

A imitação dos costumes dos outros que uns chamam ethopoiía ou, como outros preferem, mímesis, já pode ser numerada entre os afetos mais brandos $[\ldots]^{3}$.

Hermógenes (II d.C.), teórico da Segunda Sofística, em seus Progymnásmata, §20-22, trata da etopeia como a imitação do caráter de uma personagem; tal imitação pode ser moral, emotiva ou mesmo mista. Aftônio (IV ou V d.C.) - outro autor dos Progymnásmata - afirma ser a etopeia de três tipos: eidolopeía, prosopopeía e ethopeía, em §34-36. A ethopeía contém uma personagem conhecida, inventando-se apenas seu caráter; a eidolopeía contém uma personagem conhecida que já está morta e, por fim, a prosopopeía ocorre quando se inventa a personagem e seu caráter, personificando um objeto inanimado.

Mais adiante nos deteremos nas particularidades das figuras aqui estudadas, por ora, pode-se dizer que a evidência consiste também nessa prática do retrato, pois permite ao leitor/ ouvinte visualizar um retrato do objeto detalhado. A écfrase também se insere nesse discurso, uma vez que é um método da amplificação; no entanto, o discurso ganha tamanha dimensão, que combina a descrição com a narração. Embora possam se apresentar como digressões na estrutura do texto, são fundamentais para corroborar o propósito do autor, pois ambas operam a amplificação, que, por sua vez, constitui um recurso patético da argumentação, comovendo e deleitando o público de modo a tornar o discurso mais verossímil.

Esboçamos anteriormente uma breve definição da écfrase e da evidência e, embora seu tratamento seja retórico, a teoria retórica serve também à poesia. Ainda que não sejam diretamente mencionados os termos écfrase e evidência nos mais conhecidos tratados de poética da Antiguidade, observa-se a relação entre poeta/pintor ou escultor e

\footnotetext{
${ }^{3}$ Tradução nossa.
} 
poesia/pintura ou escultura. A relação entre o aspecto visual e verbal é muito recorrente entre as diversas filosofias da Antiguidade; por essa razão, procuraremos estabelecer um quadro que demonstre as idéias que contribuem para a compreensão dos recursos aqui estudados.

Na doutrina de Platão (427-347 a.C.), em diversos diálogos, encontramos importantes proposições a respeito da visão e das artes visuais; também encontramos a definição de phantasía, "fantasia" em português. Embora o termo seja traduzido de diferentes maneiras, em conformidade com a doutrina seguida por cada tratado, preferimos adotar a transliteração do mesmo, uma vez que sua acepção em português também comporta a diversidade semântica da palavra de origem ${ }^{4}$.

No Sofista ${ }^{5}$, em 234b - 236c, Platão discursa contra o sofista, afirmando que o pintor tem a capacidade de enganar os jovens com sua arte quando mostrada à distância, pois parecerão perfeitas e terão o nome das coisas reais, e o mesmo se pode fazer com as palavras. Com as palavras é possível produzir imagens verbais (eídola legómena 234c) de todas as coisas. Dessa maneira, os jovens, ainda não conhecedores da verdade, são convencidos de que tais imagens são verdadeiras. Entretanto, as pessoas mais velhas, em razão de sua experiência, aprendem a confiar apenas naquilo que é real, mudando suas opiniões; deste modo, o que era grande parecerá pequeno, o que era fácil parecerá difícil, e assim todas as verdades aparentes serão alteradas.

O sofista utiliza a arte de fazer imagem (eidolopoiikèn técnen - 235b) para imitar a realidade, mas ele não é possuidor do conhecimento verdadeiro acerca de tais coisas; por essa razão, o sofista não é confiável.

Há duas classes de imitação: a icástica (téknen eikastikèn - 235d) e a fantástica (téknen phantastikèn - 236c). A icástica segue as proporções características do original em extensão, largura, profundidade e cores, produzindo, portanto, imagens semelhantes ao objeto imitado - eikón. Nos grandes trabalhos, tais como a escultura e a pintura, contudo, não é possível reproduzir as proporções verdadeiras das formas, pois as partes superiores pareceriam menores e as partes inferiores pareceriam grandes, pois a uma vemos à distância, a outra, de perto e consequentemente os artistas abandonam a

\footnotetext{
${ }^{4}$ Algumas acepções para "fantasia" extraídas do Houaiss - Grande Dicionário da Língua Portuguesa: 1 faculdade de imaginar, de criar pela imaginação; 2 obra criada pela imaginação; 3 fig. coisa puramente ideal ou ficcional, sem ligação estreita e imediata com a realidade [...]; 7 psic. atividade representativa com certo grau de criação, cujos conteúdos são determinados por idéias súbitas e por lembranças modificadas ou enfraquecidas de objetos, acontecimentos e situações, inclusive sua significação emocional [...]; etim. lat. phantasìa,ae 'visão, imaginação, aparência, sombra, fantasma, sonho, idéia, concepção'[...].

${ }^{5}$ Sophist. In: Plato.Trad. Harold N. Fowler. London: The Loeb Classical Library. 1952, vol. VII.
} 
verdade e dão às figuras não as proporções do original, mas aquelas que conferem beleza a elas. Nesse caso, temos a imitação fantástica, que é produtora de fantasma phántasma, não de imagem (eikón).

Portanto, para que a cópia pareça bela, o artista adapta as proporções da obra pensando na localização desta e na posição do espectador; as verdadeiras proporções são substituídas por aquelas que transmitem a impressão de verdade, dada a distância em que é vista. Os preceitos platônicos condenam a atitude dos artistas que produzem imagens falsas, contudo, considerando-se os princípios de unidade e verossimilhança, a imitação fantástica é necessária para produzir a imagem apropriada.

Dionísio de Halicarnasso (I a.C.) em seu estudo sobre os oradores compara Lísias e Isócrates (Isocrates, 11): o primeiro é mais conciso, simples e mais convicente em criar a ilusão da verdade (eikasten); ao passo que o outro é superior na amplificação, mais elaborado e habilidoso na técnica. Observamos aqui a reiteração do caráter icástico tratado por Platão no campo da oratória, visto que alguns oradores empregam esse estilo de representação, outros, no entanto, aproximam-se mais da fantástica.

Em Parmênides ${ }^{6}, 165 \mathrm{a}-\mathrm{d}$, a distância entre o espectador e a obra é um aspecto essencial para sua execução. Ao tratar da concepção de quantidade feita pela mente (têi dianoíai - 165a/ b), Platão compara esse processo com a pintura - as coisas contidas na pintura aparentam ser apenas uma quando vistas a certa distância, porém, aproximandose da pintura, é possível perceber que são várias e distintas. Temos nesse contexto a técnica da skiagraphía, pintura com sombra, que produz um efeito à distância contribuindo para produção da imagem que, vista de perto, contudo, perde tal efeito.

Em Filebo ${ }^{7}, 38 b-41$ a, a opinião forma-se a partir da memória e da percepção ${ }^{8}$ (ek mnémes te kaì aisthéseos dóxa). Ele afirma que a alma é como um livro (38e), pois a memória se une aos sentidos, as sensações conectadas aos respectivos sentidos parecem quase escrever palavras na alma e isso produz opiniões verdadeiras ou falsas (39b); é como se houvesse um pintor na alma que pinta quadros para ilustrar as palavras. Isso ocorre quando um homem recebe da visão, ou de algum outro sentido, as opiniões e declarações do momento e detém na mente as imagens de tais opiniões e declarações. As imagens das opiniões verdadeiras são verdadeiras e, das falsas, são falsas. Essa experiência é inevitável em relação ao presente e ao passado, mas não em relação ao

\footnotetext{
${ }^{6}$ Parmenides. In: Plato. Trad. Harold N. Fowler. 1992, vol. IV.

${ }^{7}$ Philebus. In: Plato. Trad. Harold N. Fowler. London: The Loeb Classical Library. 1995, vol. VIII.

8 Adotei aqui a tradução "percepção" para o termo aisthesis, no entanto, pode também ser traduzido como "sensação".
} 
futuro: o prazer e a dor que pertencem à alma vêm antes do prazer e da dor do corpo. Portanto, o prazer e a dor antecipados se referem ao futuro, ainda que sejam falsos, são imitações dos verdadeiros, produzidas com base nesses quadros que já estão presentes em nossas almas.

Na Poética de Aristóteles (384-322 a.C.), a comparação com a pintura ocorre em diversas passagens ${ }^{9}$ :

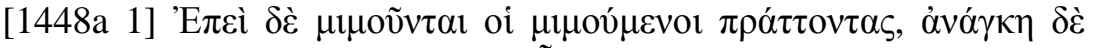

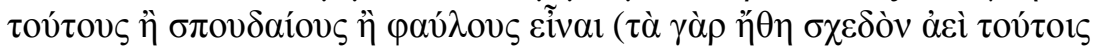

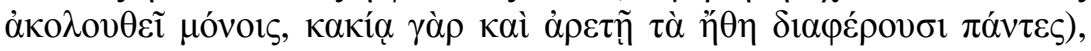

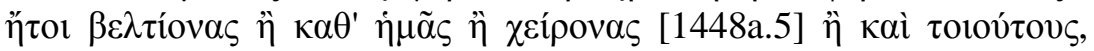

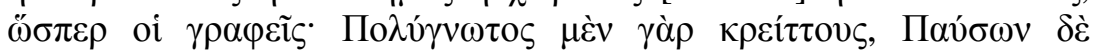

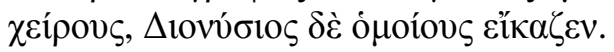

Mas, como os imitadores imitam homens que praticam alguma ação, e estes, necessariamente, são indivíduos de elevada ou de baixa índole (porque a variedade dos caracteres só se encontra nestas diferenças [e, quanto a caráter, todos os homens se distinguem pelo vício ou pela virtude]), necessariamente também sucederá que os poetas imitam homens melhores, piores ou iguais a nós, como o fazem os pintores: Polignoto representava os homens superiores; Páuson, inferiores; Dionísio representava-os semelhantes a nós. [...] (II, 1448a)

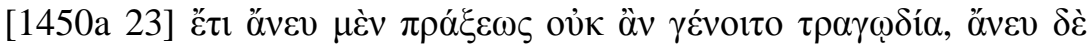

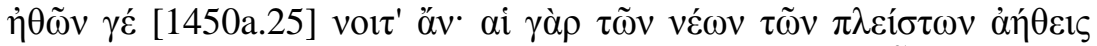

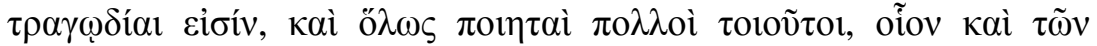

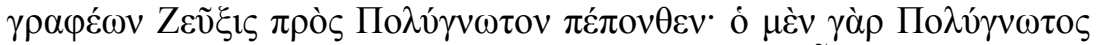

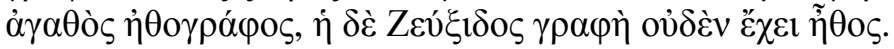

Sem ação não poderia haver Tragédia, mas poderia havê-la sem caracteres. As Tragédias da maior parte dos modernos não têm caracteres, e, em geral, há muitos poetas desta espécie. Também, entre os pintores, assim é Zêuxis ${ }^{10}$ comparado com Polignoto, porque Polignoto é excelente pintor de caracteres e a pintura de Zêuxis não apresenta caráter nenhum. (VI, 1450a)

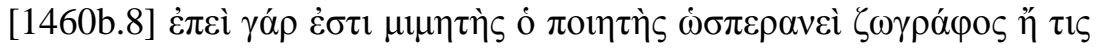

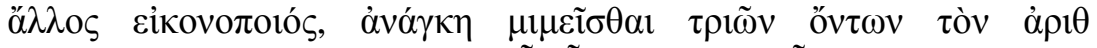

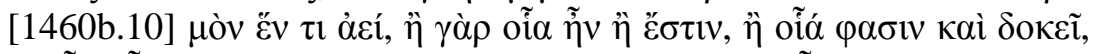

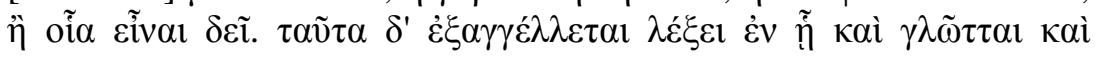

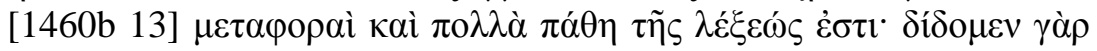

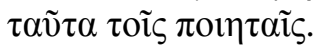

\footnotetext{
${ }^{9}$ Para todas as citações da Poética adotamos a tradução de Eudoro de Souza. São Paulo: Ars Poetica. 1992.

${ }^{10}$ Acerca da relação da relação homológica entre a pintura de Zêuxis e a Retórica, cf. Martins, P. "Cicero: The Picturing of a Rhetoric”. 2010. [Aguarda Referee da Classical Philology, University of Chicago.]
} 
O poeta é imitador, como o pintor ou qualquer outro imaginário; por isso, sua imitação incidirá num destes três objetos: coisas quais eram ou quais são, quais os outros dizem que são ou quais parecem, ou quais deveriam ser. Tais coisas, porém, ele as representa mediante uma elocução que compreende palavras estrangeiras e metáforas, e que, além disso, comporta múltiplas alterações, que efetivamente consentimos ao poeta. $(\mathbf{X X V}, \mathbf{1 4 6 0 b})$

No primeiro excerto, o componente que estabelece a relação entre pintura e poesia é o objeto de imitação, tanto o poeta como o pintor representam homens superiores, inferiores ou iguais a nós. A partir dessa proposição, considerando a classificação da poesia que temos na Poética, é possível estabelecer um quadro comparativo com os gêneros poéticos e pictóricos, conforme se observa no quadro elaborado por Paulo Martins ${ }^{11}$ :

\begin{tabular}{|c|c|c|c|c|c|}
\hline GÊNERO & PINTURA & POESIA & Imitação & INNDOLE & IMITADO \\
\hline $\begin{array}{c}\text { ELEVADO } \\
\text { GENUS NOBILE }\end{array}$ & 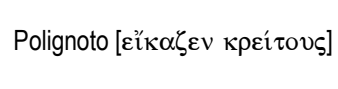 & Homero/Sófocles & Épica/Trágica & 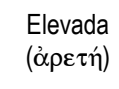 & $\begin{array}{l}\text { Superior } \\
\text { Virtude }\end{array}$ \\
\hline $\begin{array}{c}\text { MÉdIO } \\
\text { GENUS MEDIUM }\end{array}$ & 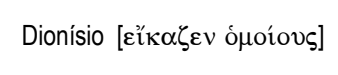 & Píndaro/Alceu & $\begin{array}{l}\text { Lírica Coral - Epiníicios } \\
\text { Lírica Monódica - Odes }\end{array}$ & Média & $\begin{array}{l}\text { Igual a nós } \\
\text { Mesotes }\end{array}$ \\
\hline $\begin{array}{c}\text { BAIXO } \\
\text { GENUS HUMILE }\end{array}$ & 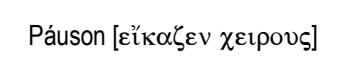 & Arquilloco/Semônides de Amorgos & lâmbica/Satirica & 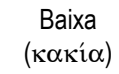 & $\begin{array}{l}\text { Inferior } \\
\text { Vicio }\end{array}$ \\
\hline
\end{tabular}

A segunda passagem trata da Tragédia, que pode ser feita sem caracteres e, para corroborar essa teoria, exemplifica com a pintura, pois prova que a pintura pode ou não ter caracteres - não se deve ignorar que o gênero poético comparado aqui com a pintura é destinado à apresentação teatral; portanto, o aspecto visual também é fundamental para a composição da poesia trágica, o que torna a relação proposta mais evidente. Por fim, afirma que o "poeta é imitador, como o pintor (...)" e, por essa razão, eles mantêm a mesma relação com o objeto de imitação, cuja representação pode ou não ser como o original.

\footnotetext{
11 "Polignoto, Páuson, Dionísio e Zêuxis - Uma leitura da pintura antiga clássica grega”. 2008. [Aguarda publicação na Revista Phaos. Campinas: IEL/UNICAMP]
} 
A pintura já aparecera na Política ${ }^{12}$ de Aristóteles durante a discussão acerca da inclusão da música na educação, que não é apenas uma forma de entretenimento, mas também a representação de certas emoções e de qualidades morais que, quando as músicas são ouvidas, nos levam a operar a correspondência destas imitações com a realidade:

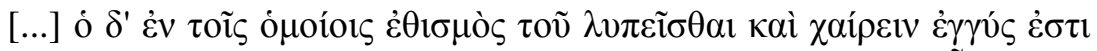

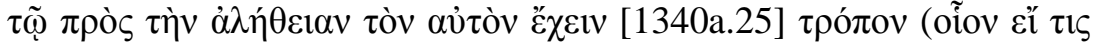

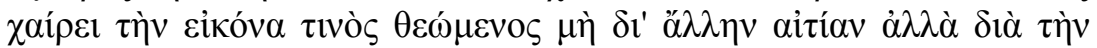

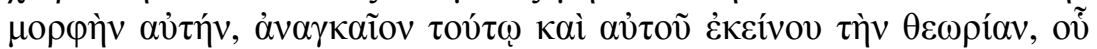

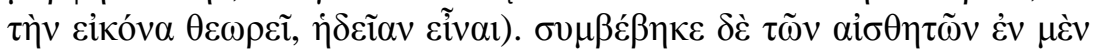

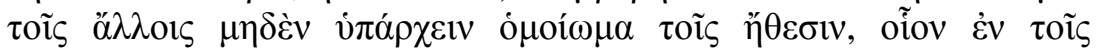

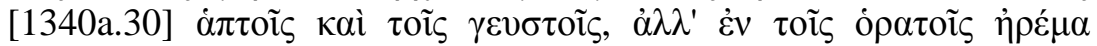

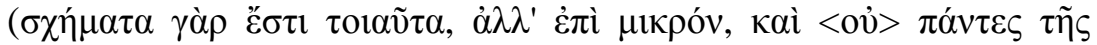

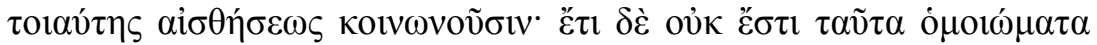

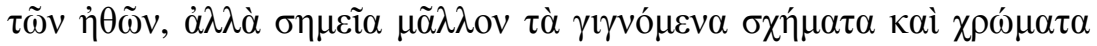

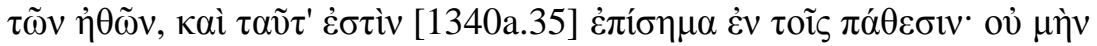

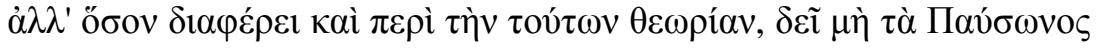

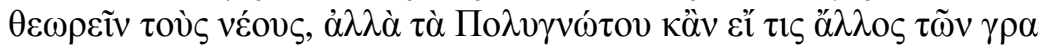

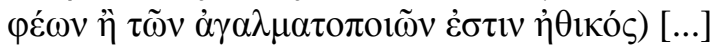

[...] a tendência para sofrer e deleitar-se com representações da realidade é extremamente relacionada com o sentimento diante dos próprios fatos (por exemplo, se um homem se deleita na contemplação da estátua de alguém por nada mais que sua beleza, a visão real da pessoa cuja estátua ele contemplou deve ser-lhe igualmente agradável); acontece que os objetos atuantes sobre outros sentidos não transmitem qualquer sensação semelhante às qualidades do caráter, como por exemplo os que afetam o tato e o paladar (embora os objetos que afetam a visão tenham uma ligeira ação desse tipo, pois há formas que representam um caráter, mas somente em pequena escala, e nem todos os homens são capazes de provar esta espécie de sensação); as obras de artes visuais não são representações de emoções do caráter, pois as formas e cores são meras indicações de tais emoções, e estas indicações são apenas sensações corpóreas simultâneas com as emoções; sua relação com a moral é diminuta, mas uma vez que há alguma os jovens devem ser instruídos para olhar não as obras de Páuson, mas as de Polígnotos, ou de qualquer outro pintor ou escultor que reproduza sentimentos de ordem moral. (1340a) [...]

Ao contrário da música, a pintura nem sempre reproduz as disposições morais e mesmo quando o faz é em pequena escala; ainda assim, a arte imagética é capaz de indicar certos traços de caráter, diferentemente do tato e do paladar, por meio das formas e das cores, por isso ele aconselha para a educação dos jovens obras como as de Polignoto, pois ele imitava tais disposições, e desaconselha as de Páuson, que não as

\footnotetext{
${ }^{12}$ Edição adotada: Tradução de Mário da Gama Kury. Brasília: Editora da Universidade de Brasília.
} 1985 . 
representava. Vale lembrar que Aristóteles já os mencionara na Poética, conforme já vimos Polignoto representa homens superiores, Páuson, inferiores. Portanto, Aristóteles aconselha a pintura de matéria elevada e com imitação das características morais para a educação.

Na Epistola ad Pisones de Horácio (I a.C.), considerada como sua Ars Poetica, ele também menciona a relação existente entre poesia e pintura ${ }^{13}$ :

\author{
Humano capiti ceruicem pictor equinam \\ iungere si uelit et uarias inducere plumas \\ undique conlatis membris, ut turpiter atrum \\ desinat in piscem mulier formosa superne, \\ spectatum admissi risum teneatis, amici? \\ Credit, Pisones, isti tabulae fore librum \\ permisilem, cuius, uelit aegri somnia, uanae \\ fingentur species, ut nec pes nec caput uni \\ reddatur formae. "Pictoribus atque poetis \\ quidlibet audendi semper fuit aequa potestas."

Se um pintor quisesse juntar a uma cabeça humana um pescoço de cavalo e a membros de animais de toda a ordem aplicar plumas variegadas, de forma a que terminasse em torpe e negro peixe a mulher de bela face, conteríeis vós o riso, ó meus amigos, se a ver tal espetáculo vos levassem? Pois crede-me, Pisões, em tudo a este quadro se assemelha o livro, cujas idéias vãs se concebessem quais sonhos de doente, de tal modo que nem pés nem cabeça pudessem constituir uma só forma. Direis vós que 'a pintores e a poetas igualmente se concedeu, desde sempre, a faculdade de tudo ousar'. (v.1-10)

Segnius irritant animos demissa per aurem 180 quam quae sunt oculis subiecta fidelibus et quae ipse sibi tradit spectator $[\ldots]$

[...] $\mathrm{O}$ que se transmitir pelo ouvido, comove mais debilmente os espíritos do que aquelas coisas que são oferecidas aos olhos, testemunhas fiéis, e as quais o espectador apreende por si próprio. [...] (v.180-82)

Vt pictura poesis; erit quae, si proprius stes, te capiat magis, et quaedam, si longius abstes; haec amat obscurum, uolet haec sub luce videri, iudicis argutum quae non formidat acumen; haec placuit semel, haec deciens repetita placebit.

\footnotetext{
${ }^{13}$ Edição adotada: Tradução de R. M. Rosado Fernandes. Lisboa: Inquérito. 1984.
} 
Como a pintura é a poesia: coisas há que de perto mais te agradam e outras, se a distância estiveres. Esta quer ser vista na obscuridade e aquela à viva luz, por não recear o olhar penetrante dos seus críticos; esta, só uma vez agradou, aquela, dez vezes vista, sempre agradará. (v.361-65)

Logo no começo ele trata da coerência com que o pintor deve constituir sua obra e, em seguida, compara a pintura ao livro e, o pintor, ao poeta. A proposição a respeito da unidade da obra está de acordo com a teoria aristotélica; a verossimilhança é tida como fundamental em sua poética e Horácio, para abordar tal questão, de tamanha relevância, aplica o símile mencionado acima, demonstrando assim mais uma faceta comum a ambos - não se trata mais do objeto de imitação, ambos partilham também as mesmas estratégias de composição.

No segundo excerto, discute-se acerca das coisas que podem ser encenadas: os fatos relatados têm menor impacto sobre o público do que aquilo que é "oferecido aos olhos" (quae sunt oculis subiecta), pois, dessa maneira, o espectador é testemunha dos fatos, consequentemente, comove-se mais. Ainda assim, o decoro exige que alguns fatos não apareçam, apenas devem ser relatados, é o caso das cenas de crimes nas tragédias.

Na última passagem mencionada, destaca-se a expressão "Vt pictura poesis", pois se trata de um símile que estabelece diretamente a analogia entre pintura e poesia, seguida de uma breve explicação que corrobora tal afirmação. Horácio levanta três aspectos próprios da pintura: a distância, a luz e a capacidade de deleitar - algumas devem ser observadas de perto, sob a luz e sempre agradarão; outras, à distância, na obscuridade e agradarão apenas uma vez. ${ }^{14}$

Entende-se que o mesmo ocorre na poesia: alguns gêneros, como o épico, devem ser observados à distância, pois se trata de um poema longo e, portanto, o poeta deve trabalhar para a unidade da obra. Não podemos esquecer que, nos versos anteriores a tal

\footnotetext{
${ }^{14}$ Recomendo o artigo: TRIMPI, W. "Horace's Ut pictura poesis: The argument for stylistic decorum". In: Traditio. Nova York: Fordham University Press. 1978, vol.34, pp. 29-73. Cf.pp. 30-1: O autor analisou a passagem e declarou haver certas dificuldades para sua interpretação, demonstrando a ruptura de paralelismo na comparação: a primeira relação entre pintura e poesia é a distância, chamada por ele de A1 e A2, que nas comparações subsequentes, em vez do que se espera, A1 equivale a B2 (sob a luz) e C2 (várias vezes agradará) e A2 equivale a B1 (na obscuridade) e C1 (só uma vez agradará). Os dois primeiros itens da comparação não são paralelos, formam um quiasma; no entanto, o terceiro item não segue esse procedimento e permanece numa relação paralela com o item anterior. Na opinião do autor, Horácio torna a passagem um tanto confusa para aconselhar a evitar a obscuridade e retornar ao paralelismo simples do procedimento retórico, aplicado em gêneros como o epistolar aqui utilizado; porém, outros gêneros necessitam dessa obscuridade, como seria o caso da Épica e mesmo da Oratória.
} 
comparação, Horácio admite que até Homero durma na produção de obra tão extensa, por essa razão, deve ser observada também na obscuridade, o "olhar atento" notaria as falhas. Ao passo que outros, como o iâmbico ou lírico, devem ser vistos de perto, sem desconsiderar nenhum detalhe, em razão de sua breve extensão, tudo deve contribuir para formar a unidade do poema, exigindo que seja visto de perto e sob a luz ${ }^{15}$.

$\mathrm{O}$ aspecto da distância lembra as proposições já levantadas por Platão no que concerne à visualização de uma obra, tal como vimos no Sofista e em Parmênides. Assim como a escultura e a pintura, a poesia depende dos mesmos critérios de produção, visto que cada gênero se adapte para criar o efeito necessário e esperado pelo seu espectador/ leitor.

Outro tratado poético do qual se podem depreender conceitos referentes aos mecanismos aqui estudados é o Do Sublime, de autoria e datação imprecisa, mas atribuído geralmente a Longino, no século I d.C. Em dado momento, o autor compara a oratória à pintura:

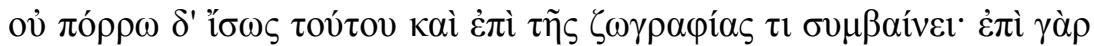

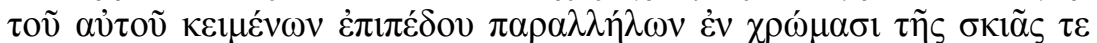

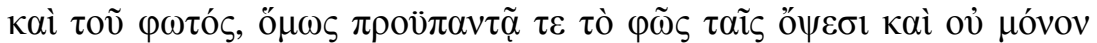

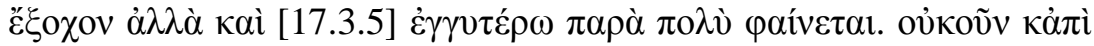

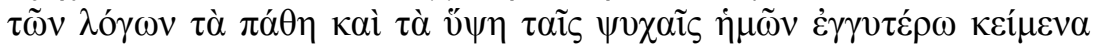

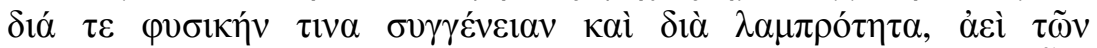

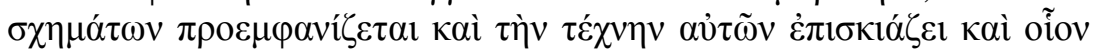
$\dot{\varepsilon} v \kappa \alpha \tau \alpha \kappa \alpha \lambda \hat{\psi} \psi \varepsilon 1 \tau \eta\rceil \varepsilon \tilde{i}$.

Disso talvez não difira muito o que acontece na pintura: embora postas em cores, lado a lado, no mesmo plano, a sombra e a luz, esta se oferece melhor à vista e aparenta estar não só em relevo, mas muito mais perto. Nos discursos, pois, o patético e o sublime, mas aproximados de nossa alma, graças a uma afinidade natural e ao brilho, sempre se mostram antes das figuras, obumbrando e mantendo encoberto o artifício destas ${ }^{16}$. (XVII, 3)

\footnotetext{
15 Essa proposição está bem explicada no artigo: MARTINHO, M. dos Santos. "O monstrum da Arte Poética de Horácio”. In: Letras Clássicas, 2000, n4, pp.191-265. Segue-se o excerto que resume a ideia dessa passagem horaciana: "Ora, o poema que quer ser visto sob a luz seria o breve, cuja elocução o poeta burila para que seja luzidia; o poema que ama o escuro seria o longo, cuja disposição o poeta planeia para que seja coerente. Pois, de um lado, o poema breve, porque é uma pequena tira, exige do poeta que lapide uma a uma as palavras, isto é, que labore na elocução, mas, porque carece de partes, dispensa-o da disposição. De outro lado, o poema longo, porque se compõe de partes, exige do poeta que encadeie tiras inteiras de palavras, isto é, que labore na disposição, mas, porque transcende a singularidade das palavras, permite-lhe que cochile na elocução. Assim, o poema breve é composição mais minuciosa, cujas palavras se devem inspecionar; o poema longo é composição mais difusa, cujo todo se deve contemplar." (pp.208). ${ }^{16}$ Para todas as citações Do Sublime adotamos a tradução de Jaime Bruna. São Paulo: Cultrix. 1997.
} 
Ao tratar do emprego das figuras em geral, subentendendo-se a associação com a pintura, afirma-se que conferem brilho ao discurso; no entanto, o uso excessivo pode comprometer-lhe a credibilidade. Assim, a figura não deve transparecer; para tal é preciso que o efeito produzido sobre o público seja intenso, desviando a atenção das estratégias utilizadas e aproximando o leitor do resultado, pois o que se aproxima da alma é capaz de encobrir o uso das figuras.

Advém daí a comparação, da mesma maneira que o discurso sublime e o patético encobrem o emprego das figuras na oratória, a luz disfarça a sombra na pintura, pois a primeira é mais evidente, mas graças ao efeito provocado pela outra. $\mathrm{O}$ emprego de luz e sombra já aparecera como técnica da pintura nos diálogos de Platão, onde a sombra contribui para compor a unidade da imagem vista à distância.

\section{I.1. AMPLIFICAÇÃO}

\section{Aristóteles}

No que concerne à amplificação, pode-se entender sua relação com a descrição e a evidência partindo da definição aristotélica que aparece na Retórica. Ele expõe claramente que a aúxesis (amplificação) é um recurso apropriado ao discurso do gênero epidítico, dessa forma é possível tornar mais belas ou mais feias as ações do indivíduo ${ }^{17}$ (tendo em vista naturalmente as duas chaves possíveis do demonstrativo):

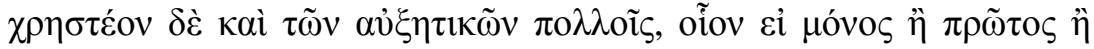

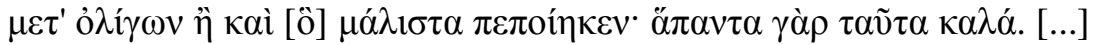

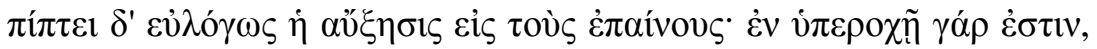

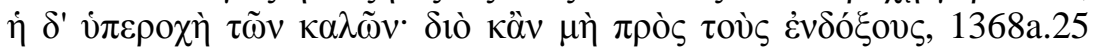

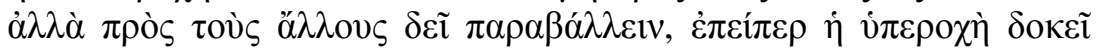

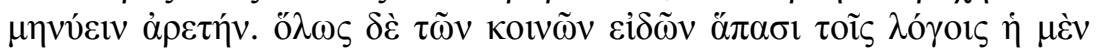

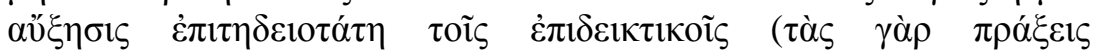

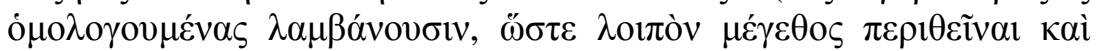

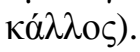

[1368a38] Devemos igualmente empregar muitos meios de amplificação; por exemplo, se um homem agiu só, ou em primeiro lugar, ou com poucas pessoas, ou se teve a parte mais relevante na acção; pois todas estas circunstâncias são belas. [...] A amplificação enquadra-se logicamente nas formas de elogio, pois consiste em superioridade e superioridade é uma das coisas belas. Pelo que, se não é possível comparar alguém com pessoas de renome, é pelo menos

\footnotetext{
${ }^{17}$ Cf. nota 1.
} 
necessário compará-lo com as outras pessoas, visto que a superioridade parece revelar a virtude. Entre as espécies comuns a todos os discursos, a amplificação é, em geral, a mais apropriada aos epidícticos; pois estes tomam em consideração as acções por todos aceites, de sorte que apenas resta revesti-las de grandeza e de beleza.

A amplificação é considerada parte importante do elogio porque tudo que se acrescenta de bom a respeito de um indivíduo o faz parecer melhor; devem-se, portanto, mencionar todas as circunstâncias que ajudem a destacar a grandeza do indivíduo, inclusive aquelas que são derivadas do tempo e das ocasiões, quantas vezes obteve sucesso em algo, se lhe foi inventada alguma honraria, se teve uma estátua erguida em sua homenagem; no entanto, caso não haja matéria suficiente para o elogio, a pessoa deve ser comparada com alguém de renome, pois parecer melhor que os virtuosos amplifica suas qualidades; ainda assim, se não for possível comparar com alguém de renome, é necessário comparar com outras pessoas, para demonstrar superioridade, pois por meio disso revela-se a virtude.

Como já dissemos, é um recurso típico do discurso epidítico, que não discute a veracidade do que se diz, mas serve para enaltecer o indivíduo sobre o qual se fala. No gênero deliberativo, os exemplos são mais apropriados, pois servem como base para julgarmos o futuro. Os entimemas, por sua vez, servem aos discursos judiciários, com o objetivo de explicar e demonstrar o que aconteceu.

Assim como o elogio, a invectiva também compõe o gênero epidítico e, consequentemente, a amplificação também é empregada nesses casos, mas com procedimentos contrários aos do elogio, já que a censura deriva dos contrários.

\section{Cícero}

Os tratados de oratória, tais como os de Cícero, comparam a "arte do bem dizer" à pintura ou à escultura com frequência. Com base nisso, entende-se a relação da amplificação com os recursos aqui estudados, uma vez que os resultados obtidos com esse procedimento conferem, muitas vezes, certa visibilidade ao discurso.

A enargia ou evidência aparece em algumas proposições ciceronianas, embora ele não empregue uma terminologia específica para o procedimento. Dentre suas obras, adotamos De Partitione Oratoria e De Oratore como base para a conceituação da amplificação, das quais efetuamos leitura mais detalhada. 
Cícero explica mais detidamente a amplificação no De Partitione Oratoria, nos $\S 27$ e $52-8^{18}$ :

27. [...] Quattuor esse eius partes, quarum prima et postrema ad motum animi ualet - is enim initiis est et perorationibus concitandus -, secunda, narratio, et tertia, confirmatio, fidem facit orationi. Sed amplificatio quamquam habet proprium locum, saepe etiam primum, postremum quidem fere semper, tamen reliquo in cursu orationis adhibenda est, maximeque cum aliquid aut confirmatum esta ut reprehensum. Itaque ad fidem quoque uel plurimum ualet; est enim amplificatio uehemens quaedam argumentatio, ut illa docendi causa sit, haec commouendi.

27. [...] Quatro são as suas partes [do discurso], das quais a primeira e a última são capazes de mover o ânimo - com efeito, ele deve ser movido nos inícios e nas perorações -, a segunda, a narração, e a terceira, a confirmação, confere credibilidade ao discurso. Mas a amplificação, ainda que tenha um lugar próprio - muitas vezes o primeiro, na verdade, quase sempre é o último, - deve ser, contudo, colocada no restante do discurso, sobretudo quando há algo para se confirmar ou repreender. Portanto, é também muitíssimo eficaz para a credibilidade; pois a amplificação é certa argumentação veemente, de modo que esta tenha como objetivo ensinar, aquela, comover.

52. Facilior est explicatio perorationis. Nam est diuisa in duas partes, amplificationem et enumerationem. Augendi autem et hic est proprius locus in perorando, et in cursu ipso orationis declinationes ad amplificandum dantur confirmata re aliqua aut reprehensa. 53. Est igitur amplificatio grauior quaedam affirmatio quae motu animum conciliet in dicendo fidem. Ea et uerborum genere conficitur et rerum. Verba ponenda sunt quae uim habeant illustrandi nec ab usu sint abhorrentia, grauia, plena, sonantia, iuncta, facta, cognominata, non uulgata, superlata, in primisque translata; nec in singulis uerbis sed in continentibus soluta, quae dicuntur sine coniunctione, ut plura uideantur. 54. Augent etiam relata uerba, iterata, duplicata, et ea quae ascendunt gradatim ab humilioribus ad superiora; omninoque semper quasi naturalis et non explanata oratio, sed grauibus referta uerbis, ad augendum accomodatior. Haec igitur in uerbis, quibus actio uocis, uultus et gestus congruens et apta ad animos permouendos accomodanda est. Sed et in uerbis et in actione causa erit tenenda et pro re agenda; nam haec quia uidentur perabsurda cum grauiora sunt quam causa fert, diligenter quid quemque deceat iudicandum est. [XVI] 55. Rerum amplificatio sumitur eisdem ex locis omnibus quibus illa quae dicta sunt ad fidem; maximeque definitiones ualent conglobatae et consequentium frequentatio et contrariarum et dissimilium et inter se pugnantium rerum conflictio, et causae, et ea quae sunt de causis orta, maximeque similitudines et exempla; fictiae etiam personae, muta denique loquantur; omninoque ea sunt adhibenda, si causa patitur, quae magna habentur, quorum est duplex

${ }^{18}$ Tradução nossa. 
genus: 56. alia enim magna natura uidentur, alia usu - natura, ut caelestia, ut diuina, ut ea quorum obscurae causae, ut in terris mundoque admirabilia quae sunt, ex quibus similibusque, si attendas, ad augendum permulta suppetunt; usu, quae uidentur hominibus aut prodesse aut obesse uehementius, quorum sunt genera ad amplificandum tria. Nam aut caritate mouentur homines, ut deorum, ut patriae, ut parentum, aut amore, ut fratrum, ut coniugum, ut liberorum, ut familiarium, aut honestate, ut uirtutum, maximeque earum quae ad communionem hominum et liberalitatem ualent. Ex eis et cohortationes sumuntur ad ea retinenda, et in eos a quibus ea uiolata sunt odia incitantur et miseratio nascitur. 57. [Proprius locus est augendi in his rebus aut amissis aut amittendi periculo.] Nihil est enim tam miserabile quam ex beato miser, et hoc totum quidem moveat, si bona ex fortuna quis cadat, et a quorum caritate diuellatur, quae amittat aut amiserit, in quibus malis sit futurusue sit exprimatur breuiter - cito enim arescit lacrima, praesertim in alienis malis; nec quidquam in amplificatione nimis enucleandum est, minuta est enim omnis diligentia; hic autem locus grandia requirit. 58. Illud iam est iudicii, quo quaque in causa genere utamur augendi. In illis enim causis quae ad delectationem exornantur ei loci tractandi sunt qui mouere possunt exspectationem, uoluptatem; in cohortationibus autem bonorum ac malorum enumerationes et exempla ualent plurimum. In iudiciis accusatori fere quae ad iracundiam, reo plerumque quae ad misericordiam pertinent; nonnumquam tamen accusator misericordiam mouere debet et defensor iracundiam.

52. [...] Explicar a peroração é mais fácil. Pois foi dividida em duas partes, a amplificação e a enumeração. No entanto, não é só este o lugar próprio para aumentar, ao perorar: também no próprio discurso, são apresentados desvios para amplificar, quando algo é confirmado ou repreendido. 53. Pois a amplificação é certa afirmação mais grave que é capaz de conciliar a credibilidade no discurso com o movimento dos ânimos. Ela é produzida mediante o gênero de palavras e de assuntos. Devem ser colocadas as palavras que tenham força de ilustrar e que não estejam apartadas do uso: as palavras graves, as fortes, as sonoras, as compostas, as criadas, as sinônimas, as batidas, as hiperbólicas, e, primeiramente, as metafóricas; não apenas em palavras sozinhas, mas naquilo que as contém, que são ditas sem conjunção para que pareçam mais numerosas. 54. Também aumentam as palavras repetidas, reiteradas, duplicadas e aquelas que se elevam gradativamente das coisas mais humildes para as superiores; sempre é mais apropriado para aumentar o discurso como se fosse natural e não esclarecido, mas cheio de palavras graves. Pois tais coisas estão nas palavras, com as quais deve ser empregada a ação congruente e apropriada da voz, do semblante e do gesto para comover os ânimos. Mas a causa deverá estar contida nas palavras e na ação e deverá ser feita em favor do assunto; com efeito, porque tais coisas parecem muito absurdas quando são mais graves do que a causa admite, que se deve julgar o que convenha a cada um cuidadosamente. (XVI) 55. A amplificação dos assuntos é tomada dos mesmos lugares em que se arrolaram as matérias pertinentes para a credibilidade; sobretudo, são eficazes as definições aglomeradas, a acumulação de consequências e o conflito de coisas contrárias, dissímeis e opostas entre si, e as causas, e as coisas que nasceram das causas, sobretudo as semelhanças 
e os exemplos; também falam as personagens fictícias, por fim, as coisas mudas; se a causa permite, devem-se apresentar inteiramente os assuntos, considerados grandes, dos quais o gênero é duplo. 56. Com efeito, uns assuntos parecem grandes por natureza, outros pelo uso. Por natureza, são assuntos celestes, divinos, aqueles de causas obscuras, as coisas que são admiráveis na terra e no mundo, é delas e a das semelhantes a ela, se prestares atenção, uma grande quantidade à disposição para aumentar; pelo uso são aqueles assuntos que parecem mais veemente serem úteis ou nocivos aos homens, dos quais os gêneros para amplificar são três. Pois os homens ou são movidos pela caridade, como dos deuses, da pátria, dos parentes, ou pelo amor, como dos irmãos, dos cônjuges, dos filhos, dos familiares, ou pela honestidade, como da virtude e, sobretudo, daquelas que contribuem para a comunhão e bondade dos homens. De tais coisas, tomam-se as exortações para aquilo que deve ser preservado e, para aqueles que as violaram, são incitados os ódios e nasce a comiseração. 57. [Há um lugar próprio para o que se deve aumentar em tais coisas perdidas ou em perigo de se perder.] Com efeito, nada há de tão triste quanto passar de ditoso a miserável e, certamente, que isso tudo comova, se alguém cair da boa fortuna e for afastado da caridade de alguns, o que perder e tiver perdido, em quais males esteja ou estará, que seja exposto brevemente - com efeito, rapidamente a lágrima seca, principalmente em males alheios; e nada deve ser esclarecido demasiadamente na amplificação, pois toda a diligência é pequena; este, porém, é o lugar de coisas grandes. 58. Agora, aquilo que é do julgamento, qual gênero de amplificação façamos uso em cada causa. Com efeito, naquelas causas que são ordenadas para deleitar, devem ser empregados os lugares que podem mover a expectativa, a admiração e o prazer; porém, nas exortações, as enumerações dos bens e dos males e os exemplos são muito eficientes. Nos julgamentos, geralmente, pertencem ao acusador as coisas para a iracúndia, ao réu, quase sempre, as coisas para a misericórdia; contudo, algumas vezes, o acusador deve mover a misericórdia e o defensor, a iracúndia.

A amplificação é uma das partes da peroração, juntamente com a enumeração, embora ela possa ser utilizada ao longo de todo o discurso, ocorre que a peroração é uma parte apropriada para comover, assim como o início - é o que Cícero afirma no \$27, quando já nos adianta a função da amplificação, afirmando que ela pode aparecer em todo momento ao se confirmar ou censurar algo no discurso, com o objetivo não apenas de comover como também de reforçar a credibilidade daquilo que se diz afirmação reforçada no $\$ 53$.

Prosseguindo com a descrição da amplificação, ainda na mesma obra, ela se faz de palavras (genere uerborum) e assuntos ou temas (genere rerum): quanto às palavras, devem ter força para ilustrar - termo que nos remete ao campo semântico da evidência (Verba ponenda sunt quae uim habeant illustrandi [...]) - além de outras características, tais como: em primeiro lugar, devem ser metaforizadas ([...] in primisque translata), 
podem ser repetidas, confirmadas ou acrescentadas, também pode ascender gradativamente das coisas humildes para as superiores, as palavras devem, ainda, ser empregadas em conjunto, para que tais procedimentos se destaquem mais.

Em relação aos assuntos, os mesmos loci atribuídos para tornar o discurso crível (§34-40) podem ser empregados aqui, em resumo: elementos extraídos de partes da narração que provam a verossimilhança, tais como as pessoas, os lugares, o tempo, os feitos, as ocorrências e a natureza do assunto e das ocupações (estes lembram as circunstâncias mencionadas antes por Aristóteles para demonstrar a grandeza do indivíduo) - tais elementos devem ser escolhidos para se fazer uma conjectura; outros argumentos são vestígios que podem ser percebidos pelos sentidos, ou qualquer indício de premeditação que possa ser mostrado; o uso do exemplo com base em algo verdadeiro introduz um paralelo e auxilia na comoção, estabelecendo maior credibilidade.

Cícero nos apresenta os recursos para amplificação dos assuntos resumidamente no §55, destacando o uso das semelhanças e dos exemplos, se necessário, personagens fictícios, ou mesmo as coisas mudas, devem falar. Os assuntos grandiosos são preferíveis, os quais podem ser classificados segundo a natureza ou o uso: o primeiro relaciona-se aos assuntos divinos, instrumentos fáceis para operar a amplificação, o outro, trata de assuntos que podem ser úteis ou prejudiciais aos homens, no caso da amplificação podem ser a caridade, o amor e a honestidade, pois estes afetam o público. A mudança de fortuna é outro locus da amplificação, pois isso é digno de compaixão, entretanto, não se deve prolongar demais, pois nada deve ser explicado em detalhes na amplificação uma vez que esse é o lugar de temas grandes.

A amplificação deve se adaptar a cada causa: se o objetivo é delectare (aqui se enquadra o gênero epidítico ou demonstrativo) é preciso utilizar loci "que podem mover a expectativa, a admiração, o prazer", ao passo que, no discurso deliberativo, são mais úteis a enumeração dos bens e dos males e os exemplos, e, no judiciário, o orador deve mover a misericórdia ou a ira, dependendo de sua posição. Portanto, a amplificação é um recurso admitido nos três gêneros retóricos.

A partir dessa caracterização, entendemos que a amplificação é um procedimento que envolve o uso de inúmeras figuras, de vários tipos; a evidência constitui-se como uma delas, que é tida como figura de pensamento, conforme classificação usual - Cícero trata a respeito de figura de pensamento quando cita os dois tipos de figura no De Oratore, III, 200: o orador precisa conhecer as figuras, tanto de 
palavras (uerborum) como de pensamentos (sententiarum) para ornar o discurso. O que diferencia basicamente esses dois tipos é que a figura de palavra depende da maneira como são empregadas as palavras, se sofrem alteração então a figura se perde, ao passo que a de pensamento permanece, ainda que haja alteração, pois pertence a um âmbito maior.

O conceito de amplificação aparece no De Partitione Oratoria com uma extensa explicação, talvez em razão do caráter mais sistemático da obra, ao passo que, no $D e$ Oratore, menciona-se diversas vezes o procedimento, mas sempre relacionado a alguma questão sobre a arte oratória em discussão no diálogo. Portanto, dessa segunda obra de Cícero, nos importa buscar as comparações que faz acerca da arte verbal e a não-verbal, além das afirmações a respeito da importância da visão, pois tais questões também são indispensáveis para a compreensão da enargia/ evidência. Antes, porém, ressaltamos que as proposições do diálogo partem de personagens diversas; portanto, algumas das questões são produtos dessa discussão e não há uma conclusão, uma vez que tudo é defendido com maestria pelas personagens. Assim, seria equivocado dizer que Cícero assume a posição de uma das personagens, ainda que alguns teóricos façam isso.

Em primeiro lugar, devemos expor as passagens a respeito da amplificação no De Oratore para exemplificar. Em I, §143, Cícero afirma que, ao fim do discurso, o orador deve amplificar e aumentar (amplificanda et augenda) o que é favorável para sua causa e debilitar o que favorece a parte contrária (infirmanda atque frangenda). Em I, $\$ 221$, o orador amplifica e orna (amplificat atque ornat) com seu discurso as coisas que parecem desejáveis na vida. No livro II, §80, após enumerar brevemente as partes do discurso, diz que, antes de perorar, uma digressão pode ser inserida para ornar e amplificar (ornandi aut augendi). Nota-se que, em dois dos fragmentos destacados, a amplificação aparece em par com o ornato, tema que será tratado ao longo do terceiro livro da mesma obra. Em resumo, entende-se o ornato como o conjunto de virtudes do discurso capazes de torná-lo mais eficiente em seu objetivo.

Tal aspecto deve ficar mais claro no livro III, conforme veremos a seguir. No $\S 104-5$, a amplificação aparece como um procedimento que ornamenta (amplificare rem ornando), por meio do qual o tema pode ser elevado ou rebaixado e é muito eficiente para persuadir o público, tanto quando se explica algo (docere) como para mover os ânimos (mouere) e nada é mais apropriado no gênero epidítico do que o recurso da amplificação ([...] laudandi et uituperandi; nihil est enim ad exaggerandam et 
amplificandam orationem accommodatius quam utrumque horum cumulatissime facere posse.), pois aumentamos as virtudes ou os vícios do indivíduo.

No contexto das figuras de pensamento, no §202, algumas são capazes de ilustrar e amplificar a causa exposta (ad inlustrandum [...] ad amplificandum) novamente, temos a relação entre a amplificação e a evidência:

Nam et commoratio una in re permultum mouet et illustris explanatio rerumque quasi gerantur sub aspectum paene subiectio, quae et in exponenda re plurimum ualent et ad illustrandum id quod exponitur et ad amplificandum, ut eis qui audient illud quod augebimus quantum efficere oratio poterit tantum esse uideatur [...].

Pois muito comove demorar numa matéria, explicar claramente os assuntos e colocar diante dos olhos os assuntos que contam para sua exposição, tanto para ilustrar o que se expõe, como para amplificá-la, de maneira que quem que ouve aquilo que amplificamos julgue que exista nas proporções que o discurso for capaz de produzir [...]. ${ }^{19}$

Já percebemos que a relação da evidência com a amplificação reside no resultado que se pretende obter - a amplificação realça o que é dito, logo, a evidência é um método amplificativo com uma finalidade específica: não apenas enaltecer o conteúdo do discurso como torná-lo visível.

\section{Quintiliano}

Ao tratar do método pelo qual se pode elevar ou diminuir o tema, Quintiliano discorre acerca da amplificação, no livro VIII da Institutio Oratoria, capítulo 4 procedimento que se concentra nas palavras que descrevem o objeto, por exemplo, se um homem foi espancado, dizemos que foi assassinado, ou se falarmos de um homem desonesto, dizemos que é um ladrão. Este tipo de amplificação torna-se mais evidente por meio do uso de palavras de significado mais forte em comparação às palavras que são substituídas.

Quintiliano considera quatro tipos de amplificação: acréscimo (incrementum), comparação (comparatio), silogismo (ratiocinatio) e acumulação (congeries).

O acréscimo é muito potente, faz parecer grande mesmo as coisas inferiores. Emprega-se por meio da elevação gradativa, ultrapassando às vezes os limites que o assunto comporta. Um exemplo fornecido por Quintiliano, §6 do capítulo 4, é a

\footnotetext{
${ }^{19}$ Tradução nossa.
} 
descrição de Lauso na Eneida, cuja característica se destaca com o uso de um superlativo:

\author{
quo pulchrior alter \\ Non fuit, excepto Laurentis corpore Turni. \\ pois não houve outro mais belo do que ele, com \\ exceção de Turno Laurentino ${ }^{20}$. \\ (Eneida, 7, 649)
}

O acréscimo baseia-se na superioridade, a forma que se faz por comparação procura elevar a partir de coisas menores. Aumentando o que é inferior, necessariamente se exalta o que está acima. Segue o exemplo:

13. [...] An uero uir amplissimus P. Scipio, pontifex maximus, Ti. Gracchum mediocriter labefactantem statum rei publicae priuatus interfecit: Catilinam orbem terrae caede atque incendio uastare cupientem nos consules perferemus?

[...] Pois, na verdade, o homem mais ilustre P. Cipião, pontífice máximo, estando privado da vida pública, matou T. Graco que abalou mediocremente o estado: nós, cônsules, suportaremos Catilina desejoso de destruir a terra intera com a matança e com o incêndio? ${ }^{21}$

(Catlinárias, I, i, 3)

Segundo Quintiliano, Catilina é comparado a Graco, a constituição do estado está associada ao mundo todo, também se estabelece a associação entre um cidadão comum e os cônsules - todas as comparações podem ser expandidas. A comparação nessa passagem funciona como mecanismo argumentativo, pois se um cidadão comum, mas ilustre, foi capaz de assassinar aquele que ameaçava o estado, por que o consulado - maior que um único homem - deve suportar a traição de Catilina?

O silogismo produz seu efeito não na parte em que for introduzido, mas em outro ponto; algo é engrandecido para que haja acréscimo em outro lugar. Por meio do raciocínio os ouvintes são levados do primeiro ponto para o segundo que se quer enfatizar. Quando Cícero está prestes a reprovar Antônio por sua embriaguez e vômito, ele diz:

\footnotetext{
${ }^{20}$ Tradução nossa.

${ }^{21}$ Tradução nossa.
} 
16. [...] Tu, istis faucibus, istis lateribus, ista gladiatoria totius corporis firmitate.

[...] Tu, com essa garganta, esses flancos, essa força de gladiador no corpo inteiro ${ }^{22}$.

(Philippica. II, 25, 63).

Quintiliano questiona: Qual é a relação da garganta e dos flancos com sua embriaguez? A referência não seria supérflua, pois a par dessas características, somos capazes de estimar a quantidade de vinho que ele bebeu no casamento de Hípias e que não foi capaz de digerir apesar de sua força física. Logo, se uma coisa é inferida de outra, o termo ratiocinatio não é impróprio.

Por fim, a acumulação de palavras e sentenças (pensamentos) idênticas no significado é também considerada um tipo de amplificação. Nesse caso, a ascensão não é operada gradualmente, mas pela acumulação do acervo. Vejamos o exemplo:

27. Quid enim tuus ille, Tubero, destrictus in acie Pharsalica gladius agebat? cuius latus ille mucro petebat? qui sensus erat armorum tuorum? quae tua mens, oculi, manus, ardir animi? quid cupiebas? quid optabas?

Com efeito, Tuberão, o que fazia aquele teu gládio, tocado no combate da Farsália? O flanco de alguém sua ponta pedia? Qual foi a razão de tuas armas? Tua mente, olhos, mãos, o ardor do espírito, onde estavam? O que desejavas? O que pedias? ? $^{23}$

(Pro Ligario, III, 9)

Esta é a figura synathroismos para os gregos que consiste na acumulação de diferentes coisas, nesse exemplo, contudo, se observam a acumulação de detalhes que têm apenas um referente. O efeito é obtido fazendo as palavras se elevarem cada vez mais.

No fim do capítulo, §28, Quintiliano afirma que há ainda uma forma de diminuir (minuendi), oposta à amplificação, mas regulada por quase o mesmo método, uma vez que há tantos graus para se elevar como para se diminuir.

\footnotetext{
${ }^{22}$ Tradução nossa.

${ }^{23}$ Tradução nossa.
} 
A hipérbole é um tropo considerado por alguns como uma espécie de amplificação, pois aumenta a magnitude das coisas.

\section{Anônimo - Do Sublime}

$\mathrm{O}$ conceito da amplificação também é mencionado nesse tratado, destacamos a seguir as passagens que abordam o tema ${ }^{24}$ :

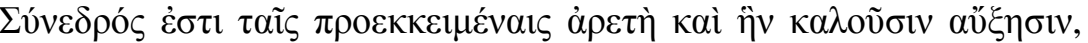

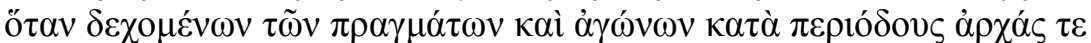

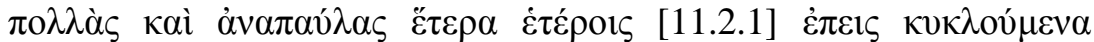

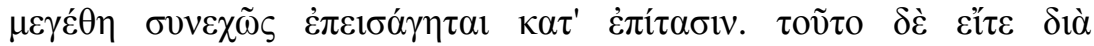

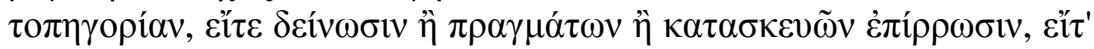

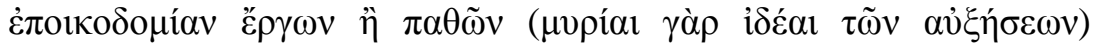

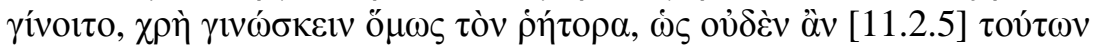

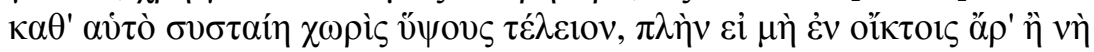

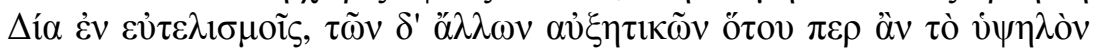

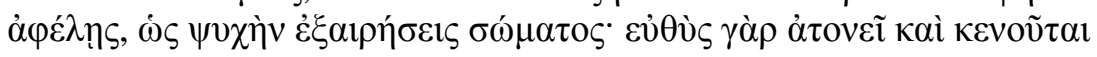

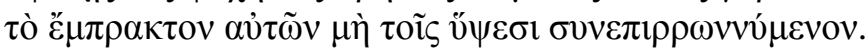

1. Associa-se às qualidades acima expostas a chamada amplificação, quando, admitindo o assunto e os debates, em seus períodos, muitos inícios e interrupções, o estilo se eleva gradativamente em frases que se acumulam cerradamente umas sobre as outras. 2. Quer isso resulte do desenvolvimento de lugares comuns, quer do encarecimento da realidade, ou dos artifícios, quer ainda do sábio arranjo dos fatos, ou das emoções (pois a amplificação tem milhares de formas), deve o orador, não obstante, saber que, de per si, sem o sublime, nenhum desses meios se manteria eficaz, salvo, por Zeus! para suscitar pena ou para atenuar o vigor; suprimir nas demais formas de amplificação o sublime é como arrancar a alma do corpo; logo se lhe enfraquece e esvazia a eficácia, quando não avigorada pelo condão do sublime. (XI, 1-2)

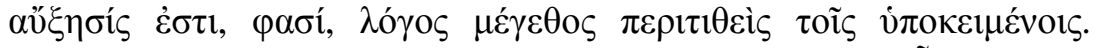

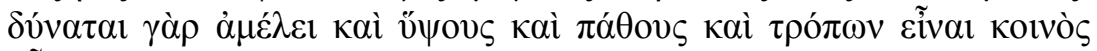

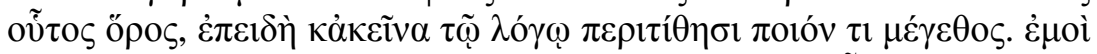

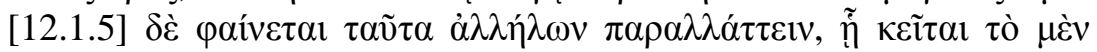

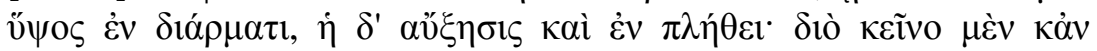

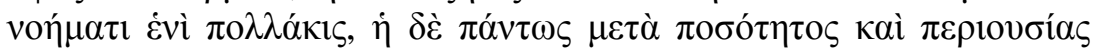

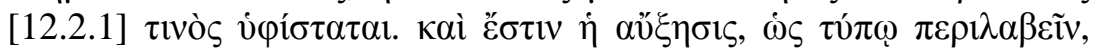

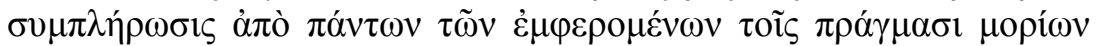

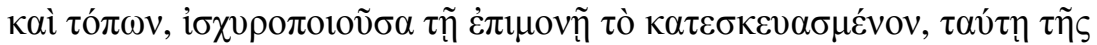

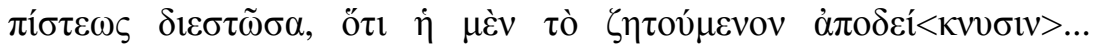

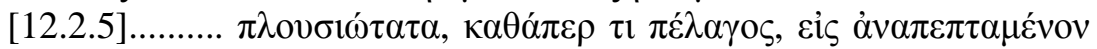

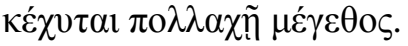

\footnotetext{
${ }^{24}$ Cf. nota 16.
} 
1. [...] Amplificação, dizem eles [os tratadistas], é uma linguagem que confere grandiosidade ao assunto. Essa definição pode caber indiferentemente ao sublime, à emoção e às figuras, visto como também esses recursos conferem ao discurso certa grandiosidade. A meu ver, a distinção entre eles está em consistir o sublime numa elevação; a amplificação, numa abundância; por isso, o primeiro se acha muitas vezes até num único pensamento, enquanto a segunda se acompanha sempre de quantidade e certa redundância. 2. A amplificação, em síntese, é uma aglomeração de todas as partes e tópicos ligados ao assunto, a qual, pela demorada insistência, reforça um arrazoado; ela difere da prova em que esta demonstra o ponto em debate [...]. (XII, 1-2)

A amplificação pode ser adotada para elevar, gradativamente, o discurso, por meio de recursos diversos, mas é inútil se o estilo não for sublime. O sublime difere da amplificação porque consiste na própria elevação, ao passo que, a amplificação, na abundância; por essa razão, seu mecanismo se baseia na "quantidade" de procedimentos empregados. O método da amplificação é entendido como um meio de reforçar a argumentação.

Nesse tratado a amplificação é colocada um degrau abaixo do sublime - tema central da obra - sua definição, porém, é compatível as já observadas em outros teóricos, pois de fato constitui uma série de aspectos relacionados ao assunto. No entanto, considerando a teoria dos demais, a amplificação também consiste na elevação, nem sempre é apenas um prolongamento do assunto, mas contribui para o enaltecimento de algo menor.

A partir do tratamento teórico dispensado à amplificação, vimos que são diversos os dispositivos que contribuem para seu resultado; a pormenorização de elementos constitutivos ou mesmo as comparações são aspectos que nos permitem associar a função da écfrase aos processos amplificadores.

\section{I.2. METÁFORA}

\section{Aristóteles}

A metáfora é um recurso retórico-poético bastante utilizado e o resultado obtido com o emprego desse tropo tem certo caráter imagético, uma vez que a relação estabelecida por ela implica o conhecimento prévio do objeto ou assunto tratado e permite imaginar um quadro com os elementos metaforizados. 
Antes de aprofundar a questão em torno da metáfora na Retórica, tratado no qual Aristóteles trata disso reiteradamente, é importante considerar a definição e classificação proposta por ele na Poética. O próprio autor menciona no seu tratado retórico ter exposto antes a classificação da metáfora e, portanto, não tratará de tal aspecto.

A metáfora, inserida na discussão acerca dos tipos de nomes, é o procedimento que transporta o nome de uma coisa para outra, com a seguinte classificação: "ou do gênero para a espécie, ou da espécie para o gênero, ou da espécie de uma para a espécie de outra, ou por analogia" ${ }^{25}$ (XXI, 1457b). Na analogia, tipo que ganha destaque na Retórica, conforme se verá mais adiante, a relação é estabelecida, geralmente, entre quatro termos, onde o segundo está para o primeiro na mesma relação em que o quarto está para o terceiro, neste caso, a metáfora ocorre quando um dos termos de um par é igualado ao termo do outro que mantém a analogia, como exemplo Aristóteles menciona: a urna está para Dionísio, assim como o escudo está para Ares, logo, a urna é o escudo de Dionísio.

Vejamos o tratamento acerca da metáfora na Retórica de Aristóteles. O discurso retórico fundamenta-se no efeito que provoca sobre o público, com a intenção, sobretudo, de argumentar em favor de algo, de maneira que se possa convencer o ouvinte. Há nesse tratado um capítulo do terceiro livro dedicado à discussão da metáfora; contudo, algumas das considerações feitas foram mencionadas em capítulos anteriores do mesmo livro. No capítulo 2, dedicado à clareza, está exposto que o discurso precisa ser claro; por essa razão, quando se quer torná-lo menos familiar para provocar admiração e, consequentemente, agradar, não se deve utilizar todo tipo de ornamento. Para que o discurso seja, ao mesmo tempo, claro e um tanto afastado, empregam-se apenas o termo "próprio" e a metáfora, pois esta última é amplamente utilizada e resulta em um discurso não-familiar, porém, claro. Ainda que haja certo afastamento, é possível dissimulá-lo, desse modo, o discurso será compreensível e agradável - essa é a maior virtude do discurso retórico, segundo Aristóteles.

A metáfora não deve se originar de coisas muito afastadas, mas de coisas semelhantes que pertençam ao mesmo gênero ou espécie, para designar algo que não tenha termo próprio, de maneira que a relação entre ambos seja evidente - é o que ocorre no enigma. A partir de bons enigmas, constituem-se metáforas apropriadas. A

\footnotetext{
${ }^{25}$ Cf. nota 9.
} 
metáfora deve ser extraída de coisas belas "quer em som, quer em efeito, quer em poder de visualização, quer numa outra forma de percepção" ${ }^{26}$ (1405b), pois assim será mais eficiente na sua tarefa, já que algumas palavras são mais apropriadas do que outras.

No capítulo 4, ao tratar do símile (eikón), inevitavelmente, fala também da metáfora ao expor a distinção de ambos por meio do seguinte exemplo: "lançou-se como um leão" - símile, "ele lançou-se um leão" - metáfora, portanto, o símile introduz uma expressão comparativa, ao passo que a metáfora estabelece a relação de igualdade diretamente. O símile pode ser utilizado na prosa, porém, não excessivamente, pois é um recurso poético.

A analogia já aparece aqui como a metáfora, que sempre mantém correspondência entre dois termos do mesmo gênero. No capítulo 11, Aristóteles afirma que os símiles de maior aceitação são, até certo ponto, metáforas. Quando expressos partindo de dois termos, assemelham-se à metáfora da analogia; é o caso de "o escudo, dizíamos, é o cálice de Ares", no qual se subentende a analogia. No capítulo 6, a analogia se mostra eficiente instrumento de amplificação, produzindo relações a partir de propriedades ausentes, tal como: "a trombeta é uma melodia sem acompanhamento de lira" (1408a).

No livro III da Retórica, capítulo 10, Aristóteles trata exclusivamente a respeito da metáfora. Aqui ele quer mostrar as expressões elegantes e de maior aceitação. Apesar de ser preciso talento natural e exercitação para produzi-las, ele afirma que também é possível por meio de um método.

As palavras têm um significado, as mais agradáveis são aquelas que proporcionam conhecimento, pois a aprendizagem fácil é agradável. Algumas palavras não são empregadas no seu sentido próprio: é o caso da metáfora; ainda assim, pode produzir conhecimento. O exemplo que ele nos fornece é extraído da Odisséia, XIV, 214, no qual a velhice é comparada à palha. Entendemos que o ensinamento se produz pelo conceito de que ambas já passaram por muitas coisas, ou seja, a experiência é adquirida somente com o passar do tempo: "Creio que só pelo exame da palha ainda podes um juízo/ do que era a espiga a fazer, pois sofri infortúnios sem conta."27. O mesmo ocorre com o símile que, por sua vez, é um tipo mais extenso de metáfora, pois tem um elemento a mais e não efetua a comparação diretamente; por isso, é menos agradável.

\footnotetext{
${ }^{26}$ Cf. Nota 1.

${ }^{27}$ Tradução de C.A. Nunes. Brasília: EDUNB. 1981.
} 
As expressões elegantes são comparadas aos entimemas por Aristóteles, pois ambos proporcionam uma aprendizagem rápida. Os entimemas adequados não devem ser superficiais e tampouco incompreensíveis; devem, na verdade, fazer surgir o conhecimento quando for pronunciado ou um pouco depois.

Alguns recursos no âmbito da expressão devem ser empregados, são eles: a antítese, a metáfora e a representação de uma ação ${ }^{28}$ de modo que essa apareça "diante dos olhos".

Dentre os tipos de metáfora, a mais reputada é a analogia; caso não haja relação ela será imprópria, pois os contrários tornam-se mais evidentes quando são colocados uns ao lado dos outros, conforme ele já mencionara no capítulo 2, 1405a. A metáfora da analogia pode também "trazer diante dos olhos", tal como o exemplo dado: "o caminho das minhas palavras passa pois pelo meio dos atos de Cares", onde, segundo Aristóteles, a expressão "pelo meio" produz a visualização. Mas esse aspecto não se restringe à analogia; a metáfora, em geral, tem a capacidade de produzir uma imagem, pois é preciso estabelecer uma relação imagética em alguns casos para compreender o sentido da metáfora. Destaco a seguir uma passagem da Retórica que expõe bem essa questão:

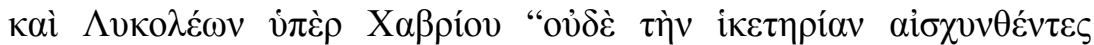

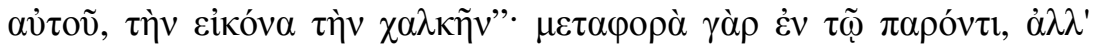

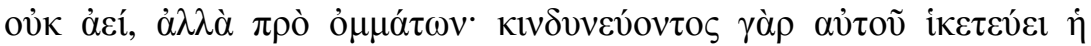

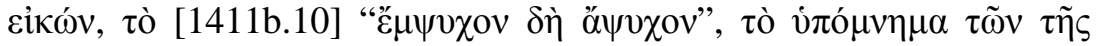

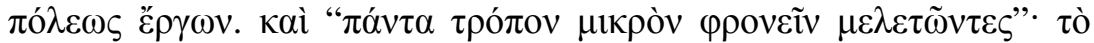

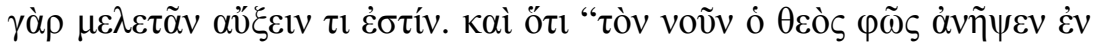

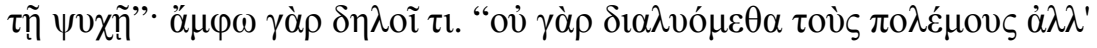

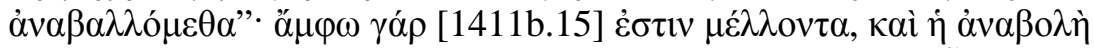

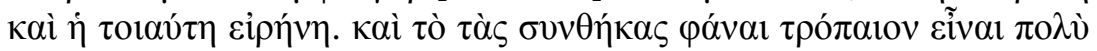

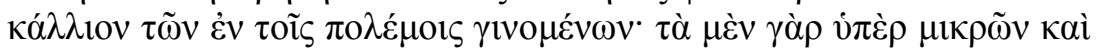

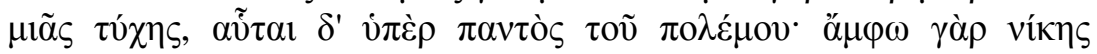
$\sigma \eta \mu \varepsilon \tilde{\alpha}$.

[...] Dizia Licoleonte em defesa de Cábrias: 'não tendo respeito pela atitude de súplica dele, pela estátua de bronze': é, pois, uma metáfora apropriada ao momento presente, não para sempre, mas para que produza uma visualização do objeto; pois estando ele em perigo, a estátua implora, e o inanimado torna-se animado: ou seja, a recordação dos seus feitos em prol da cidade. E 'por todos os meios, esforçam-se por pensar humildemente', pois 'esforçar-se' implica uma certa amplificação. E que 'deus acendeu a razão, luz no espírito':

\footnotetext{
${ }^{28}$ Repito aqui a informação da edição adotada com respeito à lição desse termo, adota-se comumente "enérgeia", mas outra que é também aceita (por Racionero, por exemplo) é "enárgeia" que se traduz por "nitidez" - como já mencionamos, trata-se de um dos recursos estudados na presente pesquisa.
} 
ambos, na verdade, põem algo em evidência, bem como 'pois nós não terminamos guerras, mas adiamo-las'. Ambas remetem para o futuro, tanto o adiamento como este tipo de paz. (1411b)

Observa-se no excerto acima que a metáfora, ao provocar o efeito de visualização, pode remeter ao tempo presente quando dá certo movimento ao objeto metaforizado. Aqui temos também um tipo de metáfora que transforma o inanimado em animado, pois a "estátua implora". Da mesma maneira, ao falar do adiamento, remete-se ao futuro. Esse mecanismo de remeter para diversos tempos demonstra a capacidade que a metáfora tem de tornar visível, pois algo que acontecerá no futuro implica um processo de imaginação ${ }^{29}$, uma vez que o fato ainda não aconteceu e, tampouco, é presenciado naquele momento.

Mais adiante (cap. 11), Aristóteles conclui que as expressões elegantes provêm da metáfora de analogia e dessa disposição do objeto "diante dos olhos". Ele agora discorre acerca do "trazer diante dos olhos" (prò ommatón poiê̂n), esse resultado, na realidade, representa uma ação, o que nem sempre ocorre com a metáfora - é o caso de "um homem de bem é um quadrado"; aqui não há nenhuma ação. Aristóteles fornece inúmeros exemplos de representações de uma ação, em grande parte extraídos de Homero, os quais transformam o inanimado em animado, tais como "a flecha voou", "a ponta da arma penetrou, ansiosa, no peito" - os objetos inanimados aqui representam uma ação. Para resumir o procedimento, nada melhor que a proposição do próprio Aristóteles: "Pois o poeta atribui-lhes vida e confere-lhes também movimento; ora, movimento é acção." (1412a).

Aristóteles continua a tratar da elegância retórica e torna a afirmar que a metáfora deve vir de coisas apropriadas, porém, não óbvias, pois assim como na filosofia, o espírito sagaz é capaz de "estabelecer a semelhança mesmo com entidades muito diferentes". Entende-se então que a metáfora é elegante porque proporciona um aprendizado; por essa razão, ela reside no engano prévio do ouvinte, pois desse modo é possível perceber que se aprende algo, caso aquilo que se ouve seja o contrário do esperado.

Outros métodos podem produzir aprendizado, tais como os bons enigmas, já mencionados antes no tratado, que contêm tanto um ensinamento como uma metáfora; consequentemente, são agradáveis - isso ocorre, sobretudo, quando se apresenta algo

\footnotetext{
${ }^{29}$ Trata-se da phantasía, comumente traduzida como "imaginação", da qual logo trataremos.
} 
paradoxal, recurso presente nas anedotas ou no verso cômico. A homonímia pode criar este mesmo efeito sobre o ouvinte com o jogo de palavras. A antítese possibilita o aprendizado, que será mais rápido se a antítese for mais concisa. Os provérbios são considerados também um tipo de metafora, se entendermos o fato ao qual o provérbio remete e conseguirmos relacioná-lo com o fato ao qual é comparado. A hipérbole é também considerada metáfora quando o exagero implica uma relação de semelhança, por exemplo: "julgarias que ele era um cesto de amoras" ou "como a salsa, leva as pernas torcidas" (1413a).

Cabe ressaltar o que foi afirmado e reiterado diversas vezes por Aristóteles: a metáfora, juntamente com a antítese e a "representação de uma ação" diante dos olhos, é um recurso que facilita a aprendizagem e torna a expressão mais elegante.

\section{Cícero}

No livro III do De Oratore, Cícero também teoriza acerca da metáfora, §155-70, cujo termo latino é translatio, ao tratar dos recursos que são utilizados para ilustrar o discurso a partir das palavras isoladas. Apresento de maneira sucinta as principais asserções dessa passagem.

A definição de Cícero é essencialmente a mesma: a transferência de palavras, ou seja, o emprego de uma palavra a algum objeto, apesar dela não se referir propriamente a ele. A princípio isso se fez necessário por falta de termos próprios para algumas coisas, contudo - assim como as roupas, que antes eram utilizadas para combater o frio e passou a ser um ornamento para o corpo - sua função estendeu-se também ao deleite, conferindo brilho ao discurso.

A metáfora consiste numa breve comparação reduzida a uma palavra que, por sua vez, só deleitará se houver relação de similitude. Convém que a metáfora torne as coisas mais claras: ea transferri oportet, quae aut clariorem faciunt rem (§157).

Ainda que haja termos próprios para o que se quer dizer, as palavras transladadas deleitam mais se forem empregadas adequadamente. Cícero arrola algumas razões para esse fato, dentre as quais destacamos: não se perde o que escuta, pois é transportado para o pensamento; em uma única palavra funde-se o objeto e a comparação; ou ainda porque apresenta aos próprios sentidos, em especial à vista - o sentido mais agudo, §160: ad sensus ipsos admovetur, maxime oculorum, qui est sensus acerrimus. 
As metáforas que afetam a visão são muito mais vívidas, pois quase dispõem diante dos olhos da alma o que de fato não podemos ver. Não há nada na natureza que não possa ter outra nomenclatura baseando-se em relação com outras coisas. Quando se translada uma palavra, portanto, ela oferece luz ao discurso.

Os olhos da mente (mentis oculi) são movidos mais facilmente por aquilo que já se conhece pela visão do que por aquilo que se ouviu falar. A maior qualidade da metáfora é que a realidade transferida impressiona os sentidos, portanto, devem-se evitar os aspectos torpes da realidade que a similitude traz ao ânimo dos ouvintes.

A palavra que foi transferida não deve resultar em algo mais pobre do que o termo próprio; tampouco pode soar muito dura, é preciso suavizá-la. Dentre os recursos das palavras isoladas, não há procedimento mais florido nem que confira mais luz ao discurso do que a metáfora.

Por outro lado, a alegoria, procedimento derivado da metáfora, não se produz na palavra, mas no discurso, ou seja, com as palavras agrupadas. A alegoria articula-se em inúmeras metáforas contínuas, desse modo, ao dizer uma coisa se entende outra distinta. Isso ocorre porque as palavras próprias de um âmbito são transferidas para outro; tratase, portanto, de um grande ornamento que deve evitar a obscuridade, pois dessa maneira produziriam enigmas.

Uma palavra própria para o objeto pode ser substituída por outra própria para ornamentar, como é o caso de "Roma" no lugar de "romanos" - é o que denominamos metonímia, embora Cícero não mencione a nomenclatura. Esse procedimento ornamenta menos, mas nem por isso se deve ignorá-lo, é ainda capaz de estender a totalidade de algo a uma de suas partes - temos aqui a sinédoque.

Corre-se o risco da metáfora ser feita de forma não tão elegante quando transferimos frequentemente uma palavra que possui significado próximo ao termo próprio.

\section{Quintiliano}

Vejamos agora o tratamento dado à metáfora por Quintiliano, em VIII, VI ${ }^{30}$ :

4. Incipiamus igitur ab eo [tropos], qui cum frequentissimus est tum longe pulcherrimus, translatione dico, quae metaphorà Graece

\footnotetext{
${ }^{30}$ Tradução: MARTINS, P. "Tropos na Eneida e uma imagem metafórica”. In: MARTINHO, M. dos Santos (org.) - $1^{o}$ Simpósio de Estudos Clássicos. São Paulo: Humanitas. 2006, pp. 91-118.
} 
uocatur. Quae quidem cum ita est ab ipsa nobis concessa natura, ut indocti quoque ac non sentientes ea frequenter utantur, tum ita iucunda atque nitida, ut in oratione quamlibet clara proprio tamen lumine eluceat 5. Neque enim uulgaris esse neque humilis nec insuauis apte ac recte modo adscita potest. Copiam quoque sermonis auget permutando aut mutuando quae non habet, quodque est difficilimum, praestat ne ulli rei nomen deesse uideatur. Transfertur ergo nomen aut uerbum ex eo loco in quo proprium est, in eum in quo aut proprium deest aut translatu proprio melius est. 6. Id facimus, aut quia necesse est aut quia significantius esta ut (ut dixi) quia decentius. [...] 8. metaphora breuior est similitudo, eoque distat quod illa comparatur rei quam uolumus exprimere, haec pro ipsa re dicitur. Comparatio est, cum dico fecisse quid hominem 'ut leonem'; translatio, cum dico de homine 'leo est'.

4. Comecemos, pois, a partir daquele [tropo], que não só é o mais comum, como de longe, é o mais belo; digo translatio aquilo que em grego chama-se metaphorá, que, não só, é tão natural, quando ela mesma nos é permitida, que até os indoutos a utilizam amiúde sem perceber, mas é tão agradável e nítida que no discurso luminoso, ainda que com brilho próprio, ela ilumina. 5. Ela, adequada e corretamente procurada, nem pode ser trivial, nem vulgar, tampouco desagradável. Também, [a metáfora] aumenta o repertório da língua, põe à disposição palavras, permutando um termo por outro ou tomando emprestado aqueles que não existem para que coisa alguma não pareça carecer de um nome, o que é muito difícil. Transfere-se, pois, o nome ou o verbo do lugar que lhe é próprio para aquele lugar em que falta um próprio ou o metafórico é melhor que o próprio. 6. Isso fazemos ou porque é necessário, ou porque é mais significante ou (como disse) porque é mais decoroso. [...] 8. A metáfora é mais breve do que o símile, e deste dista porque este compara a uma coisa que desejamos exprimir, já aquela pela própria coisa diz-se. Comparação é quando digo que um homem faz 'como um leão'; metáfora quando digo acerca de um homem 'é um leão'.

A exposição é bastante clara, resta-nos pontuar algumas afirmações. Para Quintiliano a metáfora é o tropo mais comum e mais bonito, que pode ser empregado naturalmente ou mesmo utilizado por pessoas não doutas; é de tal modo agradável e elegante que brilha com luz própria no discurso. Se utilizada corretamente, a metáfora não será comum, humilde ou desagradável.

A metáfora torna o discurso mais eloquente com a troca e empréstimo de palavras, além disso, o que é mais difícil, produzindo nome para as coisas que não o têm: um nome é transferido do lugar que lhe é próprio para outro, onde não há um termo próprio ou mesmo o transferido é melhor. 
O procedimento metafórico deve ser adotado quando necessário para tornar mais claro ou mais decoroso o que se diz, contudo, caso não haja tais necessidades, a transferência é imprópria. É necessária, por exemplo, no caso de "durum hominem" ou "asperum hominem" (§6), pois não há termos próprios para expressar essa característica no temperamento.

Segundo Quintiliano a metáfora é um símile numa forma mais breve: o símile compara, ao passo que, na metáfora, o objeto de comparação é substituído pelo outro, por exemplo, quando se diz a respeito do homem "ut leonem", no símile, enquanto na metáfora é "leo est" - mesmo exemplo observado em Aristóteles.

Logo em seguida, a partir do §9, ele apresenta a classificação da metáfora, que é de quatro tipos: a substituição de seres animados por outro animado (rebus animalibus... pro alio); seres inanimados por outro inanimado (inanima pro aliis generis); o inanimado substituído por seres animados (pro rebus animalibus inanima); por fim, seres animados por inanimados (aut contra).

Os efeitos são sublimes em decorrência do uso de uma metáfora audaz e arriscada e igualmente quando conferimos ação e espírito às coisas inanimadas, é o que ocorre em "Pontem indignatus Araxes" (Eneida, VIII, 728), aqui o rio se indigna, ou seja, lhe é atribuído uma característica humana. Inserida nessa classificação, há outras espécies: de seres racionais para racionais e de irracionais para irracionais, e assim reciprocamente, dos racionais para irracionais ou dos irracionais para os racionais, o mesmo ocorre com as partes e o todo.

Quintiliano descreve alguns aspectos negativos da metáfora em razão do uso inadequado; a partir do §14, ele afirma que o uso moderado e oportuno ilustra a oração, entretanto, se usado excessivamente, obscurece e causa tédio. No caso do uso contínuo, resulta em alegorias e enigmas. A metáfora pode ser pobre ou mesmo grosseira, pode ainda ser áspera quando está distante da relação de semelhança. A metáfora deve adequar-se ao assunto referido, não pode ser excessivamente maior ou, como é mais frequente, menor, ou mesmo dessemelhante - tudo isso é vicioso. A abundância no seu uso é também viciosa, sobretudo se for da mesma espécie.

Aos poetas é permitido usar muitos recursos para deleitar ou pela necessidade do metro. Entretanto, isso não convém à prosa, por essa razão, mesmo exemplos extraídos de Homero não são aconselháveis. Ainda assim, observamos que Quintiliano fornece, com recorrência, exemplos de Cícero, reforçando o preceito aristotélico de que a metáfora pode ser adotada na prosa. 
A metáfora deve ocupar um lugar vago, mas no caso de ocupar o de outro, deve ser mais eficiente do que aquilo que retira $(\$ 18)$.

Alguns dos aspectos mencionados acima se aplicam também à sinédoque: a metáfora deve mover os ânimos, destacando as coisas que são obtidas diante dos olhos, a sinédoque também permite ao público a percepção de muitas coisas a partir de uma única mencionada, com a diferença de que pode ser usada mais livremente na poesia e na prosa.

Lembramos ainda a definição de translatio na Retórica a Herênio, livro IV, 45, anterior a Quintiliano: ela ocorre quando a palavra é transferida de uma coisa a outra em razão de sua semelhança. Tal procedimento pode ser adotado para pôr algo diante dos olhos, para abreviar, para evitar uma obscenidade, para amplificar, para minimizar e para ornamentar. A metáfora deve ser comedida, de maneira que não se desvie para algo dissímil.

Quintiliano trata do símile no mesmo livro, capítulo III, $72-5^{31}$ :

72. Praeclare uero ad inferendam rebus lucem repertae sunt similitudines; quarum aliae sunt, quae probationis gratia inter argumenta ponuntur, aliae ad exprimendam rerum imaginem compositae, quod est huius loci proprium:

Inde lupi ceu

Raptores atra in nebula

Et

Aui similis, quae circum litora, circum

Piscosos scopulos uolat aequora iuxta,

73. Quo in genere id est praecipue custodiendum, ne id, quod similitudines gratia adsciuimus, aut obscurum sita ut ignotum. Debet enim, quod illustrandae alterius rei gratia assumitur, ipsum esse clarius eo quod illuminat. Quare poetis quidem permittamus sane eiusmodi exempla:

Qualis ubi hibemam Lyciam Xanthique fluenta

Deserit aut Delum maternam inuisit Apollo.

Non idem oratore decebit, ut ocullis aperta demonstret. 74. Sed illud quoque, de quo in argumentis diximus, similitudinis genus ornat orationem facitque sublimem, floridam, iucundam, mirabilem. Nam quo quaeque longius perita est, hoc plus 75. adfert nouitatis atque inexpectata magis est.

\footnotetext{
${ }^{31}$ Tradução de Paulo Martins. Cf. nota 30.
} 
72. Os símiles (comparações) são invenções certamente brilhantes que servem para oferecer luz aos pensamentos. Alguns deles são propostos em função da prova de argumentos; outros, para representar a imagem dos pensamentos dispostos. Esse é o seu lugar apropriado:

'Daí os lobos como

Raptores em negras nuvens'

E

'Semelhante às aves que sobrevoam os litorais

E os peixes dos rochedos, humilde voa junto ao mar'

73. Deve ser observado precisamente neste tipo de ornato o que, graças ao símile, assumimos para que ele não seja obscuro ou desconhecido. Pois, o que é selecionado com intuito de ilustrar outro pensamento, deve ser mais claro do que aquilo que ele ilumina. Porque, então, permitamos sempre aos poetas exemplos desse tipo:

Como Apolo quando abandonou a hiberna Lícia

E o fluente Xanto, visitou a Delos materna.

Não será conveniente ao orador fazer o mesmo para que o claro demonstre por [símiles] obscuros. Mas aquele tipo de símile, sobre o qual dissemos que estão ligados aos argumentos, também orna o discurso e o faz sublime, florido, agradável e admirável, pois quanto mais distante o símile esta daquele a que é aplicado, mais novidade ele traz e mais inesperado que ele é.

O símile tem como função oferecer luz aos pensamentos (ad inferendam rebus lucem) servindo não apenas como ornato, mas também contribuindo para a argumentação. Haveria, portanto, dois tipos de símile: um poético, que funciona como ornato, e outro oratório, como argumentação ${ }^{32}$.

$* * *$

Após breve discussão acerca da metáfora, podemos esboçar um paralelo entre a teoria que lhe é concernente em Aristóteles, Cícero e Quintiliano. Não é preciso discutir a respeito da definição de metáfora, pois todos afirmam praticamente o mesmo: trata-se

\footnotetext{
${ }^{32}$ A distinção está bem explicada no artigo citado na nota 30: "Outra observação é a distinção entre um símile poético e um oratório, enquanto o primeiro serviria apenas ao ornamento (ornatus) e, portanto, associado à elocução (elocutio); o segundo serviria à argumentação (argumentatio) e, portanto, ligado à disposição (dispositio). Tanto esta dicotomia, como aquela conclusão de Aristóteles de que a metáfora é mais poética do que o símile devem ser minimizadas, pois é certo que, frequentemente, encontramos um símile dentro do discurso oratório que sirva apenas ao ornato, como, também, dentro da poesia funcionando apenas como amplificação da argumentatio. Talvez, fosse interessante pensar que ambos tropos (símile/similitudo e metáfora/ translatio) tanto na poesia como na prosa operam, simultaneamente, na elocução como ornato e na disposição como argumentatio, pois, não devem ser incompreensíveis a ponto de obscurecer tanto uma como outra e os dois devem servir como amplificação da imagem que se ilustra, apontando o discurso para o admirável, o sublime, o agradável e o florido." (pp.5)
} 
de um tropo que transporta uma palavra para o lugar de outra, desviando-se de seu significado próprio.

Em Aristóteles, o recurso metafórico é um tipo de ornamento que pode ser adotado também no discurso retórico porque consegue manter a clareza do discurso e conferir um caráter diferenciado a ele; ainda assim, não é recomendável que se utilize quaisquer tipos de ornamentos na prosa, pois não é apropriado. A metáfora tem essa capacidade de clarificar o discurso; outros, no entanto, poderiam obscurecê-lo. A metáfora contribui também para a produção de conhecimento e para certo afastamento da linguagem comum e, consequentemente, agrada o público.

Para Quintiliano, a metáfora torna o discurso mais eloquente e agradável; porém, aos prosadores não é permitido abusar dos ornamentos como os poetas o fazem, o excesso da metáfora é vicioso e obscurece o discurso, culminando em alegorias ou enigmas; deve-se então utilizá-la moderadamente. Ambos concordam que a metáfora é largamente utilizada na prosa, mas mesmo assim, a ornamentação em geral não é própria da prosa.

Em resumo, na Retórica, as funções que predominam na metáfora são agradar e ensinar. Além da necessidade, Cícero destaca a capacidade de ornamentação da metáfora que, portanto, é fundamental para deleitar, destaca ainda a capacidade de impressionar os sentidos, portanto, também comove. Em Quintiliano, predomina também o deleite; contudo, a outra função que lhe é atribuída é mouere, uma vez que isso se torna mais fácil com a visualização do discurso. Nesse caso, a capacidade que a metáfora tem de tornar visível seu objeto é o aspecto que afeta o público, pois sabemos que o ouvinte é mais facilmente comovido por aquilo que vê do que pelo que ouve. Aristóteles corrobora esse resultado da metáfora de "trazer diante dos olhos", mas não discute acerca da comoção que pode provocar, e o deleite é para ele produzido em razão da linguagem mais solene.

A relação com o símile (eikòn), inevitável, é operada por Aristóteles e Quintiliano, no entanto, aquele diz que o símile é um tipo de metáfora, ao passo que, este, afirma que a metáfora é uma forma mais curta do símile, o qual se enquadra nas figuras de pensamento. A grande diferença está na classificação: Aristóteles propôs na Poética a tipologia que toma como base o gênero e espécie das coisas que são relacionadas, com destaque para a analogia, pois esta parece mais eficaz no processo de visualização do conteúdo mencionado. Contudo, no tratado retórico, pode-se entrever um dos tipos de Quintiliano - a transformação do inanimado em animado - o que 
demonstra não haver uma tipologia estabelecida. Em Quintiliano, o princípio de classificação da metáfora reside nos seres animados e inanimados. Cícero também deixa entrever o parentesco entre metáfora e símile ao declarar que se trata de uma comparação reduzida e sua função só se cumprirá se houver de fato similitude com o objeto metaforizado.

$\mathrm{Na}$ doutrina aristotélica, diversos procedimentos podem ser associados à metáfora; basta que o procedimento permita estabelecer uma relação de semelhança - é o que pode ocorrer nos enigmas, na homonímia, na antítese, nos provérbios e nas hipérboles.

Para Cícero, a alegoria pode culminar em enigmas se obscurecer o discurso. Aqui parece ser considerado como algo negativo, ao contrário de Aristóteles, que afirma que os bons enigmas veiculam metáforas e proporcionam aprendizado. Cícero ainda destaca a metonímia como um tipo de metáfora, na qual temos inserida a sinédoque.

Em Quintiliano, não há tamanha profusão de procedimentos, mas ele relaciona o recurso metafórico à sinédoque, pois carrega o significado de muitas coisas a partir de uma única. Seguindo o aspecto primeiro da metáfora, pode-se entender que ambas se desviam do significado que lhe é próprio para representar algo. $\mathrm{O}$ enigma é também mencionado por Quintiliano como resultado do uso excessivo da metáfora, juntamente com a alegoria, corroborando o caráter negativo do enigma. A alegoria constitui-se como uma metáfora num âmbito maior, o do discurso, e o enigma é a alegoria obscura; portanto, a relação entre tais figuras e a metáfora parece inevitável.

Os procedimentos que resultam na visualização são característicos da amplificação no discurso. Aristóteles menciona por duas vezes a relação da metáfora com a amplificação: no capítulo 6, do livro III, 1408a, relacionando um objeto com características que ele não possui, de maneira a enaltecê-lo ou diminuí-lo; vemos também em um exemplo no capítulo 10, 1411b, no qual o esforço implica a amplificação. Embora Quintiliano não fale diretamente da amplificação ao tratar da metáfora, em VIII, IV, 3, ele insere a comparação como um dos métodos da amplificação. Além disso, percebe-se a proximidade de sua teoria com a de Cícero, não apenas nas definições, mas também nos reiterados exemplos que extrai dos discursos deste para ilustrar suas proposições. Vimos que Cícero tratou da questão da amplificação no De Partitione Oratoria e também no De Oratore, onde é considerada um recurso que contribui para a visualização do discurso, visto que a amplificação permite ressaltar o que se diz. 


\section{I.3. FANTASIA}

\section{Platão}

O uso conhecido mais antigo do termo fantasia ${ }^{33}$, acredita-se, está na República de Platão, livro II, 382e, onde "fantasma" é usado com o mesmo sentido um pouco antes nesse diálogo (382a2) ao tratar da ilusão que os deuses podem provocar apresentando-nos coisas falsas, processo que resulta em tais fantasias ou phantásmata (plural de phántasma). O termo phantásmata aparece na passagem do livro VI, quando Platão define o mundo visível e o inteligível, onde se refere às imagens que são produzidas na superfície das águas e de outros corpos. Destaco a seguir tais passagens ${ }^{34}$ :

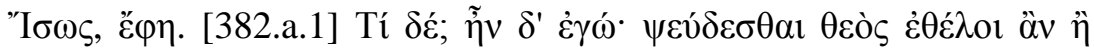

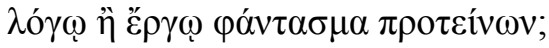

Como? Perguntei: dispor-se-á algum deus a mentir, por atos ou por palavras, e a representar-nos uma imagem falsa (phántasma) de si mesmo? (382a)

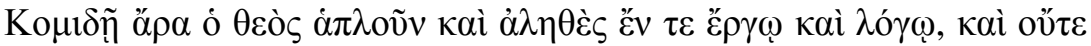

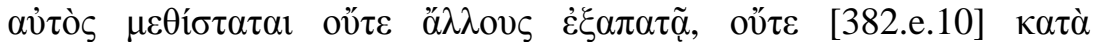

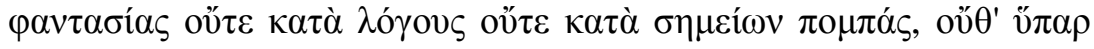
oủ $\delta$ 'o

[...] Logo, Deus é perfeitamente simples e veraz, tanto em atos como em palavras, e não só não muda de forma como não engana os outros por meios ilusórios (phantasías) ou por discursos, nem por sinais de sua parte durante o sono ou na vigília. (382e)

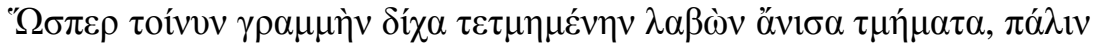

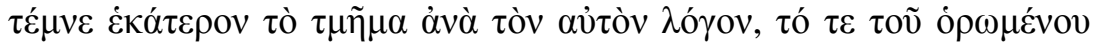

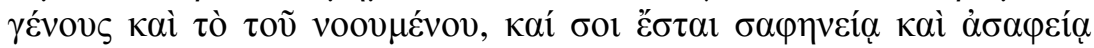

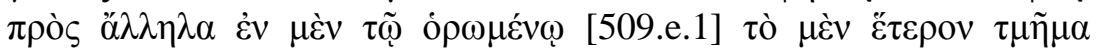

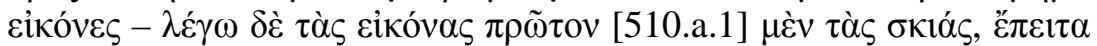

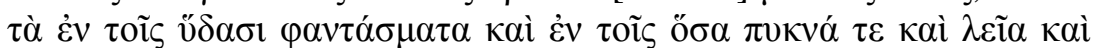

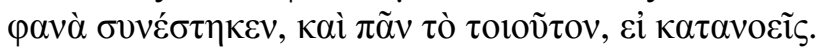

\footnotetext{
${ }^{33}$ Cf. afirmação em: BARNOUW, J. Propositional Perception. Oxford: University Press of America. 2002 - Texto que serve também como referência para nosso estudo da fantasia em Aristóteles; WATSON, G. "The Concept of 'Phantasia' from the Late Hellenistic Period to Early Neoplatonism”. In: Rise and Decline of the Roman World. Berlin/ New York: Walter de Gruyter. 1994. Parte II, pp.47654810.

${ }^{34}$ Edição adotada: tradução de Carlos Alberto Nunes. Pará: Editora Universitária UFPA. 2000. $3^{\text {a }}$ edição.
} 
Sendo assim, imagina uma linha cortada em duas partes desiguais, a qual dividirás, por tua vez, na mesma proporção: a do gênero visível e a do inteligível. Assim, de acordo com o grau de clareza ou obscuridade de cada uma, acharás que a primeira seção do domínio do visível consiste em imagens. Dou o nome de imagens, em primeiro lugar, às sombras; depois, aos simulacros (phantásmata) formados na água e na superfície dos corpos opacos, lisos e brilhantes, e a tudo mais do mesmo gênero, se é que me compreendes. (509e - 510a)

Na primeira passagem, o conceito de fantasma significa algo como "aparência", cuja tradução adotada designa por "imagem falsa". Platão quer mostrar que os deuses jamais iludiriam os homens com coisas falsas, aqui representadas por fantasias, pois eles não admitem nenhum gênero de mentira, censurando os poetas que as transmitem ou que tratam os deuses como mentirosos, desaconselhando o emprego de tais composições na educação dos jovens.

Quanto à teoria da linha que divide o mundo visível e o inteligível, bastante conhecida, também se remete ao fantasma: da mesma forma que a luz e a visão podem ser comparadas com o sol, mas não podem ser identificadas com ele, o conhecimento e a verdade são semelhantes à ideia do bem, mas não lhe são idênticos, pois o bem é muito maior. Portanto, os objetos do mundo visível têm seus correspondentes nas imagens (eikónes), que incluem as sombras e os fantasmas, estes, por sua vez, englobam os reflexos que tais objetos produzem.

O termo aparece também no diálogo Teeteto $^{35}$, na teorização acerca do conhecimento, 152c:

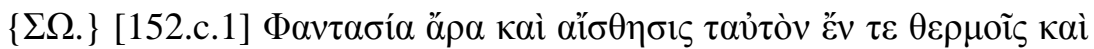

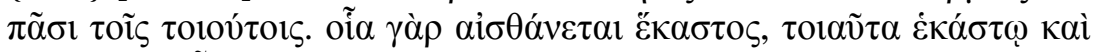

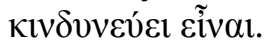

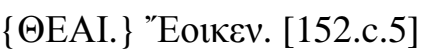

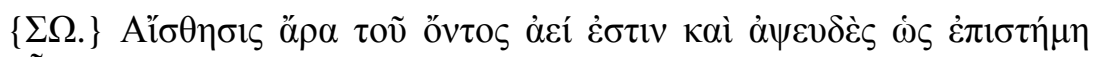
oṽ $\sigma \alpha$.

Sócrates: Então aparição (phantasía) e percepção são a mesma coisa no que toca ao calor e todas as coisas desse tipo. Conclui-se que como cada indivíduo percebe as coisas, assim são elas para cada indivíduo.

Teeteto: Sim, isso parece exato.

\footnotetext{
${ }^{35}$ Edição adotada: Diálogos I. Tradução de Edson Bini. São Paulo: Edipro. 2007.
} 
Sócrates: A percepção, portanto, é sempre daquilo que existe, e posto que é conhecimento, não pode ser falsa.

Na passagem em que trata da definição de conhecimento, a percepção (aisthesis) e a fantasia são equivalentes, pois as coisas são percebidas de maneira distinta por cada indivíduo. Podemos, por exemplo, pensar na temperatura - o frio pode variar, pois algumas pessoas julgam sentir frio ao mesmo tempo em que outras não sentem. Logo, as coisas são tomadas pela pessoa como correspondentes às características imediatamente sentidas e produz uma ideia para elas - nisso se constitui a fantasia. Seguindo essa lógica, a percepção é também conhecimento, pois depende do conhecimento que o indivíduo tem acerca do objeto; portanto, não pode ser falsa.

Mais adiante, ainda em Teeteto, os sentidos são instrumentos destinados aos objetos de percepção (184d), é preciso, contudo, que os sentidos se reúnam em uma faculdade, que pode ser considerada a alma, servindo como intermediária do processo de percepção. As sensações provenientes do corpo são percebidas tanto por homens como por animais desde seu nascimento; as reflexões sobre tais sensações, com relação a sua existência e utilidade, contudo, surgem lentamente, por meio da educação. O conhecimento não está presente então nas sensações, mas no processo de reflexão acerca delas (186c) - a existência e a verdade podem ser apreendidas pelo raciocínio e não pela sensação. Em 186d, conclui-se que a percepção não pode ser entendida como conhecimento, em razão mesmo do caráter subjetivo desta que, como vimos, pode parecer diferente para cada um.

A opinião (dóxa) verdadeira pode ser considerada conhecimento, mas a falsa opinião não (187b). Para compreender a definição de opinião, antes se deve entender o que é o pensamento (diánoia): é a conversa silenciosa que a alma tem com ela mesma, questionando e respondendo acerca de um assunto, afirmando e negando consigo, mas quando se chega a uma conclusão, chamamos isso de opinião (189e-190a).

Em 191c-194d do mesmo diálogo, imagina-se que a alma é como uma tábua de cera $^{36}$ :

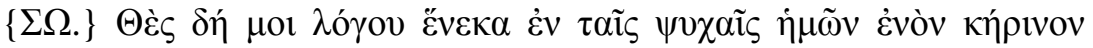

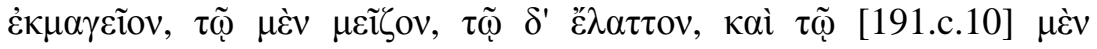

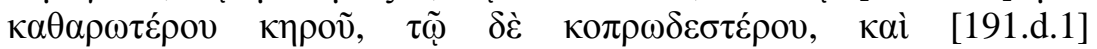

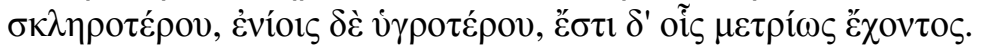

\footnotetext{
${ }^{36}$ Cf. nota 35.
} 


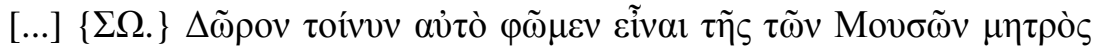

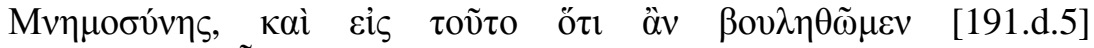

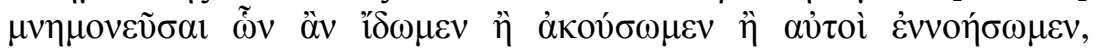

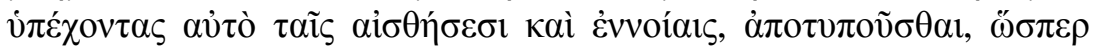

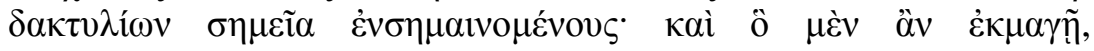

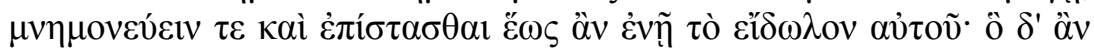

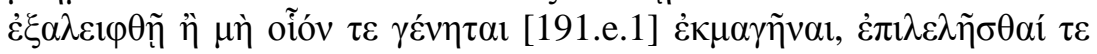

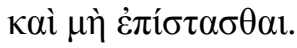

Sócrates: Agora, quero que suponhas - a favor do argumento - que há um bloco de cera em nossas almas, num caso maior, em outro menor; num caso, cera mais pura, em outro, cera mais impura e dura; em outros casos, mais mole; e, em alguns casos, da qualidade adequada.

[...] toda vez que desejamos nos lembrar de qualquer coisa que vemos, ouvimos e concebemos em nossas próprias inteligências colocamos essa cera sob as percepções e pensamentos e a imprimimos nela, tal como produzimos impressões de anéis de sinete; e, seja o que for impresso, nós o lembramos e o conhecemos enquanto durar sua imagem, ao passo que tudo o que for apagado ou que não for possível imprimir esquecemos e não conhecemos. (191c-e)

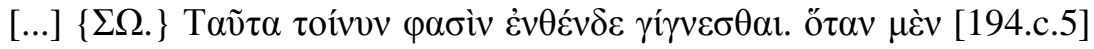

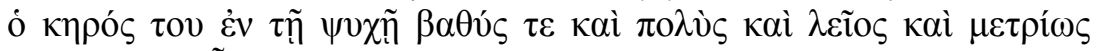

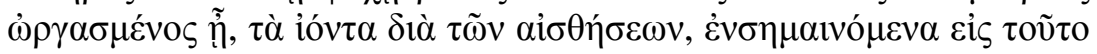

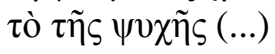

[...] Dizem que a causa dessas variações é a seguinte: toda vez que a cera da alma de um indivíduo é profunda, copiosa, lisa e na consistência apropriada, as imagens que ocorrem através das percepções são impressas sobre esse peito da alma (...). (194d)

A alma recebe as impressões daquilo que é percebido; então, quando alguém percebe algo que já conhece, produz uma espécie de imagem mental (eídolon); tal impressão é a marca da percepção. No entanto, a imagem que não permanecer será esquecida e não impressa, logo, não se terá conhecimento a respeito dela. A cera da alma do homem que for profunda, copiosa e lisa, imprime as imagens obtidas das percepções no "coração da alma" (to kéar), desse modo, as impressões também são profundas e perduram.

No Sofista, 263d-264d, Platão menciona que o pensamento, a opinião e a fantasia podem ocorrer como falsas ou verdadeiras na alma. Aqui temos a classificação de fantasia entendida dentro de uma tríade em parte mencionada no Teeteto $(189 \mathrm{e}-$ 190a): o pensamento é o mesmo que discurso (lógos), com a particularidade de que o pensamento é uma conversa silenciosa no interior da alma com ela mesma; o discurso 
também é proveniente da alma, com a diferença de "sair da boca"; este, por sua vez, contém afirmação e negação, que surge do pensamento: é o que se define como opinião; quando a opinião não surge naturalmente, mas por meio da percepção (di' aisthéseos), chamamos de fantasia. Logo, a fantasia depende da percepção que cada um tem dos objetos.

Notamos que as conclusões do Sofista são semelhantes ao que já fora proposto no Teeteto a respeito dos elementos que compõem a fantasia, processo que depende da opinião, do pensamento e também da percepção.

Já observamos anteriormente que Platão trata dos tipos de imitação, demonstrando que uma é baseada na semelhança e a outra aparenta semelhança; o sofista adota esse último; logo, como o diálogo se volta para a condenação dos artifícios utilizados pelo sofista para enganar as pessoas, a fantasia é também condenada. Embora não use nessa passagem (235d - 236c) a palavra "phantasía", o termo "phántasma" significa o mesmo nesse contexto, pois nos remete ao procedimento da fantasia - o que se produz é um simulacro do objeto representado, comprometendo o caráter de imagem do objeto.

Conclui-se, portanto, que Platão não aprova tal recurso, uma vez que produz impressões falsas. Sabemos que a teoria platônica é permeada pela desconfiança nos sentidos e o sentido da visão é exemplo clássico disso, uma vez que o mundo das ideias não pode ser visto, o que vemos é apenas uma representação dele.

\section{Aristóteles}

Embora o conceito da fantasia já estivesse presente na obra platônica, Aristóteles é quem nos fornece sua teorização no De Anima, III, 427b-428b ${ }^{37}$ :

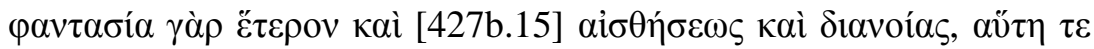

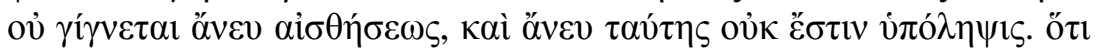

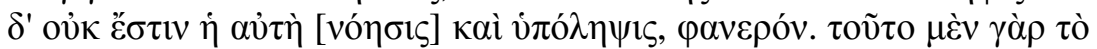

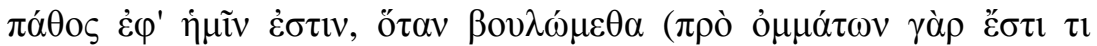

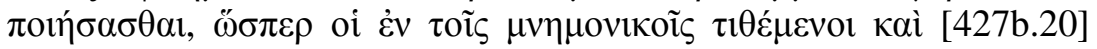
$\varepsilon i \delta \omega \lambda$ o

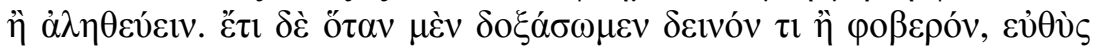

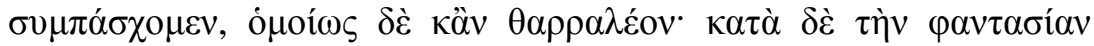

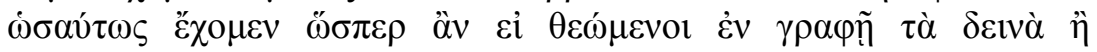

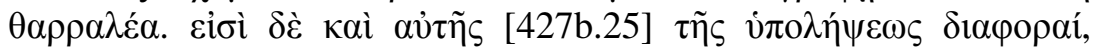

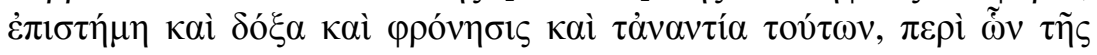

\footnotetext{
${ }^{37}$ Edição adotada: Tradução de Maria Cecília Gomes dos Reis. São Paulo: Editora 34. 2006.
} 


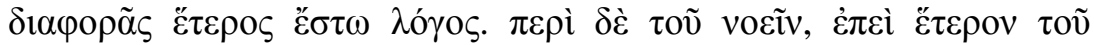

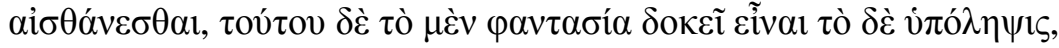

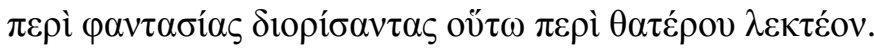

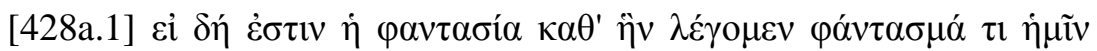

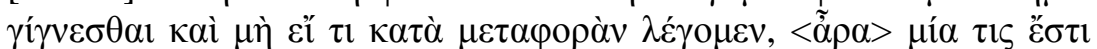

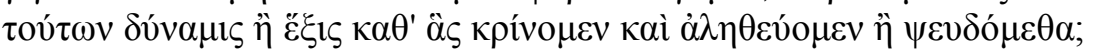

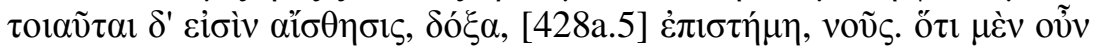

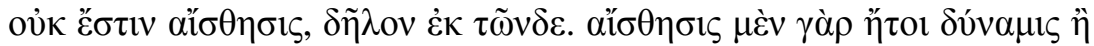

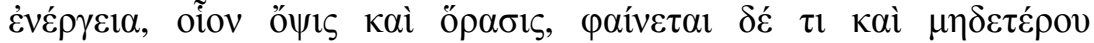

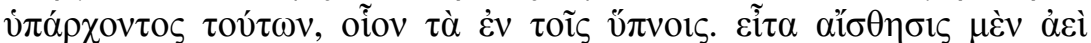

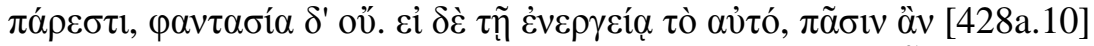

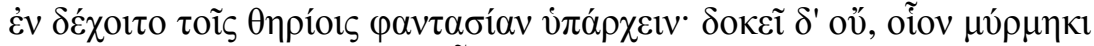

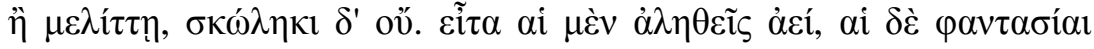

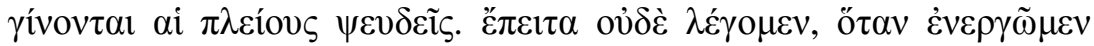

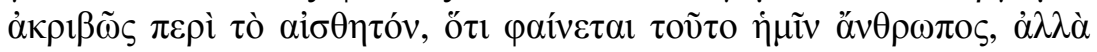

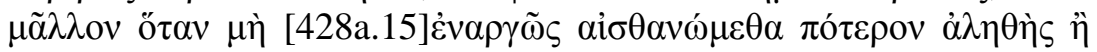

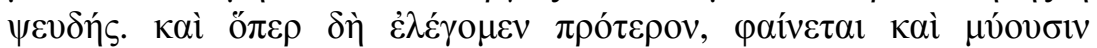

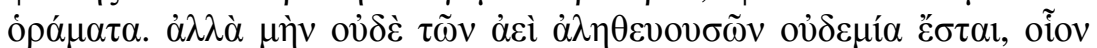

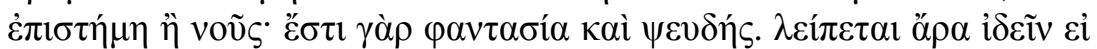

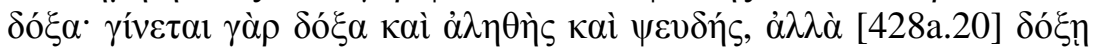

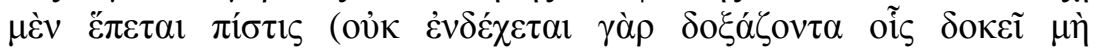

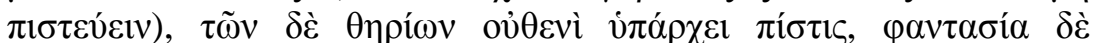

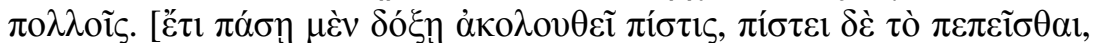

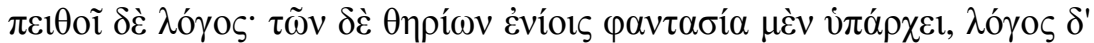

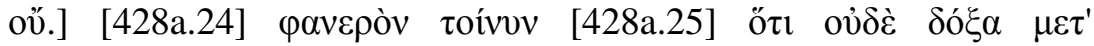

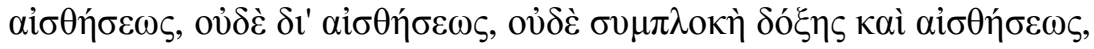

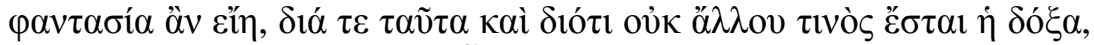

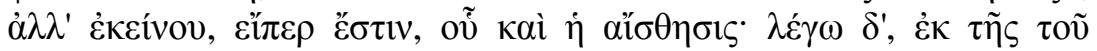

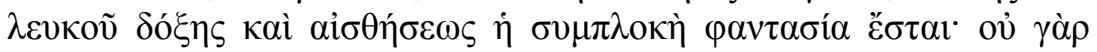

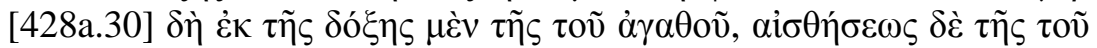

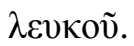

Pois a imaginação ${ }^{38}$ (phantasía) é algo diverso tanto da percepção sensível como do raciocínio; mas a imaginação não ocorre sem percepção sensível e tampouco sem a imaginação ocorrem suposições. É evidente que a imaginação não é pensamento e suposição. Pois essa afecção depende de nós e do nosso querer (pois é possível que produzamos algo diante dos nossos olhos, tal como aqueles que, apoiando-se na memória, produzem imagens), e ter opinião não depende somente de nós, pois há necessidade de que ela seja falsa ou verdadeira. Além disso, quando temos a opinião de que algo é terrível ou pavoroso, de imediato compartilhamos a emoção, ocorrendo o mesmo quando é encorajador. Porém, se é pela imaginação, permanecemos como que contemplando em uma pintura coisas terríveis e encorajadoras.

[...] E a respeito do pensar, visto que ele é diverso do perceber, e como ele parece ser por um lado imaginação, mas por outro concepção, devemos tratar desta após termos definido a imaginação. Se a imaginação é aquilo segundo o que dizemos que nos ocorre uma imagem - e não no sentido em que o dizemos por metáfora -, seria ela

38 "Imaginação" é o termo normalmente adotado pelos teóricos para se referir à fantasia aristotélica. 
então alguma daquelas potências ou disposições segundo as quais discernimos ou expressamos o verdadeiro ou o falso? Deste tipo são a percepção sensível, a opinião, a ciência e o intelecto. 428a. Que a imaginação não é percepção sensível, é evidente a partir disto: pois a percepção sensível é ou uma potência como a visão ou uma atividade como o ato de ver; mas algo pode aparecer para nós mesmo quando nenhuma delas subsiste - como, por exemplo, as coisas em sonhos. Além disso, a percepção sensível está sempre presente, mas não a imaginação. E se ela fosse o mesmo que a percepção sensível em atividade, então seria possível subsistir imaginação em todas as feras; mas não parece ser assim, por exemplo, nas formigas, abelhas e vermes. Depois, as percepções sensíveis são sempre verdadeiras e a maioria das imaginações é falsa. Além disso, quando estamos em atividade acurada no que concerne a um objeto perceptível, não dizemos que ele aparenta ser um homem, mas antes quando não o percebemos claramente. É neste caso que a percepção seria verdadeira ou falsa. E, como já dissemos, imagens aparecem para nós mesmo de olhos fechados.

A intelecção (nóesis/ to noeîn), ou pensamento como adotado na tradução, e a percepção (aisthesis) não são iguais, uma vez que a percepção é sempre verdadeira e todos os animais possuem. Quanto ao pensamento ou raciocínio (diánoia), este pode ser falso e nenhum animal sem razão (lógos) pode tê-lo; a fantasia é distinta da percepção e do pensamento, mas não ocorre sem a percepção, tampouco a suposição (hypólepsis) pode ocorrer sem a fantasia.

A fantasia não é simplesmente intelecção e suposição, pois o pensamento depende da vontade, é possível elaborar imagens (eidolopoioûntes - 427b20) diante de nossos olhos, assim como nos exercícios mnemônicos, ao passo que opinar (doxázein) não depende de nós, pois a opinião deve ser falsa ou verdadeira. A opinião que fazemos de algo nos desperta a emoção correspondente à visão com grande força, a fantasia, porém, não produz tamanho efeito - é como se estivéssemos diante de pinturas que tratam de tais questões, mas sem provocar a mesma emoção.

A fantasia ocorre com o surgimento de uma imagem (phántasma), excluindo-se o uso metafórico, portanto, Aristóteles propõe um questionamento: poder-se-ia dizer que se trata de uma das potências ou disposições que nos permitem discriminar o que é verdadeiro ou falso? Tais potências são: a percepção, a opinião, o conhecimento e a inteligência. No entanto, não pode ser percepção, pois esta é uma potência ou uma atividade - vista ou visão, uma imagem pode manifestar-se mesmo quando não está 
presente nenhuma das duas, é o caso dos $\operatorname{sonhos}^{39}$. A percepção está sempre presente, a fantasia não. Se a fantasia fosse como a atividade da percepção então ela ocorreria para todos os animais, mas não ocorre; além disso, tais atividades são sempre verdadeiras, enquanto a maior parte das fantasias é falsa. No caso da percepção, somente quando não é clara, pode ser verdadeira ou falsa. Aristóteles reitera aqui que as visões podem ocorrer mesmo com os olhos fechados (428a).

A fantasia também não pode ser como o conhecimento ou a inteligência, pois eles acompanham a verdade sempre e, como já sabemos, a fantasia pode ser falsa. Resta-nos, ainda, a opinião: uma vez que essa pode ser verdadeira ou falsa, está acompanhada sempre de convicção (pístis); porém, mesmo que muitos animais tenham a fantasia, não possuem a convicção, pois toda convicção acompanha a persuasão que, por sua vez, é acompanhada pela razão (lógos), que não está presente em alguns animais. Portanto, a fantasia não é opinião junto à percepção (dóxa met'aisthéseos 428a25) ou mesmo por meio da percepção (di'aisthéseos), tampouco uma mistura de ambos (sumplokè dóxes kaì aisthéseos - 428a25-6).

A teoria platônica afirma que a fantasia trata-se da combinação da percepção, da opinião e do pensamento - relação também estabelecida por Aristóteles (Sofista, 263d264d). Observamos no De Anima que a fantasia se originaria da opinião que surge por meio da percepção, mas como um processo que independe da vontade, enquanto o pensamento é um mecanismo movido pela vontade. A imagem produzida pela opinião seria mais impactante do que as produzidas somente pelo pensamento.

Já é possível identificar aqui dois tipos de fantasia que serão expostas mais adiante no tratado: a perceptiva e a deliberativa (434a5). A perceptiva subsiste nos homens e também em outros animais, ao passo que a deliberativa existe apenas naqueles que são capazes de calcular, raciocinar. A fantasia deliberativa - ou raciocinativa, conforme mencionado um pouco antes (433b21) - permite produzir uma imagem a partir de várias, por essa razão, acredita-se que a fantasia não envolve a opinião, porque essa não se forma por inferências, mesmo assim, a opinião envolve a fantasia.

Imaginar é opinar precisamente a respeito do objeto da percepção, não acidentalmente, no entanto, imagens falsas também podem manifestar-se, mesmo que a

\footnotetext{
${ }^{39}$ Cf. Do Sonho [Perì Enypníon]. 459a: Aristóteles ressalta a relação entre sonho e as faculdades imaginativa (to phantastikón) e da percepção (tôi aisthetikôi), ainda que sonhar não seja propriamente da percepção, como se insere durante o sono, que é uma experiência da faculdade perceptiva, associa-se à percepção de alguma maneira. Além disso, a fantasia é um processo ocasionado pela percepção em estado de atividade e como o sonho aparenta ser um tipo de phántasma, pois é como se chamam as imagens durante o sono, sonhar pertence também à faculdade imaginativa.
} 
concepção seja verdadeira, é o caso do sol: ele parece pequeno, acredita-se, porém, que seja maior do que a terra - dessa maneira se perde a opinião verdadeira, mas sem esquecê-la, persistindo nessa opinião, ela teria que ser verdadeira e falsa ao mesmo tempo, mas torna-se falsa quando não percebemos que sua condição muda (428b).

Conclui-se, portanto, que a fantasia não é uma dessas potências, tampouco existe a partir delas.

A fantasia parece ser um movimento (kínesis) relacionado à percepção que só pode ocorrer naqueles que a possuem: sob a influência da percepção se produz o movimento e sofrerá muitas coisas de acordo com ele, que pode ser tanto verdadeiro como falso. A percepção comporta o mínimo de falsidade; no entanto, é possível enganar-se acerca do conceito que se faz do objeto da percepção de características próprias (tais como tamanho e movimento), a respeito das quais a percepção se engana. Vale lembrar aqui a classificação feita no mesmo tratado, livro II, 418a, em que há três tipos de características que podem ser percebidas nos objetos: próprio - aquilo que não pode ser percebido por outro sentido, a respeito do qual não pode haver engano (a visão de cor, audição de som etc); comum - não é próprio de algum sentido (como o movimento, número, magnitude), o movimento, por exemplo, é perceptível tanto pelo tato como pela visão; acidental - uma característica percebida acidentalmente que serve para associar a um conceito não percebido pelo sentido, como a identidade de alguém.

O movimento operado pela percepção das características próprias quando o objeto está presente é verdadeiro, ao passo que a percepção das demais características pode ser falsa, principalmente quando o objeto sensível está distante.

Logo, se nenhum outro item comporta as características mencionadas, a fantasia seria o movimento originado pela percepção em atividade. E, como a visão é o principal sentido, a fantasia tomou o nome da "luz", pháos, pois não é possível ver sem luz.

Para concluir, os animais agem de acordo com as fantasias, uma vez que elas perduram e são semelhantes às percepções: alguns animais porque não possuem inteligência e outros porque a inteligência é às vezes encoberta pela emoção, por doenças ou pelo sono, é o caso dos homens.

A memória, segundo Aristóteles em seu tratado De Memoria, I, 449b, é um estado (éxis) ou afecção (páthos) da percepção ou da suposição no decorrer do tempo. Evidentemente, não há memória de algo que ocorre no presente; no entanto, a percepção ocorre no presente; quanto ao futuro, temos a expectativa, e a memória remete-se ao passado, de maneira que apenas os seres com consciência do tempo podem de fato 
recordar. A memória precisa produzir um fantasma, pois essencialmente pertence à faculdade da percepção; embora pareça pertencer ao pensamento, é possível verificar tal relação considerando que não apenas os homens e outros seres capazes de manifestar opinião e de pensar que apresentam a memória, pois ela se manifesta em muitos outros animais. A particularidade é que o homem tem consciência do tempo quando recorda algo. Logicamente, a memória pertence à mesma parte da alma a que a fantasia pertence, os objetos da fantasia são também objetos da memória. É possível lembrar-se de algo ausente se a afecção estiver presente: a afecção é produzida na alma por meio da percepção, o estímulo produzido imprime um tipo de semelhança da percepção (450a).

Na Metafísica, I, 980a-981b, Aristóteles começa discorrendo a respeito da utilidade da percepção para o conhecimento do homem, pois queremos sempre aprender e a preferência recai sobre a visão, pois mesmo quando não fazemos algo, este sentido nos permite conhecer as coisas que estão diante de nós. Todos os animais são dotados de sentidos; no entanto, não são todos que possuem memória; somente pela memória é possível recordar as experiências e com elas aprender. Alguns animais vivem com as imagens (phantasíai) e as recordações, mas não participam tanto da experiência quanto os homens, pois estes possuem a arte e a razão, que dependem dessa experiência.

No livro I da Retórica, ao tratar da matéria do gênero judiciário, Aristóteles quer mostrar que temas prazerosos podem ser tratados neste gênero; o prazer consiste na sensação de uma emoção e a fantasia é uma espécie de sensação enfraquecida, a recordação - operada no discurso judiciário - e a expectativa são acompanhadas pela imagem daquilo que se recorda e espera. Há prazer tanto para os que lembram como para aqueles que esperam, pois nisso há sensação, portanto, os prazeres estão presentes na sensação, na memória ou na expectativa.

\section{Os Estóicos}

Os escritos dos antigos estóicos não nos restaram, no entanto, os princípios foram transmitidos mais tarde por outros autores com a compilação de alguns pressupostos teóricos. Essa escola filosófica data do século IV a.C., concentrou-se em Atenas e tem dentre seus principais representantes Zenão de Cício (336-264), Cleanto (331-232) e Crisipo (280-210). Opunha-se à escola epicurista que propunha ao homem submeter-se à sensação, critério da verdade e do bem. De acordo com as citações de Diógenes Laércio, Zenão e Crisipo dividiam a filosofia em lógica, física e moral. Com a 
morte de Zenão, sucedeu-o Cleanto, período em que reinou certa desordem na escola estóica, mais tarde restabelecida pelo seu sucessor, Crisipo ${ }^{40}$.

Interessa-nos no estoicismo antigo a teoria que concerne à fantasia. A questão da lógica, centrada na representação (phantasía), é fundamental na filosofia estóica, ao passo que, para Aristóteles, é simples instrumento (órganon). Vejamos as proposições da teoria estóica que tratam da fantasia compiladas por Diógenes Laércio, Livro VII ${ }^{41}$ :

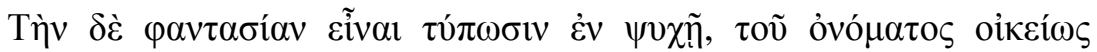

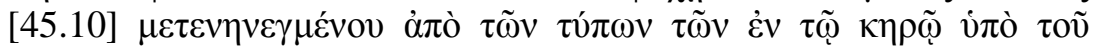

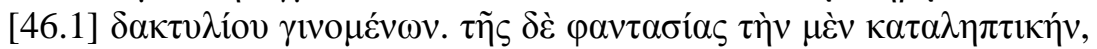

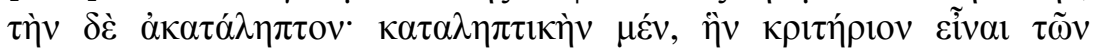

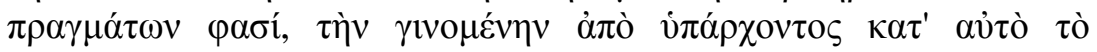

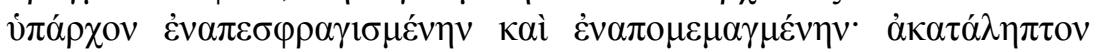

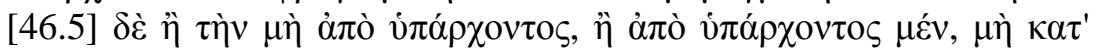

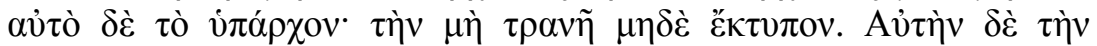

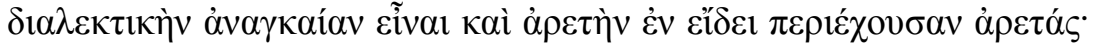

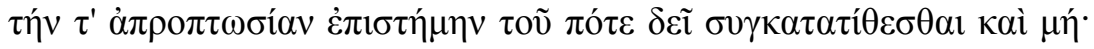

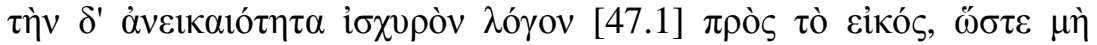

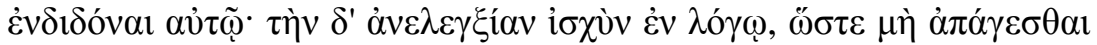

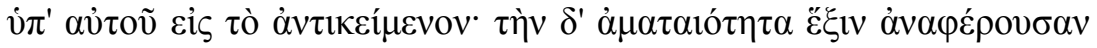

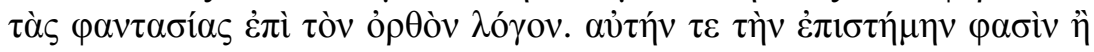

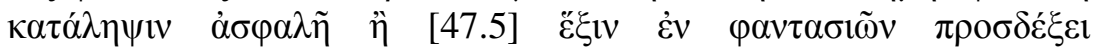

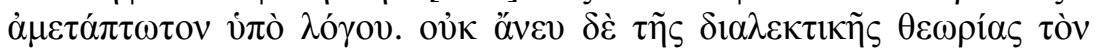

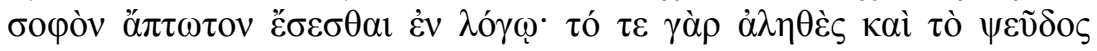

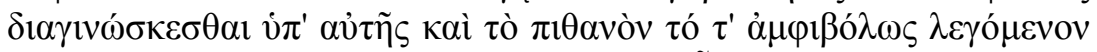

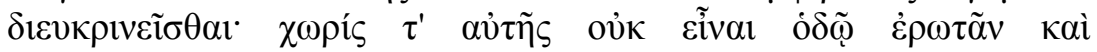

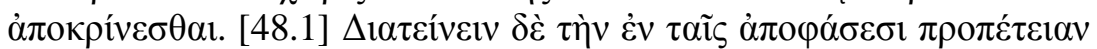

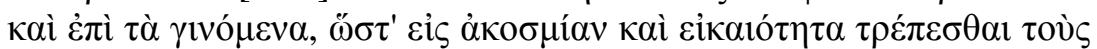

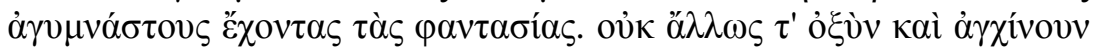

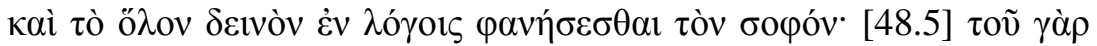

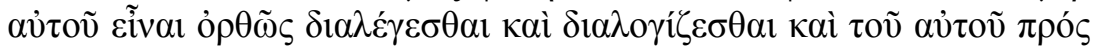

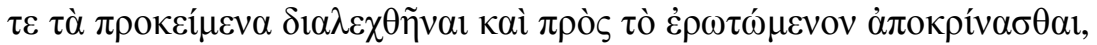

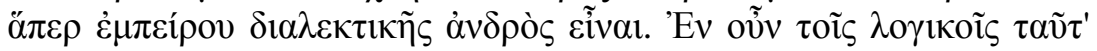

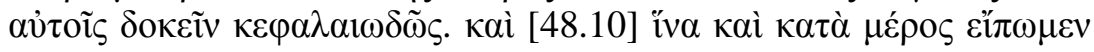

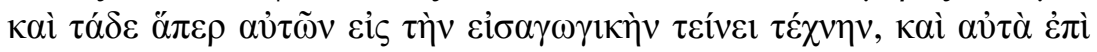

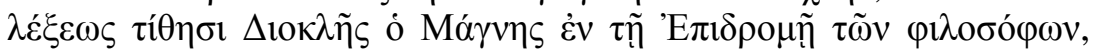

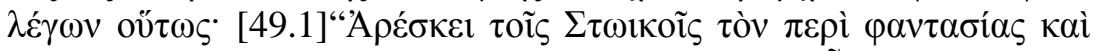

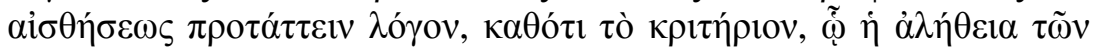

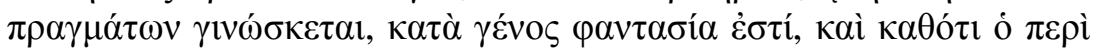

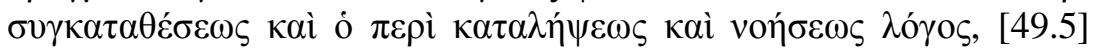

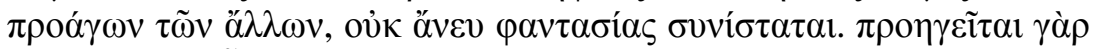

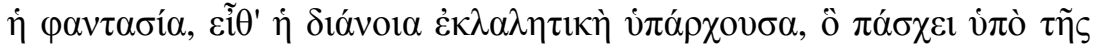

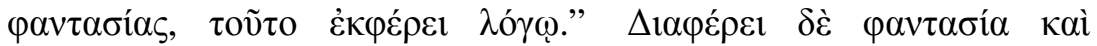

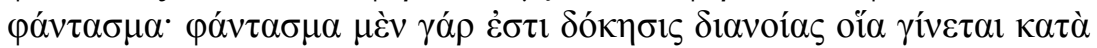

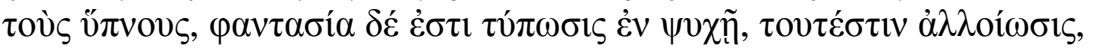

${ }^{40}$ Para uma introdução acerca do estoicismo Cf. BRUN, J. O Estoicismo. Tradução de João Amado. Lisboa: Edições 70. 1986.

${ }^{41}$ Para todas as citações adotamos a edição: LAÉRTIOS, Diógenes. Vidas e Doutrinas dos Filósofos Ilustres. Tradução de Mário da Gama Kury. Brasília: Editora UNB. 1997. 


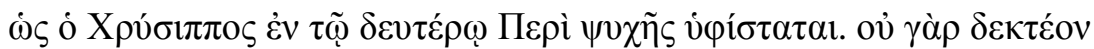

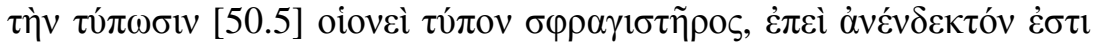

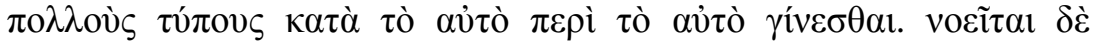

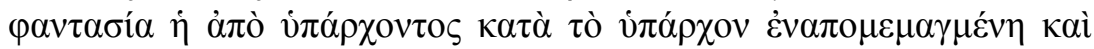

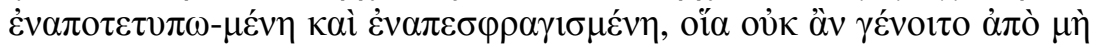

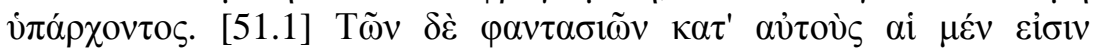

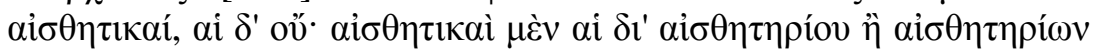

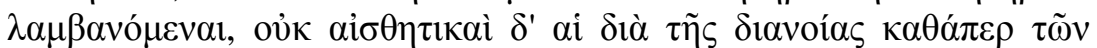

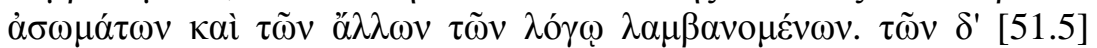

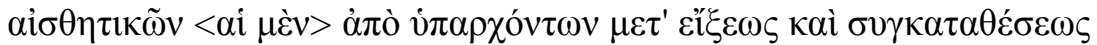

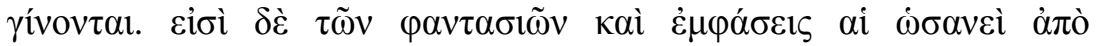

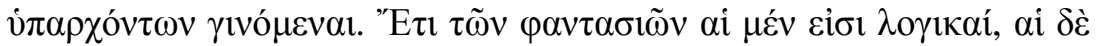

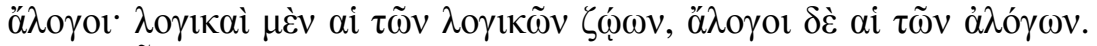

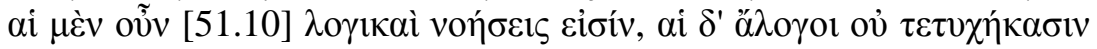

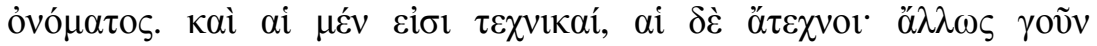
$\theta \varepsilon \omega \rho \varepsilon i ̃ \tau \alpha l$ vं

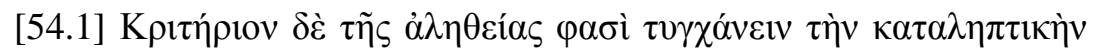

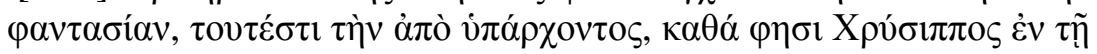

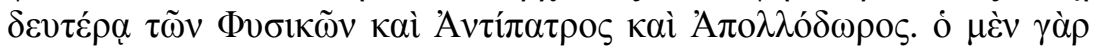

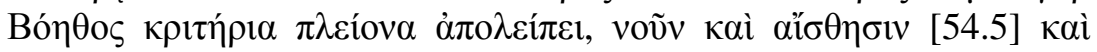

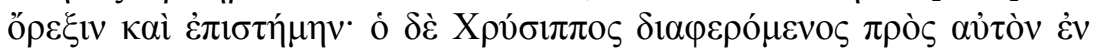

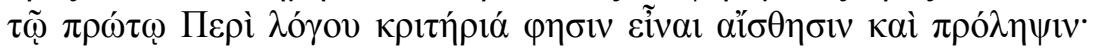

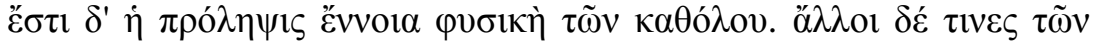

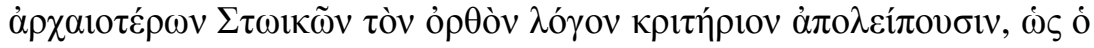

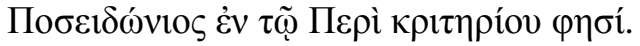

A apresentação ${ }^{42}$ (ou impressão mental [phantasía]) é uma impressão na alma, e tirou-se o seu nome adequadamente da marca feita por um sinete de cera. 46. Há duas espécies de apresentação; uma apreende imediatamente a realidade [phantasía kataleptiké], e a outra apreende a realidade com pouca ou nenhuma nitidez [phantasía akatáleptos]. A primeira, que os estóicos definem como critério da realidade, é determinada pelo existente, de conformidade com o próprio existente, e é impressa e estampada na alma. A outra não é determinada pelo existente, ou se provém do existente, não é determinada de conformidade com o próprio existente, e não é, portanto, nem clara nem distinta. [...] 47. O conhecimento propriamente dito é definido pelos estóicos como uma percepção segura, ou uma faculdade de receber a apresentação, que não pode ser abalada pela razão. [...] 49. [Diócles de Magnésia] "Os estóicos concordam em atribuir a primazia à doutrina da apresentação e da sensação; o critério, com que se discerne a verdade das coisas, é em geral apresentação; a teoria do assentimento, da apreensão e da inteligência, que precede todas as outras, não pode ser expressa firmemente sem a apresentação. A apresentação tem de fato a precedência, a ela segue-se o pensamento que, enquanto é capaz de enunciar o que recebe da apresentação, o exprime por meio da palavra." 50. A apresentação difere da imaginação arbitrária. Esta última é na realidade uma visão falsa da mente como acontece nos sonhos, ao passo que a apresentação é impressão na alma, ou seja, um processo de modificação, como

\footnotetext{
${ }^{42}$ Comumente, os teóricos adotam "representação" para traduzir a phantasía dos estóicos; conservo aqui a nomenclatura adotada pelo tradutor, embora prefira utilizar no decorrer da pesquisa "representação" como correspondente.
} 
admite Crisipos no segundo livro de sua obra Da Alma. Não devemos entender "impressão" no sentido próprio da marca do sinete, porque é inconcebível que muitas marcas possam ocorrer simultaneamente no mesmo lugar. Entende-se por apresentação aquilo que se forma do existente de conformidade com o próprio existente, estampado, marcado e impresso na alma, e que jamais poderia proceder do não existente. 51. Segundo os estóicos, algumas apresentações devem-se a sensações e outras não; as primeiras são determinadas por um ou mais órgãos sensoriais, enquanto temos as segundas por meio do pensamento, como as relativas a objetos incorpóreos e tudo que é percebido pela razão. As apresentações devidas a sensações formamse com base no existente e têm a nossa aprovação e nosso consenso. Há, todavia, apresentações que são aparências que se nos mostram como se proviessem do existente. Outra distinção das apresentações é em racionais e irracionais; são racionais as dos seres racionais, e irracionais as dos seres irracionais; as racionais são um efeito da inteligência, e as irracionais não têm nome. Além disso há apresentações técnicas e não-técnicas (por exemplo, uma estátua é olhada de um modo pelo artista e de outro modo pelo leigo).

54. Os estóicos definem o critério da verdade como a apresentação que apreende imediatamente a realidade, ou seja, que procede do existente, como afirma Crisipos no segundo livro da Física e Antípatros e Apolodoros. Boetos, por seu turno, admite uma pluralidade de critérios - a mente, a sensação, a propensão e a ciência. Por outro lado, Crisipos o contradiz no primeiro livro de sua Lógica, sustentando que os critérios são a sensação e a preconcepção; a preconcepção é a inteligência natural do universo Alguns outros representantes da escola estóica antiga admitem como critério a reta razão, de conformidade com a afirmação de Poseidônios em sua obra Sobre o Critério.

O tratamento dado à fantasia nas teorias platônica e aristotélica gera inúmeros questionamentos, mas é consenso que a percepção é indispensável ao processo; uma das conclusões as quais chegamos é que esse exercício imaginativo pode ser falso, visto que a percepção pode enganar-se acerca dos seus objetos. A princípio diríamos que nisso reside o conflito entre a teoria estóica e a aristotélica: para os estóicos, a representação (fantasia) apreende a realidade; no entanto, a sistematização do conceito por parte de diversos teóricos estóicos nos mostra que eles reconheciam sua complexidade, formulando até mesmo uma tipologia mais delimitada do que a observada em Aristóteles.

Segundo Crisipo ${ }^{43}$, o termo phantasía vem de phôs, "luz", pois assim como a luz que permite a visualização dela mesma e dos objetos que envolve, a representação permite ver ela própria e o objeto que a produziu.

\footnotetext{
${ }^{43}$ Afrimação encontrada em: ILDEFONSE, F. Os estóicos I. Tradução de Mauro Pinheiro. São Paulo: Estação Liberdade. 2007. Pp. 72 - Cf. Aécio IV, 12, 105.
} 
Ainda de acordo com a proposta de Crisipo, a representação verdadeira tem como fundamento um objeto e se imprime na alma; porém, a imaginação arbitrária é uma visão falsa, uma aparição produzida pelo pensamento, como nos sonhos.

Embora haja diferenças pontuais na tradição peripatética e estóica no que concerne à fantasia, a teoria apresentada por Crisipo mantém certa relação com algumas proposições aristotélicas. A representação é um efeito sofrido na alma - páthos, mas não se trata de uma única impressão (týposis), como propusera Zenão, pois a alma pode receber muitas "marcas"; portanto, o que ocorre não é uma inscrição na alma, é antes uma alteração, uma vez que múltiplas marcas não podem coexistir simultaneamente no mesmo lugar ( $\$ 50)$; contudo, a modificação operada na alma possibilita essa pluralidade de impressões, assim, a alma sofreria modificações toda vez que uma nova marca fosse impressa. Nesse ponto, Crisipo explica uma questão que já estava presente em Platão quando ele compara a alma a um bloco de cera ${ }^{44}$ na qual se imprimem as marcas das percepções; contudo, não temos em Platão a proposta de modificação.

Os estóicos apresentam uma vasta tipologia acerca das representações ${ }^{45}$, das quais nos interessa destacar a phantasía katalèptikè, dita "representação compreensiva", já mencionada anteriormente como aquela que apreende a realidade (46), e, consequentemente, é verdadeira. Segundo Zenão, essa representação retranscreve as características do objeto, introduzindo na alma um modelo reduzido da situação, de maneira que o indivíduo que a conheça não deixe de assentir. Por essa razão, os estóicos admitem a phantasía katalèptikè como critério de verdade.

\section{Sexto Empírico}

Assim como Diógenes Laércio, que serviu como base para nossas citações acerca da fantasia, exponho a seguir as proposições de Sexto Empírico concernentes à filosofia estóica que interessam na compreensão da fantasia.

Ao longo de toda sua obra, Sexto discute questionamentos importantes da filosofia; a fantasia frequentemente se insere na busca pelo critério da verdade, predominando constante embate entre várias correntes filosóficas. A fantasia, e também

\footnotetext{
${ }^{44}$ Cf. Teeteto, $191 \mathrm{c}-\mathrm{d}$.

${ }^{45}$ Ildefonse (nota 43) apresenta a tipologia no capítulo 2 destinado à teoria da representação, com base nos escritos de D. Laércio e outros como os de Sexto Empírico, Aécio e Pseudo-Plutarco. Cabe-nos aqui analisar a phantasía katalèptikè, que é, por excelência, considerada verdadeira pelos estóicos e por essa razão serve como base para a teoria da phantasía. Mais adiante retomaremos esse assunto.
} 
a enargia, permeia essa discussão, demonstrando quão importante é a compreensão do conceito.

Sexto Empírico discute o conceito de verdade e afirma em suas Hipotiposes, I, 2-3 que os dogmáticos acreditam ter descoberto a verdade (dentre os quais estão Aristóteles, Epicuro e os estóicos); ao passo que, Clítomaco, Carneades e outros acadêmicos tratam a verdade como algo inapreensível; os céticos ainda estariam investigando essa questão.

Em Contra os Dogmáticos, I, 35-7, o critério lógico dos dogmáticos para descobrir a verdade está dividido em três formas: o agente - pode ser o homem; o instrumento - sentidos; a aplicação - fantasias.

Mais adiante, I, 140, de acordo com Demócrito, três seriam os critérios da verdade: a apreensão das coisas não-evidentes, que são as aparições (phainomena); a investigação, que é a concepção, o assunto da investigação; a escolha e a aversão, que são as afecções.

Já segundo Carneades, que argumentou contra os estóicos e seus predecessores, não há absolutamente nenhum critério de verdade. E, ainda que existisse um critério, não subsistiria separado da afecção produzida pela enargia; pois as criaturas vivas se diferenciam das coisas sem vida por sua faculdade do sentido.

O ceticismo opõe "aparições" (phainomena) a "julgamentos" de quaisquer tipos; tais aparições são os objetos dos sentidos, uma vez que são contrastados com os objetos dos julgamentos [Hipotiposes Pirronianas, I, 8-9].

Embora os céticos não dogmatizem, no sentido de confirmar coisas nãoevidentes, eles reconhecem as sensações que constituem resultados necessários das fantasias. Os céticos não aboliram a aparição, pois não desconsideram as fantasias afetivas que nos induzem ao assentimento de maneira involuntária. O questionamento que se dá é se o objeto essencial é aquilo que aparenta? A discussão não está na aparência, mas na credibilidade que conferimos a ela. Por exemplo, o mel aparenta ser doce para nós, podemos garantir isso porque percebemos pelos sentidos, porém, se é também doce na sua essência é uma questão duvidosa, visto tratar-se de um julgamento em relação ao objeto, não se trata de uma aparição.

De acordo com a escola cética, o phainomen, nome dado à fantasia, constitui o critério da verdade; pois essa reside em sentimento e afecção involuntária. Ninguém discute qual é a aparência do objeto, a dúvida que se coloca é se o objeto é na realidade aquilo que aparenta ser. 
Em razão de tais contradições, os céticos não teriam chegado a uma conclusão em torno de quais fantasias seriam verdadeiras ou falsas.

Dependem da sensação e da fantasia os atos de escolher e evitar, uma vez que são orientados pelo prazer ou pela ausência dele. Os homens são afetados de maneira diferente pelas mesmas coisas, portanto, não se pode julgar os objetos pela sua aparência, pois somos incapazes de explicar o que realmente são.

$\mathrm{O}$ ato de dormir e acordar origina diferentes fantasias, já que não imaginamos quando acordados o mesmo que imaginamos durante o sono e vice-versa. Logo, a existência ou não de nossas fantasias não é absoluta, mas relativa em relação à nossa condição. Nos sonhos, provavelmente, vemos coisas que, quando acordados, seriam irreais, pois existem apenas em nossos sonhos; da mesma maneira que as coisas reais existem quando acordados, ainda que não existam nos sonhos.

As aparições são vistas de determinado lugar, distância ou posição e cada uma dessas condições produz grande divergência no que concerne à fantasia - novamente, é inevitável suspender o julgamento no que diz respeito à veracidade das fantasias.

Nas Hipotiposes Pirronianas, II, 4, temos um postulado que resume o conceito de fantasia para os estóicos: "apreender" significa assentir a respeito de uma fantasia do tipo compreensiva, essa, por sua vez, é derivada de um objeto real, como uma estampa ou impressão sobre a mente, correspondendo ao objeto verdadeiro, pois tal imagem não poderia resultar de algo irreal.

Alguns teóricos, tais como Heráclito, Parmênides e Demócrito, afirmam que os sentidos têm impressões vazias - nenhum objeto apreendido tem alguma existência real. Outros, tais como Epicuro e Protágoras, afirmam que todos os objetos realmente existem. Os peripatéticos, os estóicos e os acadêmicos, afirmam que alguns dos objetos são reais, outros irreais. Portanto, não deveríamos resolver a controvérsia pelos sentidos. Coloca-se então a questão: os sentidos têm afecções ilusórias ou apreendem algum objeto real? O que se pode afirmar é que os sentidos são apreensivos: eles são afetados de maneiras diversas pelos objetos externos - o paladar, por exemplo, pode perceber o mesmo mel como doce ou amargo, conforme já mencionado.

Não é possível afirmar que todas as fantasias são verdadeiras ou falsas, ou em parte verdadeiras, em parte falsas, já que não há acordo quanto a um critério. Contudo, as fantasias em estado natural são confiáveis, já aquelas produzidas nos homens que não estejam em condição natural não o são. 
O julgamento dos objetos reais apenas por meio dos sentidos é impossível. A visão, mesmo quando está no estado natural, pode afirmar que uma torre é redonda, outra vez, a mesma torre pode ser considerada quadrada. Isso ocorre porque os sentidos se contradizem, por essa razão, apenas o sentido não serve como critério para julgar os objetos externos reais.

Os estóicos declaram que a fantasia se trata de uma impressão na alma que, por sua vez, não será capaz de conservar a recordação de todos os conceitos que compõem uma arte, uma vez que os conceitos preexistentes são obliterados pelas subsequentes alterações. A fantasia é, portanto, inconcebível e mesmo que não o fosse, ainda não seria apreensível, uma vez que se trata de uma afecção.

Mesmo se afirmarmos que a fantasia é algo apreensível, os objetos não podem ser julgados de acordo com ela; visto que o intelecto, como afirmam os estóicos, não faz contato com objetos externos e não recebe as fantasias por meios próprios, mas por meio dos sentidos. Os sentidos não apreendem objetos reais externos, mas apenas suas próprias afecções. Logo, a fantasia será a afecção do sentido; distingue-se, portanto, da realidade externa. Se essa afecção difere do objeto real externo, a fantasia não será aquela da realidade externa, mas de algo mais que é diferente. No entanto, se o intelecto julgar de acordo com isso, fará um mau julgamento e em desacordo com a realidade.

Portanto, é impossível afirmar que a alma apreende a realidade externa por meio das afecções dos sentidos, devido à similaridade dessas afecções aos objetos reais externos. Aqui Sexto questiona: como o intelecto saberia se as afecções dos sentidos são similares aos objetos dos sentidos, quando ele mesmo não encontrou os objetos externos e os sentidos não o informam a respeito da natureza real deles, mas apenas de suas próprias afecções?

As aparições (phainomena) constituem um instrumento de distorção da verdade produzido pelos falsos argumentos sofísticos.

Em Contra os Dogmáticos, I, 53-4, Xeníades de Corinto teria afirmado que todas as coisas são falsas e, portanto, toda fantasia e opinião também o são. Tal fato pode ser provado pela depreciação dos sentidos, comprovadamente falsos; se o critério supremo de todas as coisas é falso, tudo necessariamente também será - como os sentidos são o critério supremo de todas as coisas, logo, todas as coisas são também.

No mesmo tratado, Sexto prossegue a respeito do assunto. Protágoras de Abdera teria abolido o critério da verdade: ele afirma que todas as fantasias e opiniões são 
verdadeiras e que a verdade é relativa, pois algo que parece para um indivíduo de tal forma e esteja de acordo com sua opinião será real em relação a essa pessoa.

Os platonistas afirmam que a razão dita "compreensiva" engloba a enargia e a verdade, pois, ao julgar a verdade, a razão deve começar a partir da enargia, então o julgamento das coisas verdadeiras é efetivado por meio das coisas evidentes. Contudo, a enargia não é autossuficiente para o conhecimento da verdade, é necessário estar presente um instrumento que julgue o que simplesmente aparenta existir e o que subsista na verdade, ou seja, a razão. A razão precisa da emoção, pois é por meio dela que recebe a fantasia e produz o pensamento e o conhecimento do que é a verdade.

Para os estóicos há três critérios da verdade: o conhecimento, a opinião e, entre os dois, a apreensão. O conhecimento é a correta e firme apreensão que não pode ser alterada pela razão. A opinião é fraca e sua confirmação falsa. A apreensão constitui uma confirmação para uma fantasia compreensiva, que não pode ser falsa.

A fantasia apreensiva, de acordo com os estóicos, é algo verdadeiro e incapaz de ser falso. O conhecimento subsiste apenas no sábio, a opinião, nos tolos, mas a apreensão é compartilhada por ambos e é um critério da verdade. Arcesilau contestou ao provar que a apreensão não é um critério intermediário entre o conhecimento e a opinião: se ocorrer no sábio, é conhecimento, mas no tolo, é opinião.

Quando o sentido é afetado de alguma maneira devido ao impacto das coisas evidentes, então os objetos são mostrados. Portanto, o critério deve ser procurado na afecção da alma causada pela enargia. Tal afecção deve ser um indicativo dela mesma e da aparição que a causou - essa afecção nada mais é do que a fantasia.

Como já observamos em Crisipo, Sexto também nos traz a afirmação de que a fantasia é como a luz: a luz mostra a si mesma e todas as coisas que envolve; a fantasia - que é o fator primário da cognição da criatura viva - deve, como a luz, revelar-se e indicar o objeto evidente que a produziu. Contudo, ela nem sempre indica o objeto verdadeiro, frequentemente se engana; é, portanto, má mensageira ao relatar impropriamente o objeto de origem, por essa razão, a fantasia não poderia ser um critério da verdade, mas se assim a considerássemos, apenas aquela que fosse verdadeira o seria.

Não há fantasia verdadeira que não possa ser falsa, porém, uma fantasia falsa existe exatamente para lembrar toda fantasia aparentemente verdadeira; logo, o critério consistiria de uma fantasia que contém o verdadeiro e o falso do mesmo modo. No 
entanto, a fantasia que comporte a verdade e a falsidade não pode ser apreensiva e não será um critério da verdade.

A fantasia terá dois aspectos de acordo com sua natureza: um na sua relação com o objeto apresentado (phantaston) e outro na sua relação com o sujeito que sofre a fantasia. No que concerne ao objeto apresentado, pode ser verdadeiro (quando está de acordo com o objeto apresentado) ou falso (quando não está de acordo com o objeto). No que se refere ao sujeito, um tipo de fantasia será aparentemente verdadeira, a outra, aparentemente falsa. As aparições verdadeiras são nomeadas pelos acadêmicos de emphasis, fantasia provável. Ao passo que, as aparentemente falsas denominam-se apemphasis, fantasia improvável. A partir de tais fantasias, aquilo que é evidentemente falso ou aparentemente não é verdadeiro não pode ser um critério, mesmo que seja derivado de um objeto existente, pois não está de acordo com ele. Assim foi a fantasia de Electra que Orestes presenciou quando ele supôs que ela fosse uma das Fúrias (Eur. Orest. 264).

A partir do tipo aparentemente verdadeiro de aparição, um é obscuro, como, por exemplo, no caso daqueles que têm uma percepção que está confusa por causa da pequenez do objeto visto, da distância ou mesmo da fraqueza do sentido da visão.

A fantasia que for obscura não será um critério, pois não indica claramente ela mesma ou o que a causou, não nos persuade a confirmá-la. Mas o que aparenta ser vividamente verdadeiro é o critério da verdade de acordo com a escola de Carneades, apresentando, dessa maneira, grande variedade e tendo em vista que uma fantasia se revela como mais provável e mais vívida do que outra.

A probabilidade é usada em três sentidos: é verdadeira e assim aparenta ser; é falsa e aparenta ser verdadeira; é, ao mesmo tempo, verdadeira e falsa. Portanto, o critério será a fantasia aparentemente verdadeira - a que os acadêmicos chamam "provável”. Às vezes, porém, a impressão a torna falsa, então somos compelidos a fazer uso da fantasia que é, ao mesmo tempo, verdadeira e falsa. Mas a rara ocorrência deste tipo (o que imita a verdade) não deveria nos fazer desconfiar do tipo que, como uma regra geral, reporta verdadeiramente; pois o fato é que tanto nossos julgamentos, como nossas ações, são reguladas pela regra geral; segundo Carneades, este é o primeiro critério geral.

Sabe-se que nenhuma fantasia é simples na forma: como vínculos numa corrente, uma segura a outra - trata-se de um segundo critério, a fantasia que é, ao mesmo tempo, provável e "irreversível". Por exemplo, quando se recebe a fantasia de 
um homem, necessariamente recebe-se a fantasia de suas qualidades pessoais e condições externas. Então, se nenhuma dessas fantasias perturbarem nossa crença aparentando falsidade e tudo parecer verdadeiro, nossa convicção será maior.

Afirmamos que algo é verdadeiro quando estamos bem acordados ao vê-lo e existe, ao mesmo tempo, uma atmosfera clara e uma distância moderada, além do objeto estar imóvel. Em tais condições a fantasia é confiável, uma vez que temos tempo suficiente para examinar os fatos observados no lugar da fantasia. O mesmo ocorre com a fantasia irreversível, pois ela é aceita sempre que não há algo capaz de contradizê-la.

Epicuro afirma que a fantasia e a opinião são correlativas: ele denomina a fantasia como sempre verdadeira. Assim como as afecções primárias (prazer e dor) surgem devido a certos agentes (prazer, de coisas prazerosas; dor, de coisas dolorosas), no caso das fantasias, que são nossas afecções, o agente que produz cada uma delas é sempre apresentado inteiramente e, ao ser apresentado, é incapaz de ser produtor da fantasia sem ser na verdade como aparenta.

O objeto visível não apenas parece, mas é de fato visível; portanto, tais fantasias são verdadeiras. Para os epicuristas, se a fantasia for denominada "verdadeira" sempre que surgir de um objeto real e estiver de acordo com ele, logo, toda fantasia será verdadeira, pois todas surgem de um objeto real apresentado (phantaston) e está de acordo com ele.

A visão percebe uma torre à longa distância como se fosse pequena e redonda, mas de perto é grande e quadrada. Pode-se dizer que o sentido reporta o que vê de maneira verdadeira, porque se o objeto aparenta essa forma, ele realmente é assim, uma vez que os limites da imagem são apagados por meio de sua passagem no ar. E quando novamente aparentar ser grande, corresponderá a essa última forma, uma vez que não é mais o mesmo objeto; no entanto, o objeto corresponderá às duas fantasias.

A função especial do sentido é perceber apenas o que o afeta com sua presença, mas não discernir se aqui o objeto é uma coisa, ali, outra. Sabemos que, pelas razões anteriormente apresentadas na doutrina de Epicuro, as fantasias são todas verdadeiras; as opiniões, contudo, não são sempre verdadeiras, mas possuem distinções - algumas delas são verdadeiras, outras falsas. Tratando-se de julgamentos que concernem às nossas fantasias, julgamos algumas vezes corretamente e, outras, erroneamente, quer seja acrescentando ou subtraindo algo das fantasias.

As opiniões verdadeiras seriam então aquelas que testemunham a favor e não contra a enargia do sentido; e falsas aquelas que testemunham contra. $\mathrm{O}$ testemunho 
confirmatório é a apreensão por meio da enargia, por exemplo, com a aproximação de Platão que está à distância, adivinhamos que é ele por causa da distância; quando, porém, ele se aproxima, testemunhamos o fato de que ele é Platão, pois a distância diminui - confirma-se, portanto, pela verdadeira enargia do sentido. A base e a fundação de tudo é essa enargia do sentido.

O sentido é afetado por objetos sensíveis, como resultado dessa afecção dos sentidos nas criaturas que são superiores temos a memória e a fantasia: a memória da afecção percebida pelo sentido e a fantasia do objeto sensível que produziu a afecção no sentido.

Esta afecção que é denominada tanto "memória" e "fantasia" possui uma terceira e surpreendente afecção separada - o pensamento. É um tipo de fantasia racional (logikês), que é um resultado posterior, consequência do nosso julgamento. Por exemplo, quando alguém, recebendo a enargia de algo, sofre certa afecção do sentido e certa perturbação, produz-se uma fantasia na alma (semelhante a uma pegada) e a partir dessa fantasia há um objeto imaginado (phántasma), voluntariamente desenhado e representado por ele.

Quando a alma se rende à fantasia produzida nela por meio do sentido e confirma o objeto que apareceu, a isto chamamos "opinião". O pensamento é naturalmente incapaz de julgar os objetos se estiver separado do sentido.

Já vimos que a fantasia para os estóicos é uma impressão na alma. Mas entre eles houve desacordos: Cleantes entendeu "impressão" como aquela feita na cera pelo anel-sinete, mas Crisipo considerou isso um absurdo. Para Crisipo, quando a mente imagina um objeto triangular e quadrangular, o corpo precisa ser circunscrito por diferentes formas ao mesmo tempo e tornar-se simultaneamente triangular $\mathrm{e}$ quadrangular. Além disso, se muitas fantasias ocorressem em nós simultaneamente, a alma receberia incontáveis formações cujo resultado é pior do que o anterior.

O próprio Crisipo, no entanto, suspeitou que o termo "impressão" era usado por Zenão no sentido de "alteração", daí a definição de fantasia ser "uma alteração na alma”. Isto já é admissível, uma vez que, quando várias fantasias coexistem em nós, o mesmo corpo deveria admitir inumeráveis alterações. Assim ocorre com o ar, por exemplo, quando muitas pessoas estão falando simultaneamente, ele recebe, num único momento, incontáveis e diferentes impactos e sofre diversas alterações também.

Outros teóricos afirmam que nem mesmo a definição com a emenda de Crisipo está correta. Pois, se a fantasia existe, é uma impressão e alteração da alma; mas se uma 
impressão da alma existe, não é sempre uma fantasia. Por exemplo, quando arranhamos a mão, é produzida uma impressão e também uma alteração, mas não uma fantasia. Como objeção, os estóicos declaram que na frase "impressão da alma" estão implícitas também as palavras "enquanto seja alma", então a sentença completa é "a fantasia é uma impressão na alma enquanto seja a alma”. Quando afirmamos isso, implica-se que a fantasia ocorra em certa parte da alma, a saber, a parte regente (hegemonikoi), portanto a definição é: "a fantasia é uma alteração na parte regente (da alma)".

O impulso, a comprovação e a apreensão são alterações da parte regente, mas são diferentes da fantasia, pois esta última é um processo passivo, as demais estão mais para atividades. Logo, a definição anterior é inadequada - afirmar que a fantasia seja uma alteração da parte regente é uma falta, uma vez que isto não está mais relacionado à fantasia do que qualquer um dos movimentos enumerados. Em relação a esta última objeção, os estóicos novamente afirmam que devemos subentender na definição "por meio da passividade".

Ainda assim, esta alteração (da parte regente), embora ocorra por meio da passividade, não é fantasia; a não ser que digam mais uma vez que a fantasia é uma forma especial distinta das condições passivas, ou ainda que seja de coisas externas ou de nossas próprias afecções internas (mais precisamente chamada "atração vazia"); está sempre implicado na definição da fantasia que a passividade diz respeito ao impacto externo ou às afecções internas. Mas esta implicação adicional não é possível no caso da alteração por causa do processo de crescimento (auxésis) ou criação. Portanto, na doutrina estóica é extremamente difícil definir a fantasia - mesmo porque, há várias distinções no que se refere à fantasia.

As fantasias são prováveis quando produzem um suave movimento na alma, como as que ocorrem no momento presente e têm certo grau de obviedade, por exemplo, "é dia" quando for dia. As fantasias improváveis não são óbvias e nos fazem recusá-las, por exemplo, "é dia, o sol não está sobre a terra". E são, ao mesmo tempo, "prováveis" e "improváveis" as fantasias de afirmações problemáticas, ora é um tipo, ora outro. Não são "nem prováveis ou improváveis" aquelas que se preocupam com julgamentos desse tipo: "as estrelas são em número par, em número ímpar".

Algumas das fantasias prováveis são verdadeiras, outras falsas, ou mesmo ambas ou nenhuma das duas.

As fantasias verdadeiras podem ser de dois tipos: não-apreensíveis e apreensíveis. As não-apreensíveis são experimentadas pela pessoa em condição 
mórbida: o indivíduo as recebe e, embora sejam verdadeiras, não são apreendidas, pois ocorre exteriormente e fortuitamente, portanto, com frequência não são confirmadas. As apreensíveis são causadas por objetos existentes imaginados e estampados na pessoa de acordo com o objeto, de tal maneira que não poderiam ser derivadas de algo inexistente; pois, como os estóicos consideram que essa fantasia é eminentemente perceptiva de objetos reais e reproduz com precisão artística todas as suas características, afirmam que a fantasia possui cada uma delas como seu atributo.

A fantasia deve ser estampada na pessoa para apresentar todas as características dos objetos apresentados com exatidão artística. Assim como os escultores colocam suas mãos em todas as partes dos trabalhos que estão completando, como os selos dos anéis que sempre imprimem todas as suas marcas na cera, da mesma forma aqueles que experimentam a apreensão dos objetos reais, devem perceber todas as suas características.

Considerando que os antigos estóicos declaram que a fantasia apreensiva é o critério da verdade, os estóicos posteriores acrescentaram a afirmação "contanto que não haja obstáculo". Às vezes, quando uma fantasia apreensiva ocorre pode ainda ser improvável por causa das circunstâncias, por exemplo: Héracles se apresentou para Admeto trazendo Alceste de volta da sepultura, Admeto recebeu de Alceste uma fantasia apreensiva, mas não acreditou nela. Portanto, a fantasia apreensiva não é critério incondicional da verdade.

Segundo Sexto, alguns filosófos fazem da fantasia a regra de coisas relacionadas à fantasia "apreensiva" (os estóicos), outros à fantasia "provável" (os acadêmicos).

Se a alma, quando afetada fantasticamente, é marcada como a impressão da cera, a última marca sempre manterá ofuscada a fantasia anterior, assim como a impressão do segundo selo oblitera a do primeiro. Mas se é assim, a memória é abolida, constituindo "um tesouro das fantasias", e toda arte é abolida; pois a arte é um "sistema e agregação de apreensões", mas não é possível para muitas e diferentes fantasias subsistirem na parte regente, quando suas impressões mentais variam de tempo em tempo. Então, a primeira impressão na mente não é uma fantasia.

Se a fantasia for uma mudança e uma alteração da alma, ela não existe, visto que, ainda que concedamos a alteração, a existência real da fantasia não será imediatamente admitida. Pois já dissemos tratar-se de uma impressão da parte regente, mas não há discussão acerca da existência da parte regente ou em que local exista. Alguns teóricos, como Asclepíades, dizem que não existe parte regente, outros 
acreditam que existe, embora não entrem em acordo a respeito do lugar em que se encontra.

Além disso, a fantasia é um efeito do objeto apresentado (phantaston); o objeto, por sua vez, é a causa das fantasias e é capaz de impressionar a faculdade sensitiva. Uma vez que a mente apreende as fantasias, ela receberá os efeitos dos objetos apresentados, mas não os próprios objetos externos. Portanto, o pensamento conhecerá as coisas similares aos objetos apresentados, mas não os objetos.

No entanto, considerando que o objeto apresentado seja a causa e, a fantasia, o efeito, o mesmo objeto será outro que não ele mesmo - causa e efeito simultaneamente - conclusão ilógica.

Mesmo admitindo a fantasia daquela natureza que os dogmáticos desejam, se a fantasia é aceita como critério, nós teremos que afirmar ou que todas são verdadeiras (Protágoras) ou falsas (Xeníades), ou que algumas são verdadeiras e algumas falsas (os estóicos, os acadêmicos e os peripatéticos). Porém, não devemos afirmar que todas são verdadeiras ou falsas, ou algumas verdadeiras e outras falsas; Portanto, não se pode dizer que a fantasia seja o critério. Ninguém pode dizer que toda fantasia seja verdadeira porque isso refuta a si mesmo, visto que muitas são falsas.

Portanto, podemos afirmar que algumas fantasias são confiáveis e outras não: os estóicos aprovam as fantasias apreensivas, os acadêmicos, aquelas que aparentam ser prováveis; no entanto, tais assertivas não parecem ser verdadeiras. Uma fantasia apreensiva é "impressa por um objeto real e de acordo com esse objeto, logo, não poderia ser produzida por algo irreal". Mas Carneades afirma que as fantasias também podem ser produzidas por objetos irreais; além disso, nos sonhos e na loucura, as aparições nos afetam com a mesma sensação correspondente. Assentimos tanto as fantasias apreensivas como as não-apreensivas.

A visão não apreende o objeto de fato, mas apenas sua aparência. Portanto, se a fantasia apreensiva coincide com a não-apreensiva, ela não poderá ser critério da verdade.

Há coisas que embora não sejam apreensíveis, podem ser verdadeiras: é o caso dos números, a partir dos quais é possível depreender conceitos não-apreensíveis, por exemplo, quando se diz "50 é pouco", podemos depreender "51 é pouco".

Para uma fantasia perceptiva deve haver cinco componentes: o órgão do sentido, o objeto do sentido, o lugar, o modo e o intelecto. Na ausência de um único destes, a percepção, segundo os estóicos, não será seguramente efetiva. Portanto, alguns dizem 
que a fantasia apreensiva não é um critério universal, mas apenas quando não há um obstáculo presente. Isto, contudo, é impossível, por causa das diferenças nas passagens sensoriais e por causa das circunstâncias externas e de muitas outras condições, as coisas não aparecem para nós da mesma forma. Com efeito, pode-se dizer que uma coisa que aparece por meio de um sentido em particular e numa circunstância em particular, não é possível ter certeza se sua aparência é verdadeira ou se aparenta uma forma diferente. Portanto, dadas essas considerações, nenhuma fantasia existiria sem obstáculo.

Para Sexto, os estóicos cometem um equívoco ao afirmar que a fantasia é impressa por um objeto real, mas não definem ao certo o que seja esse objeto real.

A fantasia não-apreensiva é o critério de tudo, no sentido de que sua função é examinar também o que seja apreensivo. Se adotarmos a fantasia apreensiva como critério para distinguir as fantasias apreensivas e não-apreensivas, seria necessário também o fato de que a fantasia que as julga deva ser testada por uma apreensiva e assim permaneceria ad infinitum. A fantasia provável não pode ser o critério da verdade, pois o exame atento do objeto poderia revelar não tratar-se de algo verdadeiro. Por fim, a fantasia não pode ser o critério da verdade porque nada garante um conhecimento que seja seguro.

A experiência da fantasia é parte involuntária e parte voluntária e dependente do nosso julgamento. Essa experiência é involuntária e não depende da pessoa, mas da causa da fantasia, quando o indivíduo é afetado de modo particular (por exemplo, a sensação de brancura, ao se apresentar a cor branca). Mas o ato de assentir tal afecção reside no poder da pessoa que recebe a fantasia. A apreensão tem como antecedente a fantasia apreensiva que é o assentimento; a fantasia apreensiva, por sua vez, tem como antecedente a própria fantasia, da qual é espécie. Mas se a fantasia não existir, tampouco a apreensão existirá.

Epicuro acha que os homens derivaram a concepção acerca de Deus a partir das fantasias recebidas no sono, pois "quando grandes imagens da forma humana os impressionavam durante o sono, supunham que deuses de forma realmente humana existissem" [Contra os Físicos, I, 25].

Retomando as Hipotiposes Pirronianas, Sexto afirma em I, 170 que alguns teóricos, tais como Protágoras e Epicuro, acreditam que os objetos sensíveis são verdadeiros; para outros, dentre os quais se destacam Platão e Demócrito, apenas os inteligíveis o são. Há ainda aqueles que acreditam que alguns sensíveis e alguns 
inteligíveis são verdadeiros, trata-se dos peripatéticos e dos estóicos. Esta é mais uma das questões em que não é possível chegar a um consenso.

No livro II das Hipotiposes, 63/69, sabemos que não se deve julgar os objetos apenas pelo intelecto, mas também por meio dos sentidos. No entanto, isso parece impossível, pois os sentidos não guiam o intelecto para a apreensão, até mesmo se opõem a isso, visto que o mel parece amargo para alguns e doce para outros - isto é aplicável a todos os sentidos e objetos sensíveis. Quando o intelecto parte dos sentidos, ele é compelido a fazer declarações diversas e conflituosas, aspecto que é alheio ao critério da apreensão. Ao persistir nessa questão, Sexto conclui que o critério "por meio do que", ou seja, o instrumento, não pode existir.

Alguns filósofos definem o conceito de homem genérico pela lógica, imaginando que, a partir disso, a concepção do homem particular também emergirá. A concepção geral é de que o homem é um animal racional e mortal, receptivo do pensamento e da inteligência. $O$ que nos é apresentado não é o homem, mas as propriedades deste. A propriedade de algo, porém, é diferente do objeto ao qual pertence, visto que se não fosse diferente não seria uma propriedade, mas o próprio objeto - Contra os Dogmáticos, I, 269-70.

Se o sentido da visão não é perceptivo das propriedades do corpo, muito menos será capaz de discernir o corpo. Nem, de fato, é uma tarefa para a audição, o olfato, o paladar ou o tato; pois cada um destes sentidos é apenas conhecedor da percepção própria dele mesmo, que não será a substância corporal. Portanto, os sentidos não apreendem a substância corporal. Aqui observamos concordância com as características próprias de cada objeto, percebidas apenas por um sentido, proposta na tipologia de Aristóteles.

Constantemente, Sexto reitera a tese de que a fantasia é distinta do objeto que representa, para reforçar a argumentação de que ela não pode ser o critério de verdade que os filósofos buscam. Mesmo que o intelecto receba a afecção dos sentidos, ele não conhecerá os objetos externos, uma vez que estes são distintos das nossas afecções e a fantasia é diferente do objeto apresentado (phantaston).

A alteração imaginativa (phantastikós) permite que o sentido e o pensamento estejam conscientes das coisas.

Sexto Empírico corrobora as aparições como forma de impressão, porém, não se trata precisamente de uma impressão, mas alteração do intelecto. Entretanto, para ele, essa definição é ainda mais inadequada: um dos tipos de alteração ocorre por meio da 
afecção, o outro consiste em mudança na substância. Dá-se por meio da afecção quando, por exemplo, a estátua permanece a mesma quando aquecida em um momento pela luz do sol sobre ela e, em outro, resfriada pelo orvalho que cai sobre ela à noite. Mas só consistiria em mudança de substância, por exemplo, se a estátua derretesse e se tornasse uma esfera de bronze.

Se a fantasia é então uma alteração da alma por meio da afecção, visto que a afecção seja diferente de acordo com as fantasias que são diferentes, as novas afecções mudam a mais antiga, então não haverá retenção de qualquer coisa no intelecto, o que também é considerado um absurdo. Enquanto isso consista em mudança de substância, no momento de receber uma fantasia, a alma através da alteração deixará de ser alma e será destruída. Portanto, a fantasia é uma alteração da alma, mas não por meio da mudança.

No livro II do Contra os Dogmáticos, § 63, Sexto cita Epicuro ao afirmar que todos os sensíveis são verdadeiros e toda a fantasia parte de um objeto real e, consequentemente, do mesmo tipo de objeto que provoca a sensação; aqueles que dizem que algumas fantasias são verdadeiras, outras falsas, são conduzidos erroneamente em razão de sua inaptidão em separar a opinião da clara evidência (enargeia). Portanto, no caso de Orestes, quando ele fantasiou ter visto as Fúrias (Eur. Orest. 255), seu sentido, provocado pelas imagens, foi verdadeiro (pois as imagens realmente existiram), mas sua mente, ao pensar que as Fúrias fossem sólidas, formou uma falsa opinião.

A afirmação de que algumas fantasias advêm de corpos sólidos e outras de imagens, tendo em vista que a enargia é uma coisa e a opinião outra, postula um questionamento: como se distinguem as fantasias que surgem de um corpo sólido e de uma imagem?

A teoria estóica apresenta dificuldades para solucionar tal discussão. Segundo o estoicismo, algumas fantasias são "vazias" (como a de Orestes) e outras são "distorcidas" (derivadas de objetos reais, mas não em conformidade com eles, como a de Héracles em sua loucura). No entanto, os estóicos não são capazes de dizer quais são verdadeiramente apreensíveis e derivadas de objetos reais e em conformidade com os próprios objetos.

Segundo os céticos, algumas coisas têm existência relativa, outras, absoluta. As de existência absoluta são aquelas percebidas com uma subsistência própria e de maneira absoluta (como o branco, o amargo etc.) - são apreendidas sem o acompanhamento de qualquer outra sensação. As coisas de existência relativa são 
percebidas numa relação estabelecida com outra coisa e não apreendida absolutamente, como, por exemplo, mais branco e mais doce. Dentre os objetos apreendidos pelo homem, portanto, alguns parecem ser apreendidos pelos sentidos, outros, pelo intelecto.

Demócrito afirma que nenhum dos sensíveis realmente existe: nossas percepções dos objetos são certas afecções vazias dos sentidos, logo, não há nada doce ou amargo, quente ou frio, pois estes são os nomes de nossas afecções. Mas Epicuro declarou que todos os sensíveis realmente existem assim como aparentam e se apresentam na percepção; o sentido, por sua vez, nunca mente, embora pensemos o contrário. Os estóicos e os peripatéticos, procurando um meio-termo, declararam que alguns sensíveis realmente existem, quando verdadeiros, ao passo que, alguns não existem, quando a percepção se engana a respeito deles.

A diferença do homem em relação aos animais irracionais não reside na razão discursiva, mas no que diz respeito à razão interna. Também não diferem quanto à fantasia - pois os animais também as recebem -, mas com respeito à fantasia transitiva e construtiva, ou seja, o processo que permite a fundamentação das representações do intelecto.

Acredita-se que haja coisas evidentes e outras não-evidentes. As evidentes são aquelas percebidas involuntariamente por meio da fantasia e da afecção como as que ocorrem no momento: "é dia".

A enargia (enárgeia) é a aparência das partes de um todo - Contra os Físicos, I, 339. No geral, tudo é concebido ou por meio da enargia das coisas expostas aos sentidos (como o branco e o preto, o doce e o amargo) ou por meio da transição de tais coisas. A transição pode ocorrer de várias maneiras: semelhança, composição, analogia, adição ou subtração.

No mesmo tratado, II, 49, discute-se acerca do movimento, a enargia constitui aqui um critério importante, se considerado como evidência do sentido. O movimento é algo existente se o julgamos pelas aparições (phainomena), mas julgando-o pela razão filosófica ele não existe. A enargia dos sentidos defende a existência do movimento (kinésis), considerando-se que alguns afirmam que o movimento é percebido pelos sentidos, ao passo que outros declaram que é pecebido pelo intelecto por meio da sensação. O movimento seria um objeto do sentido pelo fato de que a mesma afecção não é produzida no sentido (na visão, por exemplo) por um objeto quando ele move e um quando ele estaciona, mas o objeto sem movimento produz um tipo de afecção e um objeto que se movimenta um tipo distinto. 
Mas aqueles que persistem que o movimento não é percebido pelos sentidos, mas pelo intelecto por meio da percepção, afirmam que todo movimento vem por meio da recordação coexistente. A partir da recordação do que este corpo específico era anteriormente, naquele lugar específico, adquirimos então a concepção do movimento e do objeto movido. Como a recordação não é o trabalho de um sentido irracional, mas da faculdade da razão, conclui-se que o movimento não é percebido pelo sentido, mas pelo intelecto. Todo movimento é concebido envolvendo a partida de um lugar e a ocupação de outro; os sentidos, porém, não podem perceber nem o lugar (pois não é sensível), nem a ocupação e a partida (pois tais coisas são observadas por meio da memória, mas o sentido irracional existe sem a memória).

Algumas pessoas são mais perspicazes no sentido da visão do que outros, conforme observado em Aduersus Mathematicos, V, 81 - um objeto que não é visto por nós em razão da distância, é percebido como algo muito grande pelas águias e falcões devido à agudeza de sua visão.

Por fim, alguns filósofos discutem até mesmo a existência da alma; se ela não existe tampouco os sentidos podem existir, pois são partes da alma. E se os sentidos não existem, também não existem os objetos dos sentidos, pois sua existência é concebida com relação aos sentidos.

\section{Cícero}

No livro II do De Oratore, nos \$357-59, Cícero emprega uma metáfora que compara imagem e discurso, destacando-se entre todas as comparações feitas no tratado nesse âmbito. Embora não use o termo, o efeito que se pode obter com o sentido da visão lembra o conceito da fantasia, cujo correspondente latino é a uisio ${ }^{46}$. A fantasia assemelha-se muito à enargia, contudo, atentando para sua definição, podemos supor que se trata do resultado obtido com o emprego dessa figura ou ainda a enargia poderia ser o resultado da fantasia, considerando que ela se trata de um exercício capaz de tornar o discurso visível, nítido, característica da enargia. Aprofundaremos tais discussões no capítulo seguinte.

Essa passagem está inserida na teoria concernente à memória. Explicando-se o processo de memorização por meio dos loci podemos dizer que temos certa teorização acerca da fantasia. Cícero conta a anedota de Simônides (\$352-54) que foi contratado

\footnotetext{
${ }^{46}$ Cf. QUINTILIANO. Institutio Oratoria. VI, II, 29.
} 
para fazer um elogio ao anfitrião de um banquete, seu discurso, porém, não agradou ao contratante que pagou apenas a metade; depois de sair, a casa desabou e todos morreram, seus corpos ficaram irreconhecíveis, as famílias não poderiam então enterrálos. Simônides lembrava-se dos lugares em que cada um estava sentado por isso pôde identificar todas as pessoas presentes, resolvendo o problema. Os lugares aqui significam exatamente os topoi ou loci que devem ser empregados para auxiliar o orador na memorização do discurso.

Já observamos explicação semelhante na Retórica a Herênio, III, §29-30, onde a memória artificial constitui-se de lugares e imagens ("locis et imaginibus") e "quem tiver aprendido a mnemotécnica será capaz de colocar nos lugares o que ouviu e, recorrendo a eles, pronunciar de memória ${ }^{47,}$.

Segundo Cícero - conforme exposto na discussão da metáfora - a visão é o sentido mais agudo: acerrimum autem ex omnibus nostris sensibus esse sensum uidendi (§357). Aquilo que percebemos por meio dos ouvidos ou da reflexão podemos reter mais facilmente se é trazido ao espírito com a mediação dos olhos, mesmo que se trate de algo que não é realmente visto e não possa ser transmitido apenas pela reflexão, mas possa ser retido pela visão.

Tais formas necessitam de um "lugar" para ficar, esses loci devem ser empregados de maneira que facilitem a memorização de tais imagens, a fim de que uma só palavra permita representar um pensamento, assim como o pintor distingue o lugar dos objetos pelas diferenças na forma. Com as imagens conseguimos recordar as palavras; há, no entanto, algumas palavras que são difíceis de comparar com algo que as lembre; nesses casos, é necessário forjar imagens fixas e tal capacidade é própria do bom orador (questão recorrente no diálogo). O pensamento é lembrado por meio das imagens e a ordem por meio dos lugares.

Ainda que o termo fantasia não apareça nessa passagem, o procedimento adotado para a memorização remete ao exercício da fantasia, pois requer a visualização de imagens ausentes. Lembramos que a memória também está relacionada à fantasia aristotélica, uma vez que dela depende para armazenar as imagens recebidas pela visão, só assim se manifestarão posteriormente, quando ausentes.

Outras relações semelhantes são feitas no Orator, dentre as quais destacaremos algumas a seguir que remetem ao processo da fantasia. Em II, §8-9, Cícero fala sobre a

\footnotetext{
${ }^{47}$ Cf. nota 2.
} 
representação ideal que o escultor ou o pintor consegue fazer, ainda que não tenha um modelo; é o caso, por exemplo, das estátuas das divindades, pois não há um modelo, mesmo assim, o artista é capaz de representar a divindade próxima da perfeição e com grande beleza. Isso ocorre porque o artista é capaz de produzir uma imagem perfeita com a mente, algo que não pode ser percebido pelos sentidos; o mesmo ocorre com a oratória - o discurso perfeito pode ser produzido em nossas mentes, mas ao ouvi-lo temos apenas uma cópia que se aproxima desse ideal. Benedikstson ${ }^{48}$ afirma que a teoria da fantasia está aqui na sua forma embrionária ao tratar do ideal de beleza no lugar da verdadeira aparência física.

O caráter platônico de sua teoria é patente nesse tratado e afirmado diretamente por Cícero em XXIX, 101 (redeoque ad illam Platonis) na discussão acerca do orador ideal, aquele dotado de absoluta eloquência, embora esse homem ainda não tenha sido visto, podemos produzir esse ideal com a mente (animo tenere possumus), algo que só pode ser visto com os olhos da mente (mentis oculis). No entanto, se lembrarmos a história de Simônides que Cícero conta no livro II do De Oratore, entramos em conflito com a teoria platônica, pois ali ele assume uma postura semelhante aos estóicos, uma vez que o sentido da visão parte de objetos concretos para produzir uma representação verdadeira dos mesmos, ao passo que, em Platão, os sentidos não podem produzir algo verdadeiro, com sua essência ${ }^{49}$.

Vale mencionar também o começo do livro II do De Inuentione, a anedota de que Zêuxis, ao ser contratado pelos habitantes de Crotona para fazer uma pintura destinada ao templo de Juno, decidido a pintar Helena, solicitou que as jovens mais belas fossem selecionadas; ele escolheu cinco dentre as mais belas, porque nenhuma tinha a perfeição da beleza de Helena, mas seria possível produzir um retrato desta juntando as partes mais bonitas de cada uma. Como resultado, teríamos a Helena, representante da beleza perfeita, e um retrato sem éthos, cuja produção depende de um procedimento imagético que observamos corresponder à fantasia ${ }^{50}$.

A definição de fantasia na obra de Cícero aparece nas Academica, cuja discussão permeia todo o texto, o que torna indispensável seu estudo integral para a compreensão do conceito.

\footnotetext{
${ }^{48}$ BENEDIKSTSON, D. T. "Phantasia". In: Literature and the visual arts in Ancient Greece and Rome. Universe of Oklahoma Press: 2000 - Cf. pp. 173.

${ }^{49}$ A respeito dessa afirmação recomendo o texto “A Memória no De Oratore de Cícero". In: LEONARDI, Elisa Plattzack. A memória na Retórica Latina. São Paulo: FFLCH (Dissertação de Mestrado), 2003.

${ }^{50}$ Cf. MARTINS, P. "Cicero: The Picturing of a Rhetoric". passim.
} 
A exemplo de outras obras de Cícero já anteriormente expostas em nosso trabalho, Academica é um diálogo que expõe diversos pontos de vista. Essa obra discute acerca do conhecimento em várias correntes filosóficas, dentre as quais se destacam três estágios da academia - o ceticismo, o dogmatismo e a probabilidade de Filão -, além de contrapô-los às teorias epicurista e estóica. Portanto, não nos é apresentada uma conclusão a respeito dos assuntos discutidos, mas um panorama das diferentes teorias.

Vale ressaltar que Academica é comumente dividida em Priora e Posteriora, pois se sabe que houve duas edições, no entanto, nenhuma edição restou inteira, fazendo com que o texto ao qual temos acesso hoje seja um conjunto de ambas. A seguir, apresenta-se uma síntese das proposições desse diálogo que dizem respeito ao nosso estudo.

No primeiro livro, V, 20, vemos que o bem da mente (animus) consiste nas virtudes que levam à compreensão: a rapidez para aprender e a memória, ambas são propriedades da mente e do engenho. Mais adiante, relaciona-se a mente aos sentidos: o critério da verdade nasce dos sentidos, ainda que o julgamento da verdade não esteja aí, mas na mente (mens) - ela sozinha percebe o que é simples, de uma única forma e de semelhante natureza; é o que Platão chama "ideia".

Todos os sentidos são considerados fracos e lentos, uma vez que não percebem os objetos muito pequenos e, portanto, imperceptíveis, ou que estão em movimentação inconstante, teríamos, portanto, objetos da opinião.

Para Zenão, no que concerne à doutrina ética, as perturbações são voluntárias e experimentadas pelo julgamento da opinião.

Zenão fez algumas mudanças na lógica filosófica: em primeiro lugar, declarou que a sensação é a combinação de um tipo de impulso sofrido externamente com as visões recebidas pelos sentidos - tal impulso ele denomina fantasia, o que Cícero chama "visão" (uisum) - I, 40.

Nem todas as visões são confiáveis, mas apenas aquelas que possuem uma declaração própria dos objetos apresentados. Zenão foi o primeiro a utilizar o termo catalepton - apreensão ou compreensão - para algo aceito como verdadeiro. Aquilo que fosse apreendido pela sensação ele considerou a própria sensação, por sua vez, é algo tão firmemente apreendido que a razão não pode abalar - isso se chama conhecimento; a sensação não apreendida representa a ignorância, que é a fonte da opinião, semelhante à falsidade e à ignorância. 
Tal apreensão é considerada crível, logo, os sentidos também são confiáveis, visto que a apreensão é feita por meio deles; isso ocorre não por ter apreendido todas as características do objeto, mas porque não desconsidera nada que possa pertencer ao objeto. Além disso, a natureza concede como princípio e norma da ciência que a noção das coisas é impressa na mente. Ao passo que o erro, a precipitação, a ignorância, a opinião e a suspeita são considerados por Zenão como distintos da virtude e da sabedoria - aqui ele discorda da doutrina de seus predecessores.

Contudo, na doutrina platônica e em outros filósofos que o sucederam, dentre os quais estão Demócrito, Anaxágoras e Empédocles, observa-se a negação da cognição, da percepção e do aprendizado, uma vez que os sentidos são limitados, a mente é frágil e a vida é breve. A verdade, segundo Demócrito, estaria afundada num abismo, todas as coisas são medidas pelas opiniões e costumes - não há lugar para a verdade, todas as coisas estão escondidas nas trevas.

A doutrina estóica foi alvo de críticas por parte dos acadêmicos, pois não haveria necessidade de definir a cognição, a percepção ou a apreensão, esta última chamada catalepsis pelos estóicos; aqueles que fazem isso não agem cientificamente porque não há nada mais claro do que a enargia, a qual é chamada evidência ou perspicuitas pelos latinos. Nenhum discurso poderia ser mais claro do que a própria evidência e coisas tão claras não carecem de definição - II, VI, 17.

Filão de Larissa (da nova Academia) declarou que nada poderia ser apreendido, porém, se a visão (fantasia) da qual Zenão falara fosse impressa e representada a partir de um objeto, de maneira que não poderia ser de outro objeto, sua proposição estaria correta, pois não poderíamos apreender algo que seja percebido e compreendido se sua forma for falsa. Filão, no entanto, abole o critério entre o conhecido e o desconhecido que nos leva a concluir que nada possa ser compreendido.

Embora os sentidos possam ser considerados o lugar da verdade, uma vez que confiamos neles, quando pensamos nas artes, por exemplo, cada um percebe do seu modo. Os objetos são, portanto, percebidos não pela verdadeira sensação, mas por um tipo de sensação; essa é a classe de percepções que ocorrem na mente e não nos sentidos. A partir dessa classe de percepção que imprimimos nossa noção das coisas, sem a qual toda compreensão, investigação e discussão seriam impossíveis. 
Nada há de melhor que a cognição ${ }^{51}$ para confirmar a virtude de perceber e apreender. A partir da percepção, forma-se o conhecimento - é a compreensão não apenas de fatos, mas também do que é permanente e imutável -, a sabedoria e a arte de viver. Deve haver um princípio constituído para a sabedoria seguir quando ela age e esse primeiro princípio deve ser consistente com a natureza.

A razão iniciou a pesquisa, que por sua vez é a busca pelo conhecimento, e seu objetivo é a descoberta; ninguém descobre algo que seja falso, portanto, as coisas que permanecem continuamente incertas não podem ser descobertas. Descoberta significa a exposição das coisas obscuras, dessa maneira se dá o princípio da pesquisa e o resultado da percepção e apreensão. Essa é a definição da prova lógica: uma razão que conduz das coisas percebidas para algo que ainda não fora percebido.

Cícero expõe um questionamento: as visões podem ser falsas se não houver alguma noção para discerni-las, de que modo podemos dizer que alguém provou ou descobriu algo, ou se a prova lógica seria confiável?

É indubitável que nenhum dogma de um homem sábio possa ser falso, no entanto, isso não é suficiente para que não seja falso. As decisões devem ser fixas e estáveis, de maneira que não possam ser movidas por nenhuma razão.

Os homens são fortemente impressionados pelas visões, uma vez que direcionamos os sentidos para perceber os objetos. A própria mente, que é fonte das sensações e é ela própria uma sensação, tem uma força natural que a direciona para as coisas que a movem. Desse modo, algumas visões são reagrupadas para utilizá-las de uma vez, outras escondidas - estas constituem a fonte da memória -, enquanto todo o resto se une em sistemas pela similitude - a partir destas se formam os conceitos dos objetos. A razão, a prova lógica e uma inumerável multidão de fatos são somadas a isso, então aparece a percepção de todas essas coisas. É por meio dessa mesma razão feita por estágios que se alcança a sabedoria.

A mente do homem é extremamente bem adaptada para o conhecimento das coisas - isso envolve o máximo de cognição e a katalepsis. Portanto, a mente emprega os sentidos e ainda cria as ciências, quase como um segundo grupo de sentidos, além de reforçar a própria filosofia para que produza virtude.

\footnotetext{
${ }^{51}$ Traduzida por "Ética” por H. Rackam. London: Loeb Classical Library. 1979.
} 
Ainda a respeito disso, coloca-se a questão em torno da regra da verdade e da falsidade, pois se não temos a noção de ambas, devemos saber por qual razão não podem ser discernidas.

Se tivermos uma noção disso, deve haver uma diferença entre o verdadeiro e o falso, assim como há entre o certo e o errado. Caso não haja diferença, não há regra, e o homem que tem uma visão do verdadeiro e do falso não pode ter critério de verdade. Tendo abolido os meios pelos quais todas as coisas são julgadas, afirma-se não ter abolido as fontes restantes do conhecimento; é como dizer que um homem é privado de seus olhos, mas não dos objetos da visão. Como os objetos da visão são reconhecidos apenas pelos olhos, todo o resto é reconhecido pelas visões; mas eles são reconhecidos por uma marca que pertence especialmente ao que é verdadeiro, e não é comum ao que é verdadeiro e falso. Portanto, se considerarmos a visão provável e ainda desembaraçada, como defendia Carneades, ou alguma outra coisa como um guia para seguir, é necessário voltarmos à fantasia.

Os objetos percebidos e apreendidos pelos sentidos não podem ocorrer sem a confirmação; a faculdade de assentir é um ato voluntário.

Por outro lado, aquele que se recusar a exercitar a sensação ou a confirmação é privado da mente, que é necessária para clarificar as coisas vistas. Da mesma maneira que um animal não pode parar de buscar algo que lhe seja apresentado de acordo com sua natureza, a mente não pode parar de aprovar um objeto que lhe seja apresentado perspicuamente. A confirmação ocorre juntamente com a percepção, pois aquele que percebe algo o confirma imediatamente. Sem a confirmação, a memória, a ideia das coisas e as ciências são impossíveis; o mais importante de tudo é que nada existirá naquele que nada confirmar.

Antes de agir é essencial para nós experimentarmos alguma visão e a confirmarmos; portanto, aquele que abolir a visão ou a confirmação, abole toda a ação da vida.

A nova academia construiu uma ciência das visões definindo sua natureza e gêneros, em especial aqueles que podem ser percebidos e apreendidos. Algumas visões são verdadeiras, outras falsas, mas nenhuma visão pode ser de fato percebida. Toda a visão surge de um objeto verdadeiro e, da mesma maneira, poderia surgir de um objeto falso.

Os membros da nova academia são mais refutados quando assumem duas proposições que são violentamente discrepantes: algumas visões são falsas - isso 
claramente implica que algumas sejam verdadeiras; e que não há diferença entre as visões verdadeiras e falsas - contudo, a primeira suposição é de que há uma diferença. Portanto, as premissas são inconsistentes umas com as outras.

As coisas perspícuas e evidentes deparam-se com dois obstáculos. O primeiro obstáculo é que as pessoas não fixam e concentram suas mentes nos objetos perspícuos para que reconheçam como são claros. O segundo é que alguns são enganados por argumentos falazes e, incapazes de refutá-los, abandonam a verdade.

Os acadêmicos questionam a escola estóica no que concerne à afirmação de que algumas visões são enviadas por deuses, nos sonhos, por exemplo - pois afirmam que os estóicos contra os quais eles estão discutindo aceitam essas manifestações - como é possível uma divindade produzir falsas visões prováveis e não são capazes de produzilas mais próximas da verdade?

A mente (mens) é movida, por si mesma, por meio do pensamento e das visões que algumas vezes aparecem para os homens que estão dormindo ou enlouquecidos. É provável que a mente seja movida de tal maneira que não possa distinguir se as visões são verdadeiras ou falsas, ou ainda considere não haver diferença entre elas.

As visões inanes formadas pelo pensamento, as quais costumamos admitir no repouso, ou por causa do vinho ou da insanidade, são desprovidas de clareza. Quando alguém imagina um objeto, no momento em que se comove e recorda para si, não percebe imediatamente a diferença entre as visões perspícuas e as inanes.

Contudo, pode-se dizer que enquanto experimentamos as visões durante o sono, elas têm a mesma aparência das que vemos quando estamos acordados. No entanto, há uma diferença entre elas: quando estamos adormecidos, não temos a mesma força e integridade na mente ou nos sentidos de quando estamos acordados; até mesmo os homens que estão sob a influência do vinho, não tomam as mesmas decisões de quando estão sóbrios - ficam duvidosos e hesitantes, as coisas vistas são confirmadas de maneira mais fraca e, quando já dormiram, percebem o quão superficiais são as visões. O mesmo ocorre com a pessoa insana. O homem sábio num ataque de loucura contémse para não aceitar as falsas visões.

Algo que exista pode ser apreendido e o homem sábio nunca opina ou assente algo que é falso ou desconhecido.

Há um questionamento que poderia ser proposto a Zenão a respeito do valor do homem sábio: o que aconteceria se o sábio fosse incapaz de perceber qualquer coisa e que sua característica fosse de não formar uma opinião? Para Zenão, o homem sábio se 
abstém de formar uma opinião, pois é preciso perceber os objetos. Trata-se de uma visão impressa, selada e construída a partir de um objeto real, de acordo com a realidade.

Para Epicuro, se alguma vez um dos sentidos mentiu, nenhum sentido jamais terá crédito; nada pode ser percebido se nem mesmo os sentidos reportam a verdade.

O sentido da visão tem limitações, logo, algumas mentiras pertencem à opinião e não à visão. Podemos testemunhar falsamente a respeito de algo que vemos, dada a nossa posição, tal como o sol que é muito maior do que a terra e, mesmo assim, nos parece pequeno. Contudo, para Epicuro, os olhos não mentem, portanto, o tamanho deveria ser aquele que vemos.

Ainda que haja objetos parecidos, tais como as pessoas, as várias estátuas de um mesmo indivíduo, as marcas resultantes do selo de um único anel, enfim, não podem ser iguais. Devemos formar opinião a respeito, sem receio, pois cada um percebe de maneira distinta: o pintor vê coisas que não somos capazes de ver, da mesma maneira que um músico reconhece a canção na primeira nota.

Como já mencionamos anteriormente, durante o sonho ou num momento de loucura, as visões não são verdadeiras, mas a pessoa recebe tais visões como se fossem reais. A questão que se coloca não é o tipo de recordação que se experencia durante a visão, mas como é a visão no momento em que se manifesta.

Carneades defende que há dois gêneros de visão: aquelas que podem ser percebidas (katalepticai) e as que não podem (akataleptkai); aquelas que são prováveis (pithanai) e as que não são (apithanai). Não existe fantasia que resulte em percepção, mas muitas resultam no julgamento de probabilidade; pois é contrário à natureza que nada seja provável. O homem sábio, portanto, determinará como espécie provável, se nada se apresentar como contrário a essa probabilidade. De fato, as pessoas sábias seguem o provável, apreendendo, percebendo e confirmando as coisas que são semelhantes às verdadeiras.

Os estóicos afirmam que muitas coisas são falsas e extremamente diferentes daquilo que aparentam para os sentidos; o princípio de Epicuro é que se alguma visão for falsa, então nada pode ser percebido; os acadêmicos, por sua vez, dizem que há falsas visões.

Para os acadêmicos, algumas coisas podem ser percebidas e outras não, porque muitos objetos falsos, ainda que prováveis, não podem ser percebidos e apreendidos. Eles não desconsideram os sentidos, não disseram que a cor, o sabor ou o som não 
existam, mas discutem que tais visões não contêm uma marca própria que não possa ser encontrada em outro lugar.

Na discussão acerca da lógica, temos um panorama do que seria o critério da verdade: para Protágoras, o critério é aquilo que parecer verdadeiro para cada um; os Cirenaicos dizem que não há critério, com exceção das comoções; Epicuro coloca todo tipo de julgamento nos sentidos e noção das coisas e no prazer; Platão, no entanto, diz que todo julgamento da verdade, e a própria verdade, está separada das opiniões e dos sentidos e pertence ao pensamento e à mente.

\section{Anônimo - Do Sublime}

O tratado Do Sublime traz também uma definição a respeito da fantasia, no capítulo $\mathrm{XV}^{52}$ :

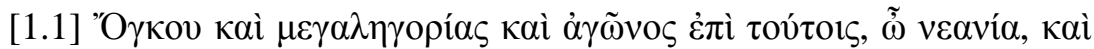

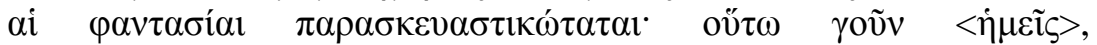

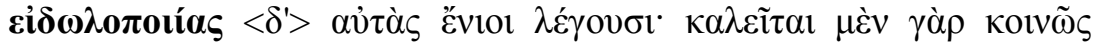

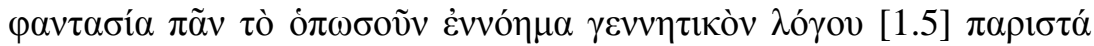

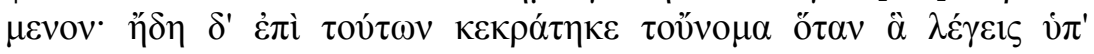

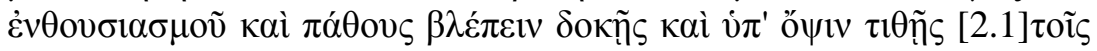

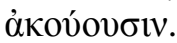

1. Também as fantasias, jovem amigo, são muito produtivas de majestade, grandiloquência e vigor. Pelo menos, nesse sentido é que alguns as chamam idolopéias; com efeito, chamamos fantasia indiferentemente todo pensamento que, de qualquer maneira, ocorra capaz de gerar uma palavra; mas hoje em dia o termo prevalece nos casos em que, inspirado e emocionado, parece-te estares vendo o de que falas e o pões sob os olhos dos ouvintes.

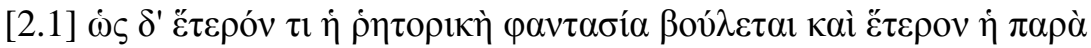

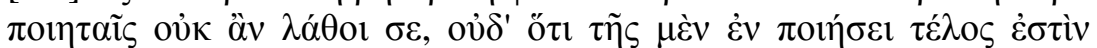

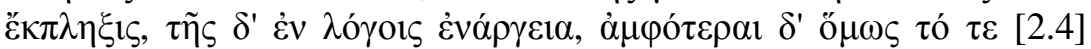

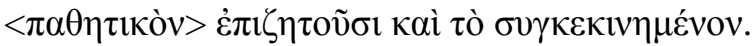

2. Que a fantasia tem um objetivo na oratória e outro na poesia não te passa despercebido, nem que o seu fito, na poesia, é maravilhar e, na oratória, dar vividez, mas uma e outra, além desses efeitos, procuram, não obstante, ao mesmo tempo, excitação [...].

\footnotetext{
${ }^{52}$ Cf. nota 16.
} 


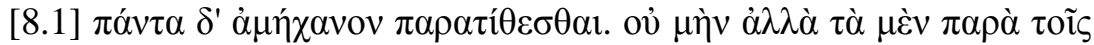

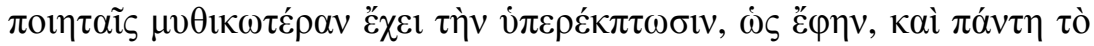

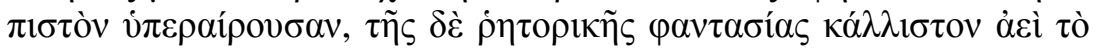

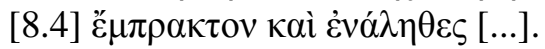

8. Exemplificar tudo seria impraticável. Todavia, os exemplos colhidos nos poetas, como eu dizia, encerram uma exageração mítica, que transcende por demais a credibilidade, enquanto o mais belo da imaginativa oratória consiste sempre em sua possibilidade e verossimilhança $[\ldots]$.

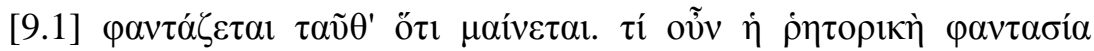

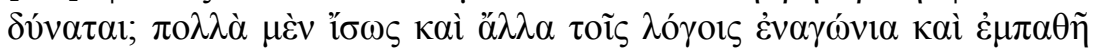

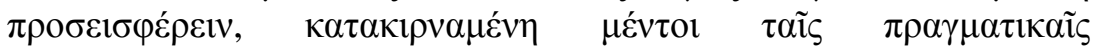

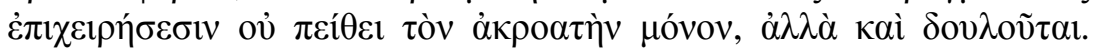

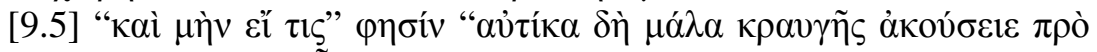

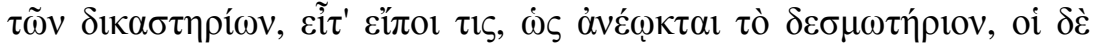

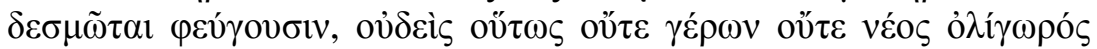

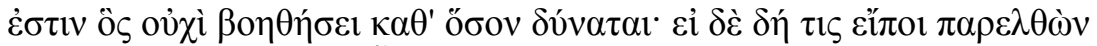

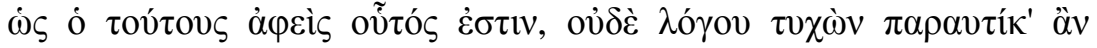

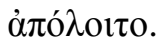

9. Qual, então, o condão da fantasia na oratória? Talvez carrear para os discursos grande variedade de lances veementes e patéticos; misturada à argumentação real, sobre convencer os ouvintes, avassalaos. "Sem dúvidas, diz Demóstenes, se, neste mesmo instante, se ouvisse um alarido diante do tribunal e alguém então dissesse 'Abriram as portas da cadeia e os presos estão escapando', não há jovem ou velho tão negligente que não acudisse na medida de suas forças; e mais, se alguém assomasse para dizer 'foi esse homem quem os soltou', o indicado seria morto no mesmo instante, sem uma palavra de defesa."

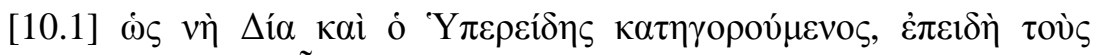

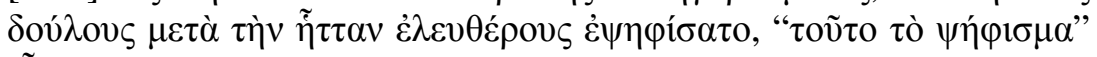

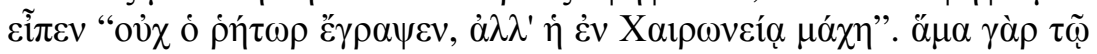

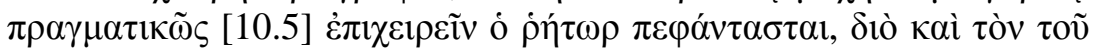

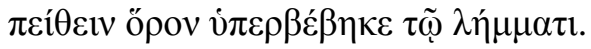

10. Foi assim, por Zeus! Que, acusado em justiça por ter decretado a libertação dos escravos depois da derrota, Hoperides disse: "Esse decreto não foi o orador quem o propôs, foi a batalha de Queronéia." Ao mesmo tempo que arrazoava, o orador empregou a imaginação, de sorte que, com esse pensamento, foi além do alcance da persuasão.

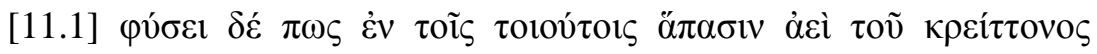

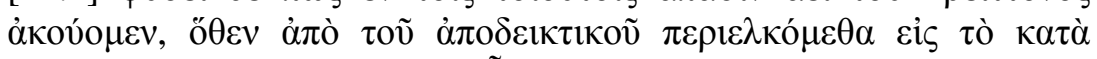

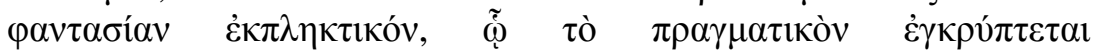

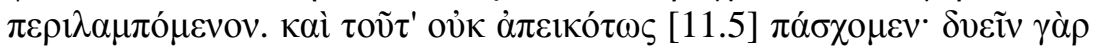




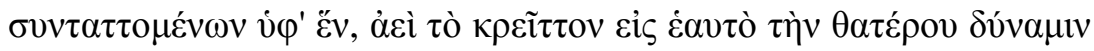
$\pi \varepsilon \rho 1 \sigma \pi \tilde{\alpha}$.

11. Em todos os casos semelhantes, naturalmente sempre ouvimos a palavra mais forte; assim, somos distraídos da demonstração para o efeito impressionante da fantasia, que ofusca a argumentação real com o brilho difundido em derredor. O que se passa conosco é normal; postas lado a lado duas causas, sempre a mais forte atrai para si o poder da outra.

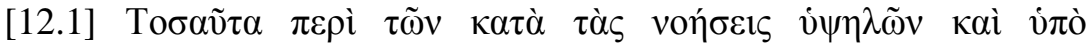

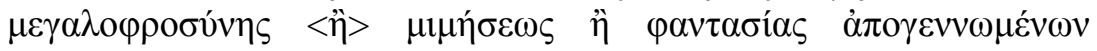

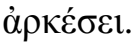

12. É quanto bastará a respeito do sublime nos pensamentos, gerado pelos sentimentos elevados, pela imitação ou pela fantasia.

Outra terminologia admitida no tratado para a fantasia é idolopeia, essa, por sua vez, é conhecida como um dos procedimentos da prosopopeia, claramente um tipo de écfrase que exporemos mais adiante. "Idolopeia" é empregada aqui como sinônimo de "produtora de imagem", visto que o discurso ultrapassa o âmbito verbal.

A definição da fantasia segue a mesma lógica das teorias já apresentadas de que o discurso quase se apresenta visualmente; portanto, algo ausente se torna presente. A função da fantasia é de comover o ouvinte que, como já vimos, é afetado mais fortemente por meio da visão. Emprega-se também para deleitar o público, seja na oratória ou na poesia, em cada uma com finalidade diferente, pois na poesia se exagera com o intuito de maravilhar, ao passo que na oratória se quer provar a argumentação proposta.

O mecanismo da fantasia na oratória torna o discurso mais crível e mais comovente ao mesmo tempo. O público distrai-se da demonstração, pois a fantasia ofusca a verdadeira argumentação, isso vai ao encontro da proposição citada anteriormente de que "a luz encobre a sombra" (XVII, 3), assim, o poder de persuasão é maior com a fantasia do que com qualquer outra prova.

$* * *$

A fantasia, embora fundamental para a compreensão dos mecanismos ecfrásticos, é um assunto cuja discussão concerne à filosofia. O processo da fantasia 
envolve a percepção sensorial, cujo meio é físico, e a conjunção de elementos inerentes ao ser humano, tais como a razão, a opinião e o pensamento.

Embora haja divergências entre as diferentes doutrinas, como ficou exposto, sobretudo, na compilação de Sexto Empírico e na Academica de Cícero, alguns aspectos estão presentes em grande parte delas. Acerca dos diferentes postulados da fantasia, Ildefonse ${ }^{53}$ as resume da seguinte maneira:

Em primeiro lugar, é necessário distinguir a phantasia estóica, ou representação, e a phantasia aristotélica, ou imaginação, produtora de imagens (phantasmata). A palavra phantasia não tem um status particular em Platão, que só utiliza o substantivo equivalente do verbo phainesthai. Foi Aristóteles que, primeiramente, em seu tratado $D a$ Alma, definiu a phantasia como uma faculdade intermediária entre a sensação e o pensamento e que, em princípio, só entra em funcionamento após o desaparecimento do objeto da sensação. Como a sensação, a phantasia, a imaginação, pode ser verdadeira ou falsa. (pp.70)

Platão adota termos que pertencem ao mesmo campo semântico da fantasia para se referir a fatos enganosos, os quais não são bem vistos na sua teoria; principalmente porque a fantasia se manifesta pela associação visual de uma imagem.

Aristóteles, por sua vez, define a fantasia como um dos processos que residem na alma, constituindo um exercício de imaginação que requer percepção, intelecção, opinião e memória.

A fantasia na doutrina estóica gera algumas constrovérsias em sua definição; observa-se que há certa variedade de espécies, mas a que se destaca é a compreensiva, que apreende a realidade porque está de acordo com o objeto.

A definição da fantasia em Do Sublime a distingue em dois tipos: retórica e poética. Remete à classificação do símile que propomos anteriormente, insere-se, portanto no âmbito tanto da oratória como da poesia, aproximando-se mais do conceito de enargia.

Embora o sentido da visão seja peça indispensável para o processamento da fantasia, outro elemento essencial é a alma, visto que nela residem as imagens do repertório mnemônico, necessário para a presentificação da imagem.

Compreendemos a importância do mecanismo quando observamos o embate entre as correntes filosóficas destacadas por Sexto - a fantasia é mais um elemento

\footnotetext{
${ }^{53}$ Cf. nota 43.
} 
inserido na busca pelo critério da verdade, discussão logicamente ampla na filosofia e de difícil conclusão.

\section{I.4. ENARGIA/ EVIDÊNCIA}

\section{Cícero}

Já tendo visto algumas proposições de Cícero nos tópicos dedicados à amplificação, à metáfora e à fantasia, retomaremos esses conceitos para explicar a evidência.

Na obra de Cícero, podemos observar conceitos relacionados à evidência a partir das inúmeras comparações da oratória com as artes não-verbais (pintura e escultura) que ele efetua, além das passagens em que trata da visão, como já ressaltamos; porém, não temos menção direta ao termo em seus tratados; contudo, mais tarde, a Institutio Oratoria de Quintiliano nos fornece a sistematização do conceito e, como veremos, com base nas proposições de Cícero.

As virtudes da elocução, conhecidas como lumina, são apresentadas no $D e$ Partitione Oratoria, §19, dentre as quais está o brilho (illustre) que permite quase colocar diante dos olhos os fatos dos quais se fala, uma vez que a visão é o sentido mais afetado pelo brilho:

20. Illustris autem oratio est si et uerba grauitate delecta ponuntur et translata et superlata et ad nomen adiuncta et duplicata et idem significantia atque ab ipsa actione atque imitatione rerum non abhorrentia. Est enim haec pars orationis quae rem constituat paene ante oculos, is enim maxime sensus attingitur: sed ceteri tamen, et maxime mens ipsa moueri potest. Sed quae dicta sunt de oratione dilucida, cadunt in hanc illustrem omnia; est enim pluris aliquanto illustre quam illud dilucidum: altero fit ut intellegamus, altero uero ut uidere uideamur.

E o discurso é brilhante se são colocadas palavras selecionadas de acordo com a gravidade, metaforizadas, hiperbólicas, epítetos, duplicadas, com os mesmos significados e que não sejam alheias à própria ação e da imitação dos assuntos. Com efeito, esta é a parte do discurso que é capaz de colocar o assunto praticamente diante dos olhos, esse é, com efeito, o sentido mais atingido: porém, os outros e, sobretudo, a própria mente, podem ser movidos. Mas as coisas que foram ditas acerca do discurso claro, todas convêm para este, o brilhante; com efeito, o discurso brilhante é um tanto maior do que o 
claro: por um, compreendemos, por outro, parecemos verdadeiramente ver. $^{54}$

As comparações com as artes visuais e a importância da visão são temas recorrentes no livro III do De Oratore. No §25, os sentidos são mencionados como fonte de deleite: na natureza há muitas coisas que, embora distintas, são dotadas de aspectos em comum dignos de louvor, tais como os sentidos - com a audição somos deleitados pelo som, ainda que se trate de coisas diversas; da mesma forma, a visão reúne um número quase incontável de prazeres, deleitando de diversas maneiras; assim segue com os outros sentidos. A diversidade de prazeres é também atribuída às artes mudas e aos poetas, os quais têm relação próxima com os oradores - os sentidos aqui servem apenas como paralelo para mostrar que os oradores podem ter estilos diferentes e, ainda assim, são agradáveis.

A afirmação acerca da agudeza da visão, já mencionada no livro II do $D e$ Oratore, é retomada no $\$ 160$ do livro III, pois a recepção da metáfora é mais intensa na visão do que nos demais sentidos, uma vez que põe diante dos olhos coisas que, na realidade, não são vistas (illa uero oculorum multo acriora, quae ponunt paene in conspectu animi quae cernere et uidere non possumus.). No $\S 163$, chega a falar em "olhos da mente" (mentis oculi) que nos transportam mais facilmente para as coisas que já vimos do que as que conhecemos apenas de ouvir, assim, o maior mérito da metáfora ocorre quando ela atinge nossos sentidos.

Em dada passagem, §96-100, o excesso de ornato pode, depois de um momento de deleite, cansar o público durante o discurso oratório, da mesma forma que as cores muito fortes de uma pintura cansam a vista depois de um breve momento; cita, ainda, exemplos com outros sentidos para reforçar essa ideia. Portanto, a ornamentação do discurso não deve ser excessiva se pretende deleitar o ouvinte durante toda sua duração.

No §202, na teorização acerca das figuras de pensamento, encontramos uma expressão semelhante ao proposto no De Partitione Oratoria, 20. A explicação clara é capaz de expor os feitos diante da vista e, juntamente com a commoratio, figura que consiste em deter-se num só assunto, ilustra e amplifica.

No De Optimo Genere Oratorum, Cícero já estabelecera várias relações de comparação para tratar do orador perfeito, o pintor, logicamente, é um dos elementos de comparação. Em II, 6, ele comenta que o orador mais perfeito é superior em todos os

\footnotetext{
${ }^{54}$ Tradução nossa.
} 
estilos, mas o orador que não é, não deixa de ser um orador, com o pintor ocorre o mesmo, não importa que seja inferior a outro no mesmo estilo, ele ainda é pintor. Em IV , 11, o discurso pode ser criticado por alguém que não seja orador, da mesma forma que a pintura pode ser criticada por alguém que não seja pintor; mesmo assim, ainda que não saiba pintar, saberá julgar, o que não parece ocorrer na oratória, pois o discurso ornado e elevado pode causar fastio e não agradar aos que não têm capacidade para julgá-lo.

Encontramos os termos enargia e evidência na Academica, livro II - Lucullus VI, 17, como já mencionamos essa passagem, basta destacar o que concerne à evidência. Discute-se acerca da katalépsis dos estóicos, ou comprehensio, também chamada aqui de cognitio ou perceptio. Em dado momento, representantes da filosofia acadêmica, numa crítica à teoria estóica, não consideravam necessário definir a katalépsis, porque nada haveria de mais claro do que a enargia (quod nihil esset clarius enargeiái), ou evidência (perspicuitas), - nenhum discurso poderia ser mais claro do que a própria evidência (orationem nullam... inlustriorem ipsa euidentia reperiri posse) e, dessa maneira, as coisas expressas nele não careceriam de definição.

\section{Quintiliano}

No tratado de Quintiliano não só encontramos a designação da evidência, como esse procedimento é equivalente a outros, dentre os quais estão a fantasia e a enargia. Acerca da primeira muito já foi falado; quanto a segunda trataremos agora, embora saibamos que a palavra expressa um significado relacionado às questões da visualização, algo como "clareza", "nitidez" - com esse significado é empregada, por exemplo, como adjetivo em vários diálogos platônicos em contextos que tratam da visão e de imagens.

Destaco a seguir as passagens da Institutio Oratoria que nos interessam:

IV, II, 63-5 Sunt qui adiiciant his euidentiam, quae enárgeia Graece uocatur. 64. [...] Euidentia in narratione, quantum ego intelligo, est quidem magna uirtus, cum quid ueri non dicendum, sed quodammodo etiam ostendendum est; sed subiici perspicuitati potest, quam quidam etiam contrariam interim putauerunt, quia in quibusdam causis obscuranda ueritas esset; quod est ridiculum. 65. Nam qui obscurare uult, narrat falsa pro ueris, et in iis quae narrat debet laborare, ut uideantur quam euidentissima. 
Há alguns que a tais virtudes acrescentam a evidência (da narração), que é chamada pelos gregos de enargia. 64. [...] A evidência na narração é, até onde entendo, certamente, uma grande virtude quando não se deve dizer a verdade, mas também, de alguma maneira, mostrar aos olhos; mas pode integrar a clareza, entretanto, alguns julgaram que a evidência fosse prejudicial, porque a verdade deveria ser obscurecida em certas causas; o que é um absurdo! 65. Com efeito, quem quer obscurecer, narra os fatos falsos no lugar dos verdadeiros e deve trabalhar naqueles fatos que narra para parecer o mais visível possível.

VI, II, 29 [...] Quas phantasías Graeci uocant, nos sane uisiones appellemus, per quas imagines rerum absentium ita repraesentantur animo, ut eas cernere oculis ac praesentes habere uideamur. Has quisquis bene conceperit, is erit in adfectibus potentissimus.

[...] Aquilo que os gregos chamam de phantasíai, nós certamente chamamos de visões, pelas quais as imagens das coisas ausentes são de tal modo representadas na alma, que parecemos vê-las com os olhos e tê-las presentes. Quem quer que as conceba bem, será o mais poderoso nos afetos.

VI, II, 32 Insequitur enárgeia, quae a Cicerone illustratio et euidentia nominatur, quae non tam dicere uidetur quam ostendere; et adfectus non aliter, quam si rebus ipsis intersimus, sequentur.

Segue-se a enargia, que é chamada por Cícero de illustratio ou evidência, que parece não tanto dizer, mas mostrar; e, não de outro modo, os afetos se seguirão, como se estivéssemos presentes nos próprios acontecimentos.

VIII, III, 61-70 [...] Itaque enárgeian, cuius in praeceptis narrationis feci mentionem, quia plus est euidentia uel, ut alii dicunt, repraesentatio quam perspicuitas, et illud patet, hoc se quodammodo ostendit, inter ornamenta ponamus. 62. magna uirtus est res de quibus loquimur clare atque, ut cerni uideantur, enuntiare. Nom enim satis efficit neque, ut debet, plene dominatur oratio, si usque ad aures ualet atque ea sibi iudex, de quibus cognoscit, narrari credit, non exprimi et oculis mentis ostendi. 63. Sed quoniam pluribus modis accipi solet non equidem in omnes eam particulas secabo, quarum ambitiose a quibusdam numerus augetur, sed maxime necessarias attingam. Est igitur unum genus, quo tota rerum imago quodammodo uerbis depingitur: "Constitit in digitos extemplo arrectus uterque" et cetera, quae nobis illam pugilum congredientium faciem ita ostendunt, ut non clarior futura fuerit spectantibus. 64. Plurimum in hoc genere sicut in ceteris eminet Cicero. An quisquam tam procul a concipiendis imaginibus rerum abest, ut non, cum illa in Verrem legit, "Stetit soleatus praetor populi Romani cum pallio purpureo tunicaque talari muliercula nixus in litore", non solum ipsos intueri uideatur et locum et habitum, sed quaedam etiam ex iis, quae dicta non sunt, sibi ipse 
adstruat?65. Ego cete mihi cernere uideor et uultum et oculos et deformes utriusque blanditias et eorum qui aderant tacitam auersationem ac timidam uerecundiam. 66. Interim ex pluribus efficitur illa quam conamur exprimere facies, ut est apud eundem (namque ad omnium ornandi uirtutum exemplum uel unus sufficit) in descriptione conuiuii luxuriosi: "Videbar uidere alios intrantes, alios autem exeuntes, quosdam exuino uacillantes, quosdam hesterna ex potatione oscitantes. Humus erat immunda, lutulenta uino, coronis languidulis et spinis cooperta piscium”. 67. Quid plus uideret qui intrasset? Sic et urbium captarum crescit miseratio. Sine dubio enim, qui dicit expugnatam esse ciuitatem, complectitur omnia quaecunque talis fortuna recipit, sed in adfectus minus penetrat breuis hic uelut nuntius. 68. At si aperias haec, quae uerbo uno inclusa erant, apparebunt effusae per domus ac templa flammae et ruentium tectorum fragor et ex diuersis clamoribus unus quidam sonus, aliorum fuga incerta, alii extremo complexu suorum cohaerentes et infantium feminarumque ploratus et male usque in illum diem seruati fato senes; 69. tum illa profanorum sacrorumque direptio, efferentium praedas repetentiumque discursus et acti ante suum quisque praedonem catenati et conata retinere infantem suum mater et, sicubi maius lucrum est, pugna inter uictores. 70. Licet enim haec omnia, ut dixi, complectatur euersio, minus est tamen totum dicere quam omnia. Consequemur autem, ut manifesta sint, si fuerint uersimilia; et licebit etiam falso adfingere quidquid fieri solet. Continget eadem claritas etiam ex accidentibus: "Mihi frigidus horror/ Membra quatit, gelidusque coit formidine sanguis" et "Et trepidae matres pressere ad pectora natos".

[...] Desse modo, consideremos a enargia, da qual fiz menção nos preceitos da narração, entre os ornamentos, porque a evidência ou, como alguns dizem, a repraesentatio, é mais do que a clareza, essa, de certa maneira, se mostra, ao passo que, aquela, se expõe diante dos olhos. 62. É uma grande virtude enuncia claramente os fatos a respeito dos quais se fala e de modo que pareçam ser vistos. Com efeito, o discurso não satisfaz suficientemente nem, como deve, domina plenamente, se sempre prevalece sobre os ouvidos e se o juiz acredita que sejam narrados para si os fatos que julga, em vez de expressos e mostrados aos olhos da mente. 63. Mas porque é de costume admitir muitos tipos, certamente, não passarei por todas as partes, das quais a quantidade é aumentada por alguns com ostentação, mas me ocuparei das mais necessárias. Portanto, há um gênero com o qual a imagem inteira das coisas é pintada, de alguma maneira, pelas palavras: "Imediatamente, ambos permaneceram erguidos nos pés" [Eneida, V, 426]. E outras que mostram, dessa maneira, o retrato dos lutadores combatentes, de modo que não teria sido mais claro se fôssemos espectadores. 64. Cícero sobressai-se nesse gênero assim como em outros. Acaso alguém é tão incapaz de conceber imagens que, ao ler aquela passagem das Verrinas - "o pretor do povo romano, de sandália, ficou de pé na praia com o manto púrpuro e a túnica até o tornozelo, apoiado numa mulherzinha" - não creia que vê as próprias pessoas, o local, o traje, e por si mesmo não forme algumas imagens até daquilo que não foi dito? $\mathbf{6 5}$. Eu, certamente, pareço ver o rosto, os olhos, os afagos vergonhosos de ambos, a tácita aversão e o tímido constrangimento daqueles que estavam presentes. 66. Às vezes, aquela 
imagem que nos esforçamos para exprimir é produzida a partir de muito mais coisas, como encontramos no mesmo autor (porque ele é mais do que suficiente para exemplificar todas as virtudes da ornamentação), na descrição de um banquete luxurioso: "Eu parecia ver algumas pessoas entrando, outras, porém, saindo, algumas cambaleantes por causa do vinho, outras ociosas por causa da bebedeira da véspera. $\mathrm{O}$ chão estava imundo, coberto de vinho, cheio de coroas inertes e de espinhas de peixe". 67. O que mais veria quem entrasse? Assim também a compaixão cresce com a captura das cidades. Pois, sem dúvida, quem diz que uma cidade foi subjugada, compreende tudo aquilo que tal fortuna admite, mas como o anúncio nesse caso é breve, penetra menos nos afetos. 68. Mas se expuseres estas coisas que foram encerradas numa única palavra, se apresentarão à vista as chamas espalhadas pelas casas e templos, o estrondo dos tetos desabando, certo som de diversos clamores, a fuga incerta de uns, outros unidos no último abraço dos seus, os lamentos das crianças e mulheres e, tristemente, os velhos que estavam salvos até aquele dia, durante a destruição; 69. Então aquela pilhagem das coisas profanas e sagradas, dos que transportam os despojos e dos que recomeçam a pilhagem, os acorrentados levados diante de algum ladrão seu, a mãe esforçando-se para manter seu filho, se em algum lugar o lucro é maior há luta entre os vencedores. 70. Com efeito, é lícito expor todas essas coisas, como disse, pois ainda que a conquista [da cidade] envolva tudo, dizer o todo é menos do que dizer cada parte. E seguimos de modo que sejam evidentes, como se fossem verdadeiros; e será lícito também atribuir falsamente qualquer coisa que costuma ser feita. A mesma vividez resulte também dos acidentes: "O gélido terror abala todo meu corpo e o sangue torna-se gelado de medo" [Eneida, III, 29-30] e "E as mães temerosas carregavam as crianças junto ao seio" [Eneida, VII, 518].

VIII, III, 89 enérgeia confinis his (est enim ab agendo dicta) et cuius propria sit uirtus nos esse, quae dicuntur, otiosa.

A enérgeia, junto de seus semelhantes (é, pois, as coisas ditas da ação), da qual lhe seja própria a virtude de que as coisas que são ditas não sejam inúteis.

IX, II, 40 Illa uero, ut ait Cicero, sub oculos subiectio tum fieri solet, cum res non gesta indicatur, sed ut sit gesta ostenditur, nec universa, sed per partes; quem locum proximo libro subiecimus euidentiae, et Celsus hoc nomen isti figurae dedit. Ab aliis hypotýposis dicitur proposita quaedam forma rerum ita expressa uerbis, ut cerni potius uideatur quam audiri: "Ipse inflammatus scelere ac furore in forum uenit, ardebant oculi, toto ex ore crudelitas eminebat".

$\mathrm{Na}$ verdade, aquela (figura), como diz Cícero, "posta diante dos olhos" $" 55$ costuma se produzir então não quando se indica que algo foi realizado, mas que se exiba como foi feita, não de maneira completa,

\footnotetext{
${ }^{55}$ Butler (Loeb Classical Library) propõe como ocular demonstration, i.é, "demonstração ocular".
} 
mas em partes, paulatinamente; figura a que no último livro chamamos de evidência, e Celso deu este nome a tal figura. Outros dizem que é hipotipose, certa representação exposta de fatos, é expressa pelas palavras de modo que pareça antes ser vista, do que ouvida: "Ele veio para o fórum inflamado de crime e furor, os olhos ardiam, a crueldade mostrava-se em todo o rosto".

IX, II, 41 Nec solum quae facta sinta ut fiant, sed etiam quae futura sinta ut futura fuerint imaginamur. [...] Sed haec quidem translatio temporum, quae proprie metástasis dicitur, em diatypósei uerecundior apud priores fuit. Praeponebant enim talia "Credite uos intueri", ut Cicero, "Haec, quae non uidistis oculis, animis cernere potestis".

Não apenas as coisas que já foram feitas ou que sejam feitas, mas também as coisas que aconteçam no futuro ou que se imagine que acontecerão no futuro. [...] Mas esta "transferência de tempo", na verdade, que é chamada propriamente de metástase, existiu mais discretamente em diatipose entre os primeiros (oradores). Com efeito, diziam antes tais coisas "Acreditai que vedes", como Cícero, "Estas coisas, as quais não vistes com os olhos, podeis perceber com os (olhos) da alma". ${ }^{56}$

A evidência pode ser considerada uma virtude da narração capaz de torná-la mais clara, servindo não apenas como ornato que agrada, mas também contribuindo para a argumentação da causa em questão, pois mesmo que os fatos não sejam verdadeiros, devem parecer; portanto, não devem ser obscurecidos. Ao tratar da comoção do público, a fantasia, ou uisio, é um poderoso recurso uma vez que representa as coisas ausentes na alma e, assim, parecerão presentes.

A enargia, segundo Quintiliano, equivale à illustratio ou evidência de Cícero, que provoca o mesmo efeito da fantasia, tornando o público testemunha dos acontecimentos. A evidência é denominada também como a repraesentatio, ele ressalta que vai além da perspicuitas, pois é mais do que a exposição dos fatos, é exposição que os apresenta aos olhos.

Quintiliano nos fornece vários exemplos de evidência, a cena do pretor com sua amante e o banquete, extraídos de Cícero, a destruição de uma cidade, onde cada acontecimento é mencionado e a cada infortúnio nos comovemos mais; além de pequenos exemplos da Eneida que apenas indicam a situação, mas sabemos que estão situadas num contexto maior onde a cena é descrita, sobretudo as últimas passagens,

\footnotetext{
${ }^{56}$ Tradução nossa.
} 
cheias de expressões que reforçam a mesma ideia do pavor. Embora não fale diretamente da descrição, fica claro a partir dos exemplos o caráter descritivo para produzir a evidência, pois a riqueza de detalhes permite ao público compor com mais exatidão em sua mente.

A expressão sub oculos subiectio de Cícero corresponde à evidência (De Oratore, III, 53,202), mas novamente é comparada a outra figura - a hipotipose, da qual trataremos logo em seguida. A exposição dos fatos é feita por partes, ou seja, há certa ordem na sua demonstração para que vejamos cada ocorrência em seus detalhes. É possível narrar acontecimentos passados, presentes ou futuros, pois os fatos podem ser imaginados ainda que não sejam vistos ou não tenham acontecido: esse processo é o que se chama de translatio temporum ou metástase, usada em diatipose, termo que também significa "descrição" e que veremos na teoria da écfrase dos Progymnásmata.

Faz-se necessário citar aqui um comentário presente no texto de $\mathrm{Webb}^{57}$ a respeito do termo "metastasis", o qual só apareceria nas edições modernas de Quintiliano; o termo apropriado seria "metathesis" que quer dizer transferência de tempo, enquanto o significado técnico de metástase é "transferência de culpa".

O termo enérgeia também aparece em Quintiliano, cuja definição é compatível com o que se diz na Retórica de Aristóteles: trata-se da representação da ação, é importante lembrar tal conceito, pois vimos que onde aparece enérgeia na Retórica existe a dúvida se não seria "enargia".

Apesar da variedade de terminologia no tratado de Quintiliano, o objetivo é sempre transformar a narração em algo que possa ser visto durante sua enunciação nisso reside uma virtude da elocução. A função mouere sobrepõe-se na teoria da evidência de Quintiliano que a exemplifica em situações de interação entre o orador e o público. O gênero judiciário serve para ele como base para exemplificar os efeitos da figura, pois o orador falha se aparentar somente narrar os fatos, ele deve expressá-los para que os olhos da mente o vejam, dessa maneira, comove-se mais intensamente.

\section{Outros Retores Latinos}

A enargia também aparece em outros tratados de retórica, nos quais tem a acepção de figura. Destacamos a seguir exemplos de alguns desses $\operatorname{tratados}^{58}$ :

\footnotetext{
${ }^{57}$ WEBB, R. Ekphrasis, Imagination and Persuasion in Ancient Rhetorical Theory and Practice. Surrey: Ashgate. 2009. Cf. pp. 100.

${ }^{58}$ Tradução nossa.
} 


\section{Rufiniano. De Schematis Dianoeas}

15. Enárgeia est figura, qua formam rerum et imaginem ita oratione substituimus, ut lectoris oculis praesentiaeque subiciamus.

A enargia é a figura com a qual colocamos a forma e a imagem das coisas no discurso, para que as apresentemos aos olhos do leitor como se estivessem presentes.

\section{Isidoro. De Rhetorica}

33. Enargia est rerum gestarum aut quase gestarum sub oculis inductio, de qua locuti iam sumus.

A enargia é a indução das ações realizadas ou quase realizadas sob os olhos, a respeito da qual já falamos.

\section{Schemata Dianoeas. Quae ad Rhetores Pertinent.}

1. Enárgeia est imaginatio, quae actum incorporeis oculis subicit et fit modis tribus: persona, loco, tempore. Persona, cum absentem alloquimur quase praesentem. Vergilius: Nec tu carminibus nostris indictus abibis, Oebale. Loco, cum eum, qui non est in conspectu nostro tanquam uidentes demonstramus, ut: Hic Dolopum manus, hic saeuus tendebat Achilles. Tempore, cum praeterito utimur quase praesenti, ut: Apparent rari nantes in gurgite uasto.

Enargia é a imaginação que expõe a ação aos olhos incorpóreos e ocorre de três modos: pelo personagem, pelo lugar e pelo tempo. Pelo personagem, quando falamos ao ausente como se estivesse presente. Virgílio: "Nem tu, Ébalo, morrerás em silêncio em nossos versos". Pelo lugar, quando aquilo que não está na nossa vista, demonstramos como se estivéssemos vendo, tal como: "Aqui, o exército da Tessália, onde Aquiles furioso lutava". Pelo tempo, quando nos servimos de um fato pretérito como se estivesse no presente, como: "Raros nadadores aparecem no mar imenso".

Observa-se que o propósito atribuído à enargia é o mesmo em Cícero e Quintiliano e assim se estabeleceu na tradição retórica.

Com base nos exemplos de Quintiliano já se confirma a variedade temática da enargia, contudo, com base no excerto acima, constata-se que há certa classificação retórica da enargia aqui determinada pela pessoa, lugar e tempo - espécies que são confirmadas também por Quintiliano, ainda que não sistematizadas. ${ }^{59}$

59 Os Epicuristas também trataram da enargia, contudo, a relação da teoria epicurista com os procedimentos estudados na pesquisa parece mínima, visto que a enargia aqui tem um conceito distante do procedimento retórico verificado em Quintiliano como correspondente da evidência. Por essa razão, seguindo o conselho da banca examinadora, deixamos essa passagem em nota, pois é importante 


\section{I.5. HIPOTIPOSE}

\section{Quintiliano}

A partir de agora passaremos a tratar da hipotipose, considerada uma figura de pensamento que, por sua vez, é usada conjuntamente com figura de palavras, pois essas servem para compor aquela. Como foi dito por Quintiliano (IX, II, 40), a hipotipose produz o efeito de "expor diante dos olhos".

No livro IX da Institutio Oratoria, o autor discorre acerca das figuras de pensamento, onde podemos encontrar a definição da hipotipose. Como já vimos, ele afirma que o que Cícero chama de "sub oculos subiectio" é conhecido por evidência ou hipotipose, tal disposição diante dos olhos é produzida por meio da apresentação detalhada sobre o que se fala, é de tal maneira expressa verbalmente que o público tem a sensação de ver, não apenas ouvir.

No §41 temos que é possível imaginar não apenas fatos passados ou presentes, como também futuros ou que deveriam acontecer; esse processo é chamado aqui de translatio temporum (convém lembrar que o termo "translatio" equivale, como vimos, à metáfora grega), é denominado de metástase, usada mais discretamente pelos primeiros oradores por meio de diatipose, que significa "descrição vívida", destaca-se aqui o

mencioná-la. Assim como fizemos com a fantasia, expondo suas diversas acepções em filosofias distintas, é importante fazer o mesmo com os demais termos sempre que isso seja possível. Além disso, como contemporâneo do estoicismo, é interessante saber como a questão das sensações, tão cara ao nosso estudo, é tratada pela filosofia epicurista. O epicurismo defende a sensação como o mecanismo que nos transmite a verdade, o princípio de sua canônica baseia-se na "evidência" (enárgeia) daquilo que é sentido. Destacamos a seguir algumas citações da teoria epicurista:

A canônica epicurista possui três critérios de verdade: a sensação (aísthesis), a antecipação (prólepsis) e a afecção (páthos). A sensação surge a partir do contato entre um de nossos sentidos e a realidade e precede a razão, por isso não pode ser contrariada nem mesmo pela razão, pois esta é que advém da sensação. Nesse sentido é que a sensação é tida como evidência (enárgeia) que não pode ser refutada. Os sonhos são então considerados verdadeiros porque têm como base um dado concreto, já que o que não existe não afetaria a mente, contudo, a teoria epicurista é de caráter materialista e não trata detalhadamente dessa questão.

A antecipação é a apreensão imediata do real ou a opinião correta, ou mesmo um pensamento que desperta a lembrança de algo real que já conhecemos - a significação imediata e evidente (enargés) que temos ao nomear o objeto. No entanto, não se trata de uma simples recordação, pois, para antecipar o conceito que temos do objeto, precisamos conhecer por meio da experiência dos sentidos outros objetos dos quais se diferencia. Daí surge a noção de opinião, chamada também "suposição", que é verdadeira se a enárgeia a confirma ou não a contradiz e falsa no caso contrário.

Pouco se comenta a respeito das afecções, contudo, é suficiente para sabermos que o prazer é o que o homem deve buscar em sua vida, enquanto a dor deve ser evitada; ambos são também evidência da verdade transmitida pela sensação.

As apresentações intuitivas do pensamento (phantastikè epibolè tes dianoías) não constituem um assunto que esteja bem explicado nos textos de Epicuro; mas ao que parece é certo procedimento operado pela mente para projetar as verdades captadas pela sensação. 
exemplo de Cícero: "Estas coisas, as quais não vistes com os olhos, podeis perceber com os (olhos) da alma" (Haec, quae non uidistis oculis, animis cernere potestis). Tal figura tem algo de mais evidente, pois o fato parece realmente acontecer diante do público, não apenas parece ser narrado.

A descrição clara e expressiva de lugares é incluída no conceito da hipotipose, ao passo que outros a classificam como topografia. Mais adiante, apresenta-se o parentesco entre a hipotipose e outra figura, a etopeia, que consiste na representação dos costumes ou características das pessoas. Ela pode versar também a respeito dos ditos e dos fatos, quando diz respeito aos fatos está próxima da hipotipose. Tais proposições são observadas nas seguintes passagens ${ }^{60}$ :

IX, II, 44 Locorum quoque dilucida et significans descriptio eidem uirtuti adsignatur a quibusdam; alii topographían dicunt.

A descrição de lugares também clara e expressiva é indicada por alguns como a mesma virtude; outros a chamam de topografia.

IX, II, 58 Imitatio morum alienorum, quae ethopoiía uel, ut alii malunt, mimesis dicitur, iam inter leniores adfectus numerari potest; est enim posita fere in eludendo, sed uersatur et in factiis et in dictis. In factis, quod est hypotypósei uicinum [...].

A imitação dos costumes dos outros que uns chamam de etopeia ou, como outros preferem, mimese, já pode ser numerada entre os afetos mais brandos; com efeito, foi colocada inteiramente na diversão, mas versa também a respeito de fatos e de palavras. No que concerne aos fatos, está próxima da hipotipose [...].

Aqui cabe lembrar a proposição da demonstração e da descrição na Retórica a Herênio, termos correspondentes à hipotipose, ambos são ornamentos que servem para amplificar e comover, cuja finalidade se assemelha aos recursos que pretendem dar mais vivacidade ao discurso ${ }^{61}$ :

IV, 51 Descriptio nominatur, quae rerum consequentium continet perspicuam et dilucidam cum grauitate expositionem, hoc modo: "Quodsi istum, iudices, uestris sententiis liberaueritis, statim, sicut e cauea leo emissus aut aliqua taeterrima belua soluta ex catenis,

\footnotetext{
${ }^{60}$ Tradução nossa.

${ }^{61}$ Cf. nota 2 .
} 
uolitabit et uagabitur in foro, acuens dentes in unius cuiusque fortunas, in omnes amicos atque inimicos, notos atque ignotos incursitans, aliorum famam depeculans, aliorum caput obpugnans, aliorum domum et omnem familiam perfringens, rem publicam funditus labefactans. Quare, iudices, eicite eum de ciuitate, liberate omnes formidine; uobis denique ipsis consulite. Nam si istum impunitum dimiseritis, in uosmet ipsos, mihi credite, feram et truculentam bestiam, iudices, inmiseritis [...] Hoc genere exortationis uel indignatio uel misericordia potest commoueri, cum res consequentes comprehensae uniuersae perspicua breuiter exprimuntur oratione.

Chama-se descrição o ornamento que contém uma exposição perspícua, clara e grave das consequiências das ações, desta maneira: "Se com vossa sentença, juízes, livrardes este homem, imediatamente, como um leão solto da jaula ou outra besta hedionda liberada das correntes, ele correrá de um lado a outro do fórum, abocanhando nossos bens, atacando a todos, amigos e inimigos, conhecidos e desconhecidos, dilacerando o nome de uns, ameaçando a vida de outros, destruindo casas e famílais, destroçando os alicerces da República. Por isso, juízes, expulsai-o da cidade, livrai-nos do medo, enfim, zelai também por vós, pois se o deixardes ir impune, acreditaime, contra vós mesmos tereis atirado a fera truculenta e selvagem" [...] Com esse gênero de ornamento, pode-se suscitar indignação ou misericórdia quando todas as conseqüências reunidas se exprimem brevemente num discurso perspícuo.

IV, 68-9 Demonstratio est, cum ita uerbis res exprimimur, ut geri negotium et res ante oculos esse uideatur. Id fieri poterit, si, quae ante et post in ipsa re facta erunt, comprehendemus aut a rebus consequentibus aut circum instantibus non recedemus [...] 69. Haec exornatio plurimum prodest in amplificanda et conmiseranda re huiusmodi enarrationibus. Statuit enim rem totam et prope ponit ante oculos.

$\mathrm{Na}$ demonstração exprimimos um acontecimento com palavras tais que as ações parecem estar transcorrendo e as coisas parecem estar diante dos olhos. Pode-se fazer isso reunindo aquilo que houve antes, depois e na ocasião do ato, ou atendo-se a suas consequiências e circunstâncias [...] 69. Esse ornamento é muito útil para amplificar e apelar à misericórdia, pois, com uma narrativa desse tipo, expõe todo o ocorrido e o coloca diante dos olhos.

\section{Progymnásmata}

Hermógenes (provavelmente século II d.C.) menciona a hipotipose quando discorre acerca do lugar-comum, $§ 12$, em seus exercícios preparatórios de retórica. Constitui-se como uma das etapas desse procedimento: o lugar-comum serve para 
amplificar uma ação e a hipotipose, cujo significado aqui é de descrição vívida, é um dos meios que permite essa amplificação.

A hipotipose como um dos recursos adotados pelo lugar-comum nos faz considerar que os procedimentos ecfrásticos eram bastante utilizados, visto que o objetivo dos Progymnásmata era ensinar os principais procedimentos retóricos.

Com o mesmo propósito, Hélio Teão (I d.C.), também tratando do lugar-comum, $\S 109$, atribui esse caráter descritivo ao termo diatipose que, conforme já vimos, Quintiliano já incluíra na teoria acerca da hipotipose; portanto, reforça-se a relação entre os dois termos que aqui apresentam o mesmo significado.

\section{Outros Retores Latinos}

O termo diatipose também está presente em outros tratados de retórica e, a exemplo do que ocorre com a enargia, é tratada como figura. Como exemplo, temos ${ }^{62}$ :

\section{Áquila Romano. De Figuris Sententiarum et Elocutionis}

13 - Diatýposis, descriptio uel deformatio, ubi rebus subiectis personisque et formas ipsas et habitus describimus et exprimimus [...].

Diatipose, descrição ou representação, onde descrevemos e retratamos as formas mesmas e a compleição das coisas e personagens que são representadas [...].

\section{I.6. ÉCFRASE/ DESCRIÇÃO}

\section{Progymnásmata}

Hélio Teão inclui a écfrase, termo equivalente à descrição latina, entre os exercícios de retórica que devem ser ensinados aos jovens. Apresento a seguir um apanhado da sua teoria concernente à écfrase, entre os $\$ 118-20$ dos Progymnásmata. Segundo Teão, no §118, a écfrase é uma composição que expõe em detalhe e apresenta

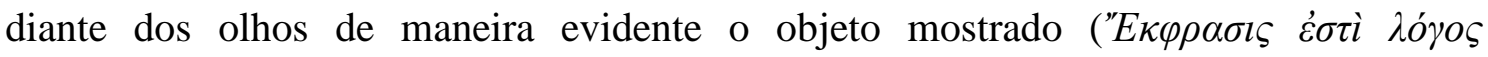

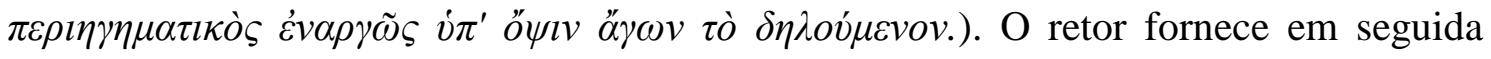
uma tipologia da écfrase:

\footnotetext{
${ }^{62}$ Tradução nossa.
} 
Personagens (prosopa): como fez Homero, por exemplo, "Era encurvado, de cute queimada e os cabelos bem crespos, / e tinha o nome de Euríbates." (Odisséia, 19, 246. Trad. C. A. Nunes). Os animais também são inseridos nessa categoria.

Ações (pragmata): guerra, paz, fome, epidemia, terremoto etc.

Lugares (topoi): praias, cidades, ilhas, desertos etc.

Épocas/ Tempo (chronoi): estações do ano e festividades.

Modos (tropoi): quais são os equipamentos, armas e máquinas da guerra, com relação aos preparativos de cada um, como na Ilíada, XVIII.

Temos ainda, no §119, que a écfrase pode ser mista como, por exemplo, no combate noturno da História da Guerra do Peloponeso de Tucídides, VII, 44 - a noite é uma circunstância temporal e o combate é uma ação:

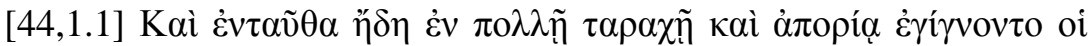

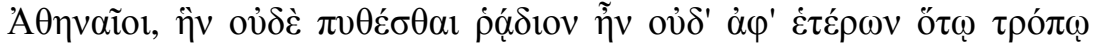

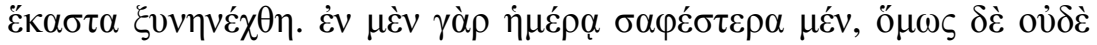

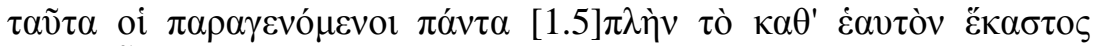

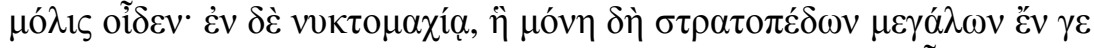

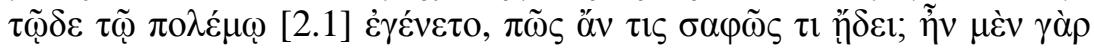

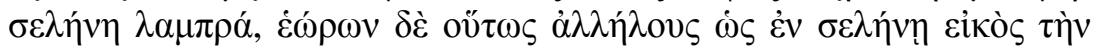

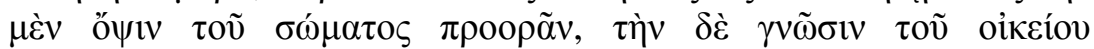

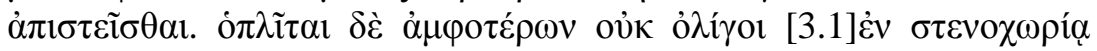

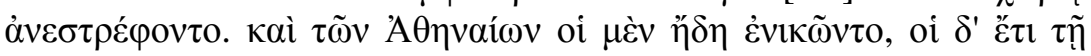

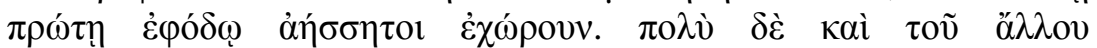

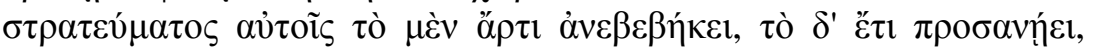

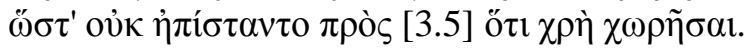

44, 1,1 A partir daquele momento a confusão e perplexidade entre os atenienses tornou-se tão grande que não foi fácil saber exatamente de cada lado como os acontecimentos se desenrolaram. Naturalmente as coisas são mais claras à luz do dia, mas mesmo assim as pessoas não percebem tudo que acontece, e cada um mal sabe o que ocorre em suas imediações; em uma batalha noturna, então - aquela foi a única nesta guerra disputada entre forças numerosas - como poderia alguém saber algo claramente? Embora a lua estivesse brilhante, os combatentes apenas podiam ver-se uns aos outros, como é normal ao luar: tem-se a visão de uma pessoa, mas não se confia no reconhecimento sequer das mais íntimas. Havia, além disto, um grande número de hoplitas de ambos os lados indo e vindo num espaço exíguo. Do lado ateniense alguns já estavam sendo derrotados, enquanto outros, ainda no primeiro ímpeto, continuavam avançando incontidamente; quanto ao grosso dos exércitos, as tropas em sua 
maioria apenas haviam terminado a escalada, enquanto outras ainda estavam subindo, sem saber portanto, a que grupo juntar-se (... ${ }^{63}$.

A classificação acima indica claramente que os elementos constitutivos da narração são os mesmos da écfrase, logo, a proximidade de ambas é evidente. Ao tratarmos da écfrase, sobretudo quando adotamos "descrição" como equivalente, devemos ter cuidado para não estigmatizá-la como a entendemos hoje.

Segundo Teão, este exercício de retórica aproxima-se do lugar-comum porque ambos não tratam acerca de um objeto definido, mas daquilo que é comum e geral; no entanto, o lugar-comum se refere a um indivíduo dotado de intenção, ao passo que a écfrase se faz quase sempre com seres inanimados e desprovidos de vontade. Outra particularidade é que no lugar-comum acrescentamos a nossa opinião, na écfrase a exposição das ações não apresenta opiniões, aparecem como são.

As ações são processadas descrevendo também os acontecimentos anteriores e posteriores; no caso da guerra examinam-se, primeiramente: as circunstâncias anteriores à guerra - a organização das tropas, os gastos, os temores, a devastação do país; em seguida, os fatos da guerra - ferimentos, mortes, duelos; e, por fim, as consequências a conquista e a escravidão de uns e a vitória de outros.

No caso dos lugares, épocas, modos ou personagens, junto com sua própria narração, teremos fontes de argumentos a partir da beleza, da utilidade e do prazer, como fez Homero no caso das armas de Aquiles, ao dizer que eram belas, poderosas e de aspecto admirável para os aliados, mas assustador para os inimigos:

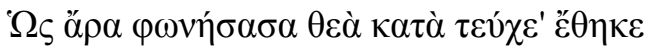

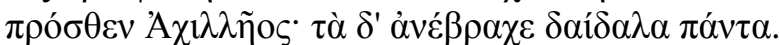

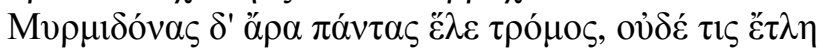

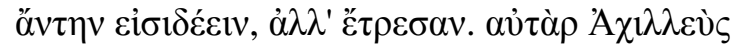

Pós ter falado, na frente de Aquiles a deusa coloca/ a refulgente armadura; ressoam as armas divinas./ Os valorosos Mirmídones ficam tomados de medo,/ sem que nenhum se atrevesse a fixá-la, a tremer afastando-se. (Ilíada, XIX,12-15. Trad. C. A. Nunes).

As virtudes da écfrase são, principalmente, a clareza (saphéneia) e a vivacidade (enárgeia), para que quase se veja o que é exposto, além disso, a exposição deve

\footnotetext{
${ }^{63}$ Tradução de Mário da Gama Kury. Brasília: Universidade de Brasília. 1982.
} 
adaptar-se ao tema, sem estender-se em aspectos desnecessários: se o tema for florido, árido ou assustador, que a expressão também seja.

Para finalizar, Teão declara que há quem defenda que esse exercício deve ser empregado na refutação e confirmação das écfrases feitas por outros autores. Porém, na opinião do retor, tal espécie de refutação e contestação pertence ao relato.

Nos Progymnásmata de Hermógenes temos também uma parte dedicada à écfrase, no §22 ele apresenta preceitos semelhantes aos de Teão, com poucas diferenças, propondo que, por exemplo, a paz e a guerra estão classificadas como circunstâncias e os exemplos são idênticos. A seguir, no §23, as principais virtudes da écfrase são também a clareza (saphéneia) e a vivacidade (enárgeia), necessárias para que a elocução provoque a visão do que se descreve por meio da audição.

Alguns dos autores mais rigorosos não consideram a écfrase um exercício preparatório, visto que era tratada na fábula, no relato, no lugar-comum e no encômio, pois tais modalidades também descrevem lugares, rios, ações e personagens. No entanto, alguns autores não medíocres - segundo Hermógenes - a reconhecem como um exercício; ele então prefere também incluí-la para não ser negligente.

Ainda vemos tais preceitos, mais tarde, nos Progymnásmata de Aftônio (IV d.C.), com a mesma definição e algumas particularidades na classificação como, por exemplo, as circunstâncias englobam as estações do ano (§37).

Da mesma maneira que a écfrase das ações segue uma ordem, a das personagens também deve ser sequencial - do princípio ao fim, ou seja, da cabeça aos pés; para as circunstâncias e lugares deve-se tratar dos elementos que os rodeiam e que estão neles.

A écfrase pode ser simples ou composta e nesse caso seria a junção da ação a uma circunstância, como uma batalha noturna. Essa definição é, portanto, igual ao que já foi proposto nos anteriores como mista.

Acerca do estilo da écfrase no §38, Aftônio afirma que ela deve ser simples e adornada por diversas figuras e que, com uma única palavra, seja capaz de reproduzir o objeto ao qual se refere.

Antes de passar para o próximo exercício, Aftônio apresenta um extenso exemplo de écfrase "do templo de Alexandria junto à Acrópole".

Durante a Segunda Sofística, com a mediação dos Progymnásmata, observa-se a adoção do termo écfrase, considerado correspondente da descrição latina, cujo conceito se mostra semelhante aos procedimentos aqui mencionados, uma vez que o objetivo não 
é apenas descrever, mas, sobretudo, tornar visível o objeto da descrição. As teorias que tratam do assunto são basicamente a mesma em todos os autores, ainda que de épocas distintas, conforme vimos acima.

Apesar de ser definida como processo descritivo, admite-se uma espécie de écfrase mista ou composta que reúne a ação e o tempo em que ocorre. Além disso, a própria ação já implica não se tratar de simples descrição, no sentido que atribuímos hoje ao termo, pois para haver ação é necessário apresentar progressão temporal e personagens agindo, como numa narrativa. A época, que poderia ser traduzida por tempo, já tem implícita essa ideia de eventos que ocorrem num determinado período.

A écfrase dos modos também implica certa progressão, os teóricos dos Progymnásmata são unânimes em exemplificar com o canto XVIII da Ilíada: onde se dá a fabricação das armas de Aquiles por Hefesto, o deus forja um escudo com imagens que tornam o objeto descrito quase visível e vemos as narrativas ali inseridas acontecendo. A respeito do escudo de Aquiles trataremos mais detidamente no terceiro capítulo, destinado à análise da écfrase nos textos. As personagens e os lugares apresentam, aparentemente, caráter estático, mas o propósito permanece o mesmo, a descrição detalhada desses é capaz de torná-los visíveis.

Dentre as qualidades da écfrase, temos a clareza e a enargia em primeiro lugar, características que tornam o discurso mais claro e evidente. Lembramos que a enargia já fora relacionada ao caráter imagético do discurso com alguma distinção em outras teorias.

A unidade é essencial na argumentação de ações, ao passo que os lugares, personagens, épocas e modos buscam argumentos em sua utilidade, beleza e prazer funções básicas da retórica (docere, mouere e delectare). Para Teão, as personagens também devem apresentar uma unidade, cuja descrição deve ser sequencial, dessa maneira, o processo de visualização fica mais fácil.

Teão afirma que a écfrase é composta por figuras variadas, ainda que simples e objetiva, uma vez que o objeto deve ser reconhecido com uma única palavra.

Observa-se ainda que, já nesse período, a definição da écfrase gera certa controvérsia por tratar-se de uma modalidade que também aparece em outras; no entanto, isso não a exclui como procedimento retórico; entende-se que a écfrase apresenta mais de uma função dependendo do contexto inserido, sempre com a finalidade de detalhar o discurso, porém, como exercício individual tem a função específica de evidenciar o objeto ao espectador. 
Outras modalidades descritivas são encontradas como práticas retóricas nos Progymnásmata. Hermógenes define a etopeia, nos §20-22, como a imitação do caráter de uma personagem real; a prosopopeia é a atribuição de características de uma pessoa a algo inanimado, inventando-se uma personagem irreal; por fim, a idolopeia é a atribuição de discurso aos mortos. A etopeia é classificada em várias categorias: personagens determinadas e indeterminadas; simples e dupla (diálogo); moral (predomina o caráter), emotiva (predomina a emoção) e mista. Nesse procedimento deve-se adequar o discurso às personagens e às circunstâncias. A elaboração discorre em torno dos três eixos temporais: presente, passado e futuro, considerando os fatos da categoria moral ou emotiva.

Aftônio afirma ser a etopeia de três tipos: idolopeia, prosopopeia e etopeia, em §34-36. A etopeia contém um personagem conhecido, inventando-se apenas seu caráter, a idolopeia contém um personagem conhecido que já está morto e, por fim, a prosopopeia ocorre quando se inventa a personagem e seu caráter, tratando-se de coisas inanimadas. Ele também as classifica de acordo com o critério do caráter e da emoção. A etopeia deve apresentar estilo claro, conciso, florido, simples e livre de figuras. Assim como apresentado por Hermógenes, a argumentação é dividida ao longo dos três tempos: presente, passado e futuro.

Teão sintetiza a etopeia sob o conceito da prosopopeia: a introdução de uma personagem que pronuncia discursos apropriados a ela e às circunstâncias. Para produzir o discurso é preciso antes de tudo refletir acerca do caráter daquele que profere o discurso e do seu público como, por exemplo, a idade, a ocasião, o lugar, a fortuna, os temas. Dessa maneira, os discursos são adequados ao éthos de cada um. Outras diferenças influenciam nos discursos: se é homem ou mulher (natureza), a condição de escravo ou livre (sorte), soldado ou campesino (ofício), alguém apaixonado e quem não esteja (estado anímico).

Embora a etopeia não esteja exatamente associada à écfrase, pois constitui os discursos proferidos pelas personagens, sabemos que uma das categorias da écfrase é a descrição de pessoas; a etopeia, por sua vez, é um procedimento que auxilia na construção do éthos e, portanto, indispensável à prática do discurso epidítico que faz uso dos procedimentos ecfrásticos para cumprir sua função. 


\section{Outros Retores Latinos}

Observa-se na retórica latina a presença de figuras que apresentam caráter descritivo e associam-se às funções da écfrase apresentadas nos Progymnásmata. Seguem-se alguns exemplos ${ }^{64}$ :

\section{Áquila Romano. De Figuris Sententiarum et Elocutionis.}

\section{Prosopopoiía est persona confictio.}

Prosopopeia é a invenção da personagem.

4. Ethopoiía, moralis confictio. Haec figura differt a superiore eo, quod ibi et personas fingimus, quae nusquam sunt, hic certis quibusdam [uel] personis uerba accomodate adfingimus, uel ad improbitatem earum demonstrandam uel ad dignitatem [...].

Ethopeia é a invenção dos costumes. Esta figura difere da citada acima, pois ali inventamos as personagens, que não existem em lugar algum, aqui atribuimos as palavras apropriadamente a certas personagens determinadas, para demonstrar sua improbidade ou dignidade [...].

\section{[Júlio Rufiniano] De Schematis Dianoeas.}

13. Ethopoiía est alienorum affectum qualiumlibet dictorumque imitatio non sine reprehensione. Latine dicitur figuratio uel expressio.

Etopéia é a imitação das afecções de outros e de quaisquer ditos, não sem correção. Em latim, é chamada de figuratio ou expressio.

14. Prosopopoiía est figura sententiae, qua oratio ad alterius personae orationem imitandam retorquetur. Latine dicitur deformatio uel effiguratio.

Prosopopeia é a figura de pensamento na qual o discurso se volta para imitar o discurso de outra pessoa. Em latim, é chamada de deformatio ou effiguratio.

\footnotetext{
${ }^{64}$ Tradução nossa.
} 


\section{Schemata Dianoeas. Quae ad Rhetores Pertinent}

5. Ethopoiía, data locutio certae personae.

Etopeia é o discurso atribuído a certa personagem.

6. Prosopopoiía est alicui rei inanimatae uel defuncto adcommodata locutio.

Prosopopeia é o discurso atribuído a algo inanimado ou a alguém morto.

11. Topographía est loci descriptio, ut apud Vergilium: Est locus Italiae medius sub montibus.

Topografia é a descrição do lugar, como em Virgílo: "a região da Itália está no meio, sob os montes".

12. Topothesía est loci positio, cum describitur locus, qui non est, sed fingitur, ut: Est in secessu longo locus.

Topotesia é a situação do lugar quando ele é descrito, mas não existe, é inventado, como: É um lugar de retiro distante.

\section{Prisciano. Praexercitamina ex Hermogene Versa.}

10. Descriptio est oratio colligens et praesentans oculis quod demonstrat. Fiunt autem descriptiones tam personarum quam rerum et temporum et status et locorum et multorum aliorum.

A descrição é o discurso que reúne e apresenta aos olhos aquilo que trata. Contudo, as descrições são feitas de personagens como de coisas, de tempo, de modo, de lugares e de muitos outros.

A etopeia e a prosopopeia apresentam a mesma definição obervada na retórica grega e, da mesma maneira, podem ser englobadas na descrição, como vimos em Prisciano que trata dos exercícios de Hermógenes. Reforça-se também a matéria variada que compõe a descrição: personagens, objetos, tempo, modo, lugares, dentre outros. 
O objetivo do procedimento descritivo é tornar presente aos aolhos do espectador a matéria tratada, tais discursos são eficientes na composição do éthos e colaboram com a finalidade do gênero epidítico, quer se queira elogiar ou vituperar, uma vez que o discurso deve reforçar as características que lhe foram atribuídas. Além do que, contribui também para conferir mais vivacidade à imagem. Tal definição da descrição lembra também a definição de enargia dada nos Schemata Dianoeas.

A topografia aparece na retórica latina como descrição específica do lugar, que Quintiliano já mencionara como uma variação da hipotipose, figura que ele afirma ser a evidência. Aqui temos a particularidade de diferenciar a descrição de lugares reais com a de lugares imaginários, a topotesia, nesse caso, como o lugar não existe, sempre estará ausente, consequentemente, a visualização da imagem dependerá do exercício imaginativo - a fantasia.

A enargia, portanto, tem a mesma finalidade da descrição de colocar a cena diante dos olhos e é variada, emprega-se com personagens, lugar e tempo, mas não implica necessariamente na descrição; contudo, nos Progymnásmata se estabelece uma relação de dependência entre enargia e écfrase, a primeira como qualidade primordial para a execução da última. Na Retórica a Herênio a descrição (IV, 51) também é entendida como o ornamento capaz de expor as ações aos olhos.

Tamanha multiplicidade de figuras e nomenclaturas atribuídas ao mesmo objetivo - colocar diante dos olhos - acarreta, atualmente, certas discussões em torno do assunto entre os teóricos, a respeito do qual trataremos no capítulo seguinte. 


\section{Sistematização dos conceitos}

A compreensão dos procedimentos retórico-poéticos voltados para o aspecto visual da arte verbal que estudamos no capítulo anterior - écfrase, descrição, enargia, evidência, fantasia - torna-se difícil ao tentarmos estabelecer criteriosa terminologia, considerando os limites e funções de cada um. As teorias propostas em torno do assunto esbarram sempre nos limites do anacronismo; portanto, procuramos nos ater às teorias antigas que, por sua vez, geram certa confusão em razão da multiplicidade de termos para o mesmo conceito. Além disso, teóricos de épocas distintas compuseram o conceito que hoje fazemos de tais recursos, cada época com seu pensamento e finalidades distintas, modificando de alguma maneira aspectos da teoria.

Dedicamo-nos, na primeira parte de nosso trabalho, a detalhar as teorias concernentes ao assunto; daqui em diante nossa proposta é investigá-las, a fim de propor um quadro teórico que englobe as diversas faces dos processos que permitem aproximar o discurso verbal do visual.

Alguns estudos em torno da evidência ou da écfrase concentram-se, sobretudo, no efeito desses procedimentos; embora as questões em torno da terminologia sejam levantadas, elas não constituem a preocupação principal dos pesquisadores. Por essa razão, a problemática acerca não apenas das definições, como também da nomenclatura, que requer tanta atenção, geralmente, acaba por ser analisada superficialmente.

Em alguns casos, a maneira como um dos conceitos é apresentado demonstra a relação entre eles, mas não estabelece bem seus limites; por exemplo, a evidência chega até mesmo a parecer quase como sinônimo da écfrase ${ }^{65}$; contudo, a primeira é, retoricamente, a figura que dispõe diante dos olhos, ao passo que a écfrase é propriamente o processo utilizado para produzir tal resultado.

\footnotetext{
${ }^{65}$ Cf. PINEDA, V. "La invención de la écfrasis". In: VV. AA., Homenaje a la Profesora Carmen Pérez Romero. Universidad de Extremadura. Facultad de Filosofía y Letras. 2000. pp. 249-60. Cito algumas referências que abordam o tema da terminologia, embora a maior parte dos artigos concernentes ao assunto levante, ainda que rapidamente, essa questão: BEAJOUR, M. "Some paradoxes of description". In: Yale French Studies. 1981. №61, pp.27-59; DUBEL, S. "Ekphrasis et enargeia: la description antique comme parcours”. In: LEVY, C. \& PERNOT, L. Dire L'Évidence. Paris: L’Harmattan. 1997, pp.249-64; CASSIN, B. "Procedures Sophistiques pour construire l'évidence". In: LEVY, C. \& PERNOT, L. Dire L'Évidence. Paris: L'Harmattan. 1997, pp.15-29; BENEDIKSTON, D. T. "Phantasia. Plato and Aristotle, Cicero and other Romans, Dio Chrysostom, and Philostratus". In: Literature and the Visual Arts in Ancient Greece and Rome. Universsity of Oklahoma Press. 2000, pp.162-188.WEBB, R. Ekphrasis, Imagination and Persuasion in Ancient Rhetorical Theory and Practice. Surrey: Ashgate. 2009.
} 
A fantasia é também confundida com a enargia, mas partindo da primeira teorização acerca da fantasia, de Aristóteles, sabemos tratar-se de um mecanismo que se processa no indivíduo por meio de vários elementos para produção de imagens. A fantasia pode explicar como se processa a enargia; no entanto, devemos lembrar que a ela faz parte de uma teoria filosófica que não pretende explicar os recursos retóricos ou poéticos. Mesmo assim, é um conceito que não pode ser ignorado, uma vez que trata da característica fundamental para a compreensão dos demais procedimentos: a visualização de uma imagem ausente.

A pesquisa efetuada na primeira parte desse estudo é uma tentativa de expor as teorias antigas concernentes aos procedimentos estudados, acreditamos que dessa maneira o risco de cometermos incoerências seja menor. Ainda assim, sistematizar os conceitos pode gerar algumas discussões, até mesmo porque o modo como hoje entendemos os conceitos é bem diferente; a descrição, por exemplo, é atualmente tida como um texto estático, mas o que observamos por meio dos antigos é que está longe de sê-lo.

É possível que haja outros procedimentos relacionados à visualização do discurso além dos estudados aqui, visto que nos propusemos a relacionar apenas os conceitos que estejam associados à écfrase. Não esgotamos o assunto, tendo em vista que a intersecção teórica entre arte verbal e não-verbal apresenta abundante repertório em tratados que concernem à filosofia, à poética e à retórica - tratamos aqui a respeito de uma parcela diminuta, porém significativa, desse todo.

\section{II.1. ÉCFRASE/ DESCRIÇÃo}

Considerando o quadro em que a écfrase se insere, teríamos a teorização a partir da Segunda Sofística, por essa razão o conteúdo dos Progymnásmata é peça central dessa pesquisa.

A classificação da écfrase estabelecida em tais exercícios retóricos demonstra sua classificação de acordo com o "objeto" de descrição.

Alguns exemplos são clássicos, tal como o escudo de Aquiles. Datam da Segunda Sofística algumas obras que empregam a écfrase, cujo caráter remete ao gênero de descrição de obras de arte, dentre os quais se destacam: Eikones de Filóstrato; as Ekphraseis de Calístrato; "Zêuxis ou Antíoco" de Luciano de Samósata; há também romances sofísticos como As Aventuras de Leucipa e Clitofonte, de Aquiles Tácio, e 
Dafnis e Cloe, de Longo, em que se opera a écfrase. Hansen ${ }^{66}$ discute a definição da écfrase como gênero:

\begin{abstract}
No século XX, principalmente, historiadores da arte passaram a usar o termo restrito à acepção de "descrição de obra de arte". Esse uso praticamente apagou o significado técnico de ekphrasis como "exposição" ou "descrição" em geral. Assim, generalizando à acepção particular, vários autores afirmaram que o topos "clássico" da ekphrasis é o escudo de Aquiles nos versos 483-608 do canto 18 da Ilíada. Trata-se efetivamente de "exposição" de aspectos, mas há duas objeções consideráveis à sua classificação como ekphrasis no sentido generalizado pelos historiadores da arte. A primeira é histórica e critica o anacronismo, pois o poema de Homero é muito anterior à prática do gênero e as retóricas que o doutrinam. A segunda é poética e, como fez Lessing no século XVIII, propõe que não se pode isolar a descrição do escudo da ação épica do poema. (pp.87)
\end{abstract}

A nomeação tardia do mecanismo apenas serve como confirmação de um processo que já vinha sendo utilizado na poesia e na retórica. No entanto, Hansen mostra que tratar a écfrase simplesmente como gênero voltado às obras de arte seria incoerente quando relacionado ao escudo de Aquiles, pois não se trata da descrição isolada de um objeto.

Nicolau de Mira $^{67}$ (séc. III-IV), §69, também é um conhecido autor de Progymnásmata que coloca a pintura e a escultura entre os objetos da écfrase, fundamentando, portanto, a écfrase de obra de arte; mas o mesmo autor reconhece outros tipos que tradicionalmente se enquadram na classificação apontada durante a Segunda Sofística.

Considerar os Eikones como representante da écfrase é lugar-comum, o que se torna discutível quando as demais possibilidades da écfrase são deixadas de lado. Caso se tratasse simplesmente de descrição de obras, não haveria a diversidade apresentada pelos retores e que se comprova por uma longa tradição poética, uma vez que a écfrase é frequente se levarmos em conta todos os tipos de descrição.

Afirmar que o escudo de Aquiles não é écfrase por não exisitir uma teoria concernente a esse recurso na época, nos faria concluir que nada pode ser afirmado a respeito dos poemas homéricos, considerando-se que os estudos da póética e também da retórica sucedem Homero. Devemos lembrar que os exercícios de retórica nos trazem

\footnotetext{
${ }^{66}$ HANSEN, J. A. “As categorias epidíticas da ekphrasis". In: Revista USP. 2006 n71, pp.85-105.

${ }^{67}$ Não encontramos a tradução dos Progymnásmata desse autor, cuja consulta ficou restrita à tradução da passagem da "écfrase" no livro citado na nota 57 - Cf. pp.202-3.
} 
como exemplo de écfrase de modo os preparativos do livro XVIII da Ilíada, no qual está presente a célebre passagem da produção do escudo de Aquiles. Portanto, a écfrase está presente já nos poemas homéricos, mas como método de exposição dos elementos visuais; constitui um topos da écfrase no sentido mais abrangente - não como gênero pois é consenso entre os teóricos que o escudo de Aquiles seja a primeira ocorrência.

Na tradição latina, a descrição é tida como um discurso amplificador que detalha para expor diante dos olhos, portanto, não há dúvida quanto à correspondência entre écfrase e descrição.

Na retórica helenística, como já afirmamos, o termo ékphrasis era amplo, visto que não se limitava aos casos específicos de descrição de objetos ou obras, englobava a descrição de qualquer coisa, animada ou inanimada. A descrição era entendida, portanto, como um dispositivo que detalhava o seu objeto de tal maneira que pudesse ser claro o bastante para a "visualização" do mesmo.

Já vimos que a descrição não é restrita aos objetos estáticos, mas também serve para relatar processos, logo, implicam movimentação. Conforme Teão e Aftônio, esse gênero ecfrástico é "misto" ou "composto" e as écfrases integram-se à ação dos poemas, narrando fatos.

A teoria em torno dos procedimentos descritivos consagra-se pelo uso dos mesmos, tanto na teoria retórica como na poética.

Façamos um exercício imaginativo para pensar como seriam as narrativas épicas sem a apresentação dos seus heróis: não saberíamos sua ascendência, sua aparência, o grau de sua força e tampouco como seria o combate decisivo sem o detalhamento das condições em que ocorre (Por quê? Com quem? Onde? Com que armas?). Como demonstrar a beleza de um objeto ou a grandiosidade de uma frota de navios sem a enumeração de suas particularidades? Pode-se afirmar que algo é belo, mas sua beleza só será transmitida ao leitor se puder imaginar os aspectos que a compõem. Como elogiar a figura de um político sem justificar por meio de sua caracterização moral e de seus feitos? Como um defensor poderia persuadir seu público da inocência do réu sem demonstrar todos os detalhes dos fatos que envolvem o acontecimento?

Ainda que todas as situações exijam a narração dos fatos, a descrição torna-se indispensável na estrutura do texto. Obviamente a descrição constitui, muitas vezes, um recurso "genérico", no entanto, em alguns casos, acaba adquirindo autonomia. É o que 
afirma Beaujour em "Some paradoxes of description" discurso epidítico - a descrição estende-se para cumprir sua função ao máximo, pois tanto para louvar como para vituperar, é um método necessário, dessa forma, a descrição foi adquirindo certa autonomia estética sob a denominação de écfrase.

Philippe Hamon ${ }^{69}$ fala da dificuldade em definir a descrição, pois ela não tem um estatuto semântico - não é, por exemplo, um tropo e não pode ser definido a partir do mesmo paradigma; sabe-se que a descrição é um dos inúmeros meios da amplificação. Essa dificuldade também ocorre na conceituação dos demais procedimentos aqui investigados ${ }^{70}$.

Na retórica, o objetivo da descrição é mais dispor o objeto diante do espectador do que propriamente explicá-lo, com a finalidade de representar além das características sensíveis do objeto também as características inteligíveis ${ }^{71}$. A distinção entre narração e descrição como temos hoje não se observava na retórica antiga, por essa razão, a descrição, por vezes, rompia com o aspecto estático para contribuir com o efeito de vividez, tais como os processos de produção das imagens ou mesmo a menção aos fatos implícitos na cena. $\mathrm{O}$ dispositivo ecfrástico, portanto, remete ao discurso periegético, que guia o espectador ao redor da cena descrita, explorando ao máximo as possibilidades que a imagem encerra.

Os termos que nos remetem ao conceito da écfrase são variáveis, portanto, é possível encontrarmos menção ao processo descritivo ainda que não apareça exatamente "ékphrasis" ou o verbo "ekphrazo".

Comumente, em contextos ecfrásticos, a expressão "enárgeia" aparece para tratar do aspecto de vivacidade dos textos. Dentre as acepções fornecidas no dicionário de Liddell \& $\mathrm{Scott}^{72}$, a enargia significa clareza (seu primeiro significado), uma percepção clara e nítida ou mesmo uma descrição vívida no âmbito retórico. Segundo $\operatorname{Cassin}^{73}$, a écfrase é a figura retórica por excelência da enargia.

\footnotetext{
${ }^{68}$ Cf. nota 65.

69 "Rhetorical status of the descriptive". In: Yale French Studies. 1981. N61, pp. 1-26.

${ }^{70}$ Em nota, Dubel (Cf.nota 65) reúne três acepções atribuídas à enargia por Quintiliano, as quais já expusemos: na discussão a respeito das paixões (VI,II,32) a enargia é associada à fantasia; trata-se de uma virtude da oração (VIII, III,61-71); é ainda encontrada como uma virtude do discurso, portanto, um ornato (IX,2,40-3).

${ }^{71}$ WEBB, Ruth. "The aesthetics of sacred space: narrative, metaphor, and motion in 'ekphraseis' of church buildings". In: Dumbarton Oaks Papers. 1999. Vol 53, pp. 59-74.

${ }^{72}$ LIDDELL, H. G. \& SCOTT, R. A Greek English Lexicon. Oxford: Clarendon Press. 1996. Adotamos aqui esse dicionário para todas as consultas aos vocábulos gregos citados adiante.

${ }^{73}$ Op. cit. na nota $65-$ Cf. pp. 22 .
} 
Alguns verbos remetem ao mecanismo descritivo. O verbo exergéomai tem dentre seus significados: expor; relatar integralmente; apresentar. Outro verbo nos remete à definição de écfrase dada por Teão de logos periegematikòs - periegéomai quer dizer: explicar, decrever (em linhas gerais); periegesis pode ser "condução ao redor e explicação; descrição geográfica". A écfrase apresenta esse caráter periegético, sobretudo ao descrever objetos (reais ou não), uma vez que a descrição detalhada procura fornecer todos os elementos para a presentificação da imagem, os olhos podem ver ao redor de toda a imagem.

Temos ainda outros verbos que podem ser associados à écfrase: syggrápho significa, dentre outras coisas, "descrever" e também "representar em pintura"; diagrapho - nas acepções que nos interessam pode significar "delinear ou descrever uma pessoa"; diatypóo quer dizer "formar, ser gravado, imaginar, representar".

De acordo com Hamon ${ }^{74}$, os estudiosos se satisfazem com a classificação da descrição de acordo com o objeto referente: cronografia - descrição de tempo;

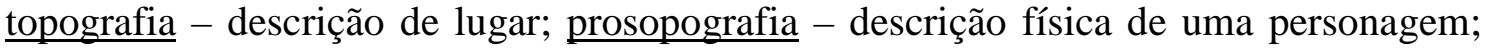
etopeia - descrição moral de uma personagem; prosopopeia - descrição de um ser imaginário ou alegórico; retrato - descrição física e moral; paralelo - combinação de duas descrições, por meio de semelhança ou antítese, de objetos ou personagens; hipotipose - descrição vivaz de ações, paixões, eventos físicos ou morais.

Semelhante tipologia é apresentada por Hansen ${ }^{75}$ : pragmatografia - descrição de coisas; prosopografia - de pessoas; etopeia - de paixões e caracteres; topografia - de lugares reais; topotésia - de lugares imaginários; chronografia - de tempo.

Observamos nos Progymnásmata de Teão uma tipologia bem próxima das apresentadas acima. É evidente que a écfrase engloba inúmeras categorias em relação ao objeto descrito, isso, porém, não a limita como processo voltado exclusivamente à descrição apartada do contexto em que está inserida. Embora possa constituir-se como um gênero de descrição, isso não restringe sua atuação apenas nesse campo.

A écfrase mista ou composta, como vimos, mescla ação e tempo, na realidade, temos aqui uma écfrase narrativa - exatamente como a narração é entendida atualmente.

A etopeia e a prosopopeia são conceitos correspondentes a procedimentos descritivos presentes nos Progymnásmata, os quais se convencionaram entre as modalidades ecfrásticas. Ambas estão presentes também na retórica latina, cujos

\footnotetext{
${ }^{74}$ Op. cit. na nota $69-$ Cf. pp.3.

${ }^{75}$ Cf. nota 66.
} 
preceitos corroboram a definição da Segunda Sofística e se enquadram entre as figuras de pensamento.

A etopeia serve aos propósitos do gênero demonstrativo, pois quando se quer elogiar ou vituperar é necessário enumerar as qualidades ou defeitos do indivíduo, quer sejam características físicas ou morais. Logicamente, aproveita-se a descrição como forma amplificadora, pois o orador ou o poeta tratará de destacar aquilo que convier ao objetivo de seu texto.

A prosopopeia se estabeleceu como figura de linguagem bastante difundida atualmente, denominando a atribuição de características humanas a seres inanimados. Na Retórica de Aristóteles, embora não haja referência à prosopopeia, em sua exposição acerca da metáfora, ele fornece vários exemplos de metáforas que "trazem diante dos olhos" - objetivo da metáfora com maior prestígio - e, para isso, a representação da ação (energeia) é muito eficiente, pode inclusive tratar-se de seres inanimados que fazem a ação. Também sobre a metáfora, Quintiliano reafirma a possibilidade de animar seres inanimados, pois isso torna o efeito metafórico mais sublime.

Como procedimentos da retórica antiga para imitar personagens, vivos ou mortos, animados ou não, atribuem-se-lhes características e discursos adequados a cada um - a etopeia se concentra no aspecto moral, não é mera descrição física, que é o proposto na prosopografia. Observa-se ainda que analogamente a estas existe a idolopeia, associada a personagens já mortos e cuja descrição e atribuição de discurso torna-os animados novamente .

A hipotipose nos é apresentada por Quintiliano como a figura da exposição detalhada que expõe diante dos olhos que, por sua vez, se associa à etopeia no que concerne aos feitos da personagem retratada.

Topografia é outro mecanismo descritivo muito comum, não é apenas mencionada nos exercícios de retórica, como também está entre os tipos de descrição vívida em Quintiliano, cujo conceito se relaciona com a hipotipose. Entre os latinistas, observamos a diferenciação da descrição de lugares reais e imaginários - esta última consiste na topotésia. Apesar da diferença quanto ao referente, o processo permanece o mesmo.

A cronografia aparece na retórica grega e latina, faz parte, portanto, do inventário ecfrástico. Embora possa parecer estranho à ideia que hoje fazemos da descrição, o detalhamento de determinadas épocas nos poemas antigos é muito frequente, pois se incluem nesse tipo as festividades. 
A écfrase reflete, portanto, uma série de processos já existentes que não estavam sob essa alcunha, mas que faziam parte de um mesmo grupo. Como sugere Dubel ${ }^{76}$, parece ocorrer uma construção progressiva da autonomia da descrição, adquirida com a écfrase. A princípio, a descrição é um efeito do texto, mas com a écfrase passa a integrá-lo.

É interessante observar que apesar de apresentar uma tipologia, suas espécies, por assim dizer, aparecem na tradição retórica com autonomia de figura - o que nos faria questionar se a écfrase pode ter estatuto de figura, uma vez que é composta por várias delas.

Na Retórica a Herênio, além da descrição, a demonstração corresponde igualmente ao conceito da écfrase que narra ações com a finalidade de produzir a enargia.

A definição atribuída à écfrase ou descrição no Manual de Retórica Literaria de Lausberg $^{77}, \S 1133$, é "a descrição detalhada de uma pessoa ou objeto, cujo objetivo é a enargia”.

Nicolau de Mira, §70, aconselha o emprego da écfrase nos três gêneros retóricos: no deliberativo torna o discurso mais persuasivo; no judiciário, a amplificação que ela produz é necessária; no epidítico, é suficiente para agradar ao público.

Integrada à ação do discurso ou de caráter digressivo, a écfrase ou descrição cumpre a função de maravilhar o espectador diante do quadro que se apresenta. Em textos de cunho poético, o deleite costuma sobrepor-se às demais funções presentes; discursos do gênero judiciário, por sua vez, precisam comover, função que é bem desempenhada pelo caráter amplificativo da écfrase, pois os aspectos patéticos são ressaltados. No entanto, conforme veremos no próximo capítulo, o propósito da écfrase é variável, determinado não só pelo gênero poético ou retórico, mas também por elementos próprios de cada texto.

\section{II.2. ENARGIA/ EVIDÊNCIA}

A enargia é traduzida por evidência na retórica latina, cujo adjetivo correspondente é enargês, termo que aparece frequentemente em tratados quando se menciona questões concernentes à vivacidade com que se expõem os fatos narrados. A

\footnotetext{
${ }^{76}$ Cf. nota 65.

${ }^{77}$ LAUSBERG, H. Manual de Retórica Literaria. Tradução de R. M. Rosado Fernandes. Lisboa: Fund. Caloust Gulbenkian, 1966, vol.2.
} 
definição de écfrase nos Progymnásmata é a de um logos enargôs, além disso, a enargia está entre as duas virtudes da écfrase, juntamente com a saphéneia (clareza, nitidez).

O vocábulo euidentia é assim designado no dicionário de Saraiva $^{78}$ : clareza, evidência; hypotypose (figura retórica). Assim como ocorre com a enargia, há em latim um adjetivo relacionado à evidência: euidens - visível, claro, patente, manifesto, evidente. Outra nomenclatura nos é dada por Quintiliano, a illustratio: ação de esclarecer; descrição viva e enérgica, hypotypose. Dentre as acepções para perspicuitas, mencionada por Cícero, temos também "evidência".

O vocábulo grego enárgeia quer dizer também "clareza, nitidez, vivacidade e percepção (visão) clara”. Hypotýposis tem entre suas acepções "figura retórica por meio da qual um assunto era vividamente desenhado em palavras". Outro termo mencionado por Quintiliano e também nos exercícios de retórica é a diatýposis - figura completa e perfeita; descrição vívida.

$\operatorname{Cassin}^{79}$ comenta a pluralidade de termos referentes ao mesmo conceito, mas afirma que na língua latina a variação é menor, pois a enargia grega, como se observa em Cícero, corresponde canonicamente à evidência ou perspicuitas latina. Nos textos gregos, outros adjetivos além de enargês são encontrados em contextos da enargia, tais como: dêlos, phaneros, saphês, emphanês.

Conforme demonstrado no primeiro capítulo, a conceituação da evidência também aparece em textos latinos sem que o próprio termo seja diretamente mencionado - o que nos faz discordar em parte da afirmação de Cassin, visto que julga a equivalência da evidência (considerando sua língua nativa - o francês) em latim diretamente com "euidentia", sem que haja muitas variações a partir das quais alguma confusão possa ser gerada na conceituação.

Os tratados de Cícero provam que, muitas vezes, ao tratar do caráter imagético de um discurso verbal, o conceito da evidência permeia a teoria implicitamente. Mesmo quando aparece em sua Academica, a evidência insere-se na discussão filosófica que não indica propriamente seu caráter retórico ou poético. Apenas a partir de Quintiliano temos a sistematização como mecanismo retórico e, ainda assim, não figura sob uma única denominação.

\footnotetext{
${ }^{78}$ SARAIVA, F. R. dos Santos. Novíssimo Dicionário Latino-Português. 1927. Adotamos aqui esse dicionário para todas as consultas aos vocábulos latinos citados durante a pesquisa.

${ }^{79}$ Cf. nota 65.
} 
É fato que o mesmo ocorre com a enargia, mas com a particularidade de tratar-se de um vocábulo já com um histórico mais antigo, muito citado, ainda que sob a forma adjetiva. Nos diálogos de Platão e também nos tratados de Aristóteles já se observa a ocorrência do termo em suas variações. Na Poética de Aristóteles, 1455a, ele menciona "enargestata" para tratar daquilo que pode ser visto como se estivesse presente.

Na Retórica, ao tratar da metáfora, o termo "energeia" gera dúvida se não seria na verdade "enárgeia". A respeito disso, $\mathrm{Webb}^{80}$ afirma que há mais do que mera semelhança morfológica: o efeito provocado pela enargia atua sobre o estado emocional do ouvinte; segundo Nicolau, em seus Progymnásmata, é a enargia que distingue a écfrase da narração pura e simples e procura transformar o público ouvinte em espectador - funcionaria, portanto, como a energeia, cuja definição é "atividade, ação", pois age sobre o público.

Webb afirma, contudo, que a crítica moderna considera tais definições um tanto ingênuas, pois ignoram as noções fundamentais da linguagem. A retórica não seria suficiente para resolver questões epistemológicas concernentes à enargia, uma vez que tal assunto conerne à filosofia. A enargia precisa, portanto, ser analisada também em chave filosófica - é o que propomos nessa pesquisa desde o princípio, quando expusemos, além dos preceitos retóricos e poéticos, as teorias filosóficas que contribuem para a compreensão da enargia e dos demais conceitos aqui estudados.

No entanto, uma proposição de Cassin nos permite inferir um significado mais próprio à enargia do que aos demais adjetivos que lhe são semelhantes. Considerando o emprego do termo nos poemas homéricos - situações de sonhos, devaneios ou quando as personagens veem divindades - "enargês" não quer dizer o testemunho imediato da visão, mas a presentificação do invisível, que é tornado visível. Vejamos então alguns exemplos extraídos de Homero ${ }^{81}$ :

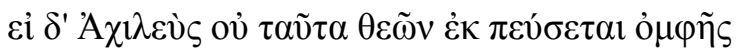

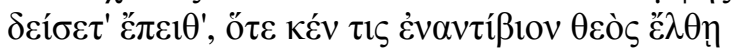

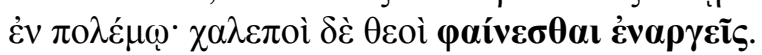

Se pela voz de um dos deuses não for informado ora Aquiles,/ há de recear quando alguma deidade o atacar nos combates,/ é tremenda a aparência dos deuses eternos. (Ilíada, XX, 129-31)

\footnotetext{
${ }^{80}$ WEBB, R. "Mémoire et imagination: les limites del'enargeia dans la théorie rhétorique grecque". In: LEVY, C. \& PERNOT, L. Dire L'Évidence. Paris: L'Harmattan. 1997, pp.229-39.

${ }^{81}$ Para todas as citações dos poemas homéricos adotamos a tradução de C. A. Nunes. Rio de Janeiro: Ediouro. 2001.
} 


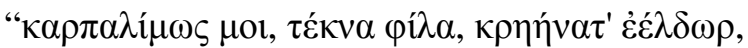

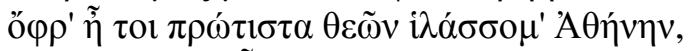

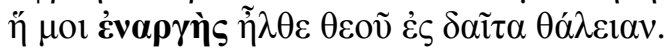

Sem mais delongas, meus filhos queridos, cumpri-me o desejo,/ para que obsecre, primeiro que aos outros, o auxílio de Atena,/ que no banquete opulento do deus claramente foi vista. [...] (Odisseia, III, 418-20)

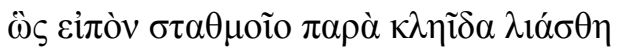

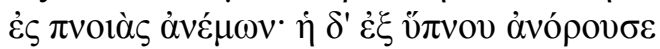

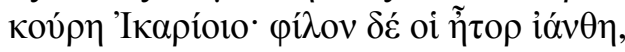

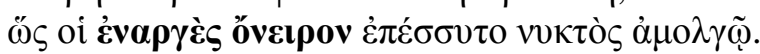

Tendo isso dito, esvaeceu-se o fantasma, qual sopro do vento,/ pelo ferrolho da porta. A de Ícaro nascida desperta/ logo do sono. Seu peito outra vez de alegria se aquece,/ por lhe ter vindo no escuro da noite visão tão luzente. (Od., IV, 838-41)

A autora, ainda no mesmo texto, prossegue afirmando que os demais adjetivos apresentam acepção um tanto diferenciada: dêlon - é evidente porque mostra, exibe; phaneron, emphanes - aparece, brilha, porque é esclarecido (iluminado); phainô etimologicamente é uma das formas ligadas ao realce, é evidente porque é enunciado, exposto.

Podemos dizer que o efeito da enargia está sempre presente no efeito de inúmeros tropos ou figuras, tais como a metáfora, o símile, a hipérbole, a prosopopeia, a alegoria, entre outros - fato claro na explanação acerca da metáfora e também da amplificação. Os processos adotados para se obter a enargia ou evidência são essencialmente amplificativos, pois contribui para a exposição perspícua do assunto, além de ser mais eficiente na comoção. A enargia é capaz de comover o público, caso contrário, a visualização do discurso não ocorreria, uma vez que ela depende de certa atividade anímica operada no indivíduo.

O resultado da enargia, portanto, requer mecanismos amplificadores, dentre os quais se encontra a écfrase ou descrição.

Os métodos da amplificação contribuem não apenas para a comoção e o deleite (próprio do gênero demonstrativo), mas também para reforçar a credibilidade, pois permite ilustrar o discurso verbal - aquilo que se torna "visível" comove mais intensamente e opera em favor da argumentação. A amplificação, portanto, é um 
procedimento que funciona em todos os gêneros retóricos, uma vez que é capaz de cumprir as funções correspondentes.

A metáfora, além de ser um tropo reputado, possibilita trazer o discurso verbal aos olhos, representando uma ação (energia), permitindo até mesmo a apresentação das propriedades ausentes - está patente aqui o resultado da enargia, pois ocorre a presentificação, que requer o exercício da fantasia. Desempenha, portanto, a função de comover, que é ressaltada por Quintiliano ao aludir a sua capacidade de pôr diante dos olhos, tal qual Aristóteles, além de permitir inferir outras coisas que não foram expostas a respeito do objeto metaforizado. No entanto, a função ressaltada por Aristóteles é a de ensinar, se usada apropriadamente, a metáfora produz conhecimento e ao mesmo tempo deleita, pois aprender é agradável. Para Cícero, a metáfora torna as coisas mais claras e por isso deleita, além de ter muita força para comover, pois afeta diretamente a visão - o sentido mais sensível - mas só se realmente houver correspondência do termo transladado em relação ao original.

Comprova-se, portanto, que na teoria concernente à metáfora, muitos dos princípios que norteiam a enargia e, consequentemente, a écfrase, já estavam presentes na prática retórica e poética.

O símile - figura semelhante à metáfora - funciona simultaneamente como ornato e argumento quando clarifica o conteúdo veiculado. Logo, conforme a proposição de Martins ${ }^{82}$, poderíamos classificar o símile em poético e oratório; dadas as características da enargia e da écfrase é coerente afirmar que tais recursos também operam nos dois âmbitos. Em razão da intersecção entre as duas práticas, a teoria disposta nos tratados retóricos serve para sua aplicação poética, como procuramos ressaltar desde o começo - propomos então que haja de um lado uma écfrase/ descrição retórica produtora da enargia/ evidência e, de outro, uma écfrase/ descrição poética, cujo efeito é o mesmo. Dessa forma, desconsideraríamos as discussões em torno do conceito que ora é gênero, ora é figura, levando em conta o contexto de produção e sua finalidade.

Observa-se a presença de uma tipologia para a enargia no tratado sobre figuras de pensamento em Quae ad Rhetores Pertinent, segundo a qual poderia ocorrer de três modos: com personagem, lugar e tempo. A conexão com a classificação da écfrase nos parece inevitável, contudo, devemos lembrar que a enargia não depende exclusivamente

\footnotetext{
${ }^{82}$ Cf. nota 32.
} 
daquela e, por sua vez, tem estatuto de figura nos tratados latinos, o que nos remonta ao fato de poder ser produzida por outros meios.

Lembremos ainda que Quintiliano atribui à evidência outros termos como illustratio, repraesentatio, hypotýposis e diatýposis - as duas últimas numa categoria em que há transferência temporal, pois os fatos expostos podem pertencer ao passado, ao presente e ao futuro. A terminologia, portanto, gera certo conflito já que estabelecemos anteriormente a relação da hipotipose e da diatipose com a écfrase, visto que suas ocorrências nos Progymnásmata querem dizer a descrição vívida e, a evidência, por sua vez, seria o resultado de tais procedimentos.

Hélio Teão fala da diatipose como descrição vívida quando discorre acerca do lugar-comum, este é uma composição ampificadora de uma ação reconhecida, tal como um delito ou um ato nobre, mas distingue-se do elogio ou do vitupério porque esses tratam de personagens específicos e apresentam provas, ao passo que o lugar-comum trata unicamente de feitos e sem apresentação de provas - ele próprio se constitui uma fonte de argumentos. A diatipose finaliza o lugar-comum ao expor o delito como se se realizasse no presente, cujo efeito, portanto, é de visualização. O verbo aqui adotado é o diagrapho, que já vimos corresponder à écfrase.

A écfrase é semelhante ao lugar-comum porque ambos tratam de questões comuns e gerais, no entanto, diferenciam-se pelo fato de que o lugar-comum se refere a aspectos que obedecem a uma intenção prévia; ao passo que a écfrase quase sempre se refere a seres inanimados e desprovidos de vontade, além disso, a écfrase é uma simples exposição do objeto, enquanto o lugar-comum pode ser acrescido de nossa opinião essa é a diferenciação feita por Teão.

Embora bastante lógico na diferenciação entre lugar-comum e écfrase, a limitação desta a objetos inanimados é incoerente se a aplicamos às demais espécies já mencionadas, pois pessoas podem ser descritas, bem como suas ações.

Se recordarmos a anedota de Simônides contada por Cícero no De Oratore, conseguimos também estabelecer essa mesma relação entre a enargia e o lugar-comum: inserimos os objetos em lugares para que através da visão consigamos nos lembrar deles - o efeito de visualização é a enargia, expondo as imagens que são definidas pelas convenções e valores culturais; quando produzida pela écfrase tem finalidade distinta, pois não mais se destina à memorização, mas ao exercício da imaginação. 
A écfrase ainda se distancia do lugar-comum como método amplificador, pois a função deste último deve ser cumprida por meio de imagens pontuais, ao passo que a écfrase acumula detalhes para produzir mais do que uma única imagem.

É inegável a relação entre écfrase e enargia, visto que mesmo tentando discorrer acerca da evidência, acabamos retomando questões concernentes à écfrase.

Não temos a classificação da evidência nos teóricos antigos, apesar de observarmos exemplos em Quintiliano que apresentam situações diferentes, todas com o objetivo de intensificar a comoção.

Autores modernos, no entanto, propõem algumas tipologias. Cassin propõe que haja dois campos de aplicação da evidência: a filosofia e a retórica. A evidência filosófica está relacionada ao que é verdadeiro, é, por sua vez, produzida pelo sentido que lhe é particular - a visão - e parte das coisas para as palavras; enquanto a retórica constrói uma relação diversa, pois os ouvidos nos servem de olhos, vai da palavra para as coisas, produzindo uma ficção. Haveria ainda um terceiro tipo originado da evidência retórica, trata-se da literária (sigo o nome adotado pela autora, desconsiderando o anacronismo do termo) - parte da palavra para a palavra, como as écfrases de Filóstrato.

Brisson $^{83}$ divide a evidência em intuitiva e discursiva se inserida apenas no âmbito filosófico: a primeira resulta da percepção imediata de uma realidade, portanto, sensível; a discursiva é a consequência de uma demonstração, não é então sensível.

\section{II.3. FANTASIA}

Entendemos que tanto a écfrase/ descrição como a enargia/ evidência pertencem às práticas retórico-poéticas, mas os resultados obtidos por meio delas dependem da atividade que se processa no indivíduo. Por essa razão é necessário recorrermos a algumas doutrinas filosóficas para compreendê-la, as quais foram discutidas no primeiro capítulo.

O conceito que se encaixa perfeitamente no efeito da enargia é a fantasia. A phantasía origina-se de pháos - "luz", remetendo ao caráter visual do processo. A exemplo do que ocorre com a enargia, encontramos outros vocábulos que nos remetem ao processo da fantasia. O adjetivo phantastikós refere-se aquilo que é capaz de produzir a aparência de algo, a arte de produzir aparências; phántasma corresponde também à “aparição, visão, fantasma”.

${ }^{83}$ BRISSON, L. "L'intelligible comme source ultime d'évidence chez Platon”. In: LEVY, C. \& PERNOT, L. Dire L'Évidence. Paris: L'Harmattan. 1997, pp.95-111. 
A fantasia é o termo grego para a presentificação visual de imagens ausentes, mas a exemplo do que ocorre com os demais procedimentos aqui estudados, há também uma denominação latina. Cícero apresenta o equivalente uisum, Quintiliano, uisio. Os dois termos apresentam acepções semelhantes: uisum - visão, imagem, sonho; uisio vista, aparição, visão, sonho.

A fantasia na doutrina platônica permeia seus diálogos, trazida sempre como o simulacro de algo real. A partir das imagens obtidas pela percepção, as impressões da percepção são recebidas na alma e se produzem os simulacros.

Aristóteles reafirma a relação entre percepção e fantasia, pois a segunda não ocorre sem a primeira. O pensamento tem papel importante para ele, assim como se observa em Platão, e ele destaca ainda o papel da memória no processo imaginativo, uma vez que a visualização do objeto ausente requer que o indivíduo recorrra ao seu repertório de imagens.

A atividade imaginativa como manifestação da memória é corroborada pela teoria da mnemotécnica apresentada por Cícero no De Oratore e ainda reafirmada em Academica, pois a memória preserva a afecção do sentido e a fantasia permite produzir uma representação (fantasma) do objeto que produziu tal afecção.

$\mathrm{Na}$ tentativa de encontrar uma definição para a fantasia, Aristóteles nos mostra que muitos elementos compõem o exercício de imaginação: a percepção, a opinião, o conhecimento, o pensamento, a razão e a memória. Reduzi-la, contudo, à fórmula da soma de tais elementos não seria suficiente. $\mathrm{O}$ conhecimento que temos das imagens depende da percepção dos objetos sensíveis, no entanto, podemos visualizar algo que não esteja presente, o que significa que a percepção não ocorre de fato, mas os demais elementos permitem "reproduzir" diante dos olhos a imagem que fazemos do objeto. Por essa razão, as fantasias também se manifestam nos sonhos.

Como provoca comoção ao produzir a imagem - pois não só o simulacro do objeto vem à mente, mas também certa emoção proporcionada pela ideia do que se representa - dessa maneira, a fantasia constitui-se como certo movimento na alma. $\mathrm{O}$ caráter patético, portanto, está presente nessa operação que, quando associado aos mecanismos retóricos, cumpre a função de comover.

Encontramos o termo "fantasia" no De Anima significando não só a imaginação, como também a própria imagem produzida. Ocorre que a imagem propriamente também é chamada de "fantasma" ao longo do tratado, isso nos remete às considerações feitas a respeito dos conceitos já discutidos: a compreensão do conceito não restringe sua 
terminologia - de acordo com Longino, por exemplo, a fantasia pode ser chamada de idolopeia - além disso, o De Anima é um tratado filosófico que procura antes discutir o assunto do que propriamente defini-lo.

O termo "fantasma" em Aristóteles aparece denotando as imagens mentais, para os estóicos, a ideia de fantasma é diversa da fantasia, pois seria um objeto ilusório, sem base real, geradora do fantástico.

Cícero apresenta uma longa discussão acerca não só da fantasia em Academica, mas também de outras questões divergentes entre diversas doutrinas filosóficas; nesse diálogo é possível identificar o embate entre os acadêmicos, os estóicos e os epicuristas. A busca pelo critério da verdade é a incansável pergunta que a cada momento parece não ser respondida. A fantasia é um dos pontos de discussão, pois, filosoficamente, sua veracidade é discutível.

Destacamos a distinção mais emblemática entre a fantasia aristotélica e a estóica: a primeira é entendida como um processo anímico de "imaginação" (não pretendemos simplificar o conceito, mas vale a definição apenas para contrapor à estóica) e, embora associada à percepção, não seja propriamente produtora da verdade e, consequentemente, do conhecimento; a segunda, por sua vez, sob o critério da fantasia compreensiva, ou seja, a partir de um objeto verdadeiro, pode ser considerada uma representação da realidade e, portanto, produtora de conhecimento.

A alma também está presente na fantasia estóica como o local em que se processa a apreensão da representação (termo usualmente adotado para traduzir a fantasia estóica), na qual as marcas da percepção são impressas como em uma tábua de cera - mesma comparação feita por Platão. Crisipo complementou essa questão retificando a "impressão" por "alteração" na alma, pois cada nova marca se estabelece ali sem que as demais sejam apagadas. Cada nova marca se somaria às já existentes, posto que essas não sejam apagadas para dar lugar a uma nova, por isso, definir como "alteração" parece mais apropriado se considerarmos que o ser humano tende a aumentar seu repertório em várias áreas e as coisas que vemos não apagam as demais da nossa memória.

Sob o postulado de que os sentidos são confiáveis para os estóicos, consequentemente, as fantasias são também, uma vez que se processam por meio dos sentidos - temos então a fantasia apreensiva (ou compreensiva). No entanto, a apreensão manifestada pela fantasia é criticada por alguns acadêmicos, pois se a cognição e a percepção do objeto forem falsas, a fantasia também será; não haverá 
compreensão, dessa maneira, a verdade não pode ser buscada por essa via. A enargia é colocada como um efeito próximo da verdade, pois nada é mais claro do que ela, conforme afirmação de Cícero em Academica.

A clareza é o pré-requisito para a verdade, mas como dispositivo retórico a evidência não necessariamente quer dizer a verdade, mas é a impressão de realidade. Devemos ter cuidado ao pensar na enargia do contexto filosófico e no campo da produção retórico-poética. A fantasia projeta a enargia no âmbito ficcional, proporcionando a atividade pela qual se produz a representação.

Para os epicuristas, a enargia é uma evidência dos sentidos, a qual, segundo nos afirma Sexto Empírico, corresponde à fantasia que, assim como os sentidos, é uma afecção. A fantasia só pode ser verdadeira se originar-se de um objeto - phantaston verdadeiro, proposição também dos estóicos.

É discutível se a fantasia é produtora de verdade também em razão da percepção, em várias doutrinas são recorrentes os exemplos de visão que dependem das condições do espectador: o sol, embora nossa razão indique-o como grande, a percepção que temos dele não corresponde a essa imagem. Isso não implica que a visão seja falsa, apenas que a percepção tem limitações físicas e a fantasia reproduz os resultados dela. Logicamente, concordaríamos com Platão que não podemos confiar naquilo que pertence ao mundo visível; mas a fantasia, ainda que não represente a verdade, representa uma realidade como a percebemos e é nisso que consiste o processo imaginativo.

Os tratados apresentados no capítulo anterior permitiram observar uma tipologia, ainda que obscurecida pelas discussões entre as escolas filosóficas. Ildefonse ${ }^{84}$ sistematizou a "classificação" das fantasias que resumo a seguir e tem como base as citações de Diógenes Laércio e Sexto Empírico.

As fantasias podem ser sensíveis quando são percebidas pelos órgãos de sentido e não-sensíveis quando percebidas pelo pensamento. Temos ainda as fantasias lógicas que ocorrem aos animais dotados de lógos e, as não-lógicas, nos animais desprovidos de razão discursiva.

A fantasia transitiva (metabatiké) é um tipo que permite a composição a partir das informações perceptivas que temos, possibilitando dessa maneira as fantasias nãosensíveis por meio de relações (como a semelhança, a analogia, a transferência, etc.).

${ }^{84}$ Cf. nota 43. 
Sexto menciona as fantasias técnicas que são diferentes das não-técnicas, dependendo da percepção do indivíduo que pode ou não ter conhecimento diferenciado acerca do objeto visto. Ele nos apresenta também a fantasia provável, a improvável, uma que é ao mesmo tempo provável e improvável e outra nem provável ou improvável. Estas, por sua vez, dividem-se quanto ao fato de serem verdadeiras ou falsas.

A fantasia compreensiva é a considerada verdadeira pelos estóicos, cuja contraposição é a não-compreensível, que é aquela experimentada por alguém doente ou insano, mesmo que seja verdadeira, não será compreensível. A compreensiva reproduz as características do objeto e permite seu assentimento e, em seguida, sua apreensão.

Longino destaca dois tipos de fantasia: oratória (retórica) e poética - na primeira, a finalidade é conferir vivacidade (enárgeia) à imagem e na outra é maravilhar seu público. Até agora analisamos a fantasia filosoficamente, mas Longino a classifica de tal maneira que a associa à enargia e à écfrase, inclusive, ao chamá-la "idolopeia" adentramos na dimensão da écfrase - portanto, representa aqui um dispositivo retórico.

Dada a tradição, conforme verificado no primeiro capítulo, preferimos entender a fantasia como parte de um complexo processo que reside no indivíduo, não pode, portanto, ser restrita aos domínios retóricos. Longino a demonstra como o mecanismo a partir do qual se produz a enargia, obviamente a fantasia permite a enargia: aquela depende de um exercício interno processado pelo indivíduo que resulta justamente dos recursos adotados (dentre eles, a écfrase) para se produzir a enargia no âmbito retóricopoético.

Lausberg, §810, define a evidência como a descrição viva e detalhada de um objeto, mediante a enumeração de suas particularidades sensíveis, quer sejam reais ou inventadas pela fantasia.

Webb $^{85}$ afirma que a fantasia é, ao mesmo tempo, a causa e o efeito da enargia, mas que o emprego do termo fantasia é vago, como já ressaltamos: por vezes significa a faculdade da imaginação, outras, as próprias imagens mentais.

Observa-se que a enargia necessita da fantasia; logo, será inerente à écfrase produtora de enargia também. O papel por cada uma desempenhada é de difícil delimitação, pois o que se apresenta é um processo de interdependência.

${ }^{85}$ Cf. nota 80 . 


\section{Aplicação dos procedimentos}

A finalidade desse capítulo é estudar a aplicação dos recursos que foram até agora teorizados. As discussões anteriormente levantadas quanto à definição e função de cada processo poderão ser verificadas a partir dos exemplos, numa tentativa de confirmar as conclusões aqui propostas.

A poesia, desde Homero, apresenta inúmeros casos de evidência ou écfrase nos mais diversos gêneros, portanto, limitamos nosso corpus às ocorrências em três gêneros, a saber: o épico, a monografia histórica e a vida (biografia). Dessa maneira, observaremos as particularidades de tais procedimentos em cada um desses gêneros.

No épico analisaremos as passagens da Eneida que utilizam a écfrase para produzir os efeitos de visualização, que são os cantos: I, 455-95; II, 199-224; V, 250-54; VI, 18-35; VII, 783-92; VIII, 624-728; X, 495-500. Estudaremos também a écfrase no poema épico de Catulo - 64. Adotamos as monografias históricas de Salústio, a Guerra de Jugurta e a Conjuração de Catilina, das quais selecionamos os capítulos que apresentam retratos de personagens para tratar da etopeia e averiguar os efeitos produzidos por essa figura que utiliza recursos ecfrásticos: da primeira, 6, 63, e, da segunda, 5, 25, 53, 54. Para o gênero biográfico, adotamos alguns capítulos do Divino Júlio de Suetônio, com o mesmo objetivo de estudar como se processa a etopeia, que são: $1,2,3,6,14,31,37,44,45,55,57,72$ e 88.

\section{III.1. ENEIDA}

O estudo das passagens ecfrásticas foi realizado com base em tradução própria, que antecede às analises, e também nas consagradas traduções de Carlos Alberto Nunes e de Odorico Mendes. Os textos latinos foram extraídos de edições da Les Belles Lettres.

\section{As pinturas do templo \\ I, 450-97}

Hoc primum in luco noua res oblata timorem/ leniit, hic primum Aeneas sperare salutem/ ausus et adflictus melius confidere rebus. 
Aqui, nesse bosque sagrado, pela primeira vez, um novo fato apresentado acalmou/ seu temor, então, Eneias logo ousou esperar a salvação/ e, aflito, confiar mais na sorte.

Namque sub ingenti lustrat dum singula templo/ reginam opperiens, dum quae fortuna sit urbi/ artificumque manus inter se operumque laborem [455] miratur, uidet Iliacas ex ordine pugnas/ bellaque iam fama totum uolgata per orbem,/ Atridas Priamumque et saeuom ambobus Achillem.

Porque, enquanto ele aguarda a rainha, examina cada uma das coisas no soberbo templo, que é a fortuna da cidade, e admira suas obras, os trabalhos dos artífices e vê em ordem as batalhas da Ilíada e as guerras, com a fama já divulgada por toda a orbe, os Atridas, Príamo e Aquiles, cruel para ambos.

Constitit et lacrimans "Quis iam locus" inquit "Achate, [460]/ quae regio in terris nostri non plena laboris?/ En Priamus. Sunt hic etiam sua praemia laudi,/ sunt lacrimae rerum et mentem mortalia tangunt./ Solue metus; feret haec aliquam tibi fama salutem."

Deteve-se e, chorando, diz: "Acates, que lugar, qual região da terra não está cheia do nosso sofrimento? Eis aqui Príamo. Também aqui o louvor tem seus benefícios, as lágrimas são pelos acontecimentos e as desgraças humanas impressionam a mente. Afasta os temores; essa fama te trará alguma salvação."

Sic ait atque animum pictura pascit inanil multa gemens, largoque umectat flumine uoltum. [465]

E assim (Eneias) diz, apascenta o espírito com numerosas pinturas vazias, chorando, umedece as faces com copioso rio.

Namque uidebat uti bellantes Pergama circum/ hac fugerent Grai, premeret Troiana iuuentus, I hac Phryges, instaret curru cristatus Achilles.

Pois aqui ele vê como os guerreiros graios (gregos) fugiam por todas as partes ao redor de Pérgamo, a juventude troiana os abatia, ali os frígios, Aquiles, de capacete, os perseguia com o carro.

Nec procul hinc Rhesi niueis tentoria uelis/ agnoscit lacrimans, primo quae prodita somno [470] Tydides multa uastabat caede cruentus, / ardentisque auertit equos in castra prius quam/ pabula gustassent Troiae Xanthumque bibissent.

Perto disso, lacrimejando, reconhece as tendas de Reso, de panos níveos, as quais foram arruinadas no primeiro sono, Tidide (Diomedes) sanguinário devastava muitas com a carnificina, afastou os cavalos reluzentes para o acampamento antes que provassem os pastos de Troia e bebessem do Xanto. 
Parte alia fugiens ammissis Troilus armis, infelix puer atque impar congressus Achilli, [475]/ fertur equis curruque haeret resupinus inani,/ lora tenens tamen; huic ceruixque comaeque trahuntur/ per terram, et uersa puluis inscribitur hasta.

Em outra parte, Tróilo foge, tendo perdido as armas, garoto infeliz e desigual no combate com Aquiles, é carregado pelos cavalos e, derrubado, fica suspenso do carro vazio, ainda tem as rédeas; a cerviz e os cabelos são arrastados para ele pela terra, e a poeira é inscrita pelo dardo virado.

Interea ad templum non aequae Palladis ibant/ crinibus Iliades passis peplumque ferebant $[\mathbf{4 8 0}]$ suppliciter, tristes et tunsae pectora palmis;/ diua solo fixos oculos auersa tenebat.

Enquanto isso, as Ilíadas iam para o templo de Palas hostil com os cabelos desgrenhados e, humildemente, levavam o manto, tristes, batiam no peito com as mãos; a deusa inimiga tinha os olhos fixos no chão.

Ter circum Iliacos raptauerat Hectora muros/ exanimumque auro corpus uendebat Achilles.

Aquiles arrastara Heitor três vezes nas imediações dos muros ilíacos e vendia seu corpo inanimado a preço de ouro.

Tum uero ingentem gemitum dat pectore ab imo, [485] ut spolia, ut currus, utque ipsum corpus amici/ tendentemque manus Priamum conspexit inermis.

Então ele dá um forte gemido do fundo do peito ao divisar os despojos, o carro e o corpo do próprio amigo, e Príamo estendendo as mãos fracas.

Se quoque principibus permixtum agnouit Achiuis,/ Eoasque acies et nigri Memnonis arma.

Também se reconheceu, misturado entre os principais aquivos, e os exércitos orientais, as armas do negro Memnão.

Ducit Amazonidum lunatis agmina peltis [490] Penthesilea furens mediisque in milibus ardet,/ aurea subnectens exsertae cingula mammae/ bellatrix, audetque uiris concurrere uirgo.

Pentesileia comanda os batalhões das Amazonas com escudos em forma de lua e resplandece furiosa no meio de milhares, a guerreira traz um talabarte dourado sob a mama descoberta, e a virgem ousa lutar contra os homens.

Haec dum Dardanio Aeneae miranda uidentur,/ dum stupet obtutuque haeret defixus in uno, [495] regina ad templum, forma pulchrerrima Dido,/ incessit magna iuиenum stipante caterua. 
Enquanto essas pinturas parecem admiráveis para o dardânio Eneias, fica estupefato e imóvel com a contemplação de uma única pintura, a rainha Dido, a mais bela em aparência, entra no templo rodeada com grande multidão de jovens.

Nota-se que a maior parte dos verbos nessa passagem pertence ao tempo presente do indicativo, seguido das formas nominais do particípio presente e particípio pretérito.

As ações no presente não são adotadas somente para representar o momento em que Eneias observa as imagens no templo de Juno; as imagens da parede são descritas também com o tempo presente, conferindo mais movimentação às cenas destacadas, que recordam eventos ocorridos durante a guerra de Troia:

\section{[...] fugiens amissis Troilus [...] fertur equis curruque haeret. [v.474-76]}

[...] huic ceruixque comaeque trahuntur/ per terram, et uersa puluis inscribitur hasta. [v.477-78]

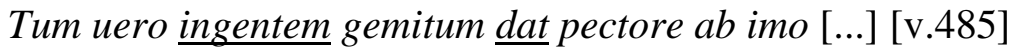

Ducit Amazonidum lunatis agmina peltis/ Penthesilea furens [...] ardet [...] audetque uiris concurrere uirgo. [v.490-93]

Williams ${ }^{86}$ explica que, no verso 474, a expressão "amissis... armis" revela eventos implícitos na cena, pois Tróilo já é retratado sem as armas. O particípio pretérito cumpre bem essa função, permitindo entrever detalhes da ação.

A coloração é indicada em algumas passagens, possibilitando a imediata visualização da cena. Em meio à batalha, expressões que traduzem a crueldade nos remetem ao sangue e, consequentemente, à imagem avermelhada desse, tal como "caede cruentis" (v.471). No verso 489, Menão é caracterizado como negro.

O léxico referente à luz, obviamente, nos lança no campo do visível: ardentis (v.472) e $\operatorname{ardet}(\mathrm{v} .41)$.

O detalhamento da matéria-prima que aparece nessa passagem, no verso 492 , referida pelo adjetivo "aurea" indica ao mesmo tempo o material do objeto figurado e sua coloração.

\footnotetext{
${ }^{86}$ WILLIAMS, R. D. “The pictures on the Dido's Temple”. In: Classical Quarterly. 1960, 10, pp.145-51.
} 
Podemos ver junto com Eneias as imagens, introduzidas pelo verbo "uidet", verbo que se repete no verso 466 (uidebat); "conspexit" aparece mais adiante como sinônimo, também para indicar o que o herói vê.

Sabemos estar diante de pinturas por meio da expressão "pictura inani” (v.464) que nutre o espírito do herói, apesar de adjetivada como algo vazio, inane. As cenas mostradas revelam detalhes de fatos conhecidos da guerra troiana, que comovem o herói, chorando copiosamente - em cada cena percebemos indícios da derrota troiana. Aqui o pranto do herói é comparado ao rio, um símile que reforça a tese de que a écfrase é preenchida por diversas figuras para produzir o efeito esperado.

Aparece a deusa Atena em dado momento, a quem as troianas rogam auxílio, cuja imagem de "fixos oculos" (v.482) nos permite inferir que se trata não apenas de sua representação material no templo, imutável, mas observamos a própria deusa ignorando os pedidos.

Essa passagem também se destaca pelo retrato apresentado das troianas, as quais foram ao templo com os cabelos desgrenhados, vestidas com o manto e entristecidas. Aqui há certa progressão de ações, pois as vemos partir até o templo e, ao chegar, fazem suas preces batendo no peito. Embora breve, temos um quadro bem acabado das personagens. O advérbio “interea" (v.479) já antecipa a progressão da cena, introduzindo essa parte da pintura.

Outro retrato é o de Pentesileia, cuja descrição e ação na batalha resumem-se em quatro versos (490-93), fornecendo também o retrato das amazonas que a seguem.

Nos dois casos acima, confirmamos a associação da écfrase com a prática do retrato que, inseridos na ação épica, são revestidos também de progressão de eventos, destituindo-lhes do caráter estático.

A pintura tem um artífice e, embora não saibamos quem seja, algumas vezes o poeta deixa implícita essa ideia. No verso 455, o herói admira o trabalho dos artífices antes da descrição iniciar: artificumque manus inter se operumque laborem/miratur.

Observamos que as funções retóricas são expressas a partir do verbo "miratur" (v.456) e "miranda" (v.494), consolidando a aplicação de preceitos retóricos como norteadores das artes em geral, visto que a arte visual também precisa afetar o espectador de alguma maneira; nessa passagem ecfrástica, a reação de Eneias indica que as imagens, sobretudo, o comovem, mas também agradam, pois a precisão narrativa o impressiona. No fim da descrição, corrobora-se o caráter de admiração do herói com o verbo "stupet" (v.495). 
Tratando-se de uma imagem, as referências espaciais são necessárias para que o leitor seja capaz de elaborar mentalmente um quadro da imagem, ainda que a ordenação das cenas não resulte em um quadro claro. No verso 466, "Pergama circum" fornece o cenário no qual os troianos venciam os gregos; no verso seguinte, o advérbio "hac" mostra que perto dessa ação, outra está transcorrendo. Mais adiante, a expressão "Nec procul hinc" (v.469) direciona o leitor para outro acontecimento que está representado perto da anterior. "Parte alia" (v.474) nos direciona para o lado possivelmente oposto, onde Tróilo foge de Aquiles e sua cabeça é arrastada "per terram" (v.478) - temos aqui a localização de outro elemento inserido na narrativa, o local onde Tróilo é arrastado, chamando a atenção sobre a figuração detalhada, uma vez que não formaria um todo coerente se as personagens estivessem simplesmente lançadas aleatoriamente. No verso 491, Pentesileia aparece resplandecendo no meio (mediisque in milibus) de todos.

O verso 474, como vimos, introduz uma outra parte da imagem, estrutura-se aproximadamente no meio da écfrase; poderíamos supor (digo supor porque a transcrição de uma imagem para a expessão verbal não pode ser exata) que essa écfrase concentra dois blocos que apresentam progressivamente os acontecimentos da guerra. $\mathrm{O}$ segundo bloco direciona a história para a derrota troiana.

No contexto bélico, a enumeração de elementos é necessária para engrandecer as narrativas; com o propósito de resumir a guerra de Troia, a écfrase apresenta as personagens, por vezes, enumerando-as, reunindo brevemente várias personagens relevantes. É o que ocorre no verso 458, no qual desfilam os Átridas, Príamo e Aquiles ao mesmo tempo. Outro exemplo é quando o Menão aparece juntamente com os aquivos e os exércitos orientais e, logo em seguida, surge Pentesileia (v.488-90).

Emprega-se apóstrofe no verso 459, em que Eneias interrompe o curso da descrição e fala com Acates.

A intersecção entre o meio verbal e o visual é destacado na parte em que a haste de Tróilo escreve na poeira enquanto ele é arrastado no carro: "uersa puluis inscribitur hasta" (v.478).

Quando o herói geme ao ver o corpo de Heitor sendo arrastado (v.485), temos uma noção da sua agonia ao rever os acontecimentos da guerra. A imagem que podemos fazer dele no momento lembra o desespero de Laocoonte no livro II, ao soltar clamores horrendos. 


\section{Laocoonte \\ II, 199-224}

Hic aliud maius miseris multoque tremendum/ obicitur magis atque improuida pectora turbat. [200]

Então outra coisa, maior do que as desgraças e muito mais terrível, se apresenta (aos olhos) e perturba os desatentos espíritos.

Laocoon, ductus Neptuno sorte sacerdos,/ sollemnis taurum ingentem mactabat ad aras.

Laocoonte, o sacerdote tirado à sorte por Netuno, com solenidades imolava um touro forte diante dos altares.

Ecce autem gemini a Tenedo tranquilla per altal (horresco referens) immensis orbibus angues/ incumbunt pelago pariterque ad litora tendunt; [205]/ pectora quorum inter fluctus arrecta iubaequel sanguineae superant undas, pars cetera pontum/ pone legit sinuatque immensa uolumine terga.

Eis, de repente, (estremeço ao relatar) serpentes gêmeas, de anéis imensos, atacam do sereno Tênedo para o mar alto e, ao mesmo tempo, dirigem-se do mar para as margens; das quais, os peitos, erguidos entre as vagas, e as caudas sanguinárias ultrapassam as ondas, o resto do corpo (atrás), as costas imensas, segue com um giro e encurva-se para o mar.

Fit sonitus spumante salo; iamque arua tenebant/ ardentisque oculos suffecti sanguine et igni [210] sibila lambebant linguis uibrantibus ora.

Um estrondo soa no mar espumante; agora tomam as margens e os olhos sedentos, tingidos de sangue e fogo, lambiam as bocas sibilantes com línguas vibrantes.

Diffugimus uisu exsangues. Illi agmine certo/ Laocoonta petunt; et primum parua duorum/ corpora natorum serpens amplexus uterque/ implicat et miseros morsu depascitur artus; [215]/ post ipsum auxilio subeuntem ac tela ferentem/ corripiunt spirisque ligant ingentibus; et iam/ bis medium amplexi, bis collo squamea circum/ terga dati superant capite et ceruicibus altis.

Pálidos, fugimos da visão. Elas, certamente, buscam Laocoonte na multidão; primeiramente, ambas as serpentes apertam e enroscam os corpos pequenos dos dois filhos e devoram os míseros membros com uma mordida; depois, agarram o próprio Laocoonte, que vem em socorro e leva armas, e o prendem com as enormes espirais; nesse intervalo, por duas vezes o apertaram, duas vezes o pescoço os corpos escamosos estendiam-se-lhe ao redor, com a cabeça e as cervizes elevadas. 
Ille simul manibus tendit diuellere nodos $[220] /$ perfusus sanie uittas atroque ueneno,/ clamores simul horrendos ad sidera tollit:/ qualis mugitus, fugit cum saucius aram/ taurus et incertam excussit ceruice securim.

Ele esforça-se para desprender os nós com as mãos, banhado de sangue e de negro veneno nas fitas, e ao mesmo tempo lança clamores horrendos aos astros: tal como um mugido quando o touro ferido foge do altar, tendo derrubado o machado perigoso na cerviz.

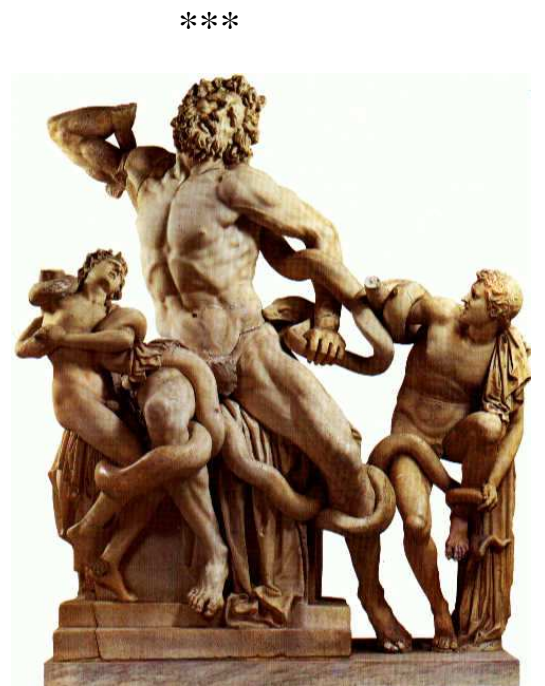

\section{Grupo de Laocoonte - Museu do Vaticano}

Eneias narra para a rainha Dido a passagem do sacerdote Laocoonte, não se trata da descrição de objeto material - como observamos nos outros casos do poema contudo, conhecemos a escultura do Grupo de Laocoonte que mostra o sacerdote e seus filhos sendo atacados pelas serpentes, ainda que o exemplar romano seja posterior ao poema, é possível tratar-se da cópia de uma escultura grega mais antiga - nisso residiria a écfrase como gênero descritivo de obras, uma vez que seria a descrição verbal de uma escultura.

Independentemente de ser a écfrase de uma obra, a descrição operada nessa passagem serve como meio para produzir a evidência da cena narrada.

O tempo verbal predominante é o presente do indicativo, com ocorrência menor e mais equilibrada estão o pretérito perfeito e as formas nominais do particípio pretérito e particípio presente - está bem próximo da frequência verbal do livro I. A predominância do tempo presente permite presentificar as ações, mesmo narrando um fato passado, conferindo assim mais vivacidade à cena - essa transposição de tempo já vimos em Quintiliano (IX, II, 41) como uma das formas pela qual a enargia se manifesta. 
A temática da cena é violenta, de modo que, para transmitir o horror, a coloração avermelhada do sangue é recorrente. É o que ocorre em "iubae sanguineae" (v.207) na descrição das serpentes; no verso 210, "oculos suffecti sanguine et igni” prosseguem com a descrição, com destaque para os olhos que estão injetados de sangue, transmitindo mais intensamente o estado das serpentes.

No verso 212, o adjetivo "exsangues" nos mostra como o espectador da cena se comporta, contrastando com as serpentes, pois a visão cruel dos monstros sanguinários deixa a todos pálidos, que evitam olhar - "Diffugimus uisu". A imagem aqui cumpriria apenas a função de comover, posto que a visão de tais infortúnios não agrade. A própria introdução da imagem (v.199-200) deixa evidente que o que se vai narrar é terrível e perturba os corações (pectora turbat) quando se visualiza (obicitur) o acontecimento.

Na finalização do quadro (v.221), Laocoonte está banhado de sangue, "perfusus sanie", e do negro veneno, "atro ueneno" - destacando o estado precário da personagem.

O mar transmite também uma ideia de sua coloração em "spumante salo" (v.209) - a espuma do mar já nos leva a imaginá-lo quando agitado, com o branco espumando e contrastando com o restante da cena, repleta pelo vermelho do sangue.

A narração se passa como rememoração de uma ação, portanto, alguns dos tópicos empregados no primeiro livro são dispensáveis aqui, ainda que a descrição seja de fato ecfrástica, trata-se de um evento conhecido da guerra de Troia, não de uma obra.

A narração é introduzida pelo advérbio "hic" (v.199) e as serpentes são apresentadas pelo advérbio "ecce" no verso 203. O sacerdote é localizado no cenário "ad aras" (v.202) ao imolar um touro.

A ação transcorre convencionalmente, as serpentes agindo praticamente a cena toda. A progressão da ação pode ser percebida entre os versos 213 e 219 com os advérbios primum e post, dirigindo-se primeiramente aos filhos e depois a Laocoonte. A reação de Laocoonte é mostrada simultaneamente à das serpentes, como percebemos no verso 220, indicação apontada pelo advérbio "simul", e visualizamos então todo o esforço dele para se livrar do ataque.

A imensidão das serpentes é demonstrada quando colocadas no próprio ambiente marítimo, pois elas "superant undas".

O discurso verbal contribui para a vivacidade da narrativa quando o sacerdote lança "clamores horrendos" (v.222) e essa manifestação de dor é comparada ao mugido, tal qual o touro que seria sacrificado e foge, neste momento, do altar; Laocoonte, no 
entanto, não pode fugir. Temos o símile do sacerdote com o touro, conferindo-lhe a condição de sacrifício necessário para a vitória dos gregos.

Outras figuras são também adotadas nessa passagem, tal como a aliteração no verso 209 que repete o som consonantal "S". Morganti ${ }^{87}$ faz uma interessante análise dessa passagem: o som remete à espuma do mar produzida pelo movimento das serpentes. A autora também destaca o efeito sonoro produzido no verso 211 , em que a repetição da letra "L" faz com que o texto reproduza o mesmo tipo de som emitido pelas serpentes.

Insiro aqui uma breve digressão para demonstrar a importância dessa narrativa ecfrástica. Na obra Satyricon, de Petrônio, a personagem Eumolpo faz uma defesa da pintura, após o discurso, ele descreve o quadro que vê (capítulo LXXXIX), parodiando o canto II da Eneida de Virgílio. Logicamente, a descrição apresenta algumas distinções, mas muito se assemelha à narração de Virgílio.

Na Eneida, Virgílio utilizou a écfrase que consiste na representação verbal de uma imagem, se aceitarmos a preexistência da escultura - deste modo, ele aproximou a poesia das artes visuais; no Satyricon $^{88}$, um quadro é transformado em poema, estabelecendo a mesma relação que se observa no livro I da Eneida.

Petrônio resumiu em 65 versos todos os acontecimentos da tomada de Troia, embora se concentre na cena de Laocoonte, temática presente em grande parte do segundo canto da Eneida.

A personagem Sinão aparece de imediato na paródia, antes mesmo de Laocoonte, este adiantamento parece acelerar os acontecimentos porque os troianos não duvidaram do ardil. Laocoonte, então, levanta a dúvida que é logo dissipada por causa do castigo sofrido por ele e seus filhos. Na Eneida, o sacerdote logo duvida do presente, em seguida, Sinão discursa longamente, conseguindo convencer as pessoas, neste momento, Laocoonte é morto. Esta pequena inversão é importante para agilizar a narrativa e passar logo para a cena que importa à écfrase; no entanto, observamos uma quebra no padrão acelerado da paródia ao relatar a morte do sacerdote, de modo que ocupa quase a mesma quantidade de versos da epopeia.

\footnotetext{
${ }^{87}$ MORGANTI, B. F. "A morte de Laocoonte e o Gigante Adamastor: a écfrase em Virgílio e Camões". In: Nuntius Antiquus. Belo Horizonte: Universidade Federal de Minas Gerais. 2008, n 1, pp.1-13.

${ }^{88}$ Para todas as citações do Satyricon utilizamos a tradução de Sandra Bianchet. Belo Horizonte: Crisálida. 2004.
} 
Na paródia, esta cena inicia-se no verso 29 e segue até o verso 52; na epopeia, inicia-se no verso 201 até o verso 223. O aparecimento das serpentes é introduzido pelo mesmo advérbio "ecce" em ambos.

Se considerarmos as traduções consagradas dos textos, constatamos a semelhança das sentenças, embora no texto original os autores tenham se utilizado de palavras diferentes em passagens muito semelhantes.

Algumas dessas particularidades merecem ser citadas:

[...)] gemini [...]/immensis orbibus angues (Eneida, II, v. 203-4)

[...] angues orbibus geminis (Satyricon, LXXXIX, v.35)

Virgílio deixa evidente que há duas serpentes gêmeas, Petrônio, porém, descreve as serpentes não como iguais, mas possuidoras de "anéis gêmeos", conforme a tradução: “[...] as ondas lançam nas pedras/ serpentes de duas cabeças [...]” (v. 35-6). Esta descrição gera certa ambiguidade ao texto - pode-se entender que há uma serpente de duas cabeças ou duas serpentes com duas cabeças cada - mas o leitor que já conhece a descrição da Eneida, dificilmente, terá dúvidas.

Mais adiante encontramos outra expressão semelhante nos dois textos:

"Todos, a uma, a cidade invadiram, no sono e no vinho/ como que imersos [...]" (Eneida, II, v.264-5 - Trad. C.A. Nunes)

"[...] à noite e sob o efeito do vinho" (v.56); "os embriagados pelo vinho e une à morte extrema/ o sono destes [...]” (Satyricon, LXXXIX, v.63-4)

Pela tradução, notamos a semelhança das sentenças, que se referem à forma como os troianos estavam no momento em que foram abordados pelos gregos. No entanto, Virgílio utilizou a palavra "uinum”: “[...] somno uinoque sepultam” (v. 265), que transmite a ideia de que a cidade comemorou o fim da guerra; enquanto Petrônio utilizou "merum": "[...] nocte et mero" (v.56), para designar a bebida, provavelmente para diferenciar o grau de embriaguez, que parece, na sátira, ser exagerado.

Deste modo, Petrônio faz uma crítica aos vícios dos homens, neste caso, o estado de embriaguez e sono dos troianos parece ser o motivo que permite a fácil vitória dos gregos. 
A escultura de Laocoonte referente a essa passagem é tema do livro Laocoonte $^{89}$ de Lessing (séc.XVIII), no qual expõe questões concernentes à relação entre as artes verbais e visuais. Para ele, a progressão temporal pertence ao domínio do poeta, enquanto o espaço é o domínio do pintor e do escultor. No entanto, a écfrase permite, em certa medida, a intersecção entre os dois domínios, já que tenta tornar visível não apenas o objeto, mas seu conteúdo, pois veicula narrações que podem ser depreendidas das imagens.

Ainda que admitíssemos que a écfrase de Virgílio represente a escultura, a representação verbal distingue-se da visual, uma vez que cada linguagem tem seus preceitos; a transcrição exata dos detalhes da escultura não reproduziriam decorosamente a imagem. Lessing discutiu longamente a respeito dessas particularidades em sua obra e tratarei de expor algumas ${ }^{90}$.

$\mathrm{Na}$ Eneida o sacerdote está acompanhado dos filhos, imolando um touro, quando são atacados - tal situação só pode ser demonstrada na narrativa, a escultura só é capaz de expor um momento da ação.

No poema imaginamos as personagens vestidas, ao contrário da escultura na qual todos aparecem nus. Isso ocorre para que vejamos as reações físicas das personagens, tal como a contorção dos músculos, demonstrando o imenso esforço feito; na imagem verbal, a descrição pode narrar os detalhes da cena para traduzir esse esforço.

O horror da cena é transmitido na narração por meio de expressões do narrador, como "horresco referens" ou "diffugimus uisu", que traduzem o medo do espectador da cena.

Na escultura vemos realmente os corpos cansados da luta, com os músculos retesados. O sacerdote não está gritando, diferentemente do poema, mas parece proferir uma súplica aos céus.

Percebemos que as serpentes envolvem o corpo todo dos meninos e do sacerdote na narração; ao passo que na escultura a parte superior dos corpos fica praticamente livre, dessa maneira, os detalhes do esforço físico ficam expostos e, embora seja uma obra estática, fazemos ideia dos movimentos das personagens para se desvencilharem das serpentes.

\footnotetext{
${ }^{89}$ LESSING. Laocoonte ou Sobre as Fronteiras da Pintura e da Poesia. Tradução de Márcio SeligmannSilva. São Paulo: Iluminuras. 1998. Cf. capítulo XVIII.

${ }^{90}$ Essa temática se concentra especialmente até o capítulo VI, mas a discussão permanece em todo o tratado.
} 
O sangue descrito no poema serve para dar mais vivacidade à cena, indicando coloração; é, contudo, desnecessário na escultura, em razão da matéria-prima utilizada, o sangue é um elemento que poderia ser mal representado, indecoroso para o tipo de representação.

Ainda que o canto II não se baseie de fato na escultura, é interessante comparar os dois retratos de uma mesma imagem: verbal e visual.

\section{Clâmide $\mathrm{V}, \mathbf{2 5 0 - 5 4}$}

uictori chlamydem auratam, quam plurima circum/ purpura Maeandro duplici Meliboea cucurrit,/ intextusque puer frondosa regius Idal uelocis iaculo ceruos cursuque fatigat/ acer, anhelanti similis $[\ldots]$

Ao vencedor uma clâmide de ouro, a qual se circunda com bordado duplo, cheio de púrpura melibéia, um rapaz régio é representado, ele persegue os cervos no Ida frondoso com o dardo de velocidade e com a corrida, forte, parece arquejar [...].

$* * *$

Essa breve écfrase detalha a imagem do manto dado como prêmio ao vencedor dos jogos em homenagem a Anquises. A ação é reduzida, mas a descrição serve para enaltecer o prêmio, pois a imagem parece viva; vemos, de certa maneira, o rapaz caçando os cervos.

Por ser diminuta, o caráter é mais estático, ainda que narre a ação; a brevidade aqui contribui para dar mais vivacidade ao objeto descrito, visto que o aspecto material é tão detalhado quanto a cena gravada no manto, a enargia gerada pela pormenorização dá início ao processo imaginativo que provoca no leitor a fantasia não somente da aparência do objeto, como também da narração que o subjaz.

Os poucos verbos predominam no perfeito. Temos duas ocorrências de particípio que servem como adjetivos: auratam e intextus - verbos que servem para indicar também tratar-se de uma representação imagética, uma vez que remetem para características de uma obra feita por algum artífice. Além disso, "aurata" nos remete a um só tempo ao material do objeto e também a sua cor. A cor do bordado não é apenas caracterizada como purpura, mas é ainda mais específica remetendo-se à "purpura Meliboea", cuja qualidade é estimada. 
O emprego do presente do indicativo "fatigat" e do particípio presente "anhelanti" permitem que o leitor perceba a disposição da personagem no momento da ação, tornando menos estático o quadro apresentado.

Williams afirma que a écfrase do livro $\mathrm{V}$ é simplesmente decorativa ${ }^{91}$, ao passo que as demais estão integradas à ação do poema. Em relação às demais écfrases do poema que estamos analisando, de fato, essa parece deslocada, pois as passagens que usam esse mecanismo o adotam como um meio diferenciado de realizar a narrativa, cuja temática costuma abordar a guerra de Troia ou a história romana.

Entretanto, na entrada do templo de Apolo, por exemplo, narra-se um mito que não pertence ao mesmo eixo temático, mas antecipa uma importante parte da narrativa quando Eneias saberá sobre o futuro de seu povo - funciona, de fato, como digressão, mas realçando a expectativa em torno do que será narrado a seguir.

As écfrases na Eneida funcionam, portanto, como dispositivos que destacam algumas ações de proporções épicas e, ainda que isoladas da ação principal do poema, associam-se a ela de alguma maneira.

$\mathrm{A}$ écfrase no canto $\mathrm{V}$ confere destaque à passagem da premiação do vencedor dos jogos em honra a Anquises, evento também presente no poema homérico em homenagem a Pátroclo (Ilíada, XXIII), circunscrevendo-se na tradição da poesia épica. O tratamento dado por Virgílio é diferenciado, demonstra-se a grandeza do prêmio, ao passo que, na Ilíada, os prêmios são enumerados a princípio e descritos rapidamente quando entregues.

\section{As portas do templo de Apolo VI, 18-35}

Redditus his primum terris tibi, Phoebe, sacrauit/ remigium alarum posuitque immania templa.

Lançado a essas terras, primeiro, oh Febo, sagrou-te os remos de asas e edificou um admirável templo.

In foribus letum Androgeo; tum pendere poenas [20]/ Cecropidae iussi (miserum!) septena quotannis/ corpora natorum; stat ductis sortibus urna.

\footnotetext{
${ }^{91}$ WILLIAMS, R. D. “The Pictures on Dido's Temple”. In: The Classical Quarterly, vol.10, nº pp. 145151. Cf. pp.148.
} 
Nas portas, a morte de Andrógeo; depois, os Cecrópidas, os quais foram obrigados a pagar uma pena (oh miserável!), todos os anos entregar sete corpos de filhos; ergue-se a urna nas sortes tiradas.

Contra elata mari respondet Gnosia tellus:/ hic crudelis amor tauri suppostaque furto/ Pasiphae mixtumque genus prolesque biformis [25]/ Minotaurus inest, Veneris monimenta nefandae;

Do lado oposto, a elevada região da Gnósia encontra-se em frente ao mar: aqui, o cruel amor do touro, Pasífaa submetida ao ardil, a espécie misturada e a prole biforme. Encontra-se o Minotauro, monumentos da nefanda Vênus.

hic labor ille domus et inextricabilis error;/ magnum reginae sed enim miseratus amorem/ Daedalus ipse dolos tecti ambagesque resoluit,/ caeca regens filo uestigia. Tu quoque magnam [30]/ partem opere in tanto, sineret dolor, Icare, haberes.

Aqui, a obra da casa e o circuito inextricável; porém, o próprio Dédalo compadeceu-se do grande amor da rainha e desvendou as trapaças da habitação e os enigmas, guiando os passos cegos com um fio. Tu também, oh, Ícaro, terias grande parte em tamanha obra, se a dor permitisse.

Bis conatus erat casus effingere in auro,/ bis patriae cecidere manus. Quin protinus omnia/ perlegerent oculis, ni iam praemissus Achates/ adforet [...] [35]

Duas vezes esforçara-se em representar o caso no ouro, duas vezes as mãos paternas escorregaram. Ainda continuariam percorrendo todas as coisas com os olhos se, agora, Acates não se apresentasse $[\ldots]$.

$* * *$

Os tempos verbais predominantes dessa écfrase são o pretérito perfeito do indicativo, seguido da forma nominal do particípio pretérito e do presente do indicativo, dentre os quais, as ocorrências estão próximas em quantidade. Temos poucas ações presentes nessa descrição, visto que o trabalho de Dédalo funciona como ornamento da entrada do templo. Trata-se do relato do mito do Minotauro, o que justifica o predomínio do tempo pretérito, sua extensão é reduzida, pois é uma digressão que antecipa um evento importante do canto VI: a descida de Eneias ao reino dos mortos.

Embora admiráveis, o próprio herói parece desdenhar um pouco quando desvia o olhar das imagens. Considerando a écfrase do canto VIII (da qual trataremos a seguir), cujo conteúdo ganhou destaque e despertou grande admiração, é possível traçar um paralelo lembrando que aqui o artífice é um mortal, ao passo que no escudo é uma 
divindade; como o poema épico trata daquilo que é superior, poderíamos com isso justificar a preferência de Eneias pela obra de Vulcano.

Ainda que de menor extensão, alguns elementos já observados nas écfrases anteriores também estão presentes. A matéria-prima em que se representa o mito é referida no verso 32: in auro.

O mundo visível infere-se no verso 30 com os "caeca uestigia", uma vez que o labirinto desorienta e a visão não é suficiente para encontrar a saída; e também, no verso 34, "oculis" quando se encerra a descrição afirmando que há ainda muito mais para ser visto.

Há duas ocorrências de apóstrofe: no princípio, quando o poeta invoca Febo (v.18) e no verso 31, quando o artífice Dédalo supostamente se dirige para o filho Ícaro, justificando a ausência deste na obra.

O verbo posuit (v.19) no perfeito do indicativo relaciona a arte com construção, visto que Dédalo esculpiu as imagens nas portas do templo; a associação com a edificação nos remete à eternidade da obra, se rememorarmos a ode de Horácio (livro III, XXX) que afirma ser sua poesia mais duradoura do que o bronze. Além disso, reforça-se a presença do artífice e justifica a necessidade de descrever tamanha obra. $\mathrm{O}$ verbo "effingere" (v.32) refere-se ao campo semântico da representação, reafirmando ser objeto do trabalho de alguém.

Sabemos que a narração do mito está localizada nas portas do templo pela expressão "In foribus" (v.20). Na própria imagem os fatos são apresentados rapidamente, mas mesmo assim há certa orientação espacial. Observa-se que a Gnósia é disposta em frente ao mar ("contra mari" - v.23) e o advérbio hic aparece duas vezes (v.24 e 27) localizando determinado elemento da imagem.

A partir do verso 20, desde o começo da descrição, vemos desfilar uma série de personagens que compõem o mito do Minotauro, que desfilam de maneira tão breve quanto a enumeração de personagens durante a batalha. Ainda assim, a breve écfrase é suficiente para resumir o mito e possibilitar ao leitor um rápido desvio da ação principal por meio da vivência dessa narrativa.

\section{Escudo de Turno}

VII, 783-92 
Ipse inter primos praestanti corpore Turnus/ uertitur arma tenes et toto uertice supra est.

O próprio Turno entre os primeiros preparado com as armas, de corpo notável, se sobressai a todos.

Cui triplice crinita iuba galea alta Chimaeram [785]/ sustinet Aetnaeos efflantem faucibus ignis; / tam magis illa fremens et tristibus effera flammis,/ quam magis effuso crudescunt sanguine pugnae.

Seu elmo elevado ${ }^{92}$, cristado com penacho tríplice, sustenta a Quimera, lançando chamas etneias da garganta; cruel, tanto mais brame com chamas funestas quanto mais aumentam a violência com o sangue derramado no combate.

At leuem clipeum sublatis cornibus Io/ auro insignibat, iam saetis obsita, iam bos, [790] argumentum ingens, et custos uirginis Argus,/ caelataque amnem fundens pater Inachus urna.

Mas Io, no ouro, adornava o escudo polido de chifres erguidos, já novilha coberta de pêlos, poderosa imagem, Argos, o guardião da virgem, e o pai Ínaco vertendo um rio da urna ornada ${ }^{93}$.

$* * *$

A forma verbal mais recorrente é o particípio presente que confere ao mesmo tempo uma característica e uma ação à personagem; fator bem apropriado para uma écfrase breve, pois ainda que os eventos não sejam precisamente narrados, a cena é transcrita de modo que eles estejam implicados na imagem. O particípio pretérito também é frequente, mencionando fatos anteriores ao momento da cena.

A descrição dos preparos para batalhas é comum, conforme afirmado em vários autores dos Progymnásmata, as obras homéricas nos trazem inúmeras descrições de guerreiros aprestando-se para a pugna; nem sempre, no entanto, é dada atenção especial a tais passagens, por isso o escudo de Aquiles ganha tanto destaque na Ilíada. O mesmo ocorre na Eneida, obviamente o escudo de Eneias toma não apenas boa parte do livro VIII, como também se destaca pelo conteúdo; embora o escudo de Turno, antecedendo o canto em que veremos o de Eneias, seja de breve extensão, não deve ser ignorado.

Antes da descrição do escudo, detalha-se o elmo, no qual há uma Quimera enfurecida lançando chamas. Apesar de ser um objeto, a pormenorização da Quimera atribui certo movimento, trata-se de uma única ação, mas temos a impressão de vê-la cuspindo as chamas. O acessório parece estar de acordo com o estado de Turno que segue para a batalha bastante enraivecido, cuja ira foi provocada pela Fúria Alecto.

\footnotetext{
${ }^{92}$ Carlos A. Nunes e Odorico Mendes não traduziram "alta".

${ }^{93}$ Carlos A. Nunes e Odorico Mendes não traduziram "caelata".
} 
Segue-se então a descrição do escudo - introduzido pelo verbo "insignio" que denota ornamentação - cuja narrativa nos traz o mito de Io, por quem Zeus se apaixonara e foi transformada em novilha por ele para escapar de Juno, mas mesmo assim acabou prisioneira desta, vigiada por Argos (o gigante de cem olhos).

O poeta se espanta com a cena por meio da expressão "argumentum ingens" (v.791) - "argumentum" pode ser traduzido como "argumento, assunto", mas optamos aqui pela acepção "imagem"; o termo porta significados que, assim como a écfrase, transitam entre o meio verbal e o não-verbal.

O verbo "caelata", no útlimo verso, é o verbo que remete ao campo semântico da representação.

Uma interessante associação é feita por Gale ${ }^{94}$ entre a imagem do elmo e do escudo: Io é uma vítima dos deuses, assim como Turno que foi manipulado pela vontade de Juno e incitado a voltar à batalha; um pouco antes, no mesmo canto, menciona-se que Turno seria descendente de Ínaco, o pai de Io - estabelece-se uma analogia entre Turno e Io. Por outro lado, Turno aparece sempre bastante exaltado, estabelecendo a analogia com a Quimera do elmo que se opõe à ideia do escudo, visto que deixa de ser vítima para representar o furor, a violência.

Dois elementos servem como indícios de coloração: as chamas, que aparecem na descrição da Quimera, nos versos 786 e 787, sob diferentes denominações - ignis e flammis respectivamente; o sangue, no verso 788, representando as mortes durante a batalha.

O meio material do escudo é referido no verso 790 , onde sabemos que Io foi representada no ouro (auro).

\title{
O escudo de Eneias VIII, 624-728
}

\begin{abstract}
tum leues ocreas electro auroque recocto/ hastamque et clipei non enarrabile textum. [625]/ Illic res Italas Romanorumque triumphos,/ haud uatum ignarus uenturique inscius aeui,/ fecerat ignipotens; illic genus omne futurael stirpis ab Ascanio pugnataque in ordine bella.

Então, as leves armaduras em âmbar e ouro cunhado, a lança e o texto inenarrável do escudo. Nele o Ignipotente forjou eventos da
\end{abstract}

\footnotetext{
${ }^{94}$ GALE, M. R. "The Shield of Turnus (Aeneid 7.783-92)". In: Greece \& Rome. 1997, vol. 44, no2, pp.176-96.
} 
Itália e os triunfos dos romanos, conhecedor do vaticínio e cônscio dos tempos vindouros.

Ali está toda a estirpe de Ascânio e as guerras combatidas sucessivamente.

Fecerat et uiridi fetam Mauortis in antro [630] procubuisse lupam, geminos huic ubera circum / ludere pendentis pueros et lambere matrem / impauidos, illam tereti ceruice reflexam / mulcere alternos et corpora fingere lingua.

E forjara a loba parida ${ }^{95}$ deitada no antro verde de Marte; os gêmeos, unidos ao redor do úbere desta, corajosos, a lamber a mãe e a brincar; ela, tranquila, afagava a ambos alternadamente, com a cerviz encurvada e, com a língua, acariciava-lhes os corpos.

Nec procul hinc Romam et raptas sine more Sabinas [635] concessu caueae magnis Circensibus actis./ addiderat subitoque nouom consurgere bellum/ Romulidis Tatioque seni Curibusque seueris./ Post idem inter se posito certamine reges/ armati Iouis ante aram paterasque tenentes [640] / stabant et caesa iungebant foedera porca.

Não longe disso (forjou) Roma e as sabinas roubadas das grandes festas circenses com a permissão dos espectadores, contra a lei. Acrescentou a nova guerra que insurgira subitamente entre o povo de Rômulo e os cúrios severos e pelo velho Tácio.

Depois disso, tendo terminado o combate entre eles, os reis armados estão diante do altar de Júpiter e seguram as taças, unem-se em alianças, tendo sacrificado uma porca.

Haud procul inde citae Mettum in diuersa quadrigael distulerant (at tu dictis, Albane, maneres!)/ raptabatque uiri mendacis uiscera Tullus/ per siluam et sparsis rorabant sanguine uepres. [645]

Não longe, quadrigas velozes, em sentido contrário, dilaceram Meto (se tu, Albano, não descumprisses tua palavra!). E Tulo arrebata as vísceras do homem mendaz pela floresta, os espinheiros escorrem cobertos de sangue.

Nec non Tarquinium eiectum Porsenna iubebat/ accipere ingentique urbem obsidione premebat;/ Aeneadae in ferrum pro libertate ruebant./ Illum indignanti similem similemque minanti / aspiceres, pontem auderet quia uellere Cocles, [650]/ et fluuium uinclis innaret Cloelia ruptis.

Ali, Porsena ordena que se hospede o exilado Tarquínio e oprime a cidade com forte cerco; os Enéadas lançam-se ao ferro em nome da liberdade.

\footnotetext{
95 Adotamos o termo "parida" em razão da dificuldade de encontrar um termo mais próprio à tradução, portanto, acatamos a tradição da tradução da Eneida, pois C. A. Nunes, José Victorino Barreto Feio e Odorico Mendes adotaram este termo. Ainda assim, a tradução confere certa ambiguidade ao texto e não transmite, verdadeiramente, a idéia de "fetam" - a loba tinha acabado de parir, por isso ela era capaz de amamentar os meninos.
} 
Ele parece indignado e ameaçador porque Cocles ousara destruir a ponte e Clélia, tendo quebrado os grilhões, atravessara o rio a nado.

In summo custos Tarpeiae Manlius arcis/ stabat pro templo et Capitolia celsa tenebat,/ Romuleoque recens horrebat regia culmo./ Atque hic auratis uolitans argenteus anser [655]/ porticibus Gallos in limine adesse canebat;

O guardião Mânlio permanece em pé, no cume da rocha Tarpeia, nos arcos diante do templo e guarda o excelso Capitólio, a nova morada régia de Rômulo estremecia.

E ali o ganso argênteo, voando nos pórticos dourados, anuncia os gauleses que chegam à entrada.

Galli per dumos aderant arcemque tenebant,/ defensi tenebris et dono noctis opacae:/ aurea caesaries ollis atque aurea uestis,/ uirgatis lucent sagulis, tum lactea colla [660]/ auro innectuntur, duo quisque Alpina coruscant/ gaesa manu, scutis protecti corpora longis.

Os gauleses aproximam-se entre as sarças e quase tomam a cidadela, protegidos pelas trevas e pela noite opaca oferecida. Neles, as douradas vestes e os cabelos dourados; eles brilham por causa dos mantos listrados; e cinge áureo colar os cândidos colos; cada um agitava dois dardos gauleses na mão e os corpos eram protegidos por longos escudos.

Hic exsultantis Salios nudosque Lupercos / lanigerosque apices et lapsa ancilia caelo/ extuderat; castae ducebant sacra per urbem [665] pilentis matres in mollibus. Hinc procul addit/ Tartareas etiam sedes, alta ostia Ditis,/ et scelerum poenas et te, Catilina, minacil pendentem scopulo Furiarumque ora trementem,

Aqui, forjou os sálios a dançar, os lupercos despidos, os penachos de lã e também os escudos caídos do céu; as castas matronas levam objetos sagrados pela cidade em propícios pilentos.

Mais ao longe, acrescentou também as moradas do Tártaro, as poderosas portas de Dite e as punições dos criminosos, e tu, Catilina, suspenso numa terrível rocha e tremendo das bocas das Fúrias.

secretosque pios, his dantem iura Catonem. [670] Haec inter tumidi late maris ibat imago/ aurea, sed fluctu spumabant caerula cano, / et circum argento clari delphines in orbem / aequora uerrebant caudis aestumque secabant.

Os honrados estão em outra parte, aos quais Catão administra as leis. Em meio a estes eventos, a dourada imagem do mar violento estende-se ao longe, mas as águas espumam em encanecida onda; golfinhos radiantes cor de prata, em círculo, com as caudas agitam as águas e cortam o agitado mar. 
In medio classis aeratas, Actia bella, [675]/ cernere erat, totumque instructo Marte uideres / feruere Leucaten auroque effulgere fluctus. / Hinc Augustus agens Italos in proelia Caesar / cum patribus populoque, penatibus et magnis dis, / stans celsa in puppi, geminas cui tempora flammas [680]/ laeta uomunt patriumque aperitur uertice sidus.

No meio, vêem-se as frotas de bronze, as guerras de Ácio e verias o Leucate inteiro ferver, de acordo com a instrução de Marte, e as ondas brilharem a ouro.

Aqui, César Augusto conduzindo os ítalos na peleja, com os senadores, o povo, os penates e poderosos deuses, altaneiro na popa; de suas venturosas têmporas saem chamas gêmeas e o astro paterno manifesta-se sobre a cabeça.

Parte alia uentis et dis Agrippa secundis/ arduos agmen agens; cui, belli insigne superbum,/ tempora nauali fulgent rostrata corona./ Hinc ope barbarica uariisque Antonius armis [685]/ uictor ab Aurorae populis et litore rubro,/ Aegyptum uirisque Orientis et ultima secum / Bactra vehit; sequiturque (nefas) Aegyptia coniunx.

N'outra parte está Agripa, favorecido pelos ventos e deuses, altivo, conduz o batalhão; ao qual brilha a fronte com a rostral coroa marítima - distinção soberba da guerra.

Aqui, Antônio, com auxílio bárbaro e várias armas, vencedor sobre os povos da Aurora e do Mar Vermelho, traz consigo as forças do Oriente, a Báctria extrema e também o Egito; e (oh vergonha!) a esposa egípcia o acompanha.

Vna omnes ruere ac totum spumare reductis/ conuolsum remis rostrisque tridentibus aequor. [690]/ Alta petunt; pelago credas innare reuolsas/ Cycladas aut montis concurrere montibus altos:/ tanta mole uiri turritis puppibus instant.

Todos derrubam a um só tempo e todo o mar espuma cortado pelas remadas e pelos tridentes do esporão do navio.

Eles chegam ao mar alto: julgarás que as Cícladas, deslocadas do fundo, nadam, ou que as altas montanhas lutam contra montanhas: homens de tão grande estatura ameaçam nas torres das embarcações!

Stuppea flamma manu telisque uolatile ferrum / spargitur, arua noua Neptunia caede rubescunt. [695]/ Regina in mediis patrio uocat agmina sistro / necdum etiam geminos a tergo respicit anguis.

A chama de estopa arremessada com a mão e o ferro volátil é lançado, os campos netúnios tingiam-se de fresco sangue.

Em meio a isso, a rainha exorta seus batalhões com o sistro paterno, e ainda não vê as duas serpentes às suas costas. 
Niligenumque ${ }^{96}$ deum monstra et latrator Anubis / contra Neptunum et Venerem contraque Mineruam/ tela tenent. Saeuit medio in certamine Mauors [700]/ caelatus ferro tristesque ex aethere Dirae/ et scissa gaudens uadit Discordia palla,/ quam cum sanguineo sequitur Bellona flagello.

Monstruosos deuses egípcios e o ladrador Anúbis lançam golpes contra Netuno, Vênus e Minerva. No meio da batalha, Marte, ornado no ferro, enfurece-se e, nos céus, estão as Fúrias medonhas e a Discórdia satisfeita marcha com o manto rasgado, seguida por Belona com o flagelo ensanguentado.

Actius haec cernens arcum intendebat Apollo / desuper: omnis eo terrore Aegyptus et Indi, [705] omnis Arabs, omnes uertebant terga Sabaei. / Ipsa uidebatur uentis regina uocatis / uela dare et laxos iam iamque immitere funis.

De cima do Ácio, Apolo, divisando tais coisas, armava o arco: todos tomados de terror, o Egito, os indos, os árabes e os sabeus recuavam.

A própria rainha parecia, tendo chamado os ventos, dar as velas e imediatamente desprender os frouxos panos.

Illam inter caedes pallentem morte futural fecerat ignipotens undis et Iapyge ferri, [710]/ contra autem magno maerentem corpore Nilum/ pandentemque sinus et tota ueste uocantem/ caeruleum in gremium latebrosaque flumina uictos.

O Ignipotente a fez pálida por medo da morte futura, pelas ondas e pelo vento de Iápige durante o morticínio.

Em frente, o Nilo corpulento, lamentando-se e abrindo seus seios e com toda a veste chamando os vencidos para seu colo cerúleo e para os latebrosos rios.

At Caesar triplici inuectus Romana triumpho/ moenia dis Italis, uotum immortale, sacrabat, [715] maxima ter centum totam delubra per urbem./ Laetitia ludisque uiae plausuque fremebant; / omnibus in templis matrum chorus, omnibus arae;/ ante aras terram caesi strauere iuuenci.

Ao passo que César é levado aos muros romanos, em tríplice triunfo, e consagra o voto imortal aos deuses ítalos, trezentos templos, muitíssimo elevados, por toda a cidade.

As ruas ressoam com alegria, jogos e aplausos; há um coro de matronas em todos os templos, em todos os altares; diante das aras, alastram os novilhos imolados pelo chão.

96 Na edição da Livraria Cruz (1945), o termo latino é "omnigenum" no lugar de "niligenum", semanticamente o primeiro está mais próximo da tradução de C. A. Nunes ("toda a caterva") e de O. Mendes ("onígenos"), mas preferimos seguir a edição da Belles Lettres. 
Ipse sedens niueo candentis limine Phoebi [720] / dona recognoscit populorum aptatque superbis / postibus; incedunt ${ }^{97}$ uictae longo ordine gentes, / quam uariae linguis, habitu tam uestis et armis./ Hic Nomandum genus et discinctos Mulciber Afros,

O próprio César, sentando-se na nívea porta de Febo incandescente, examina os presentes de povos e os pendura nos soberbos umbrais; os povos vencidos numa longa fileira desfilam, tão variados nas línguas, no costume das vestes e nas armas. Aqui, Mulcíbero representou a raça dos nômades e os distintos afros,

hic Lelegas Carasque, sagittiferosque Gelonos [725] / finxerat; Euphrates ibat iam mollior undis / extremique hominum Morini, Rhenusque bicornis / indomitique Dahae et pontem indignatus Araxes.

acolá, representou os lélegas, os cários e os gelonos, armados de flecha; o Eufrates já flui com ondas mais brandas, os morinos, últimos dos habitantes, e o Reno bicorne. Os indomáveis dahas e o Araxes, que não gosta de pontes.

$* * *$

O escudo de Eneias merece destaque: essa longa écfrase da Eneida serve para corroborar as características observadas nas demais que, de menor extensão, não confiram talvez tanto destaque aos elementos constitutivos da écfrase. Além disso, a écfrase do escudo é um tópico que possibilita estabelecer relação com outros textos, tais como: a Ilíada de Homero, Os sete contra Tebas de Ésquilo e o Escudo de Héracles atribuído a Hesíodo.

O tempo verbal de maior predominância é o pretérito imperfeito do indicativo, seguido muito de perto pelo presente do indicativo e pelas formas nominais do particípio presente, particípio pretérito e infinitivo presente.

O tempo futuro não aparece em toda a passagem - com exceção da forma nominal "futura" (v.709) - o que pode parecer estranho, em razão do conteúdo da narrativa relatar fatos futuros. Presume-se que o emprego de tempos no pretérito contribui para dar maior veracidade aos fatos, porque com certeza eles acontecerão e já são inseridos aqui como parte da história romana.

Notamos que o uso do tempo pretérito imperfeito predomina na menção às ações das personagens: stabant et... iungebant (v.641), raptabat (v. 644), rorabant (v.645), iubebat (v. 646), ruebant (v. 648), tenebat (v. 653), horrebat (v. 654), canebat (v. 656), uerrebant, secabant (v. 674), entre outros. A impressão transmitida é que, conforme vemos as imagens, as personagens estão ainda executando as ações mencionadas.

\footnotetext{
${ }^{97} \mathrm{Na}$ mesma edição citada na nota anterior, o verbo adotado é o incendo (“incendunt”) que não só lembra o epíteto de Apolo linguisticamente como também remete ao mesmo campo semântico de "candentis".
} 
Os eventos sucedem-se muito rapidamente, provavelmente para que o leitor não disperse sua atenção, pois assim ele se prende à dinâmica da narração.

As formas participiais servem para entrever uma ação em meio à imagem que não é narrada na cena descrita, como na referência ao rapto das Sabinas (raptas Sabinas), no verso 635, e ao fim do combate (inter se posito certamine), verso 639.

A partir do verso 691, a frequência do imperfeito diminui para dar lugar ao presente, introduzido pelo verbo "credas" (segunda pessoa do presente do subjuntivo), isso ocorre no momento em que se inicia a grande batalha. $\mathrm{O}$ significado do verbo deixa entrever que há uma narração subentendida na imagem que segue, sem que ela esteja realmente representada pictoricamente no objeto. Ainda nessa passagem, Virgílio utiliza símiles para demonstrar a grandiosidade da batalha: um compara o efeito dos navios no mar com as Cícladas nadando; o outro, a luta dos homens ao choque de duas grandes montanhas, tamanha é a força daqueles.

As expressões que remetem à coloração são em alguns momentos indicadas pelo material do objeto ou pela imagem do sangue, como também se observa nas outras écfrases do poema: sanguine (v.645), argenteus anser (v.655), auera uestis (v.659), auro (v.661), imago aurea (v.671-72), argento clari delphines (v.673), classis aeratas (v.675), auroque effulgere fluctus (v.677), caede rubescunt (v.695), cum sanguineo flagello (v.703).

Algumas vezes, simplesmente temos a indicação da cor: uiridi... in antro (v.630); lactea colla (v.660); fluctu ... caerula cano (v.672); litore rubro (v.686); illam ... pallentem (v.709); caeraleum in gremium (v.713); niueo limine (v.720).

A referência à escuridão da noite (v.658) possibilita contrapor as cenas que ocorrem durante o dia, cercadas de elementos que lembram a luz. Nessa mesma imagem, os mantos são descritos como listrados: "uirgatis lucent sagulis" (v.660) e sabemos que o restante da vestimenta é dourado, esse detalhe impulsiona o leitor a imaginar a cena mais fortemente.

A imagem das chamas permite imaginar a aparência do fogo que elas apresentam: geminas flammas (v.680), stuppea flamma (v.694); o mesmo ocorre com o verbo "candentis" (v.720), constituindo uma referência à divindade Apolo. Ao celebrar a vitória, Otávio observa os presentes dos povos vencidos no templo de "Febo incandescente", de modo que estes simbolizem os próprios povos, que ganham vida diante da visualização dos presentes. Nessa passagem, o poeta adotou o verbo "incedo" no presente do indicativo que lembra linguisticamente o epíteto com o qual o deus é 
mencionado: candentis Phoebi. O epíteto nos remete à luz, apropriado para Apolo ou Febo, recordando ao leitor de que os eventos são iluminados para que os possamos ver.

Notamos, a partir do material citado, que a coloração dourada é muito comum em todo o poema, isso não só nos remete ao meio material, mas lembra a luz do sol; sobretudo quando o mar, cenário da batalha de Ácio, está dourado, refletindo a luz solar. Inevitavelmente, relacionamos essa referência ao deus Apolo, que aparece no poema auxiliando os romanos durante a batalha.

Outro elemento colabora para colorir a imagem: o verbo "spumare" (v.689) lembra a cor branca das espumas.

A matéria-prima utilizada, variável de acordo com as imagens forjadas, aparece com frequência, lembrando que o predomínio da coloração dourada já é um indicativo de que o escudo teria sido forjado em ouro. No princípio, o poeta informa que a armadura é de ouro e âmbar, mas sem especificação em qual dos dois o escudo teria sido forjado. Independente disso, outros materiais são mencionados como constituintes de algumas figuras; alguns casos já mencionamos acima, a respeito da coloração: argenteus anser (v.655), auratis porticibus (v.655-6), aureae caesaries (v.659), aurea uestis (v. 659), lanigerosque apices (v.664), maris imago aurea (v.671-2), argento...delphines (v.673), classis aeratas (v.675), auroque effulgere fluctus (v.677), uolatile ferrum (v.694), Mauors caelatus ferro (v.700-1).

A descrição em determinadas cenas é tão detalhada, constituída pelos elementos supracitados, que as ações parecem realmente estar ocorrendo. A loba, acariciando os meninos alternadamente enquanto os mesmos alimentavam-se nela, remonta à fundação romana por meio da representação imagética do mito. A travessia dos golfinhos pelo mar não é apenas um quadro estático, a imagem é mais vivaz, pois eles não apenas atravessam, mas agitam o mar, cortando-o com sua passagem - a sensação é de vermos as águas agitadas e não apenas a superfície imóvel de uma pintura.

Descreve-se a batalha de Ácio, a partir do verso 675, com os principais acontecimentos, ainda que rapidamente, mas de maneira que as ações importantes para o andamento da batalha estejam implícitas.

De acordo com a tradição da Segunda Sofística, Homero teria fornecido inúmeros exemplos de écfrase, dentre os quais se destaca o escudo de Aquiles, no canto XVIII da Ilíada.

Virgílio emulou o poema homérico ao fazer para Eneias um escudo com as imagens gravadas, assim como ocorre no escudo de Aquiles. A princípio, percebemos 
algumas semelhanças, tais como sua fabricação, operada pela mesma divindade Hefesto, para os gregos, ou Vulcano, para os romanos; as armas são feitas por esse deus a pedido da mãe dos heróis; e ambos usarão o escudo na batalha decisiva da trama.

Devemos, no entanto, ser cuidadosos ao compará-los, pois há nessas duas ocorrências da écfrase um grande contraste: o escudo de Aquiles é descrito durante sua fabricação, não temos o objeto pronto diante de nós, Hefesto forja diante do leitor as imagens que ganham vida ao mesmo tempo em que são gravadas no escudo. Desse modo, o efeito de sentido produzido é o de visualizar os fatos como uma sequência de ações, ou seja, não constitui simples descrição, pois temos uma narrativa inserida nas imagens.

Lembremos a distinção que Lessing faz entre poeta e pintor, cada um atuando em um domínio - ao poeta cabe a progressão temporal. Afinal, se considerássemos a descrição em seus detalhes, um escudo não seria suficiente para tantas imagens; a narração, contudo, não é limitada pelo espaço do objeto, uma mesma cena implica outros acontecimentos.

Lessing, em seu Laocoonte, $\mathrm{XIX}^{98}$, demonstra que já houve a tentativa de isolar as imagens descritas no escudo de Aquiles, porém, o resultado é improvável, resultaria num escudo excessivamente grande para caber também as ações implícitas. Há ainda outro problema, o poeta descreve o escudo como objeto fictício, portanto, não se submete às regras da elaboração de uma obra imagética, mas ao decoro poético portanto, o escudo transcrito seria um objeto visualmente incoerente.

Aquiles, irado, não percebe o conteúdo das imagens, o herói admira as armas divinas e vai para a luta, ignorando o conteúdo do escudo. Nisso difere da Eneida, Eneias admira as armas e exulta diante das imagens do escudo.

A escolha do escudo como objeto da écfrase na Ilíada é coerente com o ambiente épico do poema, ainda que mensagens de paz sejam veiculadas nele. A escolha do escudo na Eneida parece servir à "ideologia" veiculada nas artes do período de Augusto, pois o escudo indica proteção na guerra, ao passo que, no poema, esse artefato indica o caminho que levará o povo à paz, uma vez que a narração se

\footnotetext{
98 "Para se contrapor à objeção principal que afirma que Homero encheu o escudo com um monte de figuras para as quais seria impossível haver espaço ali, Boivin empreendeu de fazer desenhá-lo seguindo a medida necessária." (pp.221) - Cf. nota 89. O artigo de TAPLIN, O. "The Shield of Achilles within the 'Iliad”'. In: Greece \& Rome. 1980, vol.27, pp.1-21, traz uma possível divisão das imagens no escudo de Aquiles.
} 
encaminha para a vitória de Augusto. Mais adiante veremos outros aspectos que corroboram a propaganda política inserida no escudo.

No escudo de Eneias a produção não ganha destaque, a descrição do escudo é feita pelo próprio herói no momento em que recebe as armas. Ainda que a écfrase seja estruturada como descrição, é necessário que haja um ponto de vista para situar as imagens numa certa ordem, para que possam ser compreendidas e apreendidas pelo leitor. No caso da Ilíada, o ponto de vista é o do poeta, na Eneida, é o do herói, portanto, vemos aquilo que Eneias consegue enxergar no escudo ${ }^{99}$.

Assim como o discurso de Anquises no livro VI, o conteúdo do escudo é profético, mas a profecia nele contida tem como porta-voz o herói do poema. As imagens, gradualmente, narram a história romana e seus grandes feitos; reafirma-se o futuro da estirpe de Eneias, agora, porém, com a mediação de um objeto divino - temos novamente a afirmação do fatum de Eneias como o responsável pela origem romana, tese que vemos reiteradamente desde o primeiro canto, para justificar a fuga do herói da guerra de Troia.

Antes mesmo da descrição do objeto temos a expressão "non enarrabile textum" (v. 625) que antecipa a tentativa de representar pelo meio verbal o que pertence a outro gênero de representação. Situada logo no começo, tal expressão chama a atenção para a capacidade mimética da linguagem e, ao mesmo tempo, cria uma expectativa muito maior no leitor, curioso em saber qual imagem não se pode traduzir em palavras e, apesar disso, o poeta vai fazê-lo.

O emprego de verbos do campo semântico da fabricação é frequente nas descrições de objetos, característica que também nos remete ao meio da representação. Também notamos este aspecto no escudo de Aquiles, mas não ocorre muito frequentemente, por exemplo, na écfrase do canto I, nas paredes do templo, onde desconhecemos o pintor. Sabemos que o escudo foi forjado por Vulcano, há um artífice que não deve ser esquecido, pois é justamente a divindade do artista que confere maior prestígio e veracidade ao discurso.

Ao introduzir a descrição do escudo, temos o verbo "fecerat" (v.628) para indicar o que Vulcano colocara no escudo; o mesmo verbo se repete nos versos 630 e 710. Mais adiante, o verbo "addiderat" (v. 637) retoma a presença do artífice, esse

\footnotetext{
${ }^{99}$ MARTINS, P. “Enéias se reconhece”. In: Letras Clássicas. São Paulo: Humanitas. 2005, n5, pp.14357.
} 
verbo reaparece no verso 666, sob o tempo presente do indicativo (addit). Outro verbo é empregado com o sentido de "forjar": extuderat (v.665).

Outra característica que podemos destacar do texto é o uso de expressões adverbiais que ora localizam as imagens no espaço do escudo, ora ordenam a disposição para que haja uma sequência coerente, são exemplos disso: illic (v.626 e 628), nec procul hinc (v. 635), haud procul (v.642), hic (v. 655/ 663/ 724-5), hinc procul (v. 666), in medio (v.675), hinc (v. 678/ 685), parte alia (v. 682), desuper (v. 705). As conjunções como et, usual nos textos latinos, e autem (v. 711) servem como ligação entre as sentenças que não são retomadas por um advérbio e também contribuem para a estruturação espacial das imagens.

Além da localização das imagens no escudo, elementos são inseridos em algum local da narrativa mencionada. Por exemplo: quando Rômulo e Tácio estão diante do altar (“ante aram", v. 640); Tulo arrebata Meto pela floresta (“per siluam”, v. 644-45); Mânlio, na sua posição de vigia, permanece em pé, no cume da rocha Tarpeia, nos arcos diante do templo ("In summo custos Tarpeiae [...] arcis / stabat pro templo", v. 652-3); o ganso voando nos pórticos ("porticibus", v.655-56); os gauleses entre as sarças ("per dumos", v. 657); Cleópatra no meio dos acontecimentos da batalha (“in mediis", v.696); César consagra templos pela cidade aos deuses ("per urbem", v.716); a celebração do triunfo de César pelas matronas em todos os templos, em todos os altares e também diante das aras, (“omnibus in templis matrum chorus, omnibus arae”, v. 718); os novilhos imolados pelo chão ("ante aras terram caesi strauere iuuenci”, v.719); César pendura os presentes dos povos vencidos nos umbrais ("postibus", v.722).

Algumas locuções adverbiais podem indicar o curso temporal: in ordine (v.629), post idem (v.639), iam iamque (v.708). A expressão "in ordine”, segundo o comentário de Gransden ${ }^{100}$, tem a mesma função da expressão similar “ex ordine" (I, 456), ambas significam "na sequência". Porém, dado o conteúdo da descrição, transmitem certa ambiguidade, pois indicam ordem cronológica; entretanto, no caso do escudo, não pode haver linearidade porque o olho do espectador converge naturalmente para o centro do objeto, para onde se direcionaria o fato mais recente e importante. Para Gransden a expressão conduz para o desvelamento da história romana.

A preposição "post", listada acima, ainda de acordo com Gransden, é um conectivo temporal que substitui outros conectivos espaciais próximos a essa passagem,

${ }^{100}$ GRANSDEN, K.W. Virgil Aeneid. Book VIII. Cambridge: Cambridge University Press. 1999. 
portanto, "post" encerra também a concepção de espaço - indica tanto a sequência temporal de algo que sucede o combate mencionado antes, como a distribuição da imagem no espaço do escudo.

A locução adverbial "iam iamque" enfatiza a pressa da rainha no momento da fuga; o comentarista Gransden destaca nesse verso o emprego de hysteron proteron, ou seja, demonstra duas ações transcorrendo simultaneamente, a locução assim empregada ressalta tal simultaneidade na fuga da rainha, pois a vemos fazer todas as ações necessárias para empreendê-la.

Temos no escudo a narração que começa pela fundação, com os meninos sendo amamentados pela loba; desde já se desenha o éthos dos romanos, representados aqui pelos meninos "corajosos".

Em seguida, narra-se outro fato lendário que remonta às origens da estirpe romana: o rapto das Sabinas, importante acontecimento para o povoamento de Roma. Em poucos versos Virgílio resume o episódio, embora o curso dos acontecimentos seja rápido, eventos simbólicos são citados para remeter à lenda.

Uma das imagens é introduzida pelo verbo "aspiceres" (v.650), segunda pessoa do singular, no imperfeito do subjuntivo, que se dirige ao leitor transmitindo a ideia de que ele verá algo que acaba de acontecer. Ainda nessa parte, quando se apresenta o conflito com Porsena, explicam-se as causas da sua raiva, mencionando-se dois fatos que ocorreram anteriormente; não se introduzem as imagens que representam Cocles destruindo a ponte ou Clélia atravessando o rio, na verdade, são ações que estão implícitas numa única imagem - a raiva de Porsena.

Esse aspecto contraria o que Lessing afirma a respeito do escudo de Eneias: para ele a pintura permanece parada, enquanto as imagens do escudo de Aquiles deixam subentender muitos outros acontecimentos. Segundo Lessing, Virgílio valoriza apenas os ornamentos; contudo, esse argumento parece fraco já que toda a descrição do escudo apresenta aspectos que vão além da mera ornamentação, cada ornamento tem uma determinada função na écfrase. As imagens no escudo de Eneias também deixam entrever outras ações, conferindo movimento à descrição.

Os acontecimentos bélicos são objetos comuns da descrição, como vimos nos Progymnásmata, por essa razão, os conflitos ganham destaque no escudo. A guerra é ressaltada para mostrar o lado vencedor, que aqui é sempre o dos romanos. A narração caminha para a batalha de Ácio a partir do verso 675, decisiva para a consolidação do poder de Augusto, por isso está localizada no meio do escudo e também praticamente 
no meio da écfrase, para representar o que seria o acontecimento central da história romana ${ }^{101}$. Prova disso é que a écfrase se volta a partir daí só para a descrição da batalha, a vitória de Augusto e sua celebração, afinal, as festas também são típicas da écfrase.

As guerras são então mostradas como instrumento necessário para a conquista do poder, em razão disso, a violência dos acontecimentos é transmitida constantemente com termos que remetem à coloração do sangue em meio às carnificinas: os espinheiros cobertos de sangue; os campos netúnios tingidos de sangue; o flagelo ensanguentado.

Augusto é apresentado como uma figura divina, saem-lhe das têmporas chamas que nos remetem à luz, novamente somos inseridos no universo do deus Apolo, que está do lado de Augusto. Gurval ${ }^{102}$, na análise do cometa que aparece nas biografias de César, associa essa passagem da Eneida com o mito em torno da morte de César, pois a descrição das chamas pode remeter ao cometa, mas não de forma explícita, pois essa comparação ocorre em outras partes do poema de modo mais evidente.

Sérvio, em seus Comentários da Eneida, esclarece a respeito do verso 681 que Augusto colocava uma estrela em seu próprio elmo para comparar-se a seu ancestral César, cuja estátua recebia uma estrela sobre a cabeça.

No momento seguinte, surge Antônio, retratado como alguém poderoso por meio da enumeração dos povos vencidos, mas que desonrou seu próprio povo por causa da esposa egípcia; torna-se um inimigo vencido por Augusto.

A enumeração é comum nas descrições, sobretudo nesse contexto bélico, é um recurso muito adotado nessa écfrase para valorizar e amplificar os fatos. Ela ocorre no conflito com os gauleses, na batalha de Ácio quando se dá a luta entre os deuses, no ataque de Apolo aos inimigos e no desfile dos povos vencidos.

O efeito produzido deleita, uma vez que o leitor que se transforma em espectador. Função que prova estar de acordo com a teoria concernente ao assunto, visto que a écfrase está especialmente associada ao discurso epidítico, cuja finalidade pricipal é deleitar.

No verso 643 do canto VIII, temos uma parentética que utiliza a apóstrofe, que consiste em dirigir a palavra a outra pessoa que não seja o público para o qual se fala até então. Esse procedimento tem um efeito patético, pois notamos que o narrador se mostra

${ }^{101}$ BARTSCH, S. "Ars and the Man: The Politics of Art in Virgil's Aeneid". In: Classical Philology. 1998, vol.93, pp.322-42.

${ }^{102}$ GURVAL, R.A. "Caesar's Comet: The Politics and Poetics of an Augustan Myth". In: Memoirs of the American Academy in Rome. 1997, vol. 42, pp. 39-71. 
indignado com o fato, além, é claro, de surpreender com a mudança inesperada. Mais uma vez, o meio de representação do objeto é lembrado, mas isso não interfere no objetivo da figura, ao contrário, auxilia na comoção do leitor, pois a emoção guia o leitor para ingressar no mundo descrito. Temos, então, outra característica da écfrase, ela abandona a descrição material e trata predominantemente do referente - assim sucede com o escudo de Eneias que oscila entre a pormenorização do aspecto material e o conteúdo histórico.

Podemos relacionar essa passagem com o cumprimento de outra função retórica que é o docere. Virgílio nos propõe a emulação de um modelo homérico - a adoção do escudo para veículo da écfrase - o leitor, tendo tomado conhecimento dessa emulação, assimila melhor o mecanismo da écfrase, uma vez que recebe dois exemplos ao mesmo tempo, um deles pertencente à poesia homérica, considerada tradicionalmente o modelo superior de poesia épica. Devemos lembrar que não é esse o propósito da écfrase, pois pretende acima de tudo mouere e delectare, mesmo assim, os recursos retóricos são trabalhados na estrutura da obra e de acordo com os objetivos que são variáveis.

Há outra parte à qual se pode atribuir o docere junto ao mouere: uma imagem aterrorizante é descrita para representar Catilina pagando por seus crimes, suspenso numa rocha, quase caindo no Tártaro. Em seguida, temos Catão que, por ser justo, separa os honestos. Cria-se um quadro moral que nos dá, de um lado, um representante do vício, e do outro, um exemplo de virtude.

Durante a batalha, a rainha Cleópatra não pode ver atrás de si as serpentes (necdum etiam geminos a tergo respicit anguis - v.697), mas o leitor pode enxergar tudo o que o herói vê - vemos com os olhos de Enéias.

O uso do escudo como objeto da écfrase é estratégico nos poemas épicos; no caso da Ilíada, o escudo é uma arma de defesa para o herói. Embora digressiva, a écfrase serve para confirmar o dever do herói de ir à guerra e lutar pelo seu povo. $\mathrm{O}$ conteúdo gravado no escudo intercala momentos de paz e de luta que, no contexto, associa-se ao povo e ao herói.

Na Eneida, o instrumento de proteção de Eneias vai ajudá-lo a vencer a batalha decisiva para que possa estabelecer um domínio que futuramente será o império romano, erigido por seus descendentes. O escudo profetiza para Eneias o destino de sua estirpe, que será a dos romanos, e como exemplo maior dessa linhagem temos Augusto, imperando sozinho depois da vitória, tal como ocorre com Eneias, que seguirá para a 
principal batalha levando consigo o escudo e a responsabilidade de cumprir tais profecias.

O emprego da écfrase, como já afirmamos, não se restringe a gêneros específicos, na tragédia Os Sete contra Tebas a figura é utilizada para descrever os escudos dos guerreiros que ameaçam as entradas da cidade. Embora aplicada no gênero trágico, em razão do objeto utilizado a narrativa tem certo tom épico. Considerando a doutrina aristotélica que insere a Tragédia entre os gêneros que descrevem homens superiores, pode-se dizer que o discurso descritivo é aqui empregado para elevar as condições de cada guerreiro, visto que a descrição das armaduras de cada um recebe destaque.

Alguns escudos apresentam uma inscrição inserida na descrição verbal da imagem, ressaltando a intersecção entre o discurso verbal e visual.

A matéria prima do escudo é mencionada, ainda que implicitamente, pois em alguns o material da armadura subentende o do escudo, demonstrando sua grandiosidade $\mathrm{da}^{103}$ :

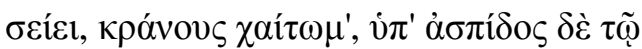

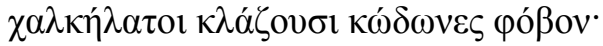

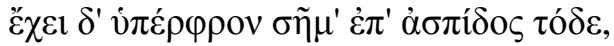

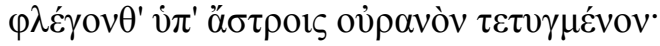

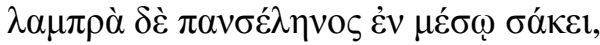

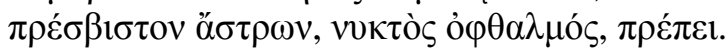

[...] o penacho do capacete e sob o escudo/ soam apavorantes guizos de bronze. Traz/ no escudo emblema altaneiro, estende-se/ o céu, marchetado de estrelas, luminoso/ fulge no centro da égide o fulgor do plenilúnio. / Entre os astros esplende a lua, olho da noite. (v. 385-90)

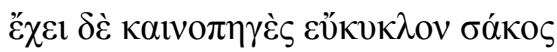

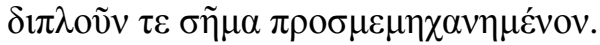

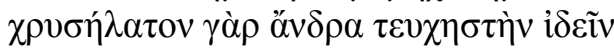

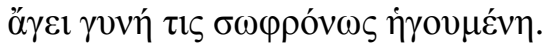

Porta um recém-forjado escudo circular, / provido de emblema duplo, trabalhado com arte. / Exibe um homem talhado em ouro, armado, conduzido por uma mulher serena. (v. 642-45)

\footnotetext{
103 Todas as citações da peça foram extraídas da tradução de Donaldo Schüler. Porto Alegre: L\&PM
} Editores. 2007. 
Observa-se que a luminosidade da primeira figura veiculada colabora com a enargia que se quer produzir; em outros escudos, a luminosidade é conferida pela presença do fogo nas figurações.

Em um dos escudos, o artífice é mencionado, a exemplo do que se observa em Virgílio e também em Homero:

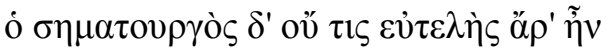

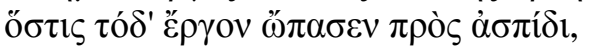

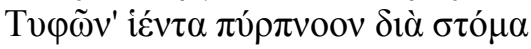

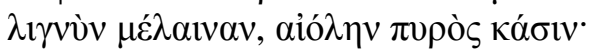

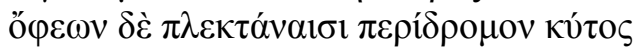

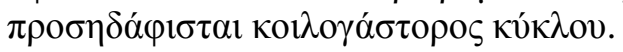 \\ “[...] Com certeza não é/ vulgar o artista que lhe gravou o emblema. / \\ na égide: Tifão, que expele fogo pela boca,/ jato envolto em fumo \\ negro, irmão das/ chamas inquietas. Serpentes enredadas/ curvam-se \\ na borda do côncavo escudo." (v. 491-96)
}

Nessa peça, contudo, o escudo do sexto guerreiro chama a atenção pela ausência de imagem:

“[...] Empunhava tranquilo um escudo de bronze/ maciço, em cujo centro não se via emblema algum. Não/ queria parecer o melhor, queria sê-lo. [...]" (v. 590-92).

É justamente esse o único dos guerreiros descrito a quem até mesmo Eteócles considera um homem honrado, mas que lamentavelmente está entre os ímpios.

Os escudos d'Os Sete contra Tebas são representativos na história, uma vez que representam a batalha da tragédia e, por essa razão, as imagens são muito significativas no contexto, veiculando exortações e também figuras de divindades monstruosas. A extensão não lhes permite conferir progressão às imagens, contudo, são detalhadas na medida para permitir o efeito da enargia.

O Escudo de Héracles é um poema grego composto em versos hexamétricos que apresenta também uma ocorrência da écfrase em escudo (v.140-320). A datação do poema é imprecisa, provavelmente do século VI a.C., atribuído a Hesíodo, mas há dúvidas a respeito da autoria. Algumas expressões e recursos aparecem tanto nesse poema como na Ilíada e, a partir disso, é possível estabelecer alguns tópicos, uma vez que observamos a semelhança com elementos presentes não apenas na descrição do escudo de Eneias como também em outros tipos de descrição.

O artífice do escudo de Héracles é o mesmo da Ilíada - o deus Hefesto que é três vezes lembrado durante a écfrase. A referência aos materiais utilizados é recorrente, tais 
como ${ }^{104}$ : "No meio era de aço Pavor não dizível” (v.145); "Aí estavam céleres cavalos de Ares hirsuto,/ áureos [...]” (v.190-91); “[...] feito com o derretido estanho" (v.206); "argênteos delfins [...]" (v.212), etc.

A enumeração de personagens é frequente, pois o escudo veicula imagens bélicas e os apresenta como um catálogo de grandes guerreiros.

Algumas passagens são incrivelmente semelhantes à écfrase da Ilíada, aspecto que leva alguns teóricos a acreditar que haveria interpolação ${ }^{105}$ nesta última com excertos do poema pseudo-hesiódico:

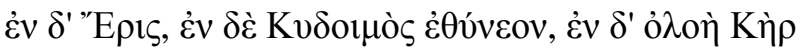

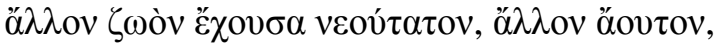

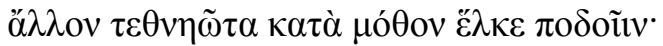

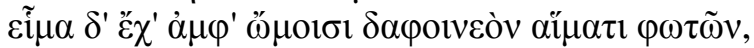

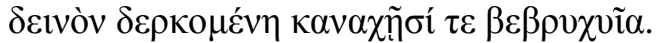

Aí Rixa e ali Tumulto correm, e a funesta Cisão/ pega um vivo recémferido, pega outro não ferido, / e puxa pelos pés ainda outro, morto ao lutar na peleja./ Traz nos ombros vestes fulvas de sangue viril [...] (Escudo de Heracles, v.156-59)

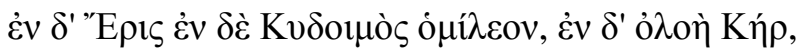

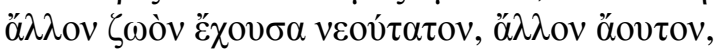

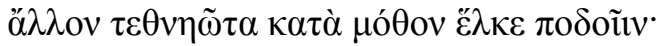

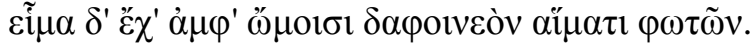

Via-se a fera Discórdia, o Tumulto e a funesta e inamável/ Parca, que havia agarrado a um ferido, a um guerreiro ainda ileso, / e pelos pés arrastava a um terceiro, que a vida perdera./ Dos ombros pendem-lhe as vestes manchadas de sangue dos homens.

(Ilíada, XVIII, v.535-38)

saeuit medio in certamine Mauors caelatus ferro, tristesque ex aethere Dirae, et scissa gaudens uadit Discordia palla, quam cum sanguineo sequitur Bellona flagello.

No meio da batalha, Marte, ornado no ferro, enfurece-se e, nos céus, estão as Fúrias medonhas e a Discórdia satisfeita marcha com o manto rasgado, seguida por Belona com o flagelo ensanguentado.

(Eneida, VIII, 700-3)

\footnotetext{
${ }^{104}$ Todas as citações foram extraídas da tradução de Jaa Torrano. In: Hypnos. 2000. Ano 5, nº6, pp.185221.

${ }^{105}$ Cf. artigo de Taplin, citado na nota 98, pp. 7.
} 
A partir do exemplo acima fica patente a relação não só temática como também lexical, pois a cena é descrita de maneira semelhante. Há outros casos ao longo do poema que podem ser equiparados à Ilíada, a partir dos quais percebemos certo parentesco, por assim dizer, também na Eneida; no entanto, é importante citar uma passagem do Escudo de Héracles que vemos presente diretamente na Eneida:

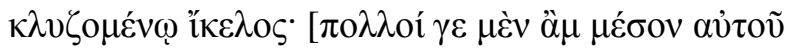

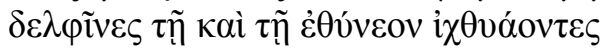

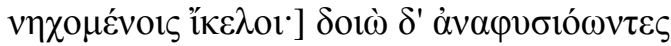

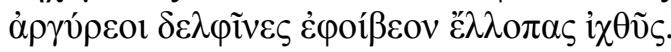

[...] parecia batido de ondas; no meio dele, muitos/ delfins aqui e ali saltitavam a pescar,/ pareciam nadar, e dois a respirarem/ argênteos delfins afugentavam mudos peixes.

(Escudo de Heracles, v.209-12)

haec inter tumidi late maris ibat imago

aurea, sed fluctu spumabant caerula cano,

et circum argento clari delphines in orbem

aequora uerrebant caudis aestumque secabant.

[...] mas as águas espumam em encanecida onda; golfinhos radiantes cor de prata, em círculo, com as caudas agitam as águas e cortam o agitado mar.

(Eneida, VIII, v.672-74)

O escudo funciona bem como veículo da écfrase, visto que seu emprego é frequente; além dos exemplos já citados, ocorre ainda na tragédia Electra de Eurípedes, na qual se descreve brevemente o escudo de Aquiles. A descrição das armas constitui uma tópica no gênero épico, portanto, é inegável que a écfrase se insere nessa tradição para incitar a visualização da descrição.

\section{O cinto de Palante $\mathrm{X}, \mathbf{4 9 5 - 5 0 0}$}

[...] Et laeuo pressit pede talia fatus [495]/ exanimem rapiens immania pondera baltei/ impressumque nefas: una sub nocte iugali/ caesa manus iuuenum foede thalamique cruenti,/ quae Clonus Eurytides multo caelauerat auro;/ quo nunc Turnus ouat spolio gaudetque potitus. [500]

[...] E pisou com o pé esquerdo o corpo, apoderando-se do admirável cinturão, tais crueldades nele gravados: numa noite nupcial, a mão morta dos jovens, os leitos cruelmente ensanguentados, o que 
Clono de Eurito insculpira no ouro; Turno agora ovaciona por causa do espólio e alegra-se de possuí-lo.

$* * *$

No canto $\mathrm{X}$ encontra-se a écfrase de menor extensão do poema, portanto, na descrição do objeto há poucas ocorrências verbias, com destaque para o perfeito. Alguns verbos evidenciam tratar-se da obra executada por alguém, enquadrando-se no critério de écfrase como descrição de obra: impressum (v.497) e caelauerat (v.499).

A écfrase aqui pertence à tradição épica de descrever as armas dos guerreiros, mas sem o destaque das outras ocorrências; o artífice não é exaltado e não foi feito por uma divindade.

Turno derrota Palante, o filho de Evandro e aliado de Eneias, e toma para si o cinto do cadáver. Nele estão gravadas imagens de um crime no leito nupcial, cena horrível que remete ao motivo da discórdia entre Turno e Eneias: o casamento com Lavínia.

Associando-se tal conteúdo com o momento de sua descrição, entendemos que a vitória pertence ao inimigo por ora, uma vez que Turno vence a batalha e os cônjuges da figura estão mortos. No entanto, o poema segue com o alerta de que o homem ignora o futuro e que Turno pagará pelo espólio.

A matéria-prima do objeto é o ouro, conforme se observa no verso 499. Como não há menção a outros materiais e tampouco a cores, o ouro indica a cor do objeto. Ao mostrar o leito como "cruenti" (v.498), imaginamos os noivos ensanguentados, parte que confere coloração à imagem e a torna mais viva, pois rompe com o material dourado.

Achamos indício de circunstância temporal - "nocte" (v.497), subentendendo o momento da ação.

Embora pequena, alguns aspectos que se mostraram presentes nessa écfrase se repetem nas demais ocorrências da Eneida. Além disso, o cinto ganha mais destaque quando descrito detalhadamente, demonstrando sua importância; afinal, é depois de contemplá-lo que Eneias, prestes a deixar seu inimigo vivo, encerra a luta enfurecido diante do objeto roubado de seu aliado. 


\section{III.2. Poema 64 de Catulo ${ }^{106}$}

Analisaremos a écfrase do poema 64 de Catulo, que constitui um epos e, para isso, é preciso observar a manifestação da poikilia, fundamental para compreender o poema. Entenda-se poikilia como a mistura de gêneros poéticos - característica herdada do helenismo pelos poetas latinos. É o que Rossi chama "legi scritte e non rispettate"107 ("leis escritas, mas não respeitadas").

Deparamo-nos, na poesia latina, com inúmeros exemplos de poemas em que se opera a poikilia, tais como Ovídio, Horácio e Catulo. Esse cruzamento entre os gêneros pode ocorrer em diversas instâncias: o metro pode pertencer a um gênero, mas a matéria ser característica de outro; variação métrica dentro de um mesmo poema; ou, ainda, uma mesma matéria apresenta objetivos distintos que caracterizam gêneros distintos (é o caso da temática amorosa, presente na Elegia e na Lírica; ou da morte, matéria típica do Epigrama e também da Elegia).

O poema 64 de Catulo é um exemplo rico no que se refere à mistura de gêneros; inicialmente, talvez salte aos olhos apenas o fato de ser, ao mesmo tempo, epílio e epitalâmio; contudo, veremos em algumas passagens, ainda que muito breves, a presença do gênero elegíaco e iâmbico também.

O poema 64, o mais extenso de Catulo, é uma composição em hexâmetro dactílico; a temática, porém, é típica do epitalâmio. O epitalâmio é uma espécie do gênero lírico que celebra as núpcias de um casal. Segundo Fócio-Proclo (Biblioteca, 239 - 321a), a definição de epitalâmio é a seguinte: um canto entoado por um coro de rapazes e moças diante do quarto nupcial dos recém-casados.

Sabe-se que era costume dos gregos e dos romanos compor cantos para os casamentos e isso se reflete na poesia. Podemos destacar Safo como um bom exemplo nesse gênero e, como sabemos da presença de Safo na poesia de Catulo, podemos dizer que ela exerceu influência sobre sua poesia no que concerne aos epitalâmios.

Devemos mencionar algumas características que são comuns nos epitalâmios, o que podemos chamar de topos do gênero ${ }^{108}$ : elogio à noiva, cuja beleza pode ser

\footnotetext{
${ }^{106}$ Essa análise é a adaptação do trabalho de conclusão da disciplina de Pós-Graduação "Lírica latina e seus gêneros confins", ministrada pelo professor João Angelo Oliva Neto. O estudo do poema foi realizado com base em tradução já existente, muito conceituada no meio acadêmico, não havendo necessidade de traduzi-lo.

${ }^{107}$ ROSSI, L. E. "I generi letterari e le loro leggi scritte e non scritte nelle letterature classiche". In: Bulletin of the Institute of Classical Studies, 1971, n.18, pp.69-94.

${ }^{108}$ WHEELER, Arthur Leslie. "Tradition in Epithalamium". In: The American Journal of Philology, 1930, vol.51, nº3.
} 
comparada a elementos da natureza; elogio ao noivo, cuja linhagem deve ser destacada; desejo de uma união harmoniosa; exortação do casal a consumar o casamento (de maneira alusiva, não diretamente); profetizar a respeito dos filhos do casal e pedir que sejam como os pais, que, obviamente, têm apenas suas qualidades mencionadas (essa parte costuma aparecer no fim); estabelecer paralelos com exemplos extraídos da mitologia; dissertar a respeito das belezas das estações ou da parte do dia em que o casamento é realizado; entre outras.

Na poesia de Catulo temos outros exemplos de epitalâmio - os poemas 61 e 62 . Observamos que a presença dos elementos mencionados acima é variável nos epitalâmios de Catulo, nos poemas 61 e 62 estão mais evidentes do que no poema 64 .

No poema 61, o metro é o glicônio, adotado na poesia lírica. Observamos grande frequência dos topoi do epitalâmio; uma particularidade é que o poeta destina o canto a um casal cujo noivo parece ser conhecido (o pretor Mânlio Torquato). Invoca-se Hímen, o deus do matrimônio, logo na primeira estrofe, encerrada com uma sentença que servirá de refrão em várias passagens do poema: “[...] o Hymenaee Hymen,/ o Hymen Hymenaee". A primeira parte do poema se divide entre a invocação e o enaltecimento de Himeneu, além de exortar as moças a invocá-lo, ou seja, a casar. Compara o noivo a uma videira que se enlaçará somente na noiva: "lenta sed uelut adsitas/ uitis impicat arbores/ implicabitur in tuum/ complexum. [...]" (v.106-9) e sua linhagem é elogiada entre os versos 221-30. A noiva é comparada a Vênus entre os versos 16 e 19, em seguida, descrita com enfeites de flores; a comparação de sua beleza com flores retorna em outros momentos do poema. A menção às tochas (v.77, 98 e 121 - "faces") remete ao período do dia que, provavelmente, já entardeceu. $\mathrm{O}$ desejo de que o casal tenha filhos e de que eles sejam parecidos com o pai é expresso entre os versos 211 e 215. Enfim, não nos deteremos em tais elementos, pois já estão bem exemplificados.

O poema 62 também foi composto em hexâmetro dactílico e apresenta a divisão estrófica para o canto coral, com um refrão ao fim de cada estrofe que se assemelha ao do poema 61 - “Hymen a Hymenaee, Hymen ades a Hymenaee!”. O objetivo é celebrar a união, por essa razão, as exortações são frequentes, o próprio refrão é uma espécie de exortação e invocação a Himeneu. A mudança de coro efetua-se, a princípio, com a exortação dos rapazes (“iuuenes") e, na estrofe seguinte, das moças (“innuptae”); depois que os dois lados do coro se manifestam, a troca se efetua após o refrão, sem necessidade de introduzir alguma expressão que demonstre quem está a cantar. Aqui a divisão está clara, ao passo que, no poema 61, percebemos que o poeta ocupa o lugar do 
coro como uma espécie de mestre de cerimônias ${ }^{109}$, mas não recusa o coro como parte do canto nupcial, pois no verso 36 ele pede que as moças cantem junto para invocar Himeneu. A menção ao período do dia fica clara no começo do poema com a exortação aos rapazes de que a estrela Vésper - a estrela da tarde, que, segundo a mitologia, teria amado Himeneu - já chegara.

A partir daí, já temos uma contradição que nos permite desconfiar que o poema 64 não seja um epitalâmio. De fato, o poema não aparenta estrutura para um canto coral, o verso hexamétrico é típico da Épica. Entretanto, o mesmo metro foi utilizado no epitalâmio mencionado acima e não se constituiu como problema para a finalidade do gênero. A matéria desse poema é condizente com o epitalâmio, pois canta a união de Tétis e Peleu; porém, já temos nisso uma peculiaridade, pois segundo Fócio-Proclo, o epitalâmio é uma espécie lírica que se refere aos homens, mas Tétis é uma divindade.

O poema, como já dissemos, é um epílio - terminologia moderna para um pequeno poema épico; contudo, o epílio é uma variação desse gênero que, apesar de tratar de temas grandiosos, distingue-se do épico por se concentrar no aspecto emotivo do tema. Apresenta um epos, mas com tratamento um pocuo diferenciado, além de predominar o caráter descritivo, os elementos narrativos aparecem para conferir mais destaque ao tema. Poucos exemplos de epílios chegaram até nós ${ }^{110}$; no entanto, são suficientes para fazer algumas afirmações a respeito dessa variação épica.

Segundo o teórico Carl Jackson ${ }^{111}$, pode-se dizer que há dois tipos de epílio: os heróicos - os poemas gregos (tais como os idílios 24 e 25 de Teócrito), nos quais predominam os elementos homéricos, sobretudo na temática, mas predomina o caráter descritivo no lugar da narração; os "românticos" - concentra-se na temática amorosa, o tipo mais comum e popular, não é possível afirmar quem começou esse tipo de epílio. Devemos, no entanto, ser cautelosos com a terminologia adotada por ele, visto que o termo "romântico" é anacrônico, mas expus a classificação apenas para mostrar a dimensão do epílio que, adotando-se o critério da temática, pode-se ramificar em tipos distintos. Contudo, não é correto afirmar que os epílios tratam, exclusivamente, de matéria heróica ou amorosa (esta é de caráter mitológico), uma vez que muitos poemas do gênero não restaram para confirmação.

\footnotetext{
${ }^{109}$ Proposição de Wheeler, pp.217 - Cf. nota 108.

110 JACKSON, Carl Newell. "The Latin Epyllion". In: Harvard Studies in Classical Philology, 1913, vol.24.

${ }^{111}$ Cf. pp.40 do artigo citado na nota anterior que serviu de base também para a análise de caratcterísticas em comum do epílio com os gêneros épico e elegíaco.
} 
O epílio latino constituía uma manifestação contra a tradição épica vigente na época, uma característica dos poetae noui, grupo ao qual Catulo pertencia. Apesar desse rompimento, reconheciam-se as características épicas consagradas pelo uso em Homero, são algumas delas: símiles, invocações, catálogos, profecias, apóstrofes, epítetos, fraseologia épica, objetividade do poeta épico, cenas vivazes, entre outras. Mais adiante veremos que algumas das características mencionadas acima estão presentes no poema 64 de Catulo.

Alguns aspectos épicos são facilmente notados no epílio de Catulo: a construção de um éthos heróico para Peleu, uma vez que, na Épica, cantam-se os feitos de um herói ${ }^{112}$; o emprego de um recurso retórico-poético comum no gênero épico - a écfrase; não faz a invocação, seguindo a tradição do in medias res; o desfecho de Ariadne não é mencionado, mas fica implícito, Homero já fizera isso na Ilíada, não mostrou o fim da história, mas deixou indícios do que aconteceria.

Com tudo isso, é impossível analisar o poema 64 sem considerar a poikilia, pois a intersecção entre os gêneros se faz presente em cada uma de suas particularidades.

A écfrase se estende dos versos 50 a 264, ocupando grande parte dos 408 versos do poema.

As imagens não são estáticas, pois temos ações e personagens agindo. Dessa forma, o efeito sobre o público ou leitor é muito mais forte, uma vez que se acredita "ver" os acontecimentos e, ainda que por um instante, a matéria principal parece ser esquecida, mas o poeta engenhoso não esquece e trata, na écfrase, de um tema relacionado à matéria.

A écfrase não é um recurso poético exclusivo da Épica mas, como vimos, o primeiro emprego conhecido da figura é na Ilíada, portanto, insere-se na tradição homérica, exemplo maior da poesia épica, que foi depois emulada por outros poetas épicos - isso tornou a écfrase comum no epos.

Algumas referências à écfrase podem ser encontradas na própria passagem em que ela se processa; elas ocorrem de maneira indireta, pois ressaltam o caráter narrativo que subjaz à descrição ou o caráter imagético desse recurso - o que lembra o leitor tratar-se de uma digressão. Encontramos algumas orações que remetem ao universo das cores, da visão ou mencionam uma ação que não ocorre de fato naquele momento ou até

\footnotetext{
${ }^{112}$ Cf. Horácio, na sua Ars Poetica, v.73-4: "Res gestae regumque ducumque et tristia bella/ quo scribi possent numero, monstrauit Homerus." (Em que metro se podem descrever os feitos dos reis, dos chefes, as tristes guerras, já o demonstrou Homero) - Trad. R. M. Rosado Fernandes. 1984.
} 
mesmo não está representada naquela imagem, mas fica implícita na descrição da imagem ali contida; a ação se mistura de tal forma à descrição que podemos dizer que ocorre em praticamente toda a écfrase.

Vejamos então alguns exemplos que pertencem, sobretudo, ao campo semântico visual e algumas expressões que servem para localizar a narração no espaço, além de servir para conectar as imagens na descrição: prospectans (v.52); "necdum etiam sese quae uisit uisere credit [...]" (v.55); prospicit (v.61, 62); "Hunc simula ac cupido conspexit lumine uirgo/ regia [...]" (v.86-7); procul (v.108); protenderet (v.127); "Ille autem prope iam mediis uersatur in undis [...]" (v.167); lumina (v.188); "micantia sidera mundus" (v.206); "caeca mentem caligne Theseus/ consitus [...]” (v.207-8); “inde infecta uago suspendam lintea malo [...] carbasus obscurata [...] ferrugine" (v.225; 227); "candida uela" (v.235).

Analisaremos agora alguns elementos que compõe a poikilia nesse poema, partindo das características de gêneros distintos que estão presentes.

O gênero lírico é polimétrico, portanto, ocorre variação métrica. Quanto à matéria, o amor é a de maior destaque, mas não se confunda com a Elegia, pois na Lírica não temos o páthos lamentoso, resultado do sofrimento amoroso. No entanto, a matéria lírica não se limita ao amor, subdividindo-se em outras espécies por assim dizer: celebrar os deuses - os hinos - cuja nomenclatura varia de acordo com a divindade que se quer louvar; elogio aos homens - encômios; celebrar os vencedores epinícios; cantar celebrações do vinho - lírica simposial; canto nupcial - epitalâmio; entre outros.

No poema aqui estudado, pode-se dizer que estão presentes: o epitalâmio, do qual já falamos, porque o objeto de imitação se constitui em um matrimônio; a lírica amorosa, pois na écfrase, ao contar a história de amor entre Ariadne e Teseu, temos, em dado momento, o amor como temática principal; ouso ainda dizer que o poema tem algo de hino, uma vez que celebra a união de um mortal com uma divindade, Tétis, além de enaltecer outras divindades mais ao fim da écfrase; e, também, algo de ditirambo - hino dedicado ao culto de Dionísio - pois, muitas vezes, aparecem cenas de celebração dionisíaca.

Logo no início, o poema apresenta aspectos que lembram a poesia épica, introduzindo uma narrativa com o uso do verbo "dicuntur" (v.2), empregado como impessoal significa “contam, dizem”. Segue-se explicando como Peleu teria conhecido Tétis, essa parte é tipicamente épica pela narração e também pelo contexto que envolve 
deuses e heróis que, por sua vez, são enaltecidos - "heroes, saluete, deum genus, o bona matrum/ progenies, saluete iterum, saluete, bonarum" (v.23-23b) - lembrando que o éthos do herói épico é de um mortal superior em muitos aspectos, de boa estirpe, de tal maneira que se torna próximo de um deus. No verso 19, o verbo "fertur" cumpre o mesmo papel do "dicuntur" mencionado acima, pois empregado na passiva pode ter a mesma acepção.

Ainda assim, já encontramos indício da Lírica na função do poema - celebrar a união do casal (epitalâmio). O povo da Tessália abandona os trabalhos do campo, demonstrando que o matrimônio é mais importante que qualquer outra atividade, daí pode-se entender que se recusa qualquer outro gênero poético que não seja o epitalâmio, mais especificamente a poesia bucólica (entre os versos 33 e 42), uma vez que o campo constitui o cenário bucólico.

Entre os versos 60 e 65, já na écfrase, a imagem de Ariadne é descrita como "pétrea efígie de bacante"113, o que lembra, logicamente, o culto a Dionísio. No fim da écfrase, a partir do verso 251, essa imagem é retomada quando Dionísio reclama para si o amor de Ariadne. Está implícito aí um dos possíveis destinos para Ariadne, segundo a mitologia, de que teria se casado com Baco. A partir do verso 251 até o fim da écfrase, descreve-se uma celebração dionisíaca que remete ao tema do ditirambo, hino que celebra o deus do vinho, ainda que seja uma breve passagem e que o metro não corresponda, é mais um gênero que encontramos inserido no poema, presente pela temática. O verso 258 chama a atenção para a relação entre a sonoridade e o conteúdo, pois com a leitura percebemos o predomínio do "S" que se assemelharia ao som emitido pela serpente que, por sua vez, aparece na descrição da cerimônia, justamente nesse verso: "pars sese tortis serpentibus incingebant".

No verso 76, o verbo "perhibent" introduz uma nova narrativa que, assim como a écfrase, constitui uma digressão, pois pretende dizer a razão do sofrimento de Ariadne e, para tal, o poeta escolhe começar pelo mito do Minotauro, em seguida, dá a conhecer o éthos heróico de Teseu e só então trata do amor entre os dois.

O poeta nos dá uma breve pista a respeito da estação em que se dá o encontro entre Ariadne e Teseu e ressalta a beleza desse período:

\footnotetext{
${ }^{113}$ Para todas as citações da obra adotamos a tradução de João Angelo O. Neto. O livro de Catulo. São Paulo: Edusp, 1996.
} 
Quales Eurotae progignunt flumina myrtus/ auraue distinctos educit uerna colores [...]

"[...] como, ao fluir, o rio Eurotas gera mirtos/ e a brisa pimavera várias cores traz $[\ldots](\mathbf{v} . \mathbf{8 9 - 9 0})$

Com o término da écfrase, enumeram-se os deuses presentes na cerimônia. Os primeiros a chegar são a Aurora e o Sol que partem logo, antes da chegada dos demais deuses, isso pode significar o fim do dia e a chegada da noite, fase do dia mais propícia à consumação do matrimônio e tópica na temática do epitalâmio.

Reunidos os deuses, surgem as Parcas, divindades que tecem o destino dos mortais, aqui elas tecem o destino do casal cantando (v.323-81) - nesse canto há um misto de Lírica e Épica. O principal elemento lírico dessa parte está bem evidente, tratase do refrão "Currite ducentes subtegmina, currite, fusi", repetido durante o canto das Parcas; o refrão estabelece a estrofe que, por sua vez, é uma característica lírica. O conteúdo da canção ora celebra a união do casal, ora profetiza o futuro de seu filho Aquiles, que sabemos ser herói da guerra de Troia e do poema homérico Ilíada. Ao mesmo tempo, aparecem termos que remetem ao universo lírico e épico:

Aduenit tibi iam portans optata maritis/ Hesperus, aduenit fausto cum sidere coniunx $[$ [...]

Héspero já virá, trazendo o que aos maridos/ praz; com faustosa estrela uma esposa virá [...].(v.328-29)

\section{[...] Troiugenum infesto prosternet corpora ferro.}

[...] com ferro infesto vai prostrar Troianos corpos. (v.355)

Poderíamos imaginar que esse canto é um misto de epitalâmio e encômio, pois celebra o herói Aquiles; no entanto, acredito que a celebração do herói ocorre para ressaltar a comemoração do matrimônio, pois o destino se mostra favorável a tal união. As cenas descritas são tipicamente épicas e nos lembram passagens da própria Ilíada, não devemos, ainda, ignorar aqui a importância do metro hexâmetro que é próprio da Épica. A construção do éthos heróico é conferido não só a Aquiles, como também ao seu pai, uma vez que o herói épico sempre provém de boa estirpe, de fato, a mesma expressão que fala dos feitos de Aquiles é utilizada no começo do canto para enaltecer o noivo da deusa: "magnis uirtutibus" (v.323), cuja tradução (na edição adotada) é "grandes gestas", que remete à matéria épica, porque trata de temas elevados e, partindo 
da expressão em latim, podemos também lembrar outras acepções para "uirtutibus", como as virtudes ou a força do herói.

Trataremos agora dos aspectos elegíacos que permeiam o poema. O metro da poesia elegíaca é o dístico elegíaco, constituído de um verso hexâmetro e um pentâmetro. Essa estrutura era utilizada em inscrições tumulares, daí a relação com a temática do lamento que, por sua vez, é de ordem amorosa ou fúnebre.

O sofrimento elegíaco aparece no poema 64 para ilustrar a dor de Ariadne ao ser abandonada por Teseu. Inúmeras vezes, Ariadne é qualificada com adjetivos que mostram sua condição, tais como: miseram (v.56); "A! misera" (v.71); perdita (v.177); prodita (v.190); saucia (v.250).

Insiro aqui uma breve digressão para expor uma interessante afirmação do teórico Jackson ${ }^{114}$ a respeito da personagem Ariadne. A Medeia do poema épico Os Argonautas é a personagem que teria servido de modelo para Catulo compor o éthos de Ariadne e, até mesmo, para Virgílio compor a Dido, visto que Medeia passa pela mesma situação: apaixona-se, dedica-se ao homem amado e é abandonada por ele, tem, portanto, a mesma situação de sofrimento - a construção dessa personagem representa uma inovação na esfera épica. $\mathrm{O}$ mesmo desespero as acomete e chamam a piedade para si mesma. A situação trágica das personagens leva o poeta a romper com a distância épica, expressando sua compaixão - nesse epílio de Catulo, o poeta se assume como narrador para falar do sofrimento de Ariadne: "Sed quid ego a primo digressus carmina plural commemorem (...)" (v.116). Outro aspecto que é tópico nessa situação é o esquecimento do herói, n'Os Argonautas, Medeia pede para não ser esquecida, enquanto em Catulo, o herói, objeto do amor, já esqueceu, pois Teseu está immemor.

Muitas são as passagens em que a vemos sofrendo e se lamentando copiosamente. Em alguns momentos, ela se lamenta e se mostra arrependida, estando entre o lamento e a imprecação, esse último aspecto é característico da poesia iâmbica, que veremos mais adiante.

No verso 72, "luctibus", traduzido como "choro", significa também "luto", o que nos remete ao campo semântico da poesia elegíaca fúnebre, já que a decepção amorosa faz com que ela não queira mais amar, é como se morresse para o amor. $\mathrm{O}$ termo "querelis" traduz, exatamente, a matéria elegíaca.

${ }^{114}$ Op. cit. na nota 11. Cf. pp.45 do artigo. 
Com a morte do pai, Teseu também fica de luto e, novamente, a matéria fúnebre é lembrada:

Sic funesta domus ingressus tecta paterna/ morte ferox Theseus qualem Minoidi luctum [...]

Entrando assim na casa em luto pela morte/ do pai, Teseu, feroz, a mesma dor que a Ariadne [...] (v. 246-47)

Outra característica elegíaca que está implícita nos lamentos de Ariadne torna-se evidente numa parte da fala dela:

Nunc iam nulla uiro iuranti femina credat,/ nulla uiri speret sermones esse fidelis [...]

Mulher alguma creia em homem que faz juras,/ não creia ser fiel a fala destes homens [...] (v.143-44)

Ariadne aprendeu uma lição com sua experiência e dá um conselho às mulheres para que não sofram o mesmo - temos aqui um exemplo do caráter sapiencial da Elegia, pois, por meio das experiências amorosas, aprende-se a lidar com o sofrimento. A personagem assume a função de magistra. Na Elegia, o poeta, muitas vezes, aconselha seu leitor a respeito de como deve fazer para não passar pelo mesmo, ou tira do sofrimento algum aprendizado para si mesmo, que lembra o caráter proverbial dos Epigramas.

Outro aspecto elegíaco encontrado no poema é a seruitio amoris, expressa no momento em que Ariadne admite a possibilidade de ser apenas uma escrava de Teseu, caso o pai dele não aceitasse a união, ela ficaria feliz nessa condição porque estaria junto dele: "quae tibi iocundo famularer serua labore [...]" (v.161).

Apesar da lamentação, durante sua fala, Ariadne parece recusar a proposta elegíaca de lamentação, uma vez que sofrer apenas não mudará nada:

Sed quid ego ignaris nequiquam conquerar aureis,/ externata malo, quae nullis sensibus auctael nec missas audire queunt nec reddere uoces?

Mas por que em vão por dor prostrada eu vou queixar-me/ aos moucos ventos, que não podem, insensíveis,/ ouvir nem responder às palavras que lanço? (v.164-66) 
No meio dessa recusa, ela fará a única coisa que lhe resta - rogar aos deuses que castiguem Teseu; por isso as passagens elegíacas do poema estão misturadas às passagens iâmbicas, pois em meio ao sofrimento ela o ofende reiteradas vezes e pede para que ele sofra também.

Tratemos agora da poesia iâmbica, já mencionamos que alguns aspectos apareceram na passagem em que Ariadne se lamentava. O caráter iâmbico pode estar na poesia sem que seja, necessariamente, um poema iâmbico, isso ocorre em razão do objetivo desse gênero - invectivar.

Assim como a Lírica, o Iambo é polimétrico, portanto, o gênero não se define por um metro, ainda que haja alguns metros apropriados à temática iâmbica (como, por exemplo, o "iambo manco", pois gera comicidade na elocução). Desse modo, encontrase o caráter iâmbico inserido em poemas de outros gêneros, seu caráter reside não só na invectiva, como também na imprecação, pois esses objetivos estão relacionados, ainda que se possa invectivar sem, obrigatoriamente, imprecar.

Teseu é para Ariadne o objeto de seu amor (matéria lírica e elegíaca), mas é também objeto de seu ódio (matéria própria do Iambo) por causa do abandono. Por essa razão, o gênero iâmbico insere-se no contexto elegíaco da fala de Ariadne e percebe-se que o léxico está dividido (ou relacionado) entre os dois gêneros, pois muitos termos remetem ao sofrimento e, ao mesmo tempo, ao ódio de Ariadne: "Saepe illam perhibent ardenti corde furentem [...]" (v.124).

Durante a fala da personagem, ela o invoca duas vezes consecutivas com o vocativo do adjetivo perfidus - "perfide" (v.132 e 133), portanto, logo no começo, já temos um discurso ofensivo e percebemos o tom invectivo do discurso.

O éthos que Ariadne vai construindo de Teseu é contrário ao éthos heróico com o qual se falou de Peleu e Aquiles, pois ela o ofende reiteradamente, não só a ele, como também a sua estirpe: “deuota domum periuria portas?” (v.135); fallaci (v.151);

Quaenam te genuit sola sub rupe leaena,/ quod mare conceptum spumantibus expuit undis [...]

Que leoa te deu à luz sob ermas penhas?/ Que mar que, prenhe, te cuspiu de espúmeas ondas? (v.154-55) 
Conhecendo o mito, sabemos que Ariadne ajudou Teseu a sair do labirinto, de outra forma, ele não seria vitorioso; o que corrobora a ideia de ingratidão por parte dele e, também, o desvaloriza como herói.

No entanto, isso não significa que Teseu não seja herói, na realidade, justamente por agir como herói épico é que ele a abandona; no próprio poema, afirma-se diversas vezes que Teseu estava "imêmore" (v.58 - “immemor", v.123 - "inmemori", v.135 "inmemor" e v.248 - "mente immemori"), entende-se que algum deus interferiu na sua vontade (segundo as variadas versões do mito, Dionísio queria desposá-la e mandou que ele a deixasse, outra versão diz que Atenas ou Hermes o teria convencido a fazer isso).

Além das ofensas, Ariadne roga aos deuses que o castiguem, temos então a imprecação - dira (terminologia latina) ou ará (terminologia grega). Depois de um longo trecho de lamentação e a triste constatação de que não tem como voltar para casa, não apenas por estar longe e sem meios, mas também por ter traído e abandonado sua família, antecipando para si mesma a morte provável, ela faz a imprecação para que seu sofrimento não seja em vão:

Non tamen ante mihi languescent lumina morte,/ nec prius a fesso secedent corpore sensus,/ quam iustam a diuis exposcam prodita multam, caelestumque fidem postrema comprecer hora/ Quare facta uirum multantes uindice poena,/ Eumenides, quibus anguino redimita capillo/ frons expirantis praeportat pectoris iras,/ huc huc aduentate, meas audite querelas,/ quas ego uae! Misera extremis proferre medullis/ cogor inops, ardens, amenti caeca furore./ Quae quoniam uerae nascuntur pectore ab imo, uos nolite pati nostrum uanescere luctum,/ sed quali solam Theseus me mente reliquit,/ tali mente, deae, funestet seque suosque.

Mas a morte não vai tornar meus olhos lânguidos,/ os sentidos não vão abandonar meu corpo,/ sem que, traída eu peça aos deuses justa pena,/ e à extrema hora a prece dê-me proteção./ Então vós que punis o crime dos mortais,/ Eumênides, serpentes por cabelo tendo/ à fronte, que transpira lá do peito as iras,/ aqui, aqui chegai e ouvi as minhas queixas,/ que lanço à força desde as íntimas medulas,/ desfeita, ardendo, cega de um furor demente./ Porque elas, justas, no mais fundo peito nascem, vós não deixeis que seja vã a minha dor,/ mas tal como Teseu sozinha me esqueceu, assim por esquecer, arruíne a si e aos seus. (v.188-201)

Observamos, no excerto acima, que Ariadne deixa de apenas lamentar e pede punição para Teseu, portanto, o caráter iâmbico do poema se concentra na fala da personagem que procura invectivar Teseu, além de lançar imprecações contra ele. Isso não faz com que o poema seja iâmbico, uma vez que outros gêneros parecem ter mais 
destaque, no entanto, não deixa de ter sua importância, pois corrobora a proposta da poikilia. O poeta Catulo soube utilizar várias facetas de uma mesma matéria para aplicar vários gêneros, esse entrelaçamento entre os gêneros é o que constitui a poikilia.

No desfecho do poema, temos um desvio da temática até então apresentada, pois, independente da variação do gênero, a matéria amorosa predomina; entretanto, encerrado o canto das Parcas, o poeta aproveita o tom profético da canção para falar dos tempos de outrora, quando os deuses ainda viviam entre os mortais, então os homens tornaram-se violentos e os deuses partiram para o Olimpo - isso nos remete ao mito das cinco raças e, consequentemente, ao poema didático de Hesíodo Os Trabalhos e os Dias.

É difícil afirmar qual é a real intenção do poeta com esse aparente desvio temático, mas podemos estabelecer alguma relação entre a narração do poema e o fato mencionado no fim: Teseu é um grande herói na mitologia, digno do gênero épico, contudo, o abandono de Ariadne é tido como uma ação indigna, assim, o leitor é levado a compartilhar do sofrimento dela, recusando, de certa maneira, o éthos heróico dele. Ocorre que, se enquadrarmos a situação apresentada durante todo o poema no mito das raças, Teseu estaria, a princípio, na raça dos heróis; porém, depois de sua atitude, se tornaria indigno da raça, visto que o herói é superior, e seria considerado um homem da raça de ferro, a pior de todas, uma vez que é violenta e nem mesmo os familiares se respeitam, é indigna do convívio com os deuses.

Já observamos que essa atitude pode ser até típica do herói épico, movido pela força do destino. No entanto, considerando-se a estrutura do poema, que é permeado pela mistura dos gêneros, é possível imaginar que a recusa ao éthos heróico é uma maneira de recusar, ainda que no metro hexamétrico, o gênero épico, pois o objetivo não é celebrar os feitos de um herói, mas um matrimônio. Podemos ir mais além e pensar que a variedade de gêneros que compõem o poema é uma forma de reafirmar essa recusa, visto que, toda vez que a Épica predomina no tratamento da matéria, surge algum elemento de um gênero distinto que nos afasta dela novamente.

É certo que a poikilia empregada aqui enriquece muito o poema e o torna mais complexo, mas é também uma tendência da época, não exclusiva de Catulo. Resta-nos então lembrar uma proposição de Aristóteles, anterior a essa época, mas cuja obra nos serve ainda para compreender a poesia antiga: 
Mas os homens ao metro juntaram a palavra "poeta", chamando a uns "poetas elegíacos", a outros "poetas épicos", não segundo a imitação, mas segundo o metro utilizado. E se explicarem um tema de medicina ou de física em verso, é costume aplicar-lhe este nome, mas nada têm em comum Homero e Empédocles com exceção do metro. Por isso, é justo chamar àquele "poeta" e a este "fisiólogo" mais que "poeta". (1447b) $)^{115}$.

O metro é um critério importante para classificar a poesia, mas não é o único, deve-se considerar também o objeto de imitação e a maneira como é operada. Observamos que o poema 64 de Catulo é, pelo metro, épico, mas, apesar do tratamento épico dado a matéria em determinados momentos, o objeto não corresponde à matéria épica e a finalidade também é variável.

Portanto, o poema é mais bem compreendido quando o estudamos no contexto da poikilia. A écfrase deve ser considerada sob essa ótica, visto que apresenta as características usuais do procedimento, mas de modo que colabore para a coexistência dos gêneros. Em algumas passagens exemplificadas acima, nota-se que o caráter patético contribui para a enargia das imagens; a imprecação de Ariadne, por exemplo, é tão intensa que parece ser ouvida.

\section{III.3. SALÚSTIO}

A seguir analisaremos a aplicação da écfrase nas monografias de Salústio. Procuramos adotar o mesmo método utilizado na análise da Eneida; alguns elementos, contudo, não estão presentes na espécie de écfrase manifestada nos retratos. Os textos latinos foram extraídos da edição da Les Belles Lettres.

\section{III.3.1. Guerra de Jugurta}

\section{Jugurta}

6. Qui ubi primum adoleuit, pollens uiribus, decora facie, sed multo maxume ingenio ualidus, non se luxu neque inertiae corrumpendum dedit, sed, uti mos gentis illius est, equitare, iaculari, cursu cum aequalibus certare; et cum omnis gloria anteiret, omnibus tamen carus esse; ad hoc pleraque tempora in uenando agere, leonem atque alias feras primus aut in primis ferire: plurumum facere, minumum ipse de se loqui.

${ }^{115}$ Cf. nota 9 . 
Logo que ele (Jugurta) cresceu, superior nas forças, de bela aparência, mas, sobretudo, muito rico em engenho, não se entregou à corrupção do luxo, tampouco da inércia, mas, como é de costume daquele povo, cavalgava, lançava o dardo, disputava na corrida com os da mesma idade; e excedia a todos em glória, era, contudo, querido por todos; além disso, levava a maior parte do tempo caçando, era o primeiro ou estava entre os primeiros a ferir o leão e outras feras: fazia o máximo e falava o mínimo de si.

Quibus rebus Micipsa tametsi initio laetus fuerat, existumans uirtutem Iugurthae regno suo gloriae fore, tamen postquam hominem adulescentem exacta sua aetate et paruis liberis magis magisque crescere intellegit, uehementer eo negotio permotus, multa cum animo suo uolebat.

Ainda que Micipsa estivesse satisfeito com essas coisas no começo, considerando que a virtude de Jugurta seria a glória de seu reino, contudo, depois de compreender que o jovem homem crescia mais e mais, (Micipsa) na sua idade avançada e de filhos pequenos, veementemente perturbado com essa situação, revolvia muitas coisas no ânimo.

Terrebat eum natura mortalium auida imperi et praeceps ad explendam animi cupidinem, praeterea opportunitas suae liberorumque aetatis, quae etiam mediocris uiros spe praedae transuorsos agit; ad hoc studia Numidarum in Iugurtham accensa, ex quibus, si talem uirum dolis interfecisset, ne qua seditio aut bellum oriretur anxius erat.

Ele temia a natureza dos mortais, ávida por poder e pronta a satisfazer a cobiça da alma, além disso, havia a oportunidade que sua idade e a dos seus filhos oferecia e desencaminha até os homens moderados na esperança dos despojos, além disso, o animado interesse dos númidas em relação à Jugurta, razão pela qual lhe afligia que, se caso matasse tal homem com dolos, surgisse uma revolta ou uma guerra.

$* * *$

A Guerra de Jugurta pertence à historiografia, constitui, mais precisamente, um exemplo de monografia histórica, portanto, os mecanismos descritivos aqui são indispensáveis para as funções desempenhadas pelo gênero.

Na Retórica Herênio observa-se a tipologia do elogio ou do vitupério:

Coisas externas [rerum externarum] são aquelas que podem acontecer por obra do acaso ou da fortuna, favorável ou adversa: ascendência, educação, riqueza, poder, glória, cidadania, amizades, enfim, coisas dessa ordem e seus contrários. Ao corpo [corporis] pertence o que a natureza lhe atribuiu de vantajoso ou desvantajoso: rapidez, força, beleza, saúde e seus contrários. Dizem respeito ao 
ânimo [animi] as coisas que comportam nossa deliberação e reflexão: prudência, justiça, coragem, modéstia, e seus contrários. ${ }^{116}$ (III, 10)

Cícero retoma essa classificação em De Partitione Oratoria, §74-6, cuja explanação mais prolongada fornece diretrizes demonstrando o que seja apropriado omitir ou amplificar. Na classificação ciceroniana, destacam-se as qualidades do ânimo, pois a exposição acerca das virtudes prolonga-se até o $\$ 80$ e prossegue tratando dos vícios.

Os aspectos típicos do elogio ou vitupério compõem, logicamente, o inventário do gênero demonstrativo, cuja função principal é deleitar. Os retratos constituem exemplo desse gênero e servem bem aos propósitos da monografia, que narra um único acontecimento e apresenta as personagens envolvidas de modo pormenorizado para justificar o papel desempenhado por cada uma delas na ação.

Em sua carta a Luceio (Ad Familiares, V, 12), Cícero desenha o gênero da monografia ao pedir para Luceio escrever sobre seu consulado, argumentando que a narração dos feitos de um único homem agradaria mais, visto que a enumeração dos fatos típica dos Anais não desperta o mesmo interesse no leitor. Cícero pede então que essa narrativa seja apartada da história pragmática, ainda que peça para narrar os feitos, delimita a ação narrativa voltada para seu consulado.

Retoricamente, a monografia pode então ser considerada como gênero demonstrativo, uma vez que sua função primordial seria deleitar, segundo os preceitos de Cícero acima discutidos. Ao narrar um único evento, expõe os participantes de maior relevância nos acontecimentos de maneira que alguns sejam elogiados e outros vituperados - as obras de Salústio formam retratos que são produtos desse gênero, opondo as figuras virtuosas às viciosas.

A primeira passagem do capítulo 6 da Guerra de Jugurta produz um retrato de Jugurta, mas não se trata de mero detalhamento das características físicas, é, na realidade, um retrato moral, ou como já definimos nos capítulos anteriores, a etopeia.

Os elementos que servem para a caracterização são variados. Para a construção do éthos, Jugurta reúne características de ordens distintas, ainda que nessa obra o aspecto moral tenha destaque. Logo na primeira parte vemos reunidos diversos elementos: fisicamente é "superior nas forças, de bela aparência", o ânimo "muito rico

\footnotetext{
${ }^{116}$ Cf. nota 2.
} 
em engenho, não se entregou à corrupção do luxo, tampouco da inércia" e a fortuna está implícita quando se afirma ser "querido por todos".

Embora predomine a caracterização física no começo, o que mais se destaca são as qualidades a ele atribuídas, porque entendemos que são suas virtudes morais que agradam aos outros: era inteligente, não era corrupto, tampouco ocioso, além disso, era corajoso e agia mais do que falava.

A enumeração - que como vimos é um recurso típico da amplificação - está presente em toda a descrição de Jugurta. Embora aqui o caráter da écfrase seja estático em relação às ocorrências da Eneida, ao elencar as atividades praticadas por ele, quase presenciamos as ações.

A descrição de Jugurta é constituída também pela reflexão de Micipsa, cuja perturbação indica a presença não mais de um éthos, mas de um páthos, a partir do qual temos conhecimento de seu medo de perder o reino, o que serve para realçar a força de Jugurta, já querido pelos númidas.

A teorização do primeiro capítulo referente à etopeia nos permite concluir que se trata da descrição do caráter de uma personagem real, funciona, portanto, muito bem na monografia, pois - como já afirmamos - essa espécie da historiografia romana se concentra nas figuras mais importantes de um evento, de maneira que seja possível inferir suas atitudes a partir de suas disposições morais, ainda que a caracterização seja breve.

No caso das monografias de Salústio, o éthos é indispensável, uma vez que a oposição entre vício e virtude é fundamental para compreender as ações e suas consequências históricas. Desse modo, cumpre-se a função retória de ensinar, já que tais obras têm caráter exemplar. Na conclusão de sua pesquisa, Ambrosio ${ }^{117}$ destaca a relação entre o discurso demonstrativo e os demais, portanto, a monografia, embora considerada gênero demonstrativo, cumpre bem as funções atribuídas a outros, assim como o docere:

[...] tanto Aristóteles como Cícero e Quintiliano aproximam o encômio dos conselhos, o gênero demonstrativo do deliberativo, insistindo sobre a utilidade cívica do gênero demonstrativo e sua função nos negócios públicos, sobretudo em Roma. Todos os gêneros apóiam-se uns nos outros: os elogios fúnebres dependem de alguma função pública e são confiados aos magistrados, e louvar ou vituperar

\footnotetext{
117 AMBROSIO, Renato. De Rationibus Exordiedi. Os princípios da história em Roma. São Paulo: Humanitas/ Fapesp. 2005.
} 
a testemunha é pertinente ao momento dos julgamentos. Até os discursos compostos para a ostentação, como as laudes uirorum quos priora tempora tulerunt ("os elogios dos personagens ilustres que os tempos passados trouxeram") têm sua função na vida pública.

Os três subgêneros do gênero história, os comentarii, as uitae, e a monografia histórica, estão ligados ao gênero demonstrativo, também se apóiam nos outros gêneros de discursos [...] (AMBROSIO. 2005, pp.152)

O retrato constitui um recurso eficiente para deleitar por seu aspecto digressivo, visto que interrompe a narração e desperta o interesse do leitor. Embora a narração seja suspensa momentaneamente, a digressão não foge aos propósitos do autor que a um só tempo reforça sua argumentação e produz certa expectativa no leitor.

As formas verbais na descrição de Jugurta pertencem a tempos variados, sem predominância de um único, mas desperta atenção a presença das formas nominais que ultrapassam em quantidade as formas cojugadas dos verbos. Destaca-se o infinitvo presente, indispensável em passagens descritivas que elencam as atividades executadas pelo indivíduo. O particípio perfeito e também o particípio presente ocorrem, com menor frequência, auxiliando na caracterização da personagem, pois alguns aspectos são implicados sem demonstração de uma ação direta.

Isso contribui para a brevidade da narrativa da monografia, pois tudo deve convergir para a ação principal; portanto, as caracterizações contribuem para o percurso narrativo, mas como digressões, não devem ocupar grande parte da narração.

\section{Mário}

63. Per idem tempus Vticae forte C. Mario per hostias dis subplicanti magna atque mirabilia portendi haruspex dixerat: proinde, quae animo agitabat, fretus dis ageret, fortunam quam saepissume experiretur; cuncta prospere euentura.

Nessa mesma época, por acaso, C. Mário, em Útica, um adivinho lhe dissera, rendendo sacrifícios aos deuses, coisas grandes e admiráveis de pressagiar: assim, fizesse aquilo que revolvia no ânimo, apoiado nos deuses, e que suportasse o máximo possível a fortuna; todo o futuro seria próspero.

At illum iam antea consulatus ingens cupido exagitabat, ad quem capiundum praeter uetustatem familiae alia omnia abunde erant: industria, probitas, militiae magna scientia, animus belli 
ingens, domi modicus, lubidinis et diuitiarum uictor, tantum modo gloriae auidus.

Já antes, porém, um forte desejo do consulado o revolvia, para conseguir, exceto pela antiguidade da família, era abundante em todas as outras coisas: o empenho, a probidade, o grande conhecimento no serviço militar, ânimo forte na guerra, moderado na paz, vencedor sobre a paixão e a riqueza, ávido somente de glória.

Sed is natus et omnem pueritiam Arpini altus, ubi primum aetas militiae patiens fuit, stipendiis faciundis, non Graeca facundia neque urbanis munditiis sese exercuit: ita inter artis bonas integrum ingenium breui adoleuit.

Ele nasceu e passou toda a infância em Arpino, logo que teve idade para suportá-lo, foi para o serviço militar, serviu nos exércitos, não na eloquência grega, tampouco nos adornos urbanos: desse modo, entre boas ocupações, em pouco tempo cresceu a íntegra índole.

Ergo ubi primum tribunatum militarem a populo petit, plerisque faciem eius ignorantibus, facile notus per omnis tribus declaratur.

Por isso, logo que pediu o tribunato militar ao povo, foi facilmente reconhecido, ainda que a maior parte desconhecesse seu rosto, e foi nomeado por todas as tribos.

Deinde ab eo magistratu alium post alium sibi peperit, semperque in potestatibus eo modo agitabat, ut ampliore quam gerebat dignus haberetur.

Depois, a partir dessa magistratura, obteve para si uma após a outra e, sempre, de tal modo as exercia com valor, que era considerado digno de adquirir uma de maior importância.

Tamen is ad id locorum talis uir - nam postea ambitione praeceps datus est - consulatum adpetere non audebat.

Contudo, tal homem não ousava até então buscar o consulado depois, por causa da sua ambição, foi levado à ruína.

Etiam tum alios magistratus plebs, consulatum nobilitas inter se per manus tradebat.

Até então, a plebe tinha outras magistraturas, a nobreza transmitia de mão em mão o consulado entre si.

Nouos nemo tam clarus neque tam egregiis factis erat, quin is indignus illo honore et quasi pollutus haberetur.

Nenhum homem novo, por mais notável, por mais honrosos feitos que tivesse, ainda seria considerado infame para que fosse digno de tal honra. 
Antes mesmo da elaboração de um éthos, tomamos conhecimento do páthos de Mário, que almejava projetos difíceis de realizar. Ao longo da descrição, sabemos que ele deseja obter as mais altas magistraturas, o que não lhe é possível em razão de sua origem humilde.

O relato acerca de Mário o descreve por meio do ânimo, o aspecto físico não é importante nessa passagem e os fatores externos não lhe seriam favoráveis; Salústio se concentra nas virtudes que conduziram Mário a obter cargos que outros na sua condição não conseguiram. Condição essa que ganha destaque, pois surge logo no princípio de sua descrição: “[...] um forte desejo do consulado o revolvia, para conseguir, exceto pela antiguidade da família, era abundante em todas as outras coisas [...]".

Observamos também o emprego da enumeração aqui que, no caso do retrato de Mário, tem um efeito acumulativo que faz sobressair suas qualidades sobre aquilo que seria seu único defeito: sua origem.

A personagem nos é apresentada como o indivíduo que protege a nação por meio do serviço militar, suas virtudes são apropriadas para tal. A facúndia é então mostrada como uma qualidade desnecessária para suas ocupações.

Nessa passagem, contudo, a descrição não é tão estática uma vez que observamos uma breve sequência temporal enumerando a trajetória de Mário: vemos sua ascensão a partir de sua boa reputação e antevemos sua queda - fato não relatado na monografia - por ambicionar o consulado.

Diferentemente do que verificamos no capítulo de Jugurta, o tempo verbal predominante nessa passagem é o pretérito imperfeito, seguido do pretérito perfeito e da forma nominal do particípio pretérito. Percebemos progressão na enumeração dos principais fatos dessa breve biografia de Mário; ainda que o texto mantenha-se conciso, as ações representadas por verbos conjugados no passado conferem mais dinâmica ao texto, cujos eventos são realmente narrados e não propriamente caracterizados como quando ficam subentendidos por formas nominais dos verbos que desempenham também função adjetiva.

\section{III.3.2. Conjuração de Catilina}




\section{Catilina}

5. L. Catilina, nobili genere natus, fuit magna ui et animi et corporis sed ingenio malo prauoque.

Lúcio Catilina, nascido em família nobre, era de grande força espiritual e corporal, mas de caráter mal e depravado.

Huic ab adulescentia bella intestina, caedes, rapinae, discordia ciuilis grata fuere, ibique iunentutem suam exercuit.

Desde a adolescência, lhe eram agradáveis as guerras internas, a matança, os roubos e a discórdia civil, e em tais coisas exercitou sua juventude.

Corpus patiens inediae, algoris, uigiliae, supra quam cuiquam credibile est.

Um corpo que resiste à fome, ao frio, à vigília, mais do que alguém possa acreditar.

Animus audax, subdolus, uarius, cuius rei lubet simulator ac dissimulator, alieni adpetens, sui profusus, ardens in cupiditatibus: satis eloquentiae, sapientiae parum.

O espírito audaz, astuto, versátil, fingidor e dissimulador do que lhe aprouver, desejoso do que é alheio, dissipador do seu, sedento em desejos: de bastante eloquência, de pouca sabedoria.

Vastus animus inmoderata, incredibilia, nimis alta semper cupiebat.

O espírito desregrado desejava sempre as coisas imoderadas, incríveis e excessivamente grandes.

Hunc post dominationem L. Sullae lubido maxuma inuaserat rei publicae capiundae, neque id quibus modus adsequeretur, dum sibi regnum pararet, quicquam pensi habebat.

Depois do domínio de L. Sila, um desejo violento de tomar a república apossou-se dele, contanto que conseguisse o reino para si, não pesava qualquer coisa, nem por quais meios alcançaria isso.

Agitabatur magis magisque in dies animus ferox inopia rei familiaris et conscientia scelerum, quae utraque is artibus auxerat, quas supra memoraui.

O ânimo feroz dia a dia era mais e mais atormentado pela privação dos bens familiares e pela consciência dos seus crimes; ambos aumentaram com seus artifícios, os quais relatei antes. 
Incitabant praeterea corrupti ciuitatis mores, quos pessuma ac diuorsa inter se mala, luxuria atque auaritia, uexabant.

Além disso, o incitavam os costumes corruptos da cidade que a assolavam, vícios diversos entre si e dos piores, a luxúria e a cobiça.

Res ipsa hortari uidetur, quoniam de moribus ciuitatis tempus admonuit, supra repetere ac paucis instituta maiorum domi militiaeque, quo modo rem publicam habuerint quantamque reliquerint, ut paulatim inmutata, ex pulcherruma 〈atque optuma> pessuma ac flagitiosissuma facta sit, disserere.

Já que a ocasião fez lembrar os costumes da cidade, o próprio assunto parece instigar a retomar os princípios dos antepassados na paz e na guerra, discorrer de que modo teriam administrado a república e o quão grande a deixaram, como paulatinamente foi transformada, tornou-se da mais bela <e melhor>, a pior e a mais torpe.

$* * *$

Salústio pretende narrar unicamente a conjuração de Catilina nessa obra, antes, porém, julga necessário discorrer acerca do caráter dele - mais uma vez temos a écfrase como digressão, mas não menos necessária em razão disso. O éthos de Catlina é construído de tal maneira pelo historiador que antes mesmo dos acontecimentos já o condenamos por seus vícios.

A breve descrição física demonstra grandeza e destaca-se sua nobre origem, paralalelamente, no entanto, as características que pertencem ao ânimo são negativas, contrapondo-se às qualidades. Os vícios se sobrepõem às virtudes e observamos também a apresentação de um páthos, uma vez que a ambição toma conta de Catilina: a corrupção dos costumes da urbe parece estar refletida na personalidade dele, um indivíduo repleto de qualidades, mas corrompido, aspecto que o levará à ruína.

O retrato de Catlina é também uma digressão extremamente importante para a composição da obra: a devastação moral de Catilina corresponde à devastação dos princípios deixados pelos antepassados em Roma.

A exemplo do que vimos no retrato de Mário, predominam aqui tempos verbais do pretérito, com a diferença de que se emprega mais o pretérito perfeito do indicativo, seguido do imperfeito do indicativo. No caso de Mário, as formas conjugadas auxiliavam a conferir movimentação, mas há também várias ocorrências de formas nominais em ambas as passagens - com quase a mesma extensão da descrição de Mário; o texto referente à Catilina não reflete tanta movimentação, pois as ações são reduzidas 
se traçamos esse paralelo com o retrato daquele, prevalecendo sobretudo a caracterização moral em detrimento das ações.

As formas participiais no pretérito no gênero épico contribuíam para explorar as possibilidades narrativas de uma única imagem; nos retratos de Salústio, tais formas aparecem ora como formas adjetivas, ora como constituintes do pretérito perfeito na voz passiva. O particípio presente que, embora não seja predominante na descrição de Catilina, aparece nos retratos com regularidade e contribui funcionando não apenas como adjetivo, mas também ajudando a presentificar o retrato das personagens, cuja qualificação é remetida ao momento presente $^{118}$. Esse mecanismo confere mais vivacidade à descrição, produzindo uma enargia no discurso; conforme já discutimos, o particípio presente favorece a qualificação e a movimentação ao mesmo tempo, visto tratar-se de uma forma verbal e adjetiva.

\section{Semprônia}

25. Sed in eis erat Sempronia, quae multa saepe uirilis audaciae facinora conmiserat.

Mas, entre elas, estava Semprônia que, frequentemente, cometera muitos atos criminosos, de viril audácia.

Haec mulier genere atque forma, praeterea uiro, liberis satis fortunata fuit; litteris Graecis et Latinis docta, psallere, saltare elegantius quam necesse est probae, multa alia, quae instrumenta luxuriae sunt.

Essa mulher foi bastante afortunada pela origem e pela beleza, além disso, pelo marido e filhos; (era) douta em letras gregas e latinas, tocava cítara, dançava mais graciosamente do que era necessário a uma mulher honesta, e muitas outras características, que são instrumentos da luxúria.

Sed ei cariora semper omnia quam decus atque pudicitia fuit; pecuniae an famae minus parceret, haud facile discerneres; lubido sic accensa, ut saepius peteret uiros quam peteretur.

Mas todas as coisas para ela sempre foram mais caras do que a dignidade e o pudor; dificilmente discernirias se respeitava menos o dinheiro ou a fama; um desejo de tal modo inflamado que mais frequentemente buscava os homens do que era buscada.

\footnotetext{
${ }^{118}$ Breve comentário acerca do uso do particípio presente na historiografia grega encontra-se no artigo: WALKER, A. D. "Enargeia and the Spectator in Greek Historiography". In: Transactions of the American Philological Association. 1993, vol. 123, pp.353-377. Cf. pp. 365.
} 
Sed ea saepe antehac fidem prodiderat, creditum abiurauerat, caedis conscia fuerat, luxuria atque inopia praeceps abierat.

Antes disso, porém, ela traíra a confiança, negara a dívida, fora cúmplice de matança, abandonara-se, precipite, à luxúria e à miséria.

Verum ingenium eius haud absurdum: posse uersus facere, iocum mouere, sermone uti uel modesto uel molli uel procaci; prorsus multae facetiae multusque lepos inerat.

Seu engenho, na verdade, não era comum: sabia fazer versos, provocar o riso, com uma conversa discreta, agradável ou ousada; em resumo, tinha muita jovialidade e muito encanto.

$* * *$

O breve retrato de Semprônia nos traz novamente a oposição vício e virtude. Inicialmente são expostas suas qualidades em todos os aspectos propostos na Retórica a Herênio - coisas externas, o corpo e o ânimo. Logo em seguida, porém, os defeitos são enumerados de tal maneira que obscurecem as virtudes. Salústio produz assim o par correspondente à Catilina.

A enumeração é essencialmente o recurso adotado nessa etopeia e expõe ora as qualidades, ora os defeitos. O processo enumerativo concentra-se mais nas qualidades negativas, vituperando de modo que o leitor se horrorize com o comportamento inadequado para uma mulher. A descrição torna o retrato mais dinâmico e vivaz, detalhando seu comportamento depravado e, assim, aproximando-se mais desse leitor. É isso que Quintiliano ensina para tornar o discurso mais vivaz, pormenorizar, não apenas citar.

Na primeira linha temos a expressão que norteia a descrição: "uirilis audaciae", apesar de todas as características femininas que seguem, sua audácia é típica de um homem.

Contudo, existe uma hipótese ${ }^{119}$ de que Semprônia seria uma "versão" feminina de Catlina, Boyd ${ }^{120}$, no entanto, questiona essa explicação simplista da figura de Semprônia, principalmente por não haver evidências históricas da participação de alguma Semprônia na conspiração, além disso, a personagem pouco aparece na narrativa.

\footnotetext{
119 BOYD, B.W. "Virtutes Effeminata and Sallust's Sempronia". In: Transactions of the American Philological Association. 1987, vol.117, pp.183-201.

${ }^{120}$ Op. cit. nota acima. Cf. pp.183-84.
} 
O retrato de Semprônia sucede a passagem que menciona o apoio que Catilina obteve de algumas mulheres, de moral indecente - o retrato de Semprônia nada mais seria do que uma representação do tipo de mulher que serve aos propósitos da conjuração. A figura de Semprônia seria, segundo Boyd, ao mesmo tempo o complemento de Catilina e seu oposto, pois, ainda que haja semelhanças, trata-se de uma mulher que nunca poderá alcançar a glória reservada aos homens. Semprônia ultrapassa os limites permitidos às mulheres, possuidora de virtudes que não lhes são apropriadas. O mesmo ocorre a Catilina, cheio de qualidades, mas ao corrompê-las, deixa de ter as apropriadas virtudes de um homem e não poderá verdadeiramente alcançar a glória de um homem virtuoso.

Após termos visto o quadro de Catilina e de uma figura feminina, constatamos que a corrupção dos costumes em Roma atingia a todos - a ruína moral devastava a cidade.

Por tratar-se de uma descrição mais breve em comparação com as demais, a conjugação dos verbos não apresenta grandes variações. Destaca-se o infinitivo presente, necessário no contexto da enumeração de suas habilidades; e também o pretérito mais-que-perfeito do indicativo, indicando as ações imorais que Semprônia já cometera antes mesmo da conspiração, delineando um éthos vicioso típico da personagem.

\section{Catão e César}

53. Postquam Cato adsedit, consulares omnes itemque senatus magna pars sententiam eius laudant, uirtutem animi ad caelum ferunt, alii alios increpantes timidos uocant.

Depois que Catão se sentou, todos os consulares e igualmente grande parte do senado, louvaram seu discurso, exaltaram a virtude de sua alma até o céu, alguns, censurando, chamaram os outros de medrosos.

Cato clarus atque magnus habetur. Senati decretum fit sicuti ille censuerat.

Catão era considerado famoso e grande. O decreto do senado era feito conforme ele opinava. 
Sed mihi multa legenti, multa audienti, quae populus Romanus domi militiaeque, mari atque terra, praeclara facinora fecit, forte lubuit adtendere, quae res maxume tanta negotia sustinuisset.

Porém, para mim, que li muitas coisas, que ouvi muitas coisas, as quais o povo romano fez, ações memoráveis, na paz e na guerra, no mar e na terra, por acaso, aprouveu-me considerar que evento teria sustentado, precisamente, tantos trabalhos.

Sciebam saepenumero parua manu cum magnis legionibus hostium contendisse.

Eu sabia que, frequentemente, tinha lutado um exército pouco numeroso contra grandes legiões de inimigos.

Cognoueram paruis copiis bella gesta cum opulentis regibus, ad hoc saepe fortunae uiolentiam tolerauisse, facundia Graecos, gloria belli Gallos ante Romanos fuisse.

Tomara conhecimento de façanhas bélicas contra reis poderosos, além disso, frequentemente, tinha suportado a violência da Fortuna, a frente dos romanos estavam os gregos na eloquência e os gauleses na glória da guerra.

Ac mihi multa agitanti constabat paucorum ciuium egregiam uirtutem cuncta patrauisse eoque factum uti diuitias paupertas, multitudinem paucitas superaret.

E era evidente para mim, refletindo muito, que a virtude notável de alguns poucos tinha executado tudo e, com isso, a pobreza superara a riqueza, o pequeno número, a multidão.

Sed postquam luxu atque desidia ciuitas corrupta est, rursus res publica magnitudine sua imperatorum atque magistratuum uitia sustentabat ac, sicuti effeta parentum ui, multis tempestatibus haud sane quisquam Romae uirtute magnus fuit.

Mas, depois que a cidade foi corrompida pelo luxo e pela ociosidade, então a república sustentava com sua magnitude os vícios dos generais e dos magistrados e, como uma mãe infecunda, não existiu, certamente, alguém grande de virtude em Roma durante muito tempo.

Sed memoria mea ingenti uirtute diuorsis moribus fuere uiri duo, M. Cato et C. Caesar: quos quoniam res obtulerat, silentio praeterire non fuit consilium, quin utriusque naturam et mores, quantum ingenio possem, aperirem.

Mas, no meu tempo, existiu M. Catão e C. César, dois homens de grande virtude, de costumes diferentes: já que a situação os apresentou, não tive a intenção de deixar passar isso em silêncio, ao contrário, exporei a natureza e os costumes de ambos com quanto engenho seja possível. 
54. Igitur eius genus, aetas, eloquentia, prope aequalia fuere, magnitudo animi par, item gloria, sed alia alii.

Pois foram quase iguais na sua origem, idade, eloquência, semelhantes na grandeza da alma, igualmente, na glória, mas cada um do seu modo.

Caesar beneficiis ac munificentia magnus habebatur, integritate uitae Cato.

César era considerado grande pelos favores e pela generosidade, Catão, pela integridade da vida.

Ille mansuetudine et misericordia clarus factus, huic seueritas dignitatem addiderat.

Aquele se tornou famoso pela brandura e compaixão, a esse último, a severidade acrescentara dignidade.

Caesar dando, subleuando, ignoscendo, Cato nihil largiundo gloriam adeptus est.

César alcançou a glória, dando, auxiliando, perdoando, Catão, não oferecendo qualquer coisa.

In altero miseris perfugium erat, in altero malis pernicies.

Em um, existia um refúgio para os miseráveis, no outro, a ruína para os maus.

Illius facilitas, huius constantia laudabatur.

Louvava-se a complacência daquele e a firmeza deste.

Postremo Caesar in animum induxerat laborare, uigilare, negotiis amicorum intentus sua neglegere, nihil denegare quod dono dignum esset; sibi magnum imperium, exercitum, bellum nouom exoptabat, ubi uirtus enitescere posset.

Por fim, César resolvera trabalhar, vigiar, renunciar às suas coisas, aplicado aos negócios dos amigos, nada recusar que fosse digno de ser dado; desejava para si um grande império, um exército, uma guerra singular, onde sua virtude poderia brilhar.

At Catoni studium modestiae, decoris, sed maxume seueritatis erat.

Catão, porém, tinha o hábito da modéstia, do decoro, mas, sobretudo, da severidade. 
Non diuitiis cum diuite neque factione cum factioso, sed cum strenuo uirtute, cum modesto pudore, cum innocente abstinentia certabat, esse quam uidere bonus malebat: ita quo minus petebat gloriam, eo magis illum sequebatur.

Não rivalizava em riquezas com o rico, nem em poder com o poderoso, mas com o zeloso em virtude, com o moderado em pudor, com o honesto em desinteresse, preferia ser bom, a parecer bom: assim, quanto menos buscava a glória, mais ela o seguia.

$* * *$

Depois de dois longos discursos de César e Catão, Salústio expõe o retrato de ambos, concentrando-se sobretudo nas qualidades do ânimo. É interessante observar que o discurso - um tipo de digressão - é o mote que conduz a outra espécie de digressão na monografia, que é o retrato.

O capítulo 53 sucede o discurso de Catão. Embora virtuoso, ele divide opiniões. Em vez de inserir o retrato de Catão aqui, o autor remonta os feitos do povo romano em tempos de glória e afirma que a virtude de poucos trouxe as conquistas aos romanos; no entanto, depois da degradação moral da cidade, os homens honrados eram ainda mais escassos. Dessa maneira, o autor introduz os dois retratos simultaneamente, dois homens diferentes, mas de grande virtude.

No capítulo 54, a caracterização de César e Catão é feita por meio de oposições: enquanto o primeiro é brando e complacente, o segundo é severo e firme, e assim prossegue a enumeração de suas qualidades. Os dois são considerados exemplares, contudo, temos a impressão de que o excesso de qualidades não é o ideal, mas o equilíbrio delas, a temperança; ainda assim, ambos são modelos de conduta porque agem guiados por virtudes e não por vícios. Apesar de César ambicionar para si um grande império, isso não o corrompe da mesma maneira que Catilina foi corrompido por suas ambições.

Essa passagem pode ser enquadrada na classificação de $\operatorname{Hamon}^{121}$, que inclui dentre os tipos de descrição o paralelo, que consiste na "combinação de duas descrições, por meio de semelhança ou antítese, de objetos ou personagens". Nesse caso, temos a antítese das personages. Além disso, trata-se também de um retrato, inserido na tipologia do teórico; ainda que se restrinja aos aspectos morais e não nos apresente detalhadamente os dois indivíduos, importa para essa monografia demonstrar a virtude, é necessário, portanto, construir um éthos e não propriamente uma imagem.

${ }^{121}$ Cf. nota 69. 
Apesar da falta de elementos visuais que nos permitam ver o referente, a descrição de suas características é listada de maneira sucinta, mas pormenorizada, permitindo-nos ir além e não somente imaginar uma estrutura física; vemos as ações das personagens, cuja conduta é regulada pelas virtudes: um perdoa, ajuda, abriga os miseráveis, trabalha, vigia, renuncia às suas coisas para ajudar os amigos; o outro nada dá, é implacável, firme, modesto, severo, não busca conquistas.

César é mais dinâmico, contribuindo na trasmissão do éthos de uma figura que era conhecido pelas batalhas e que se tornará célebre na história romana. Ambrosio ${ }^{122}$ afirma que Salústio consideraria a proposta de César como a melhor, visto que ele era possuidor não apenas das virtudes do ânimo, como também de força corpórea, necessária durante a guerra - ele era capaz de atuar na paz e na guerra, e é nessa última que surgem os melhores homens. Catão distinguia-se apenas pela virtude do ânimo.

No capítulo 53, embora haja equilíbrio no emprego das formas verbais, o tempo verbal predominante é o pretérito perfeito do indicativo - o uso do perfeito ocorre principalmente ao tratar de fatos passados de Roma (os feitos e as causas da corrupção).

No capítulo seguinte, a concentração maior pertence ao pretérito imperfeito do indicativo, designando a ação dos retratados no decorrer de um tempo passado em relação à narrativa, enumerando ações que os caracterizam. A forma nominal do infinitivo presente também é bem frequente para listar as ações típicas dos dois, funcionando como complementos de outros verbos que os introduzem; ressaltemos que o infinitivo predomina na descrição de César, uma vez que ele é apresentado como um indivíduo de grande generosidade e suas ações são mais numerosas que as de Catão, mais comedido.

As duas obras de Salústio aqui analisadas são célebres exemplos da monografia histórica, ambas discorrendo acerca de dois fatos importantes na história romana, com a particularidade de que o conflito contra Jugurta é externo, enquanto a conspiração de Catilina era interna; por essa razão, as caracterizações do éthos são marcadas pela opsição vício e virtude na Conjuração de Catilina, discussão cara à obra.

Com base na observação da écfrase no gênero épico, conclui-se que o mesmo procedimento na monografia apresenta caráter mais estático, configurada por meio da etopeia. A poesia épica também apresenta a écfrase em passagens digressivas, mas nesse gênero a narração de eventos é indispensável para o prosseguimento do poema; ao

${ }^{122}$ Cf. nota 117. 
passo que a monografia focaliza apenas um evento e as écfrases presentes estão desligadas da ação, importam para a apresentação das personagens. No épico, a écfrase serve como dispositivo para narrar ainda uma outra ação que não seja a central do poema, isso não ocorre na monografia.

Reforça-se, portanto, a variedade dos mecanismos ecfrásticos que dependem do contexto da obra e adpatam-se também ao gênero. Na Eneida, uma digressão que relembra a guerra de Troia é até mesmo necessária para a introdução da ação principal. Na Conjuração de Catilina, não faria sentido divagar, por exemplo, acerca das ações de Catilina, seu éthos é perfeitamente transmitido sem que se mostrem as batalhas das quais participou, pois tomaria espaço numa narrativa para a qual seria dispensável basta sabermos que ele é sedento por guerras.

Essa afirmação se refere exclusivamente aos retratos observados na monografia, uma vez que em outras espécies historiográficas a écfrase pode resultar diferente. Como não fazem parte de nosso objeto de pesquisa, não trataremos disso, mas fica a ressalva para que não se interprete equivocadamente que a conclusão acima engloba toda a historiografia.

Afirmar categoricamente que a écfrase narrativa não ocorre na monografia, contudo, seria um erro. No capítulo 101 da Guerra de Jugurta temos a descrição do combate na cidade de Cirta, a vivacidade com que é descrita lembra, salvo as diferenças de gênero, o ambiente épico, cuja narrativa apresenta várias ações das personagens envolvidas.

Nosso objetivo foi apenas estudar os retratos de maior destaque nas monografias de Salústio, no entanto, essa écfrase dinâmica na Guerra de Jugurta permite corroborar a tese de que outros subgêneros da história apresentem écfrases de caráter épico.

Demétrio, em seu tratado De Elocutione, \$219, afirma que toda representação tem um elemento de vivacidade (enarges); acredito ter-se provado nas análises até aqui expostas que a écfrase é um mecanismo amplamente adotado para provocar a enargia.

A antiga historiografia objetivava a verossimilhança, apresentando aparência de verdade e não os fatos em si, segundo Walker ${ }^{123}$ tal resultado se comprovava pelo grau de visualização percebida pelo leitor. A enargia é o aspecto que deve predominar no texto, mas os procedimentos para produzi-la são variáveis. Aqui é possível reforçar a distinção entre a écfrase e a enargia, visto que a última é característica apropriada aos

${ }^{123}$ Op. cit. na nota 118. Cf. pp. 374 do artigo. 
textos, para reforçar os efeitos esperados; a écfrase é um típico processo pelo qual se forma a enargia, entretanto, uma descrição simples e sem ornamentação pode falhar em produzir esse efeito.

\section{III.4. SUETÔNIO}

\section{O Divino Júlio - Livro I do De Vita Caesarum}

Por fim, analisaremos a aplicação da écfrase na uita de Suetônio a respeito de

Júlio César. Os textos latinos foram extraídos da edição da Loeb Classical Library.

1. Annum agens sextum decimum patrem amisit; sequentibusque consulibus flamen Dialis destinatus dimissa Cossutia, quae familia equestri sed admodum diues praetextato desponsata fuerat, Corneliam Cinnae quater consulis filiam duxit uxorem, ex qua illi mox Iulia nata est; neque ut repudiaret compelli a dictatore Sulla ullo modo potuit.

Ao fazer dezesseis anos perdeu o pai; designado flâmine de Júpiter nos consulados seguintes, separou-se de Cossúcia, que é de família equestre, mas muito rica, lhe fora prometida quando vestia a toga pretexta. Casou-se com Cornélia, a filha de Cina, quatro vezes cônsul, da qual depois lhe nasceu Júlia; de modo algum pôde ser impelido pelo ditador Sila para rejeitá-la.

2. Quare et sacerdotio et uxoris dote et gentilicis hereditatibus multatus diuersarum partium habebatur, ut etiam discedere e medio et quamquam morbo quartanae adgrauante prope per singulas nocte commutare latebras cogeretur seque ab inquisitoribus pecunia redimeret, donec per uirgines Vestales perque Mamercum Aemilium et Aurelium Cottam propinquos et adfines suos ueniam imperauit.

Por essa razão, foi privado do sacerdócio, do dote da esposa e das heranças de família, era considerado dos partidos dos inimigos, de modo que até foi impelido a afastar-se da sociedade, a mudar os esconderijos quase todas as noites, ainda que com o agravamento da doença da febre quartã, e a livrar-se dos investigadores com dinheiro. Até que obteve o perdão, por meio das virgens Vestais, de Mamerco Emílio e Aurélio Cota, seus parentes e cúmplices.

3. Satis constat Sullam, cum deprecantibus amicissimis et ornatissimis uiris aliquandiu denegasset atque illi pertinaciter contenderent, expugnatum tandem proclamasse siue diuinitus siue aliqua coniectura: uincerent ac sibi haberent, dum modo scirent eum, quem incolumen tanto opere cuperent, quandoque optimatum partibus, quas secum simul defendisset, exitio futurum; nam Caesari multos Marios inesse. 
É bem certo que Sila, durante algum tempo, tinha recusado aos suplicantes muito amigos e distintos que obstinadamente contendiam por ele; finalmente, vencido, proclamou por vontade divina ou por alguma outra conjetura: que venciam e o tivessem, contanto que soubessem que ele, quem, com tanto trabalho desejavam incólume, um dia, seria a ruína do partido dos nobres, o qual tinham defendido juntos; pois há em César muitos Mários.

2. Stipienda prima in Asia fecit Marci Thermi praetoris contubernio; a quo ad accersendam classem in Bithyniam missus desedit apud Nicomeden, non sine rumore prostratae regi pudicitiae; quem rumorem auxit intra paucos rursus dies repetita Bithynia per causae exigendae pecuniae, quae deberetur cuidam libertino clienti suo. Reliqua militia secundiore fama fuit et a Themo in expugnatione Mytilenarum corona ciuica donatus est.

Serviu no exército pela primeira vez na Ásia na companhia do pretor Marcos Termo; por quem foi enviado à Bitínia para buscar uma esquadra, ficou ocioso na casa de Nicomedes, não sem o rumor de ter prostituído sua honra ao rei; ele aumentou o rumor ao retornar pouco tempo depois à Bitínia, com o pretexto de cobrar o dinheiro que lhe era devido por certo liberto, cliente seu. A campanha restante foi de melhor reputação e a coroa cívica lhe foi dada por Termo na tomada de Mitilene.

3. Meruit et sub Seruilio Isaurico in Cilicia, sed breui tempore. Nam Sullae morte comperta, simul spe nouae dissensionis, quae per Marcum Lepidum mouebatur, Romam propere redit. Et Lepidi quidem societate, quamquam magnis condicionibus inuitaretur, abstinuit, cum ingenio eius diffisus tum occasione, quam minorem opinione offenderat.

Serviu também sob o comando de Servilio Isaurico na Cilícia, mas por pouco tempo. Pois, tendo sabido da morte de Sila, juntamente com a expectativa do novo conflito que era movido por Marcos Lépido, voltou depressa para Roma. Porém, apartou-se da aliança de Lépido, ainda que fosse convidado com grandes propostas, desconfiado, por um lado, do engenho dele, por outro, da ocasião, que o desagradara por ser menor do que sua expectativa.

6. Quaestor Iuliam amitam uxoremque Corneliam defunctas laudauit e more pro rostris. Et in amitae quidem laudatione de eius ac patris sui utraque origine sic refert:

"Amitae meae Iuliae maternum genus ab regibus ortum, paternum cum diis inmortalibus coniunctum est. Nam ab Anco Marcio sunt Marcii Reges, quo nomine fuit mater; a Venere Iulii, cuius gentis familia est notra. Est ergo in genere et sanctitas regum, qui plurimum inter homines pollent, et caerimonia deorum, quorum ipsi in potestate sunt reges."

Quando era questor, elogiou nos rostros as falecidas tia Júlia e a esposa Cornélia, de acordo com o costume. E no elogio de sua tia ele contou a respeito da sua origem dos dois lados e também de seu pai. 
"O lado materno de minha tia Júlia nasceu de reis, o paterno é parente de deuses imortais. Pois os Márcios Reis, nome que sua mãe teve, são de Anco Márcio; os Júlios, de Vênus, de cuja raça é a nossa família. Logo, há na família a santidade dos reis, os quais são muito poderosos entre os homens, e a religião dos deuses, aos quais os próprios reis estão sujeitos."

2. In Corneliae autem locum Pompeiam duxit Quinti Pompei filiam, L. Sullae neptem; cum qua deinde diuortium fecit adulteratam opinatus a Publio Clodio, quem inter publicas caerimonias penetrasse ad eam muliebri ueste tam constans fama erat, ut senatus quaestionem de pollutis sacris decreuerit.

No lugar de Cornélia, tomou por esposa Pompeia, filha de Quinto Pompeu, neta de L. Sila; da qual se separou em seguida, julgando que ela cometera adultério com Públio Clódio, a fama de que ele se insinuara para ela, durante uma cerimônia pública com veste feminina, era tão consistente que o senado decretou um inquérito a respeito da profanação das coisas sagradas.

14. Praetor creatus, detecta coniuratione Catilinae senatuque uniuerso in socios facinoris ultimam statuente poenam, solus municipatim diuidendos custodiendosque publicatis bonis censuit. Quin et tantum metum iniecit asperiora suadentibus, identidem ostentans quanta eos in posterum a plebe Romana maneret inuidia, ut Decimum Silanum consulem designatum non piguerit sententiam suam, quia mutare turpe erat, interpretatione lenire, uelut grauius atque ipse sensisset exceptam.

Eleito pretor quando foi descoberta a conjuração de Catilina e estabelecida pelo senado inteiro a pena de morte para os aliados do crime, somente ele determinou que, tendo os bens confiscados, eles fossem divididos pelos municípios e lá presos. E, além disso, suscitou tanto medo aos que propuseram coisas mais severas, mostrando a eles quanto ódio por parte da plebe romana se conservaria no futuro, que Décimo Silano, cônsul designado, porque seria vergonhoso mudar sua opinião, não teria se envergonhado de abrandar sua interpretação, como se tivesse percebido que sua opinião foi recebida como algo mais grave.

2. Obtinuisset adeo transductis iam ad se pluribus et in his Cicerone consulis fratre, nisi labantem ordinem confirmasset $M$. Catonis oratio. Ac ne sic quidem impedire rem destitit, quoad manus equitum Romanorum, quae armata praesidii causa circumstabat, inmoderatius perseueranti necem comminata est, etiam strictos gladios usque eo intentans, ut sedentem uma proximi deseruerint, uix pauci complexu togaque obiecta protexerint. Tunc plane deterritus non modo cessit, sedet in reliquum anni tempus curia abstinuit.

E teria ganhado com os muitos que passaram para seu lado, e dentre eles Cícero, irmão do cônsul, se o discurso de M. Catão não restabelecesse a ordem cambaleante. E nem sequer assim desistiu de opor-se a isso, até que um exército armado de cavaleiros romanos que protegiam aquele posto ameaçou de morte o insistente desmedido, até 
mesmo lhe ameaçando com os gládios empunhados, de modo que aqueles sentados próximos dele o abandonaram, apenas uns poucos o protegeram com um cerco e com a toga lançada diante dele. Então, claramente assustado, não só se retirou, mas também se afastou da cúria o restante do ano.

31. Cum ergo sublatam tribunorum intercessionem ipsosque urbe cessisse nuntiatum esset, praemissis confestim clam cohortibus, ne qua suspicio moueretur, et spectaculo publico per dissimulationem interfuit et formam, qua ludum gladiatorum erat aedificaturus, considerauit et ex consuetudine conuiuio se frequenti dedit.

Logo que se anunciou que a intervenção dos tribunos fora suprimida e que eles saíram da urbe, imediatamente, mandou as tropas furtivamente, movendo-se sem levantar suspeita; então assistiu a um espetáculo público para disfarçar, examinou a planta do que seria construído para a escola de gladiadores e, como de costume, compareceu a um frequentado banquete.

2. Dein post solis occasum mulis e proximo pistrino ad uehiculum iunctis occultissimum iter modico comitatu ingressus est; et cum luminibus extinctis decessisset uia, diu errabundus tandem ad lucem duce reperto per angustissimos tramites pedibus euasit. Consecutusque cohortis ad Rubiconem flumen, qui prouinciae eius finis erat, paulum constitit, ac reputans quantum moliretur, conuersus ad proximos: "Etiam nunc," inquit, "regredi possumus; quod si ponticulum transierimus, omnia armis agenda erunt."

Em seguida, depois do pôr-do-sol, começou uma viagem secretíssima com um pequeno cortejo, tendo juntado ao veículo mulas de um moinho vizinho; e, com as luzes apagadas, afastou-se do trajeto durante muito tempo, ao amanhecer, encontrando um guia, saiu a pé pelos atalhos mais estreitos. Alcançou suas tropas no rio Rubicão, que era a fronteira de sua província, parou um pouco e, refletindo acerca do quanto estava fazendo, voltado para aqueles que estavam próximos, ele disse: "Até agora podemos retroceder; porém, se atravessarmos a pequena ponte, tudo será feito pelas armas".

37. Confectis bellis quinquiens triumphauit, post deuictum Scipionem quater eodem mense, sed interiectis diebus, et rursus semel post superatos Pompei líberos. Primum et excellentissimum triumphum egit Gallicum, sequentem Alexandrinum, deinde Ponticum, huic proximum Africanum, nouissimum Hispaniensem, diuerso quemque apparatu et instrumento.

Terminadas as guerras, cinco vezes triunfou, quatro depois de ter vencido Cipião no mesmo mês, mas em dias intercalados, e mais uma vez depois de subjugar os filhos de Pompeu. O triunfo gálico foi o primeiro e o mais notável, seguido do alexandrino, depois, o do Ponto, próximo deste o africano, o hispaniense foi o último, cada um distinto no preparo e nos instrumentos. 
2. Galici triumphi die Velabrum praeteruehens paene curru excussus est axe diffracto ascenditque Capitolium ad lumina, quadraginta elephantis dextra sinistraque lychnuchos gestantibus. Pontico triumpho inter pompae fercula trium uerborum praetulit titulum VENI. VIDI. VICI non acta belli significantem sicut ceteris, sed celeriter confecti notam.

No dia do triunfo gálico, atravessando o Velabro, quase foi derrubado por causa do eixo quebrado do carro, e subiu ao Capitólio à luz de lâmpadas por quarenta elefantes transportadas, do lado direito e esquerdo. No triunfo do Ponto, entre os andores da procissão, ele levou a inscrição de três palavras "Vim, vi, venci", significando não os feitos de guerra, assim como nos outros, mas a maneira rápida com que foram executados.

44. Nam de ornanda instruendaque urbe, item de tuendo ampliandoque imperio plura ac maiora in dies destinabat: in primis Martis templum, quantum nusquam esset, exstruere repleto et conplanato lacu, in quo naumachiae spectaculum ediderat, theatrumque summae magnitudinis Tarpeio monti accubans; 2. ius ciuile ad certum modum redigere atque ex immensa diffusaque legum copia optima quaeque et necessaria in paucissimos conferre libros; bibliothecas Graecas Latinasque quas maximas posset publicare data Marco Varroni cura comparandarum ac digerendarum; 3. siccare Pomptinas paludes; emittere Fucinum lacum; uiam munire a mari Supero per Appennini dorsum ad Tiberim usque; perfodere Isthmum; Dacos, qui se in Pontum et Thraciam effuderant, coercere; mox Parthis inferre bellum per Armeniam minorem nec nisi ante expertos adgredi proelio.

Com efeito, ele resolvia mais projetos e maiores cada dia, para ornar e preparar a cidade, do mesmo modo, para proteger e aumentar o império: primeiramente, construir o templo de Marte, grande como jamais existira, enchendo e aplainando o lago no qual produzira o espetáculo do combate naval, e também um teatro de suprema magnitude encostado à rocha Tarpeia; reduzir o direito civil para uma certa quantidade e, da imensa e difusa abundância de leis, reunir aquelas que são as melhores e necessárias em pouquíssimos livros; abrir ao público as maiores bibliotecas gregas e latinas que fosse possível, a incumbência de adquiri-las e classificá-las foi dada a Marcos Varrão; secar os brejos pontinos; abrir uma comporta no lago Fucino; construir um caminho do mar adriático pelo cume dos Apeninos até o Tibre; abrir um canal no istmo; conter os Dacos, que se espalharam pelo Ponto e pela Trácia; em seguida, fazer guerra aos partos pela Armênia Menor, mas não os atacar antes de terem experimentado um combate.

4. Talia agentem atque meditantem mors praeuenit. De qua prius quam dicam, ea quae ad formam et habitum et cultum et mores, nec minus quae ad ciuilia et bellica eius studia pertineant, non alienum erit summatim exponere.

A morte se antecipou à realização e ao preparo de tais projetos. Antes que eu fale a respeito disso, não será impróprio expor sucintamente a respeito da aparência, da vestimenta, do modo de viver 
e dos costumes, assim como dos seus trabalhos concernentes às coisas civis e bélicas.

45. Fuisse traditur excelsa statura, colore candido, teretibus membris, ore paulo pleniore, nigris uegetisque oculis, ualitudine prospera, nisi quod tempore extremo repente animo linqui atque etiam per somnum exterreri solebat. Comitiali quoque morbo bis inter res agendas correptus est.

Diz-se que era de elevada estatura, cor branca, membros proporcionais, rosto um pouco mais cheio, olhos negros e vivos, de boa saúde, a não ser nos últimos tempos em que costumava desmaiar repentinamente e era aterrorizado por pesadelos durante o sono. Ele também foi acometido duas vezes pela epilepsia durante suas atividades.

2. Circa corporis curam morosior, ut non solum tonderetur diligenter ac raderetur, sed uelleretur etiam, ut quidam exprobrauerunt, caluitii uero deformitatem iniquissime ferret, saepe obtrectatorum iocis obnoxiam expertus. Ideoque et deficientem capillum reuocare a uertice adsueuerat et ex omnibus decretis sibi a senatu populoque honoribus non alius aut recepit aut usurpauit libentius quam ius laureae coronae perpetuo gestandae.

Era muito exigente com o cuidado do corpo que não apenas cortava o cabelo e se barbeava diligentemente, mas também se depilava, por isso alguns o censuravam; mas apresentava a deformidade da calvície com o maior constrangimento, frequentemente, ele soube, sujeita aos gracejos dos difamadores. E por isso acostumara-se a puxar o ralo cabelo para a frente da cabeça e, de todas as honras que lhe foram destinadas pelo senado e pelo povo, nenhuma outra recebeu ou usou com mais satisfação do que o direito de portar a coroa de louro sempre.

3. Etiam cultu notabilem ferunt; usum enim lato clauo ad manus fimbriato nec unquam aliter ut supere eum cingeretur, et quidem fluxiore cinctura; unde emanasse Sullae dictum optimates saepius admonentis, ut male praecintum puerum cauerent.

Conta-se também que era notável no traje; com efeito, usava um laticlavo franjado até as mãos e sempre o cingia com cinto, na verdade, de cintura larga; daí originou-se o dito de Sila aos nobres que, muito frequentemente, eram advertidos para que tomassem cuidado com o garoto mal cingido.

55. Eloquentia militarique re aut aequauit praestantissimorum gloriam aut excessit. Post accusationem Dolabellae haud dubie principibus patronus adnumeratus est. Certe Cicero ad Brutum oratores enumerans negat se uidere, cui debeat Caesar cedere, aitque eum elegantem, splendidam quoque atque etiam magnificam et generosam quodam modo rationem dicendi tenere; et ad Cornelium Nepotem de eodem ita scripsit: 
$\mathrm{Na}$ eloquência e no serviço militar igualou ou excedeu a glória dos mais notáveis. Depois da acusação contra Dolabela, certamente, foi incluído entre os principais defensores. Cícero, seguramente, ao enumerar os oradores em Brutus, nega haver alguém a quem César ficasse atrás, e diz que ele tem um método de discursar elegante, brilhante e também magnífico e nobre de alguma maneira; e a respeito dele escreveu para Cornélio Nepos assim:

2. "Quid? Oratorem quem huic antepones eorum, qui nihil aliud egerunt?Quis sententiis aut acutior aut crebrior? Quis uerbis aut ornatior aut elegantior?" Genus eloquentiae dumtaxat adulescens adhuc Strabonis Caesaris secutus uidetur, cuius etiam ex oratione, quae inscribitur "pro Sardis," ad uerbum nonnula transtulit in diuinationem suam. Pronuntiasse autem dicitur uoce acuta, ardenti motu gestuque, non sine uenustate.

"O quê? Que orador preferes a este dentre aqueles que não fizeram mais nada? Quem é mais agudo ou abundante nas sentenças? Quem é nas palavras mais ornado ou elegante?" Pelo menos quando adolescente parece ter seguido até então o gênero da eloquência de César Estrabão e de quem transcreveu, literalmente, do discurso intitulado "Pelos Sardos" algumas coisas para sua adivinhação. Além disso, diz-se que pronunciava com aguda voz, com movimento e gesto inflamados, com graça.

3. Orationes aliquas reliquit, inter quas temere quaedam feruntur. "Pro Quinto Metello" non immerito Augustus existimat magis ab actuariis exceptam male subsequentibus uerba dicentis, quam ab ipso editam; nam in quibusdam exemplaribus inuenio ne inscriptam quidem "pro Metello," sed "quam scripsit Metello," cum ex persona Caesaris sermos sit Metellum seque aduersus communium obtrectatorum criminationes purgantis.

Ele deixou alguns discursos, entre os quais uns são atribuídos ao acaso. Augusto julga com razão que "Por Quinto Metelo" foi antes escrito por copistas que mal seguem as palavras que ele diz, do que o publicado por ele mesmo; pois, seguramente, nem encontro em certos exemplares o título "Por Metelo", mas "o que escreveu para Metelo", ainda que o discurso fosse do próprio César para Metelo e para si mesmo, dissipando as acusações dos seus difamadores em comum.

4. "Apud milites" quoque "in Hispania" idem Augustus uix ipsius putat, quae tamen duplex fertur: una quase priore habita proelio, altera posteriore, quo Asinius Pollio ne tempus quidem contionandi habuisse eum dicit subita hostium incursione.

O próprio Augusto também julga que dificilmente é dele "Aos soldados na Hispânia", contudo, dois discursos lhe são atribuídos: um tido como no primeiro combate, o outro no segundo, do qual Asínio Polião diz que ele não teve, na verdade, nem tempo para discursar por causa do ataque repentino dos inimigos. 
57) Armorum et equitandi peritissimus, laboris ultra fidem patiens erat. In agmine nonnunquam equo, saepius pedibus anteibat, capite detecto, seu sol seu imber esset; longissimas uias incredibili celeritate confecit, expeditus, meritoria raeda, centena passuum milia in singulos dies; si flumina morarentur, nando traiciens uel innixus inflatis utribus, ut persaepe nuntios de se praeuenerit.

O mais hábil nas armas e na equitação, que suportava o trabalho além do normal. Durante a marcha, caminhava adiante, por vezes no cavalo, mais frequentemente a pé, com a cabeça descoberta, estivesse sol ou chuva; terminou os mais longos caminhos numa velocidade incrível, leve, em carro alugado, cada dia cem mil passos; se os rios o impediam, atravessava a nado ou apoiado sobre odres inflados, de modo que, muitas vezes, antecipava-se aos seus mensageiros.

72) Amicos tanta semper facilitate indulgentiaque tractauit, ut Gaio Oppio comitanti se per siluestre iter correptoque subita ualitudine deuersoriolo eo, quod unum erat, cesserit et ipse humi ac sub diuo cubuerit. Iam autem rerum potens quosdam etiam infimi generis ad amplissimos honores prouexit, cum ob id culparetur, professus palam, si grassatorum et sicariorum ope in tuenda sua dignitate usus esset, talibus quoque se parem gratiam relaturum.

Sempre tratou os amigos com tamanha bondade e indulgência que quando o acompanhante Caio Ópio foi acometido por uma súbita doença no caminho da floresta, cedeu a ele o único alojamento e ele próprio deitou no chão e no sereno. Além disso, já soberano das coisas, levou algumas pessoas de ínfima origem para as mais importantes magistraturas, visto que era censurado por isso, anunciou publicamente que se tivesse se servido de ladrões e de assassinos na proteção de sua dignidade, também a estes agradeceria igualmente.

88) Periit sexto et quinquagensimo aetatis anno atque in deorum numerum relatus est, non ore modo decernentium sed et persuasione uolgi. Siquidem ludis, quos primos consecrato ei heres Augustus edebat, stella crinita per septem continuos dies fulsit exoriens circa undecimam horam, creditumque est animam esse Caesaris in caelum recepit; et hac de causa simulacro eius in uertice additur stella.

Curiam, in qua occisus est, obstrui placuit Idusque Martias Parricidium nominari, ac ne unquam eo die senatus ageretur.

Morreu aos cinquenta e seis anos de idade e foi incluído entre os deuses, não só pela boca daqueles que decidiram, mas também pela convicção do povo. Visto que durante os jogos, os primeiros que o herdeiro Augusto fez na sua divinização, um cometa brilhou por sete dias seguidos, aparecendo em torno das onze horas, admitiu-se a crença de que era a alma de César no céu; e, por causa disso, uma estrela foi acrescentada na cabeça de sua estátua.

Resolveu-se que fosse fechada a cúria na qual ele foi assassinado, os idos de março fossem chamados "parricídio" e o senado nunca trabalharia nesse dia. 
A bíos ou uita atualmente corresponde ao gênero biográfico, porém, não adotaremos estritamente a terminologia contemporânea como correspondente, pois implicaria em aspectos que não são próprios do gênero antigo. Isso não nos impede de empregar "gênero biográfico" desde que lembremos que não estamos tratando do gênero como ele se apresenta hoje.

A uita constitui um gênero próprio, mas apresenta certo parentesco com a história: ambas são narrativas acerca de temas importantes, a uita se diferencia ao narrar a vida de uma pessoa, o que permite produzir um quadro com aspectos diversos, pois não se limita como na monografia às características pertinentes ao acontecimento principal. É possível discorrer acerca da vida do indivíduo desde seu nascimento e prosseguir até sua morte, ainda que isso não seja de extrema relevância para seus feitos; fatos talvez considerados não tão relevantes, como a conduta amorosa, também podem ser mencionados.

Aristóteles distingue dois tipos de elogio em sua Retórica:

O elogio (epaínos) é um discurso que manifesta a grandeza de uma virtude. É, por conseguinte, necessário mostrar que as ações são virtuosas. Mas o encómio refere-se às obras [...] E por isso fazemos o encómio de quem realizou algo. [...] $\mathrm{O}$ elogio e os conselhos pertencem a uma espécie comum; pois o que se pode sugerir no conselho, torna-se encómio quando muda a forma de expressão ${ }^{124}$. (I, $9,1367 b)$

É possível inferir que a história como discurso epidítico aproxima-se mais do encômio $^{125}$. Ainda assim, conforme observamos na monografia, as virtudes das personagens também interessam, mas até o ponto em que contribuem para a narrativa. Ao passo que a uita engloba os dois tipos de elogio, pois tratará das características de um indivíduo cujos feitos tiveram importância histórica; os feitos, portanto, fazem parte do repertório biográfico, mas não constituem o centro da narrativa.

A écfrase ocorre no gênero biográfico com a mesma finalidade apresentada na monografia: retratar um indivíduo. Algumas partes são essencialmente descritivas, o caráter estático ou dinâmico depende do assunto de cada capítulo. A etopeia, tipo de

\footnotetext{
${ }^{124}$ Cf. nota 1.

${ }^{125}$ AMBROSIO faz afirmação semelhante na op. cit. na nota 117. Cf. pp.82: "Esses que antepõem os feitos às virtudes talvez sejam os autores de história, que escrevem encómion, que se limitam às obras, à ação daquele a quem se poderia elogiar ou censurar, que fazem a explicatio rerum."
} 
écfrase estudada na monografia que se concentra no caráter, é aqui uma dentre inúmeras utilizadas no decorrer da narrativa, pois não se quer apenas produzir um retrato moral do indivíduo, mas apresentar todos os aspectos concernentes a ele.

Para essa pesquisa selecionamos algumas passagens do Divino Júlio de Suetônio, a primeira biografia do De Vita Caesarum. O autor narra fatos da vida pública e particular do retratado, além de descrevê-lo fisicamente, moralmente e também na vida militar.

A descrição de César não discorre tão somente acerca de suas qualidades e grandes feitos, como também acerca de aspectos considerados negativos, mencionando fatos da vida privada que maculam sua imagem. Ao citar rumores, Suetônio passa por eles sem demonstrar juízos de valor, aparentando imparcialidade, além disso, não se prolonga muito em tais questões, conduzindo o leitor para outros assuntos. É o que ocorre, por exemplo, no capítulo 2, ao insinuar um possível relacionamento com Nicomedes, o rei da Bitínia.

Assumindo a tipologia estabelecida na Retótica a Herênio, todos os elementos da descrição compõem a obra, que expomos a seguir.

\section{Coisas externas}

No primeiro capítulo tomamos conhecimento de dois casamentos, o segundo deles com Cornélia, causando-lhe desentendimento com Sila e que lhe rendeu algumas privações. No capítulo 6, sabemos do outro casamento, com Pompeia, da qual se separou por desconfiar de adultério, embora a narrativa não afirme que ela o traiu, mas apenas que foi cortejada por Clódio.

Vemos também que era possuidor de amigos influentes que intervieram junto a Sila. No capítulo 72, é descrito como um amigo fiel, mas suas relações com pessoas de origem humilde o desqualificam.

A origem divina é ressaltada no capítulo 6, durante o discurso do próprio César no funeral de sua tia. Ele exalta sua linhagem - a fortuna aqui lhe parece favorável, contudo, sua linhagem é questionada no capítulo anterior quando Suetônio cita a declaração de Sila "há em César muitos Mários", este, por sua vez, não era de origem nobre e há entre eles um grau de parentesco.

No capítulo 14 temos que César foi pretor na época da conspiração de Catilina. Apresentado como alguém influente e engenhoso, por meio de um discurso, quase convenceu o senado a não condenar os envolvidos, no entanto, prevaleceu a opinião de 
Catão. Na sequência aparece a cena em que ele é ameaçado após a insistente oposição, embora breve, detalha-se o suficiente para elaborar um quadro ao leitor:

[...] lhe ameaçando com os gládios empunhados, de modo que aqueles sentados próximos dele o abandonaram, apenas uns poucos o protegeram com um cerco e com a toga lançada diante dele.

A cena acontece muito rapidamente diante do leitor, mas conforme os preceitos da evidência, a ameaça de morte não é apenas mencionada (o que seria comum na narrativa), temos uma progressão temporal com base na descrição das ações que compõem a cena.

Os desfiles triunfais são destacados no capítulo 37: a enumeração dos triunfos realça a importância das vitórias e suas celebrações, demonstrando seu poder bélico; dentre os cinco que são citados, dois ganham destaque por meio da narração de um fato.

O triunfo da Gália menciona a peculiaridade do carro quebrado que quase o derrubou, um acontecimento que apresenta certa comicidade, no entanto, a exaltação do desfile é retomada rapidamente ao descrever a subida de César ao Capítólio, sob as luzes transportadas pelos elefantes, um elemento visual que realça o efeito sobre o leitor - uma cena breve que fornece elementos visuais suficientes para suscitar a imaginação. O triunfo do Ponto é também destacado, uma vez que nessa ocasião ele levou a célebre inscrição "Vim, vi, venci" consigo.

Ressalta-se sua erudição tanto quanto sua capacidade militar. Durante seu império fez notáveis mudanças em Roma, que são enumeradas no capítulo 44, as quais não ficaram restritas a construções, o direito civil foi revisto e grandes bibliotecas foram construídas, com rico e variado acervo.

No capítulo 55, afirma-se sua capacidade como orador; para realçar suas qualidades elas são enunciadas por meio de um elogio de Cícero (Brutus, 1xxv, 261), por este considerado o melhor em todos os aspectos necessários ao orador, inclusive na actio. Na Conjuração de Catilina, vemos César representado também como grande orador quando discursa ao senado na passagem que antecede seu retrato (capítulo 51), servindo como contraponto ao discurso de Catão. Esse mesmo discurso exposto na monografia de Salústio é citado no capítulo 14, onde o vemos ser ameaçado por algumas pessoas; na biografia apenas se narra brevemente, embora a cena da ameaça de morte seja bem descrita, ao passo que na monografia o discurso ocupa todo o capítulo e 
a ameaça é narrada anteriormente, explicando tratar-se de uma artimanha de Q. Catulo e C. Pisão.

\section{$\underline{\text { Corpo }}$}

O capítulo 45 é dedicado à descrição física de César, prevalece a enumeração das características, o estado de saúde e a maneira de se vestir.

A expressão "ore paulo pleniore" levanta alguns questionamentos, o teórico Monroe $^{126}$ afirma que a tradução "rosto um pouco mais cheio" não condiz com as representações imagéticas (moedas e esculturas) que o apresentam com aspecto magro. O autor procura explicar e propõe que poderia significar "expressão" em vez de "face, rosto" e o adjetivo seria, na verdade, "leniore", mudando o sentido para algo como "gentil".

A tradução de Antonio da Silveira Mendonça está assim: "faces um pouco mais cheias”. John Carew Rolfe, na tradução inglesa da edição consultada para o texto original, assim traduz: "a somewhat full face"127.

As representações imagéticas são amplamente divulgadas, as moedas, por exemplo, estão sempre circulando. As imagens na Antiguidade serviam como eficiente instrumento de propaganda ${ }^{128}$, portanto, podemos inferir que a figura de César poderia ser idealizada nesse tipo de representação. Ao passo que a obra de Suetônio, sem esse caráter propagandista e aparentemente fiel à realidade, daria preferência às características conhecidas como verdadeiras. Isso justificaria a divergência entre a caracterização no meio verbal e visual.

Se se tratasse de um elogio dedicado a enaltecer apenas suas qualidades, as imperfeições físicas seriam excluídas, entretanto, aparentando imparcialidade, o autor procura produzir uma imagem verdadeira, em razão disso, o autor expõe até mesmo a calvície:

[...] apresentava a deformidade da calvície com o maior constrangimento [...] acostumara-se a puxar o ralo cabelo para a frente da cabeça e, de todas as honras que lhe foram destinadas pelo senado e pelo povo, nenhuma outra recebeu ou usou com mais satisfação do que o direito de portar a coroa de louro sempre.

\footnotetext{
${ }^{126}$ MONROE, E. D. “Concerning Casar's Appearance”. In: The Classical Journal. 1917, vol.12, n44, pp.247-53.

27 MENDONÇA, A.S. Vidas de César. Suetônio. São Paulo: estação Liberdade. 2007; The Lives of the Caesars. Trad. J. C. Rolfe. London: Loeb Classical Library.1989, vol.I.

${ }^{128}$ Cf. MARTINS, P. Imagem e Poder: Considerações Sobre a Representação de Otávio Augusto. São Paulo: FFLCH/USP. 2003. (Tese de Doutorado).passim.
} 
A deformidade não contribui para a formação de um éthos favorável, no entanto, logo o foco da descrição muda para sua vestimenta.

A enumeração de habilidades no capítulo 57 contribui para a amplificação de sua capacidade, afinal, são poucas as atividades mencionadas, mas a habilidade em todas é bastante destacada. Visualizamos um homem dotado grande de vigor físico; uma particularidade serve para ressaltar esse aspecto e parece até exagerada: ele seria capaz de chegar antes mesmo de seus próprios mensageiros.

\section{$\underline{\hat{A} \operatorname{nimo}}$}

Em razão do gênero que, como comentamos, trata não apenas das virtudes, como também dos feitos, as qualidades do ânimo se inserem sobretudo em contextos que tratam de suas ações, reforçando seu engenho, por exemplo, no campo bélico. A destreza militar já é ressaltada em conjunto com as habilidades físicas. Nas monografias de Salústio, as disposições do ânimo recebem tratamento diferenciado, como constituintes primordiais do éthos, visto que as obras têm caráter exemplar.

No capítulo 31, são relatados alguns artifícios utilizados por Júlio César antes do conflito para despistar seus oponentes, demonstrando domínio das estratégias militares. De fato, é seu poder militar que o levará a ser o aclamado e divinizado imperador.

As qualidades do corpo também se misturam às qualidades do ânimo, no capítulo 57, pois sua resistência física associa-se a sua obstinação, capaz mesmo de superar limites. A enumeração das obras em Roma, no capítulo 44, amplifica pela quantidade de projetos apresentados - tantos que nem conseguiu concluir antes de sua morte - e reforça o caráter obstinado e ambicioso, uma vez que seus projetos eram grandiosos.

A generosidade, qualidade que ganha destaque na caracterização de Salústio, transparece no capítulo 72 por meio de sua atitude em relação às amizades, capaz de dormir ao relento para que o amigo doente tivesse abrigo.

$$
* * *
$$

No capítulo 88, praticamente no desfecho da uita, narra-se a morte de César, aqui Suetônio introduz um elemento mítico.

O modo como ele morreu só é mencionado no próximo capítulo, o que se destaca é sua apoteose: um cometa brilhou durante os jogos fúnebres em sua homenagem, já divinizado pela população na ocasião de sua morte, acreditava-se ser sua alma, razão pela qual uma estrela foi colocada na sua estátua. 
Para o teórico Gurval ${ }^{129}$ o mito do cometa, formado muito depois da morte do imperador, não deve ser visto como algo fortuito, sua aparição, quer seja fato ou ficção, deve ser entendida como clara manifestação da ideologia política de Augusto.

Em razão de toda a obra produzir o retrato de César, apenas algumas passagens foram selecionadas para ilustrar os procedimentos utilizados. A análise verbal das passagens, contudo, não é suficiente para indicar se há um padrão de uso na obra inteira; como as demais obras analisadas tinham a écfrase bem delimitada, nelas era possível estabelecer alguns parâmetros.

Dentre as partes do Divino Júlio expostas acima, selecionamos duas para uma breve análise verbal inseridas no contexto claro de descrição.

O primeiro capítulo introduz o retrato de César discorrendo principalmente acerca de sua origem e relações, conhecemos um inimigo de juventude, Sila, e sabemos que já estava investido do sacerdócio. Enfim, uma série de eventos que produzem um quadro geral da vida de César.

Há dois tempos verbais predominantes, um deles é o pretérito perfeito do indicativo que indica ações acabadas e bem pontuais, pois o autor não se detém nelas, sobretudo no primeiro parágrafo onde a trajetória dos fatos é muito rápida. $\mathrm{O}$ outro tempo é o imperfeito do subjuntivo, cuja ação é durativa, a maior frequência desse tempo no último parágrafo justifica o modo subjuntivo ao discorrer acerca das suposições de Sila com relação a César.

Sullam [...] expugnatum tandem proclamasse siue diuinitus siue aliqua coniectura: uincerent ac sibi haberent, dum modo scirent eum, quem incolumen tanto opere cuperent, quandoque optimatum partibus, quas secum simul defendisset, exitio futurum [...]

Sila [...] finalmente, vencido, proclamou por vontade divina ou por alguma outra conjetura: que venciam e o tivessem, contanto que soubessem que ele, quem, com tanto trabalho desejavam incólume, um dia, seria a ruína do partido dos nobres [...]

O capítulo 45 é dedicado à descrição física - ou segundo a classificação da écfrase, à prosopografia - é, portanto, uma sequência bastante descritiva. Os tempos verbais predominantes são os mesmos da passagem supracitada. O imperfeito do

\footnotetext{
${ }^{129}$ Cf. nota 102.
} 
subjuntivo ocorre com frequência em oração subordinada consecutiva ao elencar os cuidados de César com o corpo.

2. Circa corporis curam morosior, ut non solum tonderetur diligenter ac raderetur, sed uelleretur etiam, ut quidam exprobrauerunt, caluitii uero deformitatem iniquissime ferret, saepe obtrectatorum iocis obnoxiam expertus.

Era muito exigente com o cuidado do corpo que não apenas cortava o cabelo e se barbeava diligentemente, mas também se depilava, por isso alguns o censuravam; mas apresentava a deformidade da calvície com o maior constrangimento, frequentemente, ele soube, sujeita aos gracejos dos difamadores. 


\section{Considerações Finais}

A proposta que se colocava no princípio dessa pesquisa era diferenciar a écfrase da evidência. Por meio não apenas da teoria antiga, que fundamenta com autoridade, como também por meio da análise de textos é que foi possível afirmar que se trata de dois mecanismos cuja relação é intrínseca, contudo, comprovadamente não são equivalentes.

A associação do meio visual com a linguagem verbal norteia o princípio da evidência ou da enargia, em razão da força atribuída ao sentido da visão. A écfrase constitui na retórica o procedimento adequado à presentificação do discurso; as três funções retóricas são muito bem cumpridas pela écfrase acompanhada da enargia.

O caráter digressivo da descrição pode nos levar equivocadamente a pensar que o deleite seja o fim mais apropriado, entretanto, observamos que opera também o docere e o mouere dependendo do contexto na qual se insere. A Eneida, por exemplo, se imaginarmos a época de sua composição, é inevitável a conexão entre o conteúdo da obra e o elogio a Augusto - o tema das écfrases desse poema costuma remeter à grandiosidade da estirpe de Eneias, cujo protagonista no canto VIII é Otávio. A exaltação de Augusto deleita e comove o público, que verá na sua figura um homem superior e representante dos romanos.

A monografia e a uita mostraram-se importantes para ensinar: a primeira traz modelos de conduta, ao passo que a segunda, sem caráter exemplar, discorre a respeito de uma figura louvável.

Em todos os casos, a écfrase ou descrição constitui o dispositivo básico não apenas para detalhar, mas para ressaltar os aspectos desejados pelo autor. Principalmente nas ocorrências de maior extensão, produz-se mais do que um retrato estático, é possível entrever ações, desejos, emoções, enfim, elementos que vemos hoje como típicos da narração.

Embora nossas conclusões estejam sob a influência do pensamento moderno que enxerga a descrição de maneira distinta, isolando-a da narração, procuramos aqui nos ater ao princípio de que ela poderia integrar a narrativa sem necessariamente subordinar-se à narração, como mero acessório.

Não bastasse a tradicional confusão entre écfrase e evidência, descortinamos algumas variações terminológicas para os conceitos ao expor algumas teorizações 
antigas. Obviamente queremos sempre resolver as divergências e delimitar as diferenças para cada termo, no entanto, com a compreensão do processo, não é indispensável que se estabeleça uma teoria criteriosa. Se fizermos isso, corremos o risco de artificializar dispositivos que são frequentes e se inter-relacionam, portanto, não ocorrem isoladamente. A écfrase funciona melhor ao produzir a enargia e essa, por sua vez, depende de exercícios inerentes ao indivíduo, como a fantasia.

A fantasia no sentido aristotélico de imaginação é um mecanismo necessário à evidência, pois ela fornece a imagem do nosso próprio repertório. A écfrase detalhada possibilita o exercício imagético, uma vez que construímos o "objeto" simultaneamente a sua pormenorização. Para os estóicos a fantasia vai além, entendida como representação dos objetos, é um critério epistemológico que diferencia representações verdadeiras das falsas.

O consenso nos leva a compreender a fantasia como um processo anímico, mas no tratado Do Sublime a fantasia funciona como dispositivo retórico para produzir imagens, equivalendo à evidência.

Outra dificuldade recorrente no estudo dos mecanimos descritivos é seu estatuto. A definição retórica dos Progymnásmata parece bastante apropriada, pois se trata de um tipo de composição; algumas espécies da descrição, por assim dizer, são figuras na tradição retórica, reforçando, portanto, a amplitude da descrição, visto que sua constituição é complexa e variada.

A evidência ou enargia já apresenta a condição de figura em Quintiliano e assim parece estabelecer-se na retórica. O principio da evidência, no entanto, como vimos, assemelha-se aos fenômenos anímicos, levando-nos a acreditar que seja mais do que figura, pois dispor diante dos olhos não é tarefa simples para uma única figura.

Reforçamos, portanto, o que já propúnhamos logo no início do trabalho: é indispensável para a compreensão dos mecanismos estudá-los na obra em que se manifestam e em conjunto com seus propósitos. A classificação categórica não é possível, de qualquer forma, pertencendo ao campo da retórica e da poética, os procedimentos são extremamente ricos e se adaptam aos objetivos do orador ou do poeta. 


\section{Bibliografia}

\section{REFERÊNCIAS ANTIGAS}

[ANÔNIMO]. Retórica a Herênio. Trad. Adriana Seabra \& A. P. Celestino Faria. C. São Paulo: Hedra, 2005.

AQUILES TÁCIO. Leucipa e Clitofonte. Trad. Máximo Brioso Sanches \& Emilio Crespo. Madri: Gredos. 1982, vol.56.

ARISTÓTELES. De Anima. Trad. Maria Cecília Gomes dos Reis. São Paulo: Editora 34. 2006.

Metafísica. Trad. Valentín Garcia Yebra. Madri: Gredos. 1996, vol. I.

On The Soul; Parva Naturalia. In: Arostotle. Trad. W. S. Hett. London:

Loeb Classical Library. 1975, vol. VIII.

Poética. Trad. Eudoro de Souza. São Paulo: Ars Poetica. 1973.

Política. Trad. Mário da Gama Kury. Brasília: Editora da Universidade de Brasília. 1985.

Retórica. Trad. Manuel Alexandre Júnior, Paulo F. Alberto e Abel do N. Pena. Lisboa: Casa da Moeda. 1998. [s.d.]

The Works of Aristotle. Trad. W.D. Ross J. J. Smith. London: Oxford, vol.3.

[CATULO] O Livro de Catulo. Trad. João Angelo Oliva Neto. São Paulo: Edusp. 1996.

CÍCERO. De Natura Deorum. Academica. Trad. H. Rackam. London: Loeb classical Library. 1979.

De Inuentione. De optimo genere oratorum. Trad. H. M. Hubell. London: Loeb Classical Library. 1976.

De Oratore. Trad. E. W. Sutton \& H. Rackam (v.2). London: Loeb Classical Library.1992.

Orator. Trad. H. M. Hubell. London: Loeb Classical Library. 1992.

Partitione Oratoria. Trad. H. Rackam. London: Loeb classical Library. 1992.

Sobre el orador. Trad. José Javier Isso. Madri: Gredos. 2002.

Sobre La Partición Oratória de Marco Túlio Cicerón. Trad. Bulmaro R. Coria. México: Universidad Nacional Autônoma. 1987.

CHRYSIPPUS. Oeuvre Philosophique. Trad. Richard Dufour. Paris : Belles lettres. 2004

DEMETRIUS. On Style. Tradução Doreen C. Innes. London: Loeb classical Library. 1995.

[DIVERSOS] Rhetores Latini Minores. Códice de Carolus Halm.

EURIPIDES. Electra. Trad. M.J. Cropp. Warminster: Aris \& Phillips. 1988. 
HALICARNASSUS, D. The Roman Antiquities of Dionysius of Halicarnassus. Trad. Earnest Cary. London: Loeb Classical Library. 1948.

HESÍODO. Escudo de Heracles. Trad. de Jaa Torrano. In: Hypnos. 2000. Ano 5, nº, pp.185-221.

HOMERO. Ilíada. Trad. Carlos Alberto Nunes. Rio de Janeiro. Ediouro. 2001, 2.edição.

Odisséia. Trad. Carlos Alberto Nunes. Rio de Janeiro. Ediouro. 2001.

HORÁCIO. Arte Poética. Trad. R. M. Rosado Fernandes. Lisboa: Inquérito, 1984.

LAERTIOS, Diógenes. Vidas e doutrinas dos filósofos ilustres. Tradução de Mário da Gama Kury. Brasília: Editora UNB. 1997.

LONGINO. Do Sublime. In: A Poética Clássica. Trad. Jaime Bruna. São Paulo: Cultrix. 1997, $7^{\mathrm{a}}$ edição.

LONGUS. Dafnis y Cloe. Trad. Máximo Brioso Sanches \& Emilio Crespo. Madri: Gredos. 1982, vol.56.

LUCIANO DE SAMÓSATA. Obras. Luciano. Trad. Juan Zaragoza Botella. Madri: Gredos. 1990, vol.138.

PETRÔNIO. Satyricon. Trad. Sandra Bianchet. Belo Horizonte: Crisálida. 2004.

PHILOSTRATUS. Imagines. Trad. Arthur Fairbanks. London: Loeb Classical Library. 1931.

PHOTIUS. Bibliothèque. Texto editado e traduzido por René Henry. Paris: Les Belles Lettres, 1967.

PLATÃo. A República. Trad. Carlos Alberto Nunes. Pará: Editora Universitária UFPA. 2000. $3^{\text {a }}$ edição.

Diálogos I. Trad. Edson Bini. São Paulo: Edipro. 2007.

Parmenides. In: Plato. Trad. Harold N. Fowler. 1992, vol. IV

Philebus. In: Plato. Trad. Harold N. Fowler. London: The Loeb Classical Library. 1995.

Sophist. In: Plato. Trad. Harold N. Fowler. London: The Loeb Classical Library. 1952.

Theaetetus. In: Trad. Harold N. Fowler. London: The Loeb Classical Library. 1952.

QUINTILIAN. The Institutio Oratoria. Trad. H. E. Butler. London: Loeb Classical Library. 1979-89, pt. I-IV.

SALÚSTIO. A Conjuração de Catilina / A Guerra de Jugurta. Trad. Antonio S.Mendonça. Petrópolis: Vozes, 1990.

Conjuration de Catilina. Guerre de Jugurtha. Texte editado por B. Ornstein. Trad. J. Roman. Paris: Belles Lettres. 1924.

SEXTUS EMPIRICUS. Outlines of Pyrrhonism. Trad. R.G. Bury. London: Loeb Classical Library. 1993.

Library. 1997.

Against the Logicians. Trad. R.G. Bury. London: Loeb Classical 
Against the Physicists. Against the Ethicists. Trad. R.G. Bury. London: Loeb Classical Library. 1997.

Against the Professors. Trad. R.G. Bury. London: Loeb Classical Library. 1987.

SUETÔNIO. O Divino Júlio. Trad. Antonio S. Mendonça. In: Vidas de César. São Paulo: Estação Liberdade. 2007.

The Lives of the Caesars. Trad. J. C. Rolfe. London: Loeb Classical Library.1989, vol.I

TEÓN, HERMÓGENES, AFTONIO. Ejercicios de Retórica. Trad. Maria Dolores Madri: Gredos. 1991.

THEON, A. Progymnasmata. Texto editado e traduzido por Michel Patillon \& Giancarlo Bolognesi. Paris: Belles Lettres, 1997.

TUCÍDIDES. História da Guerra do Peloponeso Reche Martinez. Trad. Mário da Gama Kury. Brasília: Universidade de Brasília. 1982.

VIRGÍLIO. Eneida. Trad. Carlos Alberto Nunes. Brasília: EDUNB, 1981.

Eneida. Trad. Odorico Mendes. São Paulo: Ateliê/ Campinas: Editora da Unicamp. 2005.

Ouevres. Énéide. Texto editado por Henri Goelzer. Trad. André Bellessort. Paris: Les Belles Lettres. 1946, vol.III.

Ouevres. Énéide. Texto editado por René Durand. Trad. André Bellessort. Paris: Les Belles Lettres. 1946, vol.IV. 


\section{REFERÊNCIAS MODERNAS}

AMBROSIO, R. De Rationibus Exordiedi. Os princípios da história em Roma. São Paulo: Humanitas/ Fapesp. 2005.

ANDERSON, G. The Second Sophistic. A Cultural Phenomenon in the Roman Empire. New York: Routledge. 1993.

BARNOUW, J. Propositional Perception. Oxford: University Press of America. 2002.

BARTSCH, S. "Ars and the Man: The Politics of Art in Virgil's Aeneid". In: Classical Philology. 1998, vol.93, pp.322-42.

BEAJOUR, M. "Some Paradoxes of Description". In: Yale French Studies. 1981, n61, pp. 27-59.

BECKER, A. S. "Reading Poetry through a Distant Lens: Ecphrasis, Ancient Greek Rhetoricians, and the Pseudo-Hesiodic 'Shield of Heracles' ". In: The American Journal of Philology. 1992, vol.113.

BRUN, J. O Epicurismo. Trad. Rui Pacheco. Lisboa: Edições 70. 1959.

O Estoicismo. Trad. João Amado. Lisboa: Edições 70. 1986.

BENEDIKSTSON, D. T. "Phantasia". In: Literature and the visual arts in Ancient Greece and Rome. Universe of Oklahoma Press: 2000.

BOYD, B.W. "Virtutes Effeminata and Sallust's Sempronia". In: Transactions of the American Philological Association. 1987, vol.117, pp.183-201.

BYRE, C. "Narration, Description and Theme in the Shield of Achilles". In: The Classical Journal. 1992, vol. 88, nº1, pp. 33-42.

CASSIN, B. "Descompartimentar os gêneros". In: O Efeito Sofístico. Trad. A.L. de Oliveira \& M.C.F. Ferraz. São Paulo: Editora 34. 2005, 211-62.

CAMPANHOLO, P. de O. Os comentários de Sérvio Honorato ao "Canto VI" da Eneida. São Paulo: USP. 2008 (Dissertação de Mestrado).

CHINN, C.M. "Before Your Very Eyes: Pliny Epistulae 5.6 and the Ancient Theory of Ekphrasis". In: Classical Philology. 2007, 102, pp.265-80.

CONTE, G. B. Genres and Readers. Trad. Glenn W. Most. London: Johns Hopkins University Press. 1994.

DANTO, A.C. "Depiction and Description". In: Philosophy and Phenomenological Research. 1982, vol. 43, nº1, pp. 1-19.

FOWLER, D. P. "Narrate and Describe: The Problem of Ekphrasis". In: The Journal of Roman Studies. 1991, vol.81, pp.25-35.

FOWLER, B.H. "Skenographia, Skiagraphia, and Phantasia". In: The Hellenisti Aesthetic. Wisconsin: The Bristol Press. 1989, pp.168-86.

GALE, M. R. "The Shield of Turnus (Aeneid 7.783-92)". In: Greece \& Rome. 1997, vol. $44, \mathrm{n}^{\circ} 2$, pp.176-96.

GINZBURG, C. A Micro-História e Outros Ensaios. Trad. Eurico Castelnuovo \& Carlo Poni. Lisboa: Difel. 1989. 
GRANSDEN, K.W. Virgil Aeneid. Book VIII. Cambridge: Cambridge University Press. 1999.

Virgil's Iliad. An Essay on Epic Narrative. Cambridge: Cambridge University Press. 1984.

GURVAL, R.A. "Caesar's Comet: The Politics and Poetics of an Augustan Myth". In: Memoirs of the American Academy in Rome. 1997, vol. 42, pp. 39-71.

HAMON, P. "Rhetorical Status of Descriptive". Trad. Patricia Baudoin. In: Yale French Studies. 1981, nº61, pp. 1-26.

HANSEN, J. A. “As categorias epidíticas da ekphrasis”. In: Revista USP. 2006, n71.

HEFFERNAN, J.A.W. Museum of Words: The Poetics of Ekphrasis from Homer to Ashbery. Chicago: University of Chicago Press, 1993.

$\operatorname{vol} .22, \mathrm{n}^{\circ} 2$.

"Ekphrasis and Representation". In: New Literary History. 1991,

HOUAISS, A. Grande Dicionário Houaiss da Língua Portuguesa. Rio de Janeiro: Objetiva. 2001.

ILDEFONSE, F. Os Estóicos I. Zenão, Cleantes, Crisipo. Trad. Mauro Pinheiro. São Paulo: Esração Liberdade. 2007.

JACKSON, C.N. "The Latin Epyllion”. IN: Harvard Studies in ClassicalPhilology. 1913, vol. 24.

KIRBY, J. T. “Aristotle on Metaphor”. In: The American Journal of Philology. 1997. Vol. 118, no 4. pp. 517-554.

KOORTBOJIAN, M. "Mimesis or Phantasia? Two Representional Modes in Roman Commemorative Art". In: Classical Antiquity. 2005, vol.24, n², pp.285-311.

KRIEGER, M. Ekphrasis. The Illusion of the Natural Sign. London: The Johns Hopkins University Press. 1992.

LAUSBERG, H. Manual de Retórica Literaria. Trad. R. M. Rosado Fernandes. Lisboa: Fund. Caloust Gulbenkian, 1966, vols.1/ 2.

LEONARDI, Elisa Plattzack “A Memória no De Oratore de Cícero”. In: A Memória na Retórica Latina. São Paulo: FFLCH, 2003.

LESSING. Laocoonte ou Sobre as Fronteiras da Pintura e da Poesia. Trad. de Márcio Seligmann-Silva. São Paulo: Iluminuras. 1998.

LEVY, C. \& PERNOT, L. Dire L'Évidence. Paris: L'Harmattan. 1997.

LIDDELL, H. G. \& alii. A Greek-English Lexicon. Oxford: Clarendon Press. 1996, $9^{\mathrm{a} e d i c ̧ a ̃ o . ~}$

MARTINHO, M. dos Santos. "O monstrum da Arte Poética de Horácio". In: Letras Clássicas, 2000, nº , pp.191-265.

MARTINS, P. "Enéias se reconhece". In: Letras Clássicas. São Paulo: Humanitas, 2005.

"Tropos na Eneida e uma imagem metafórica". In: Martinho dos Santos, Marcos (org.) - $1^{\circ}$ Simpósio de Estudos Clássicos. São Paulo: Humanitas. 2006. pp. 91-118. 
"Polignoto, Páuson, Dionísio e Zêuxis - Uma leitura da pintura antiga clássica grega". [Texto inédito aceito para publicação. Campinas: IEL/UNICAMP. Revista Phaos.]. 2008

"Cicero: The Picturing of a Rhetoric". [Aguarda Referee da The Classical Philology, The University of Chicago: Chicago]. 2010.

Imagem e Poder: Considerações Sobre a Representação de Otávio Augusto. São Paulo: USP. 2003 (Dissertação de Doutorado).

MONROE, E. D. “Concerning Casar's Appearance”. In: The Classical Journal. 1917, vol.12, nº 4 , pp.247-53.

MORGANTI, B. F. "A Morte de Laocoonte e o Gigante Adamastor: a Écfrase em Virgílio e Camões”. In: Nuntius Antiquus. Belo Horizonte: Universidade Federal de Minas Gerais. 2008, n²1, pp.1-13.

NEWMAN, S. “Aristotle's Notion of 'Bringing-Before-the-Eyes': Its Contibutionss to Aristotelian and Contemporary Conceptualizations of Metaphor, Style, and Audience". In: Rhetorica, 20/1.2002, pp. 1-23.

PINEDA, V.. "La Invención de la Écfrasis". In: VV. AA., Homenaje a la Profesora Carmen Pérez Romero. Universidad de Extremadura. Facultad de Filosofía y Letras. 2000.pp. 251-69

ROSSI, L. E. "I Generi Letterari e le Loro Leggi Scritte e Non Scritte nelle Letterature Classiche". In: Bulletin of the Institute of Classical Studies, 1971, nº18, pp.69-94.

SARAIVA F. R. dos Santos. Novíssimo Dicionário Latino-Português. Rio de Janeiro: Livraria Garnier. 2000, $11^{\text {a } e d i c ̧ a ̃ o . ~}$

SILVERMAN, A. "Plato on Phantasia". In: Classical Antiquity. 1991, vol.10, n¹.

TAPLIN, O. "The Shield of Achilles within the 'Iliad"”. In: Greece \& Rome. 1980, vol.27, pp.1-21.

TRIMPI, W. "Horace's Vt pictura poesis: The Argument for Stylistic Decorum". In: Traditio. Nova York: Fordham University Press. 1978, vol.34, pp. 29-73.

"The Early Metaphorical Uses of Skiagraphia and Skenographia". In: Traditio. Nova York: Fordham University Press. 1978, vol.34, pp. 404-13.

WALKER, A. D. "Enargeia and the Spectator in Greek Historiography". In: Transactions of the American Philological Association. 1993, vol. 123, pp.353377.

WATSON, G. "The Concept of 'Phantasia' from the Late Hellenistic Period to Early Neoplatonism". In: Rise and Decline of the Roman World. Berlin/ New York: Walter de Gruyter. 1994. Parte II, pp.4765-4810.

WEBB, R. "The Aesthetics of Sacred Space: Narrative, Metaphor, and Motion in 'Ekphraseis' of Church Buildings". In: Dumbarton Oaks Papers. 1999, vol.53, pp.59-74.

Ekphrasis, Imagination and Persuasion in Ancient Rhetorical Theory and Practice. Surrey: Ashgate. 2009.

WHEELER, Arthur Leslie. “Tradition in Epithalamium”. In: The American Journal of Philology, 1930, vol.51, n³. 
WILLIAMS, R. D. “The Pictures on Dido's Temple”. In: The Classical Quarterly, vol.10, n² pp. 145-151. Cf. pp.148.

YACOBI, T. "Pictorial Models and Narrative Ekphrasis". In: Poetics Today. 1995, vol.16, nº 4 , pp.599-649.

YATES, F.A. A Arte da Memória. Trad. Flavia Bancher. Campinas: Unicamp. 2007. 